\title{
Ground-Water Resources \\ of the Wind River \\ Indian Reservation \\ Wyoming
}

GEOLOGICAL SURVEY WATER-SUPPLY PAPER 1576-I

Prepared as part of the program of the Department of the Interior for development of the Missouri River basin

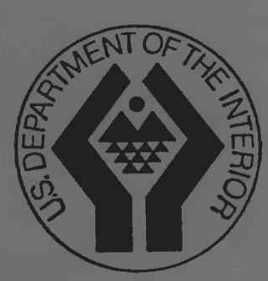




\section{Ground-Water Resources of the Wind River Indian Reservation}

\section{Wyoming}

By LAURENCE J. McGREEVY, WARREN G. HODSON, and SAMUEL J. RUCKER IV WATER SUPPLY OF INDIAN RESERVATIONS

GEOLOGICAL SURVEY WATER-SUPPLY PAPER 1576-I

Prepared as part of the program of the Department of the Interior for development of the Missouri River basin

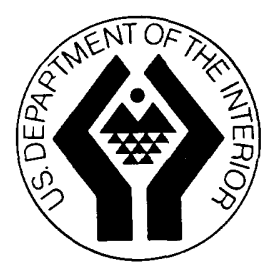




\title{
UNITED STATES DEPARTMENT OF THE INTERICR
}

STEWART L. UDALL, Secretary

\author{
GEOLOGIGAL SURVEY
}

William T. Pecora, Director

For sale by the Superintendent of Documents, U.S. Government Printing O fice Washington, D.C. 20402 


\section{CONTENTS}

Page

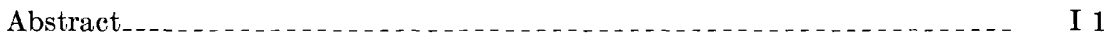

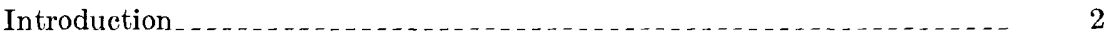

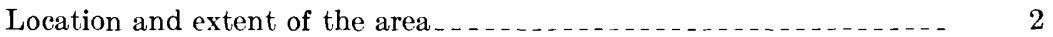

Purpose and scope of the investigation _._.

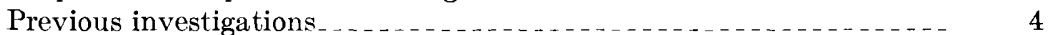

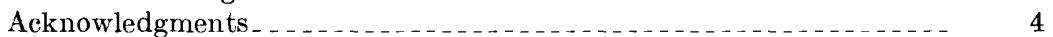

Well-numbering system _................................... 4

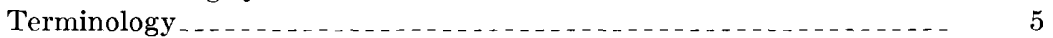

Geographic setting

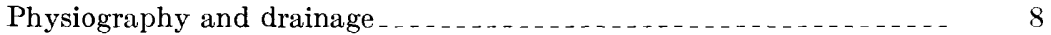

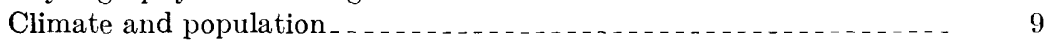

Ownership of the land

Present development of ground water

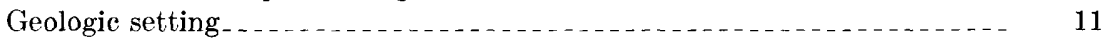

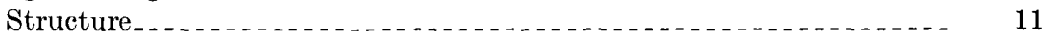

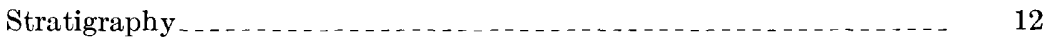

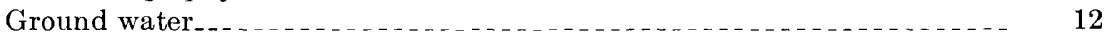

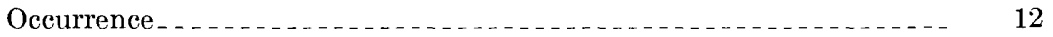

Recharge and discharge $\ldots \ldots \ldots \ldots \ldots \ldots$

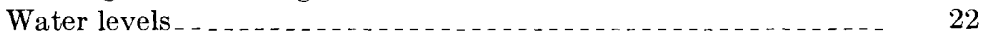

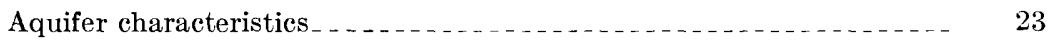

Wind River Formation................................. 25

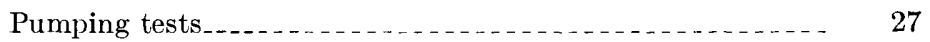

Specific-capacity data 33

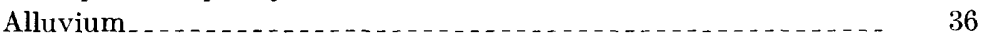

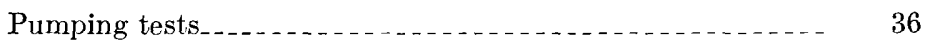

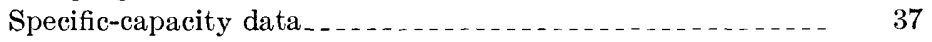

Geologic units in relation to ground water

Precambrian rocks_._. 38

Paleozoic rocks__._. 38

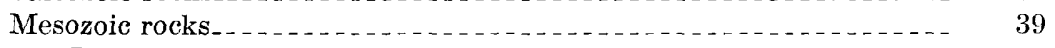

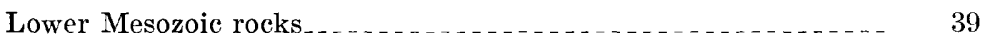

Upper Mesozoic rocks_._. 40

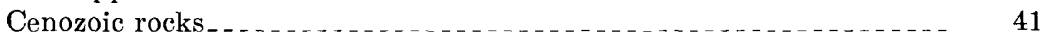

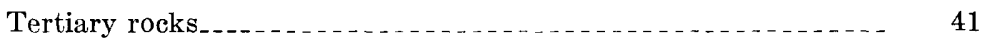

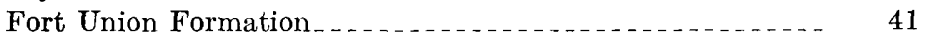

Indian Meadows Formation

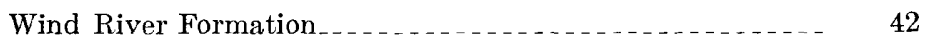

Other Tertiary rocks._. 46

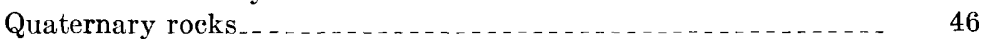

Terrace and pediment deposits_ _................... 46

Slope wash and alluvium_............................. 47

Alluvium of flood plains and related low terraces_..._. $\quad 49$ 
Chemical quality of water.

Water-quality criteria $\ldots \ldots$

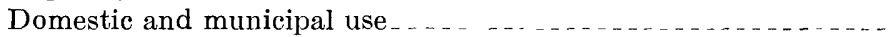

Agricultural use ........

Stock

Irrigation

Industrial use.

Quality of surface water

Quality of ground water

Drainage problems in irrigated areas ... 55

History of irrigation ........... 55

Areas outside the Wind River Irrigation Project. . . _ _ . 56

Areas in the Wind River Irrigation Project. . . . . 56

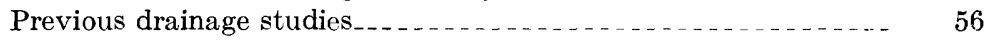

Methods for improving drainage ...................... 57

Classification and evaluation of drainage-problem areas........ 58

Flood plains . . . . . 58

Terraces_..

Underfit-stream valleys ....................

Slopes_...

Transitional areas. . .

Potential use of underground storage 66

Summary _...

Selected references

Tables of basic data $\ldots \ldots \ldots$

Index . . . . . 143

\section{ILLUSTRATIONS}

[Plates in plate volume]

Plate 1. Map showing well locations and chemical quality of ground water.

2. Geologic map.

3. Map and sections showing drainage-problem areas in the Wind River Irrigation Project.

Figure 1. Structural feature map showing the area of this study and areas of related ground-water studies

2. Diagram showing well-numbering system .............

3. Map showing generalized areal distribution of mean annual precipitation

4. Hydrographs of wells showing several types of water-l?vel fluctuations.

5. Hydrograph of well A3-3-21ada2

6. Hydrograph of well A1-4-33ddb comparing the influenee of the Riverton well ficld in 1951 and 1966

7. Sketch showing relation of drawdown, residual drawdown,

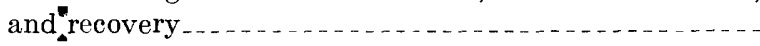


Figures 8-10. Graph of-

8. Adjusted recovery of well A3-6-15bcb.........

9. Adjusted recovery of well D1-4-4cdd

10. Residual drawdown of well D1-5-11ace

11. Histograms of specific capacity per foot of contribution for wells in alluvium and in the Wind River Formation .

12. Graph showing distribution of specific capacity per foot of contribution for wells in alluvium and in the Wind River Formation -

13. Diagrammatic section showing approximate relations of major facies of part of the Wind River Formation.....

14. Sections of alluvium in Kirby Draw

15. Diagram showing classification of water from alluvium for irrigation use

\section{TABLES}

TABLE

1. Generalized section of the geologic units and potential water supply

Page

2. Principal data concerning pumping tests

3. Records of wells and springs

4. Drillers' $\log$ s of wells _ _ _ _ _ _ 85

5. Logs of test holes and test wells _._.

6. Chemical analyses of ground-water samples _ _ _ _ _ 126

7. Chemical analyses of surface-water samples. . . . . . 136 


\title{
WATER SUPPLY OF INDIAN RESERVATIONS
}

\section{GROUND-WATER RESOURCES OF THE WIND RIVER INDIAN RESERVATION, WYOMING}

\author{
By Laurence J. McGreevy, Warren G. Hodson, end \\ SAMUel J. RUCKeR iv
}

\begin{abstract}
The area of this investigation is in the western part of the Wind River Basin and includes parts of the Absaroka, Washakie, Wind River, and Owl Creek Mountains. The purposes of the study were to determine the general hydrologic properties of the rocks in the area and the occurrence and quality cf the water in them. Structurally, the area is a downfolded basin surrounded by upfolded mountain ranges. Igneous and metamorphic rocks of Precambrian age are exposed in the mountains; folded sedimentary rocks representing all geologic periods, except the Silurian, crop out along the margins of the basin; and relatively flat-lying Tertiary rocks are at the surface in the central part of the basin. Surficial sand and gravel deposits of Quaternary age occur along streams and underlie numerous terraces throughout the basin.

The potential yield and quality of water from most rocks in the area are poorly known, but estimates are possible, based on local well data and on data concerning similar rocks in nearby areas. Yields of more than $1,000 \mathrm{gpm}$ are possible from the rocks comprising the Bighorn Dolomite (Ordovician), Darby Formation (Devonian), Madison Limestone (Mississippian), and Tensleep Sandstone (Pennsylvanian). Total dissolved solids in the water range from about 300 to $3,000 \mathrm{ppm}$.

Yields of as much as several hundred gallons per minute are possible from the Nugget Sandstone (Jurassic? and Triassic?). Xields of $20 \mathrm{gpm}$ or more are possible from the Crow Mountain Sandstone (Triassic) and Sundance Formation (Jurassic). Dissolved solids are generally high but are less than 1,000 ppm near outcrops in some locations.

The Cloverly and Morrison (Cretaceous and Jurassic), Mesaverde (Cretaceous) and Lance(?) (Cretaceous) Formations may yield as mucl as several hundred gallons per minute, but most wells in Cretaceous rocks yield less than $20 \mathrm{gpm}$. Dissolved solids generally range from 1,000 to $5,000 \mathrm{ppm}$ but may be higher. In some areas, water with less than $1,000 \mathrm{ppm}$ dissolved sclids may be available from the Cloverly and Morrison Formations.

Tertiary rocks yield a few to several hundred gallons per minute and dissolved solids generally range from 1,000 to $5,000 \mathrm{ppm}$. Wells in the Wind River Formation (Eocene) yield about 1.500 gpm of water having dissolved solids of about $200-5,000 \mathrm{ppm}$.
\end{abstract}


Yields of a few to several hundred gallons per minute are available from alluvium (Quaternary). Dissolved solids range from about 200 tc $\mathbf{5 , 0 0 0} \mathrm{ppm}$.

Many parts of the Wind River Irrigation Project have become waterlogged. The relation of drainage problems to geology and the character and thickness of rocks in the irrigated areas are partly defined by sections drawn on the basis of test drilling. The drainage-problem areas are classified according to geologic similarities into five general groups: flood plains, terraces, underfit-stream valleys, slopes, and transitional areas.

Drainage can be improved by open drains, buried drains, relief wells, and pumped wells or by pumping from sumps or drains. The methods that will be nost successful depend on the local geologic and hydrologic conditions. In several areas, the most effective means of relieving the drainage problem would be to reduce the amount of infiltration of water by lining canals and ditches and by reducing irrigation water applications to the optimun.

Water from underground storage in alluvium could supplement water from surface storage in some areas. A few thousand acre-feet of water per square mile are in storage in some of the alluvium. The use of both surface and underground storage would reduce the need for additional surface-storage facilities and also would alleviate drainage problems in the irrigated areas.

\section{INTRODUCTION}

\section{LOCATION AND EXTENT OF THE AREA}

The area of this investigation consists of about 3,500 square miles in west-central Wyoming and includes most of central and western Fremont County and part of southern Hot Springs County. It is the area within the outer boundary of the Wind River Indian Reservation. The area of the investigation and areas of related ground-water studies are shown in figure 1.

\section{PURPOSE AND SCOPE OF THE INVESTIGATION}

This study was conducted by the U.S. Geological Surrey at the request of the U.S. Bureau of Indian Affairs as a part of the program of the Department of the Interior for development of the Missouri River basin.

The purposes of this investigation were to determine the general hydrologic properties of geologic formations in the area and the occurrence and quality of ground water in them. Of particular need were clata concerning the availability of water for domestic and stock use and data concerning drainage problems in the Wind River Irrigation Project.

Fieldwork for this investigation was carried on during 1965 and 1966. Records of 387 wells in the area were collected and tabulated; water samples were collected from selected wells for chemical analysis. Specific conductances were determined in the field for some waters. Periodic measurements of selected wells were made to observe waterlevel fluctuations. Drillers' logs were collected from local drillers, from 


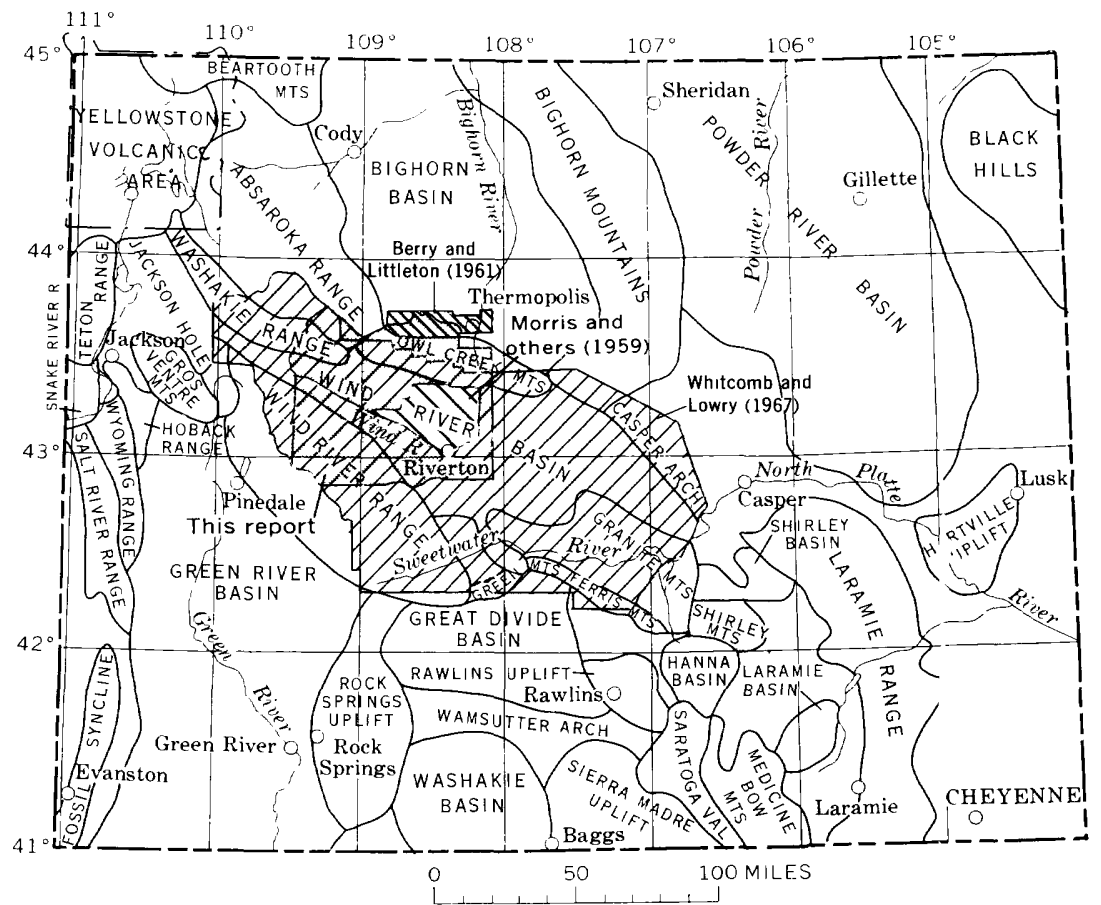

Figure 1.- Structural feature map showing the area of this study and areas of related ground-water studies. Adapted from Love (1961).

the Indian Health Center on the Wind River Indian Reservation, and from the files of the Wyoming State Engineer. Additional subsurface information was obtained from several hundred feet of test augering in 1965 and from about 6,000 feet of test drilling contracted in 1966. The general thickness and character of the alluvium and the relation of the deposits to areas of drainage problems were determined by test drilling in the principal valleys, mostly in the irrigated areas. Additional drilling was done in remote areas of the reservation, previously untested for water, to determine the ground-water potential for the stock-grazing industry. Data collected for previous studies (Morris and others, 1959; Berry and Littleton, 1961) were also used in arriving at the conclusions of the report.

A geologic map was compiled at a scale of $1: 125,000$ from existing geologic maps of the area (pl. 2). The details, purposes, and scales of the existing maps varied considerably and, at the scale of the compilation, all geologic contacts must be considered approximate. Discrepancies in contacts of Quaternary units were minimized by using $71 / 2$-minute topographic maps, aerial photographs, and dats from test drilling. 


\section{PREVIOUS INVESTIGATIONS}

Reports of ground-water studies have been published on the Riverton Irrigation Project (Morris and others, 1959), which includes an area of about 500 square miles between the Wind River and the south flank of the Owl Creek Mountains, and on the Owl Creek \&,rea (Berry and Littleton, 1961), which includes an area of about 250 square miles along the north flank of the Owl Creek Mountains. Little additional fieldwork in these areas was done in conjunction with this investigation. A reconnaissance of the ground-water resources of the Wind River Basin was made by Whitcomb and Lowry (1967). The locations of areas of these previous ground-water investigations are shown in figure 1.

Geologic studies pertinent to this study include reports by Keefer and Van Lieu (1966) on Paleozoic formations in the $\mathrm{V}^{\top}$ ind River Basin; by Keefer (1965a) on the Upper Cretaceous, Paleocene, and Eocene rocks of the Wind River Basin; and by Keefer and Troyer (1964) on the geology of the Shotgun Butte area in the ncrth-central part of the Wind River Indian Reservation. The index map on plate 2 shows the locations of areas of these studies and of areas described by other maps and reports that provide the principal sources of geologic data used in this study. References to other pertinent reports are listed at the end of this report.

\section{ACKNOWLEDGMENTS}

The authors are indebted to well owners and drillers who furnished essential information regarding wells and to the many persons who assisted in the collection of information and in the preparation and review of this report. Special thanks are due John T. Myers, of the U.S. Public Health Service, and William L. Benjamin and the late John Jolley, of the U.S. Bureau of Indian Affairs, who gave assistance in obtaining data.

\section{WELL-NUMBERING SYSTEM}

Wells, springs, and test holes referred to in this report are numbered according to their location within the Federal system of land subdivision. Each number shows the location by township, range, section, and location within the section. The uppercase letter that begins the number designates the quadrant of the Wind River Meridian and Base Line system. The quadrants are lettered A, B, C, and D in a counterclockwise direction beginning with $\mathrm{A}$ in the northeast quadrant. The first numeral denotes the township; the second numeral, the range; and the third numeral, the section in which the well or test hole is located. The lowercase letters after the section number indicste the loca- 
tion within the section as follows: The first letter denotes the quarter section; the second letter, the quarter-quarter section; and the third letter, if used, the quarter-quarter-quarter section (10-acre tract). The subdivisions of the sections are lettered $a, b, c$, and $d$ in a counterclockwise direction beginning with " $\mathrm{a}$ " in the northeast quarter. If more than one well is listed in the smallest subdivision used, they are differentiated by consecutive numerals (starting with 1) that are added to the well or test-hole number. For example, well D1-2-15abc is in the SW1/4 NW1/4 NE1/4 sec. 15, T. 1 S., R. 2 E. (fig. 2).

\section{TERMINOLOGY}

Many terms and abbreviations that are used in this report may be unfamiliar to the reader, or the terms may be used in other reports in a less restricted or in a slightly different sense than they are used in this report. The following definitions should clarify the intended meanings.

Aquifer. A rock formation, bed, or zone that will yield water to wells or springs. If one or more water-bearing units are hydraulically connected, these units may be considered as one aquifer. An aquifer may be confined (artesian) or unconfined (water table). A confined aquifer is overlain by relatively impermeable rock, and the water in a well will rise above the top of the aquifer. In an unconfined aquifer, the level to which water will rise in a well is below the top of the aquifer.

Alluvium. Deposits that have been transported and deposited by streams. Alluvium, as herein used, is restricted to deposits of Quaternary age that underlie the flood plains and terraces. Allurium grades into slope wash along the valley sides; deposits that are predominantly stream laid are referred to as alluvium.

Clastic rock. A rock composed of fragments of preexisting rock. Most clastic rocks are shale, sandstone, conglomerate, clay, silt, sand, or gravel.

Coefficient of storage. The coefficient of storage of an aquifer is defined as the rolume of water released from or taken into storage per unit surface area of the aquifer per unit change in the component of head normal to that surface (Ferris and others, 1962).

Colluvial deposits. Slope wash and material transported principally by gravity.

Cuesta. A ridge with one long and gentle slope and one relatively steep slope.

Dissolved solids. Minerals in solution in water. As used in this report, it refers to the total concentration of dissolved solids in water.

gpd. Abbreriation of gallons per day. 


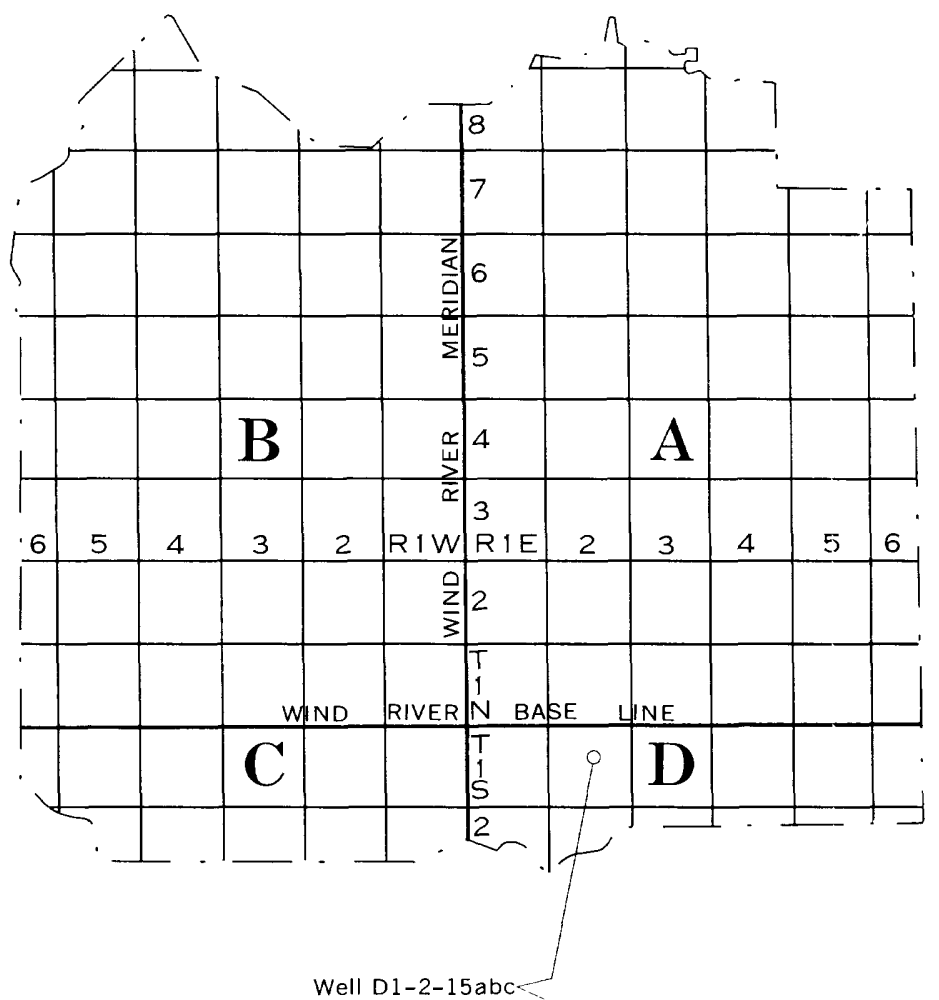

Well D1-2-15abces

\begin{tabular}{|c|c|c|c|c|c|c|c|c|c|}
\hline \multicolumn{6}{|c|}{ R. 2 E. } & & \multicolumn{3}{|c|}{ Sec. 15} \\
\hline 6 & 5 & 4 & 3 & 2 & 1 & & 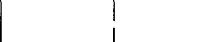 & $b$ a & $a$ \\
\hline 7 & 8 & 9 & 10 & 11 & 12 & & & $-1-$ & $\ldots$ \\
\hline 18 & 17 & 16 & 15 & 14 & 13 & $\mathrm{~T}$. & & c & d \\
\hline 19 & 20 & 21 & 22 & 23 & 24 & $\mathrm{~S}$ & $i$ & I & \\
\hline 30 & 29 & 28 & 27 & 26 & 25 & & $--c-$ & $--d$ & - \\
\hline 31 & 32 & 33 & 34 & 35 & 36 & & 1 & & \\
\hline
\end{tabular}

Figure 2.-Well-numbering system.

gpm. Abbreviation of gallons per minute.

Infiltration. The flow or seepage of water into rocks or soil through pores or small openings. 
Intermittent stream. $\Lambda$ stream that flows only part of the time.

ppm. Abbreviation of parts per million; the unit of expression for the concentration of dissolved material in water. One part per million is one unit weight of dissolved material per million unit weights of water.

Perennial stream. A stream that flows all the time.

Permeability. The capacity of materials to transmit water. The measure of permeability used in this report is the field coefficient of permeability, which is defined as the rate of flow of water in gallons per day through a cross-sectional area of 1 square foot under a hydraulic gradient of 1 foot per foot at the prevailing water temperature (Ferris and others, 1962). It is expressed in gallons per day per square foot $\left(\mathrm{gpd} / \mathrm{ft}^{2}\right)$.

Physiography. As used in this report, it is restricted to description of landforms, the topographic features.

Recharge. The process by which water moves into an cquifer, or the amount of water that moves into an aquifer.

Specific capacity. The amount of water discharged from a well per unit of drawdown. It is expressed as gallons per minute per foot of drawdown $(\mathrm{gpm} / \mathrm{ft})$.

Specific conductance. A measure of the ability of a water to conduct electricity. Specific conductance is expressed in mhos (reciprocal of ohms) per centimeter times $10^{6}$ (micromhos per centimeter) and is adjusted to a standard temperature of $25^{\circ} \mathrm{C}$. Specific conductance is related to the amount of dissolved solids in water, but the relation depends on the particular minerals present. The ratio of total dissolved solids (in parts per million) to specific conductance (in micromhos per centimeter at $25^{\circ} \mathrm{C}$ ) ranges from about $1 / 2: 1$ to $1: 1$, but is usually nearer $2 / 3: 1$. Specific conductance is easily moasured in the field and provides a quick estimate of the dissolved solids.

Specific yield. The ratio of the volume of water that will drain by gravity from a saturated material to the volume of the material. It is expressed as a percentage

$$
\left(\frac{\text { volume of water }}{\text { volume of material }} \times 100\right) \text {. }
$$

Transmissibility. The capacity of the full saturated thickness of an aquifer to transmit water. The measure of transmissibility used in this report is the coeffcient of transmissibility, which is defined as the rate of flow of water, at the prevailing water temperature, in gallons per day, through a vertical strip of the aquifer 1 foot wide extending the full saturated height of the acquifer under a hydraulic gradient of 1 foot per foot (Ferris and others, 1962). It is expressed in gallons per day per foot $(\mathrm{gpd} / \mathrm{ft})$. The coefficient of transmissibility is equal to 
the product of the saturated thickness times the field corfficient of permeability.

Transpiration. The process by which water moves from living plants to the atmosphere.

Underfit stream. A stream that occupies a valley that was formed by a much larger stream. Dury $(1964 a, b)$ discusses underfit streams.

Water table. The top of the zone of saturation in an unconfined aquifer.

\section{GEOGRAPHIC SETTING}

\section{PHYSIOGRAPHY AND DRAINAGE}

The Wind River Indian Reservation is in the western part of the Wind River Basin, which is a structural and topographic basin typical of the Rocky Mountain physiographic system. The southwestern boundary of the reservation extends along the crest of the Wind River Mountains; the northern part of the reservation includes parts of the Washakie, Absaroka, and Owl Creek Mountains. The Wind River Basin is a large structural basin that approximately coincides with the topographic basin. Altitudes range from about 4,400 feet at the north end of the Wind River Canyon to more than 13,000 feet on the crest of the Wind River Mountains. In most of the central part of the basin, the altitude is between 4,800 and 6,000 feet. Upturned rocks of Paleozoic and Mesozoic age form distinct cuestas and hogbacks along the mountain fronts, and, in the central part of the basin, nearly horizontal rocks of Tertiary age form generally broad valleys and prominent gravel-capped mesas and buttes. The Wind River valley is relatively deep compared to most other stream valleys in the basin, and high bluffs border the river in many places. Mesas and buttes form drainage divides between the smaller streams.

The Wind River is the master stream in the area, originating in the Absaroka Mountains in the northwest corner of the Wind River Basin. The Wind River flows southeastward parallel to the Wind River Mountains to its confluence with the Little Wind River near Riverton where it turns northward, eventually flowing through the Wind River Canyon into the Bighorn Basin where the river is called the Bighorn River. The larger tributaries to the Wind River head in the Wind River and Absaroka Mountains. The principal tributaries, within the area of this investigation, are Bull Lake Creek, the Little Wind River, and the Popo Agie River in the southern part of the area; Crow Creek in the northwestern part; and Fivemile Creek and Muddy Creek in the central part. 


\section{CLIMATE AND POPULATION}

The climate ranges from humid in the Wind River and Owl Creek Mountains to arid in the central part of the area. Mean annual temperature at Riverton for the period of reference, $1931-60$, is $43.5^{\circ} \mathrm{F}$. Wide ranges in seasonal temperatures are common-winter temperatures commonly dropping far below $0^{\circ} \mathrm{F}$, and summer temperatures frequently exceeding $100^{\circ} \mathrm{F}$. Mean annual precipitation at Rirerton for the period 1931-60 was 8.79 inches. Annual precipitation ranged from 4.85 to 14.74 inches. Mean annual precipitation at Lander, just south of the report area at the edge of the Wind River Mountains, was 13.58 inches. The generalized areal distribution of mean annual precipitation on the reservation has been mapped by the U.S. Bureau of Indian Affairs (1962) and is shown in figure 3.

Much of the population is rural. Riverton, the largest town in the area, has a population of about 6,900. The Wind River Reservation is the home of more than 3,000 Shoshone and Arapahoe Indians.

\section{OWNERSHIP OF THE LAND}

Ownership of the lands of the report area has evolved from historical events discussed in Duntsch (1965), Gerharz (1949), U.S. Bureau of Indian Affairs (1962), and U.S. Bureau of Reclamation (1950). The first non-Indians settled in the Wind River Basin in the early $1860^{\circ} \mathrm{s}$. Treaties of 1863 and 1868 with the Shoshone Indians established the Wind River Reserration with boundaries nearly identical to the area of this study. In 1877 the Federal Government, obtained permission from the Shoshone Tribe to bring a tribe of Northern Arapahoe to the reservation, temporarily, until one for tl-s Arapahoes could be established. The reservation was never established and the Arapahoe and Shoshone Indians now share the Wind River Reservation.

In 1904 the land north of the Wind River and the land southeast of the Popo Agie River, which together consisted of about two-thirds of the reservation, were ceded to the United States. The caded land was opened to homesteading in 1906, and the townsite of Riverton was established. Part of the ceded land was repurchased by the tribes, and part was restored to tribal ownership by legislation; however, some is still privately owned by non-Indians. Most of the land within the outer boundary of the reserration, except for the Riverton Irrigation Project and Boysen Reservoir withdrawal areas (pl. 3), is owned by the tribes. 


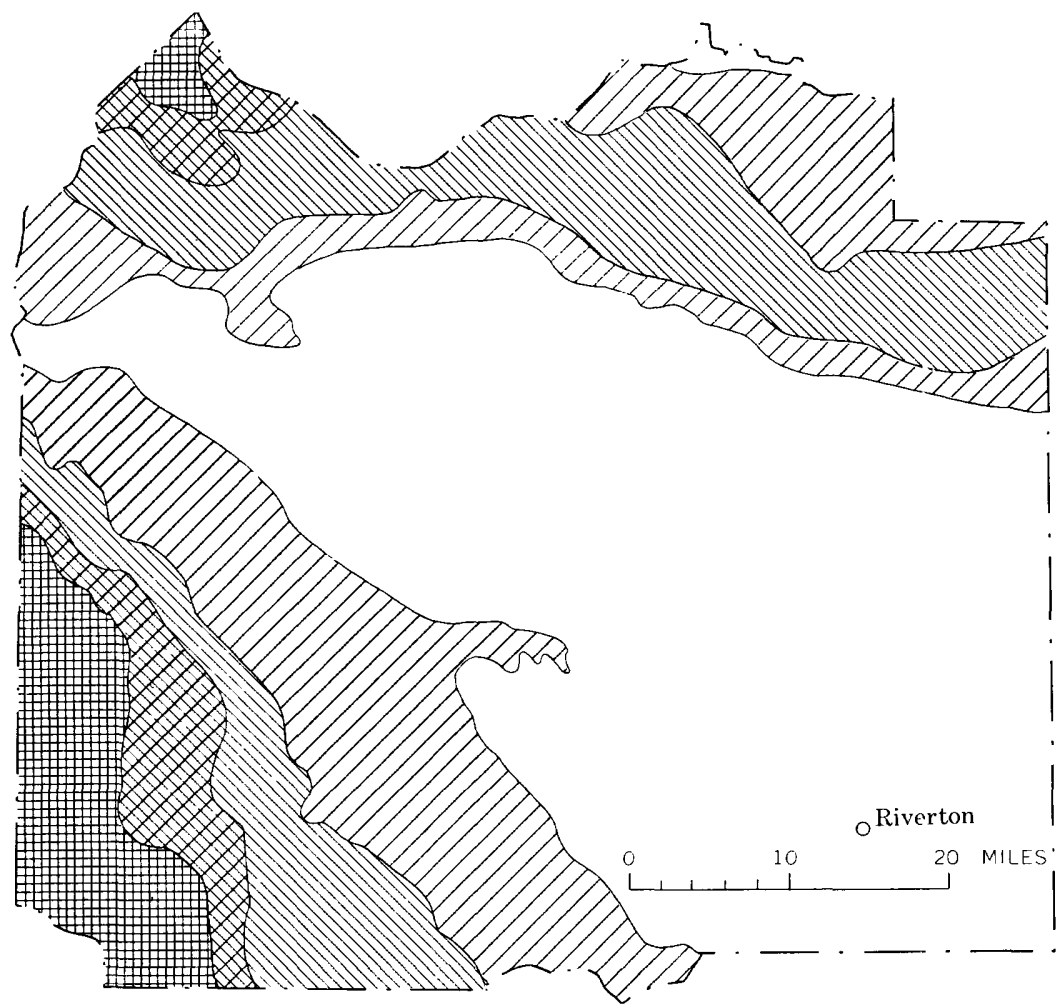

EXPLANATION
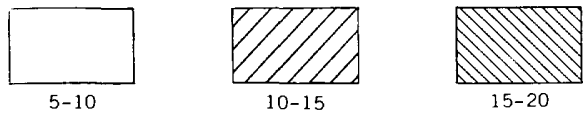

$15-20$
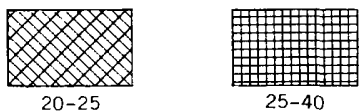

Mean annual precıpitation, in Inches

Figure 3.-Generalized areal distribution of mean annual precipitation. Adapted from U.S. Bureau of Indian Affairs (1962).

\section{PRESENT DEVELOPMENT OF GROUND WATER}

Development of ground water has been principally for stock watering and for domestic and public supplies. Privately owned wells furnish water to oil fields and a few industries at Riverton. In the Owl Creek valley, irrigation water from streams is suppleme'nted with water from wells, but in the rest of the reservation, irrigation depends entirely on surface supplies.

Most wells are in the area of the Riverton Irrigation Project (pl. 3) and in the areas along the Wind and Little Wind Rivers. Tixcept for test drilling that was done for this study, many remote areas are virtually untested for water. Locations of wells and data concerning the chemical quality of water from the wells are shown on plate 1. 
Domestic and public supplies generally utilize ground water, al. though surface water is used at some localities. Municipally owned wells furnish water to Riverton, Pavillion, Hudson, and Shoshoni. The wells furnishing water to Hudson are south of the reservation boundary (Whitcomb and Lowry, 1967); Shoshoni, 3 miles east of the reservation boundary, is supplied by wells inside the boundary. An infiltration gallery in the bed of the South Fork Little Wind Rirer supplies water to Fort Washakie. Mill Creek School, 3 miles south of Ethete, and the community of Ethete are supplied by separate infiltration galleries in the bed of the Little Wind River near Ethete. Cooperative community wells are being considered to serve homes in the Arapahoe area. In other communities and in rural areas, homes depend on individually owned wells.

\section{GEOLOGIC SETTING}

\section{STRUCTURE}

The structural framework of the area consists of a downfolded basin bounded on the north and southwest by upfolded and faulted mountain ranges. Vertical structural displacement is more than 30,000 feet between the basin and the mountains. Keefer (1965a) gives a detailed account of the structural development of the area during Laramide deformation. Major structures and generalized structure contours are shown on plate 2. Two deep structural troughs are separated by a central anticlinal structure which trends northwestward through the basin approximately parallel to the Wind River Mountains. Major oil fields in the area are on the central anticlinal structure and on a parallel structure of lesser magnitude to the northeast.

Formation of the basin began in Late Cretaceous time and continued into Eocene time. As the basin subsided in relation to the bordering highlands, sediments accumulated in the depression. Along the margins of the basin, the rocks of Paleozoic and Mesozoic s.ge dip basinward at angles ranging from about $10^{\circ}$ on the flanks of the TVind River Mountains to vertical or overturned along the northern mountains. Rocks of early Eocene age, which occur at the surface in much of the basin, are nearly flat lying in most of the area. Dips measured in the lower Eocene Wind River Formation (pl. 2) indicate that the structure of this formation is extremely subdued, but corresponds to the structure of the underlying rocks. The subdued structure may be partly depositional, but some deformation of the formation has occurred along the margins of the basin and on the central anticlinal structure. 


\section{STRATIGRAPHY}

Igneous and metamorphic rocks of Precambrian age comprise the core of the mountain ranges and underlie sedimentary rocks within the basin. Sedimentary rocks have a maximum thickness of more than 40,000 feet and represent all geologic periods except the Silurian. Descriptions of sedimentary units are given in table 1, and the relation of these units to ground water are discussed in the table and in another section. Outcrop areas of the rocks are shown on the geologic map (pl. 2).

\section{GROUND WATER}

\section{OCCURRENCE}

Ground water occurs in rocks in the open spaces between grains, in fractures, or in solution openings. The water is derived from precipitation either directly or from seepage of surface waters. Water moves through the rocks from recharge areas to discharge areas at rates dependent on the gradient and the permeability of the rocks. Principles of occurrence are described in Meinzer (1923a) and in E. E. Johnson, Inc. (1966).

\section{RECHARGE AND DISCHARGE}

Rocks older than the Wind River Formation are recharged primarily in their outcrop areas by streams and by direct infiltration of precipitation; some morement of water between formations probably occurs where the rocks are buried. Most discharge from the rocks is through springs where the rocks have been cut into by streams. Discharge to wells is minor because few wells tap these rocks.

The Wind River Formation crops out, or is thinly covered by alluvium or slope wash, in most of the basin. In their upper reaches, streams crossing the formation generally contribute water to it. In their lower reaches, many of these streams drain parts of the formation. Some water-bearing rocks of the formation are at higher altitudes than nearby streams. Water in these rocks comes from direct infiltration of precipitation or, in some areas, from irrigation.

Hundreds of wells tap the Wind River Formation, but most wells discharge only a small amount of water. Almost 500 million gallons of water per year are withdrawn from the formation by wells in the Riverton well field. Figures are not arailable for other wells, but the total withdrawal from the formation by wells, including those in the Riverton well field, is estimated at $700-800$ million gallons per year.

Alluvium is recharged primarily from streams and irrigation, but some water is derived from direct infiltration of precipitation. Water in alluvium adjacent to the streams moves to or from the streams, de- 
WIND RIVER INDIAN RESERVATION, WYOMING

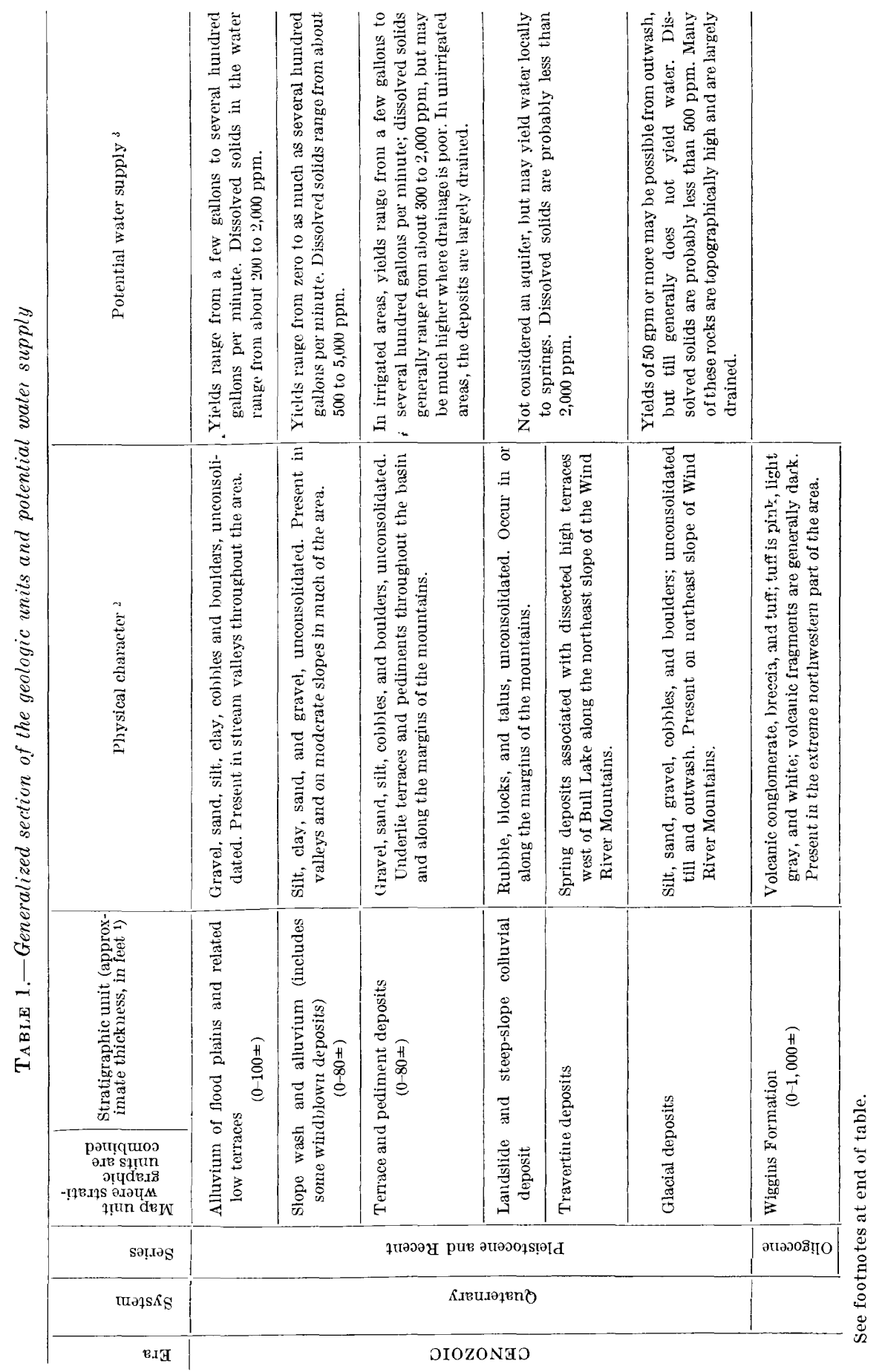




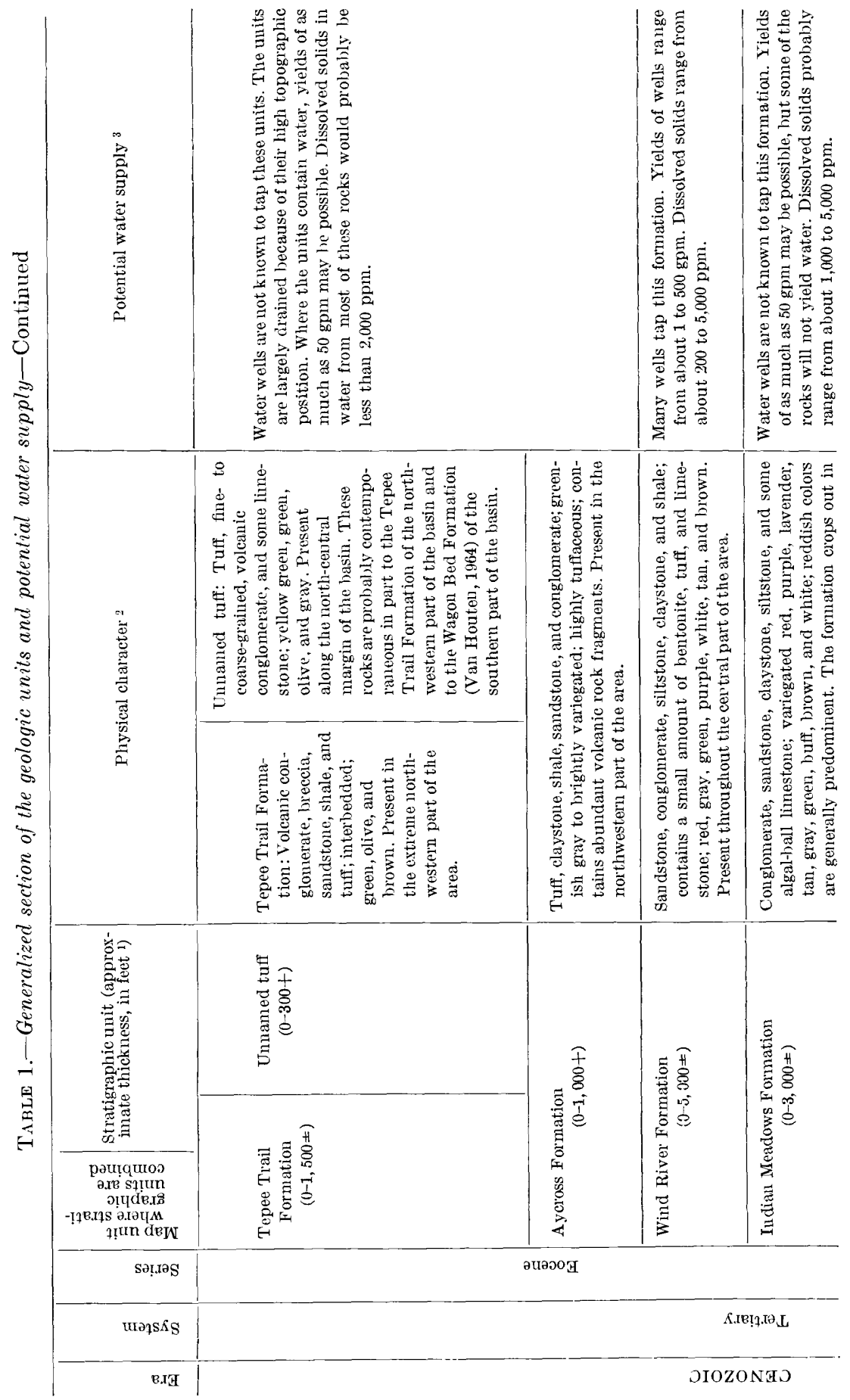




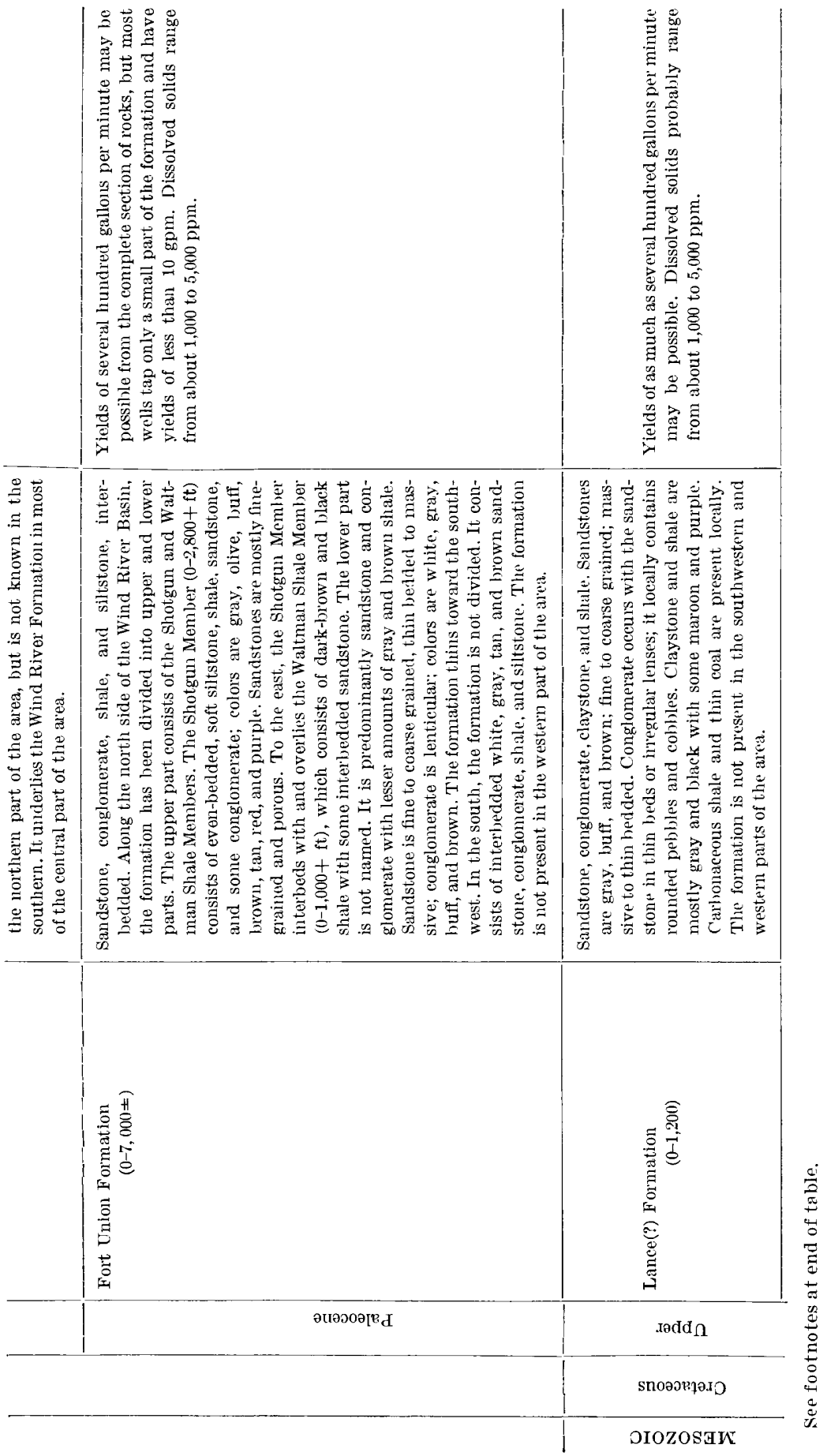




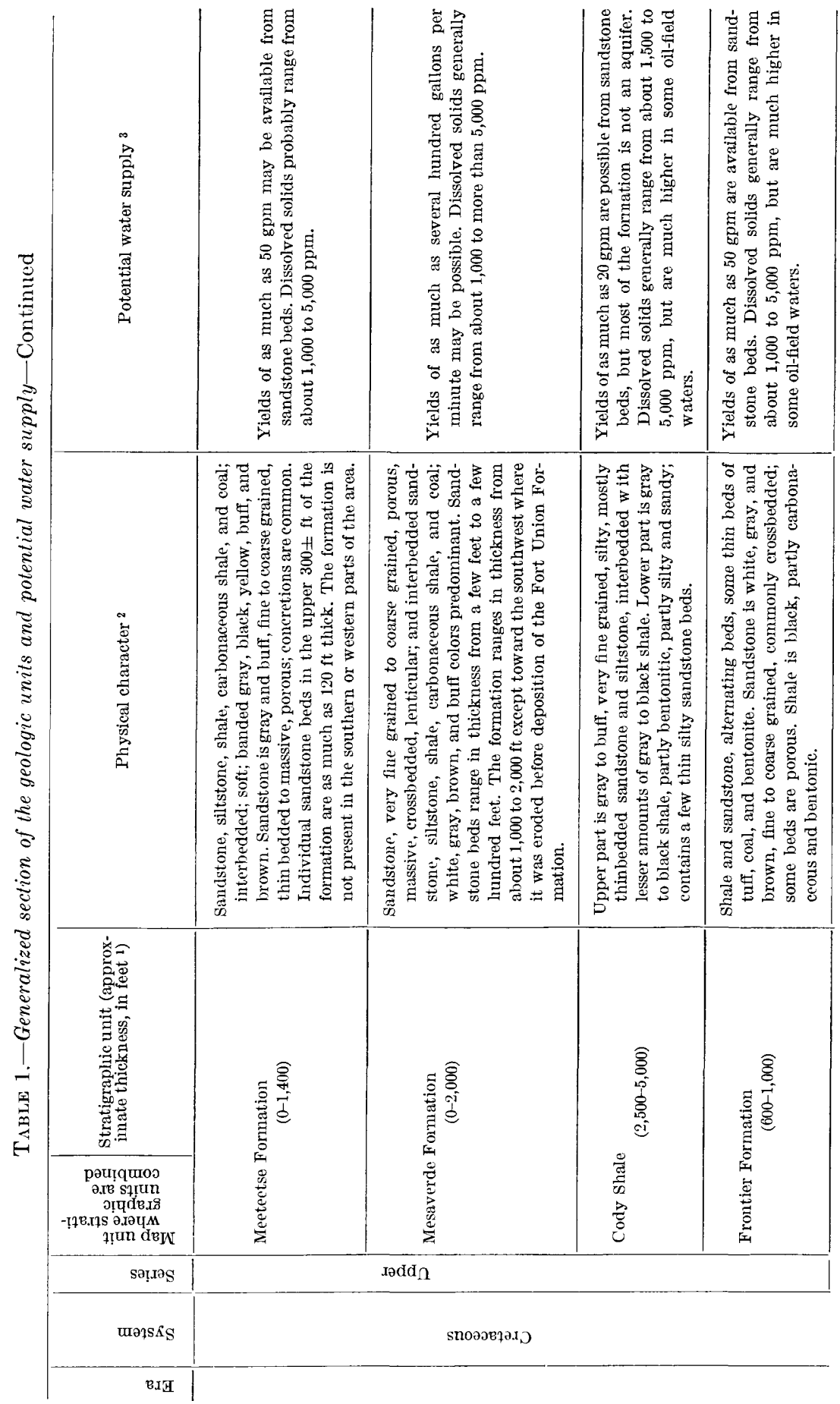




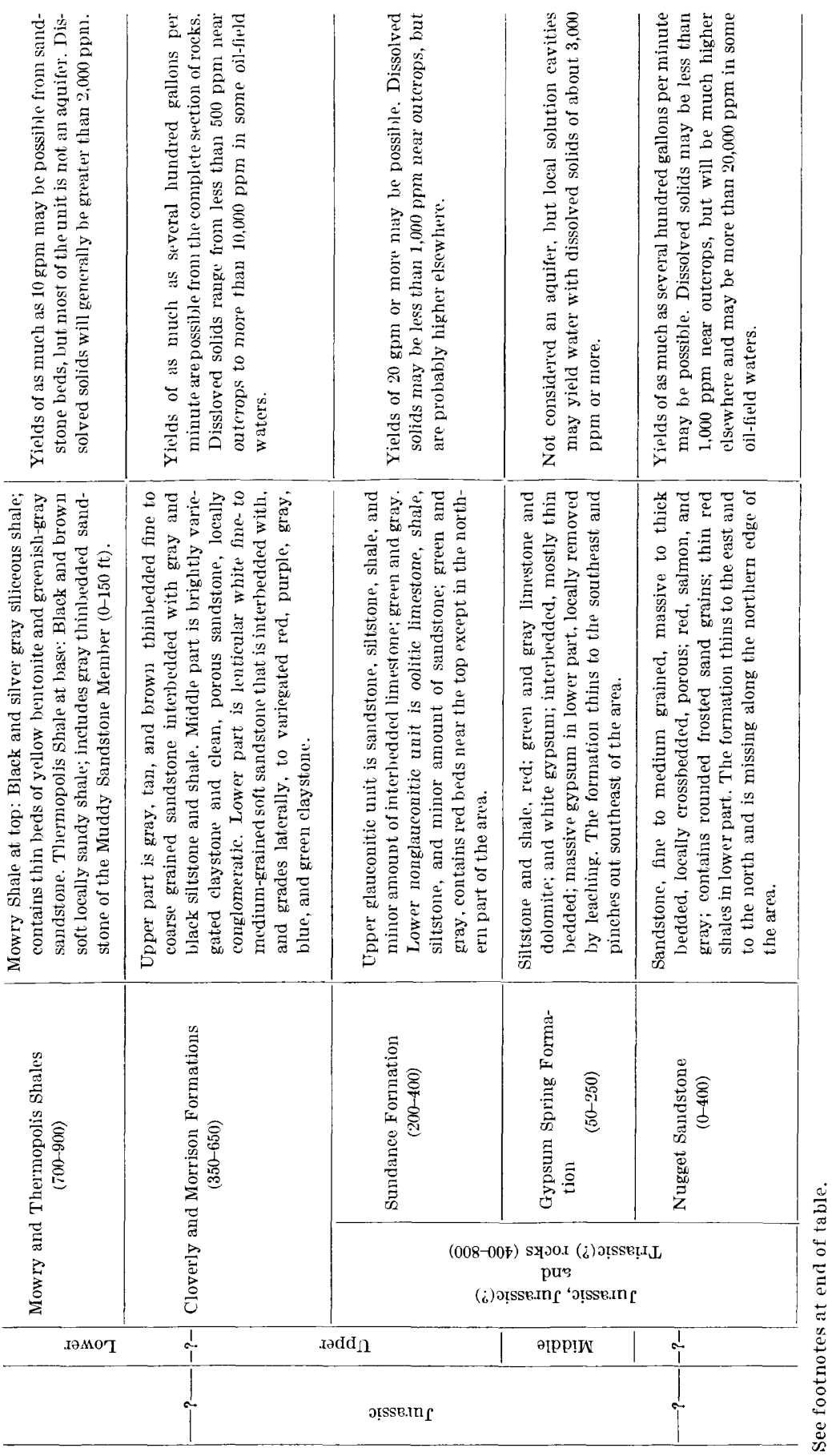




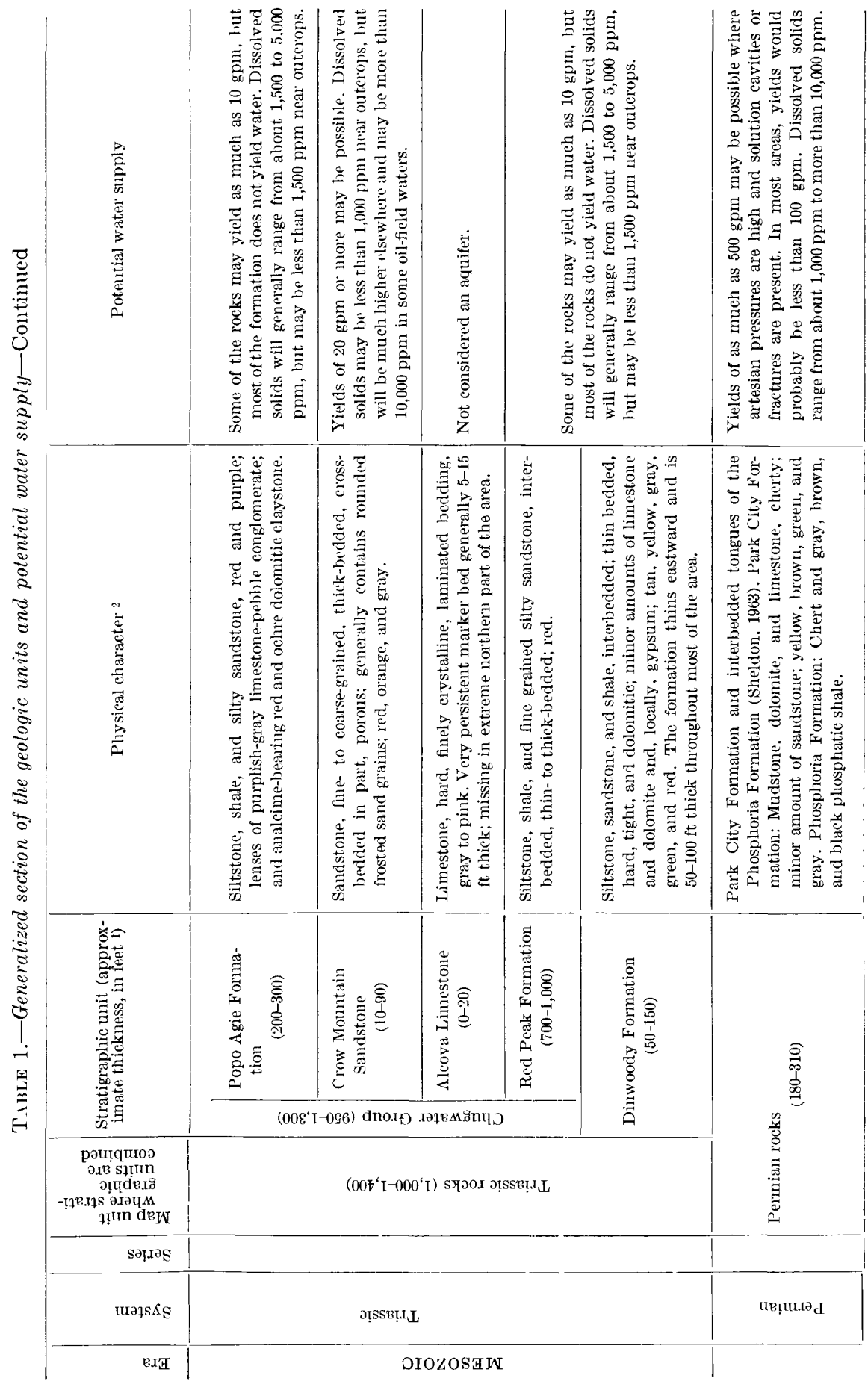




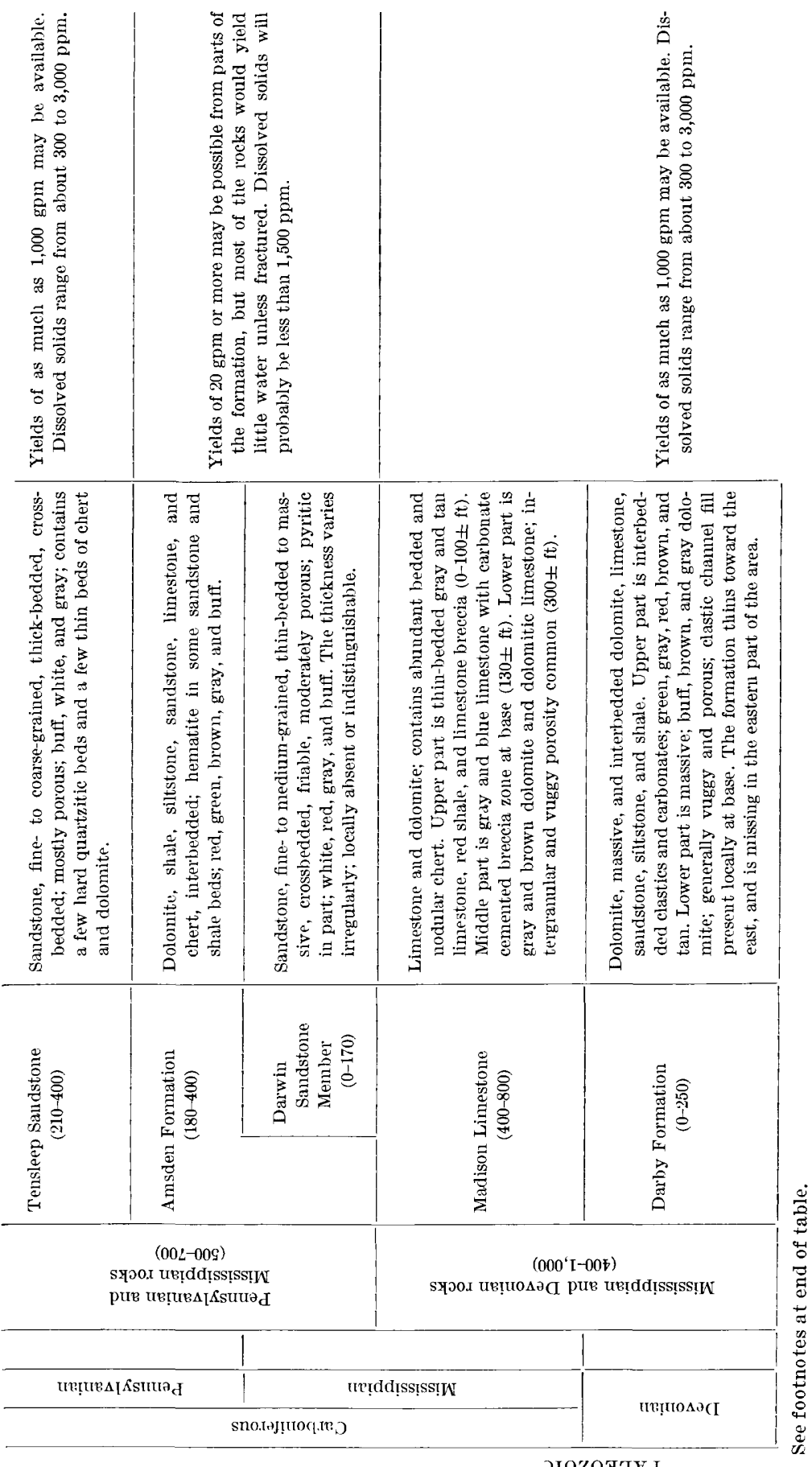

गIOZOA'TVI 


\begin{tabular}{|c|c|c|c|c|}
\hline 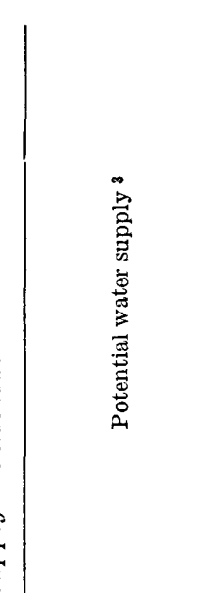 & & \multicolumn{2}{|c|}{ 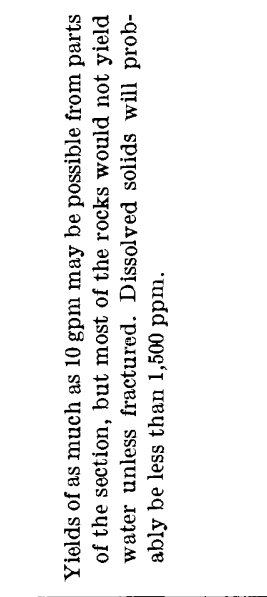 } & 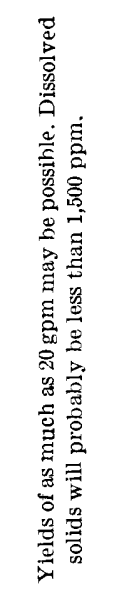 \\
\hline 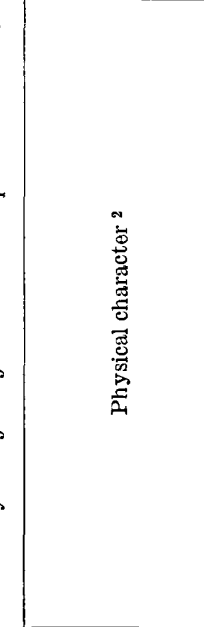 & 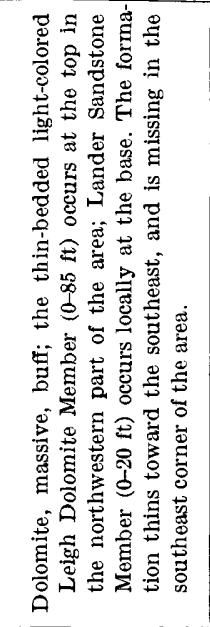 & 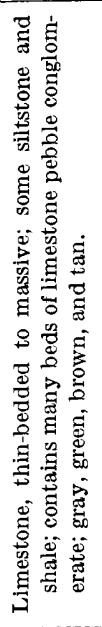 & 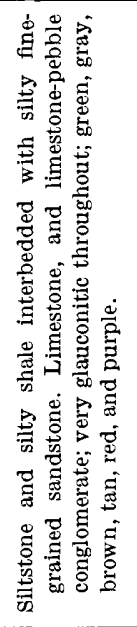 & 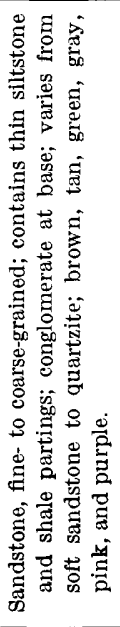 \\
\hline 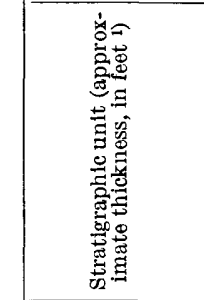 & 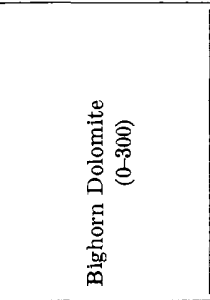 & 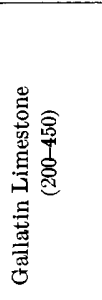 & 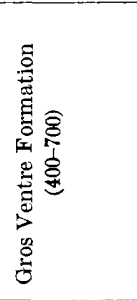 & 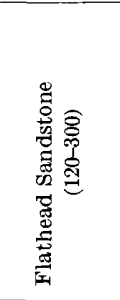 \\
\hline 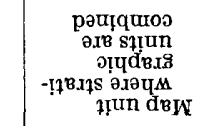 & \multicolumn{4}{|c|}{ 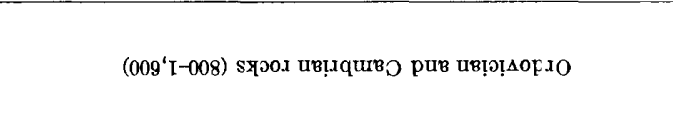 } \\
\hline sə̣ıəs & хәdd $\Lambda$ рив әррр!К & $\operatorname{sədd} \Lambda$ & \multicolumn{2}{|c|}{ әІрp!̣N } \\
\hline แәๆ $\kappa_{\mathbf{S}}$ & บвเฺฺморхо & \multicolumn{3}{|c|}{ ив!̣quвр } \\
\hline BD'A & & & & \\
\hline
\end{tabular}


WIND RIVER INDIAN RESERVATION, WYOMING

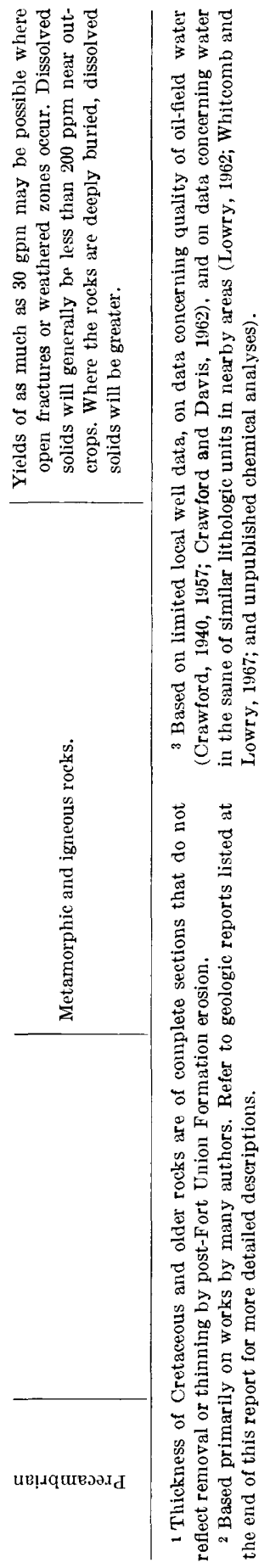


pending on local conditions, but the general movement is down the valley. Alluvium that lies at levels above the streams derives water from precipitation or, in many areas, from irrigation, and discharges most of the water to springs at terrace scarps. Disch arge from the alluvium to existing wells is minor because only a few wells are pumped at high rates.

Evaporation and transpiration return a large portion of the precipitated water to the atmosphere. Evaporation continues from openwater surfaces and from the water table in areas where it is near the land surface. Large amounts of water are transpired by plants during the growing season.

\section{WATER LEVELS}

Water levels in wells reflect the pressure of water in confined aquifers and show the top of the zone of saturation in unconfined aquifers. Changes in the balance between recharge and discharge cause water-level fluctuations. Discharge of water from an aquifer by pumping alters the natural balance and lowers the water level until a new balance is established. Hydrographs of several types of waterlevel fluctuations are shown in figure 4.

Confined aquifers in the area are large, and effects of changes in the balance between recharge and discharge on water levels are dampened. Water levels may vary only a few tenths of a foot during a year, but may change several feet over a period of many years in reaction to long-term changes in balance between recharge and dissharge (fig. 5). However, water levels may decline several tens of feet in a short period in response to local pumping.

Unconfined aquifers in the area are small, and changes in the balance of recharge and discharge have an immediate and pronounced effect on water levels. Short-term variations in precipitation and daily and seasonal variations in evaporation and transpiration ray cause water levels to rise or fall in a short period. Artificial influences, such as irrigation, overcome natural influences and control water levels in many areas (fig. 4 ).

Data concerning water levels in rocks older than the Wind River Formation are sparse. Except in outcrop areas, water in these rocks is generally confined. Well depths are as much as several thousand feet, but water generally will rise to near the surface and, in some areas, will flow. Specific data are given in table 3 and on plate 1.

The Wind River Formation consists of numerous separate aquifers. At a single location, aquifers at different depths will have very different water levels. Differences in depth to water of as much as 140 feet were measured in adjacent wells, A3-3-21ada1 and -21ada2 (fig. 4 ), and also in well A1-2-21bbb (table 3), which was cased and completed at two different depths. 
Most wells in the Wind River Formation tap confined aquifers Well depths are as much as 900 feet, and depths of more than 400 fext are common. Water rises far above the producing zones in most wells and, in some areas flows at the surface. Depths to water generally range from the surface to about 200 feet; but there are many exceptions, and depths to water of more than 500 feet have been measured.

In the part of the Wind River Formation tapped by the Riverton well field, water levels have declined in response to pumping. Figure 6 compares 1951 and 1966 water levels in well A1-4-33ddb, which is influenced by pumping of the well field. Pumpage records for 1951 are not available, but annual pumpage in 1966 is estimated to have been about one-third larger than in 1951.

A few shallow wells in the Wind River Formation tap unconfined aquifers. The water-table wells are generally less than 70 feet deep, and depths to water are generally less than 30 feet.

Water in alluvium and other unconsolidated rock of Quaternary age is unconfined. Wells tapping these rocks are generally less than 50 feet deep, and depths to water are generally less than 20 feet.

\section{AQUIFER CHARACTERISTICS}

Data on aquifer characteristics are available for the Wind River Formation and for the alluvium. The data consists of specific capacities reported by drillers and a few pumping tests. The following discussion relates the data to the thickness of rock that contributes water to a well. Thicknesses of contributing rock were taken from drillers' logs. The data are used to define the range of permeability and specif c capacity per foot of contribution. Specific capacity per foot of contribution is the discharge in gallons per minute, per foot of drawdown, per vertical foot of rock that contributes water to a well. It is related to specific capacity in the same way that permeability is related to transmissibility.

Definitions of several terms related to aquifer characteristics are given in the section on terminology. Symbols used in the discussion include :

$m=$ Saturated thickness or thickness of section that contributes water to a well, in feet.

$P=$ Permeability, in $\mathrm{gpd} / \mathrm{ft}^{2}$.

$Q=$ Discharge, in gpm.

$s=$ Drawdown, in feet.

$\Delta s=$ Change in drawdown per log cycle, in feet.

$T=$ Transmissibility, in gpd/ft.

$t=$ Time since pumping began, in minutes.

$t^{\prime}=$ Time since pumping stopped, in minutes. 

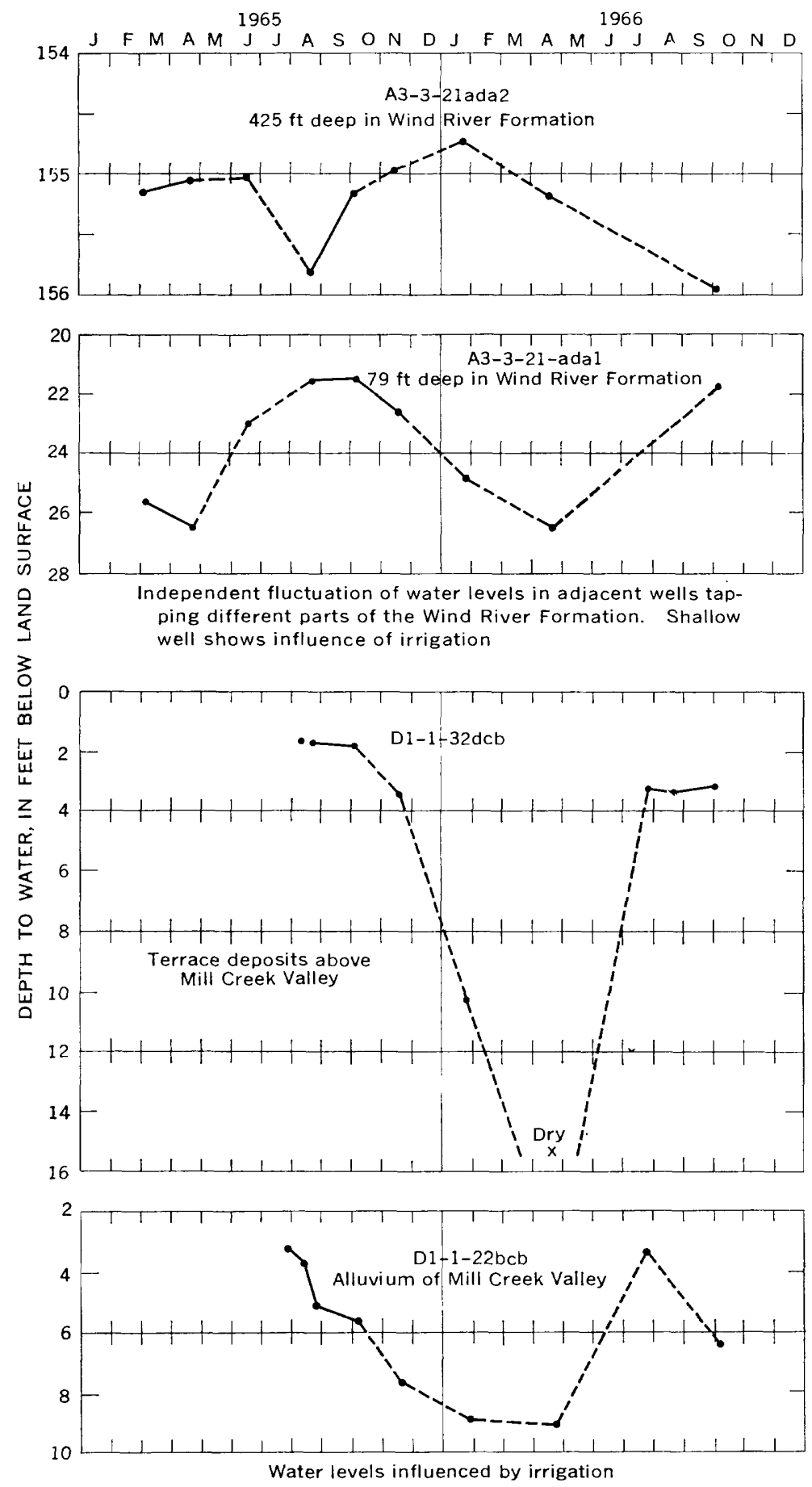

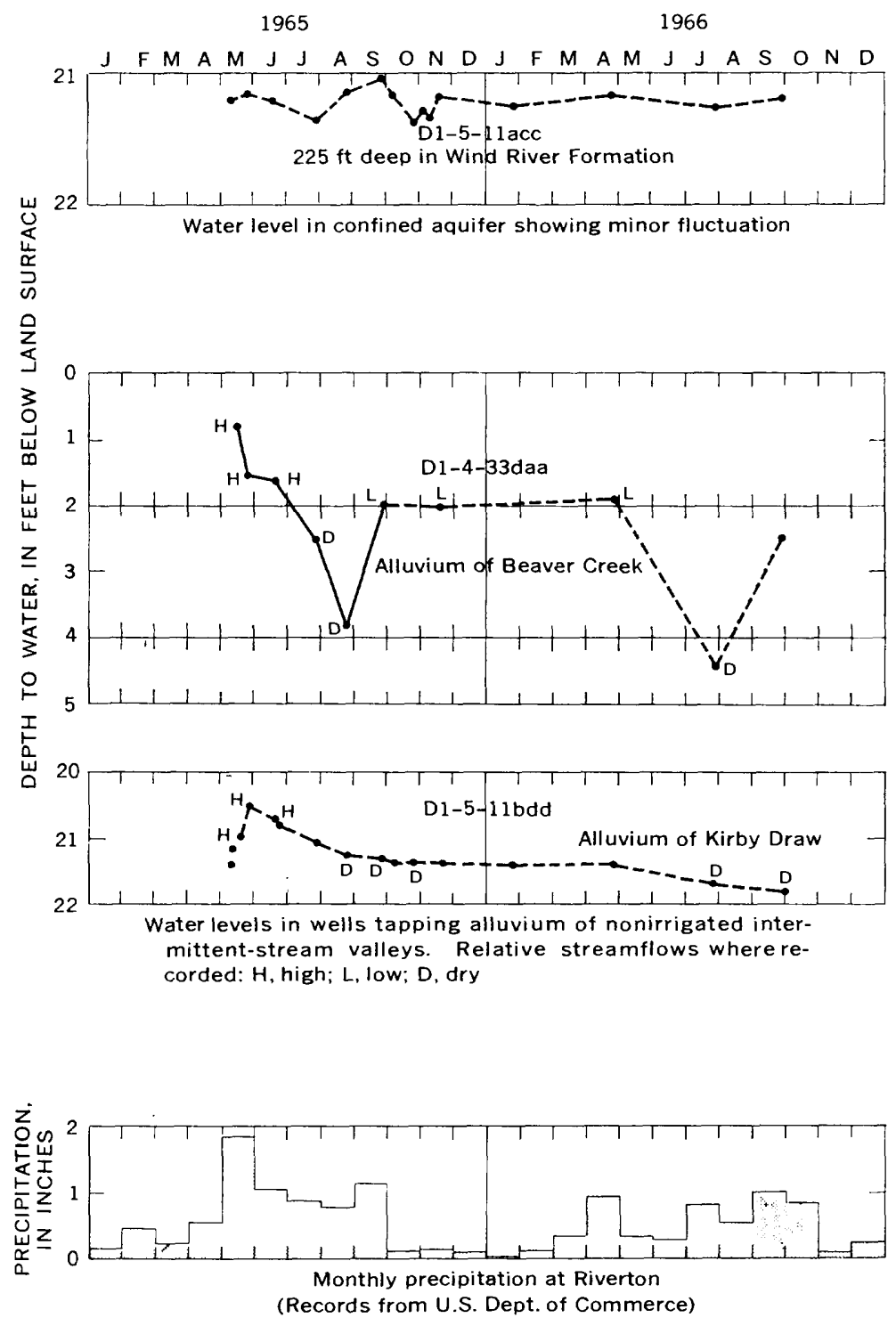

FIgure 4.-Several types of water-level fluctuations in wells. See figure 5 for longer record of well A3-3-21ada2.

\section{WIND RIVER FORMATION}

Data from four pumping tests and specific capacity per fort of contribution for 139 wells tapping the Wind River Formation were available for analysis. The data are from wells in the eastern helf of the area, but the formation probably has similar characteristics throughout the area. 


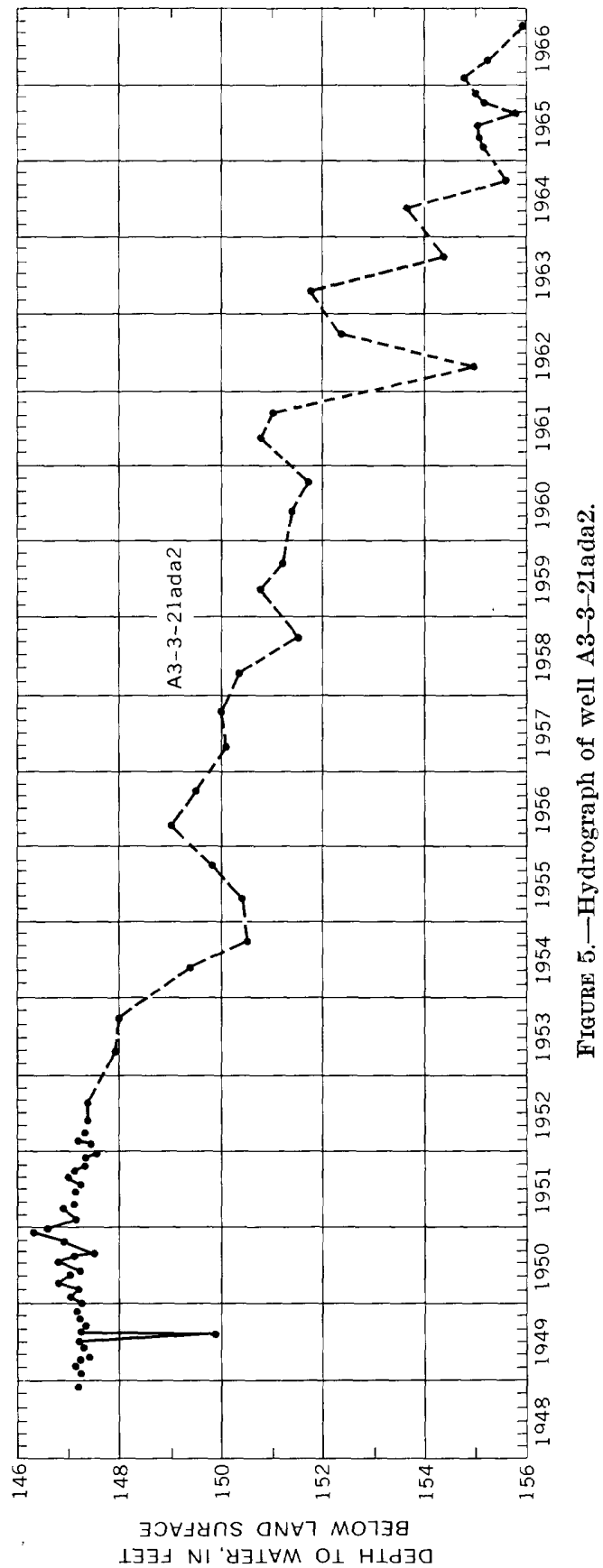




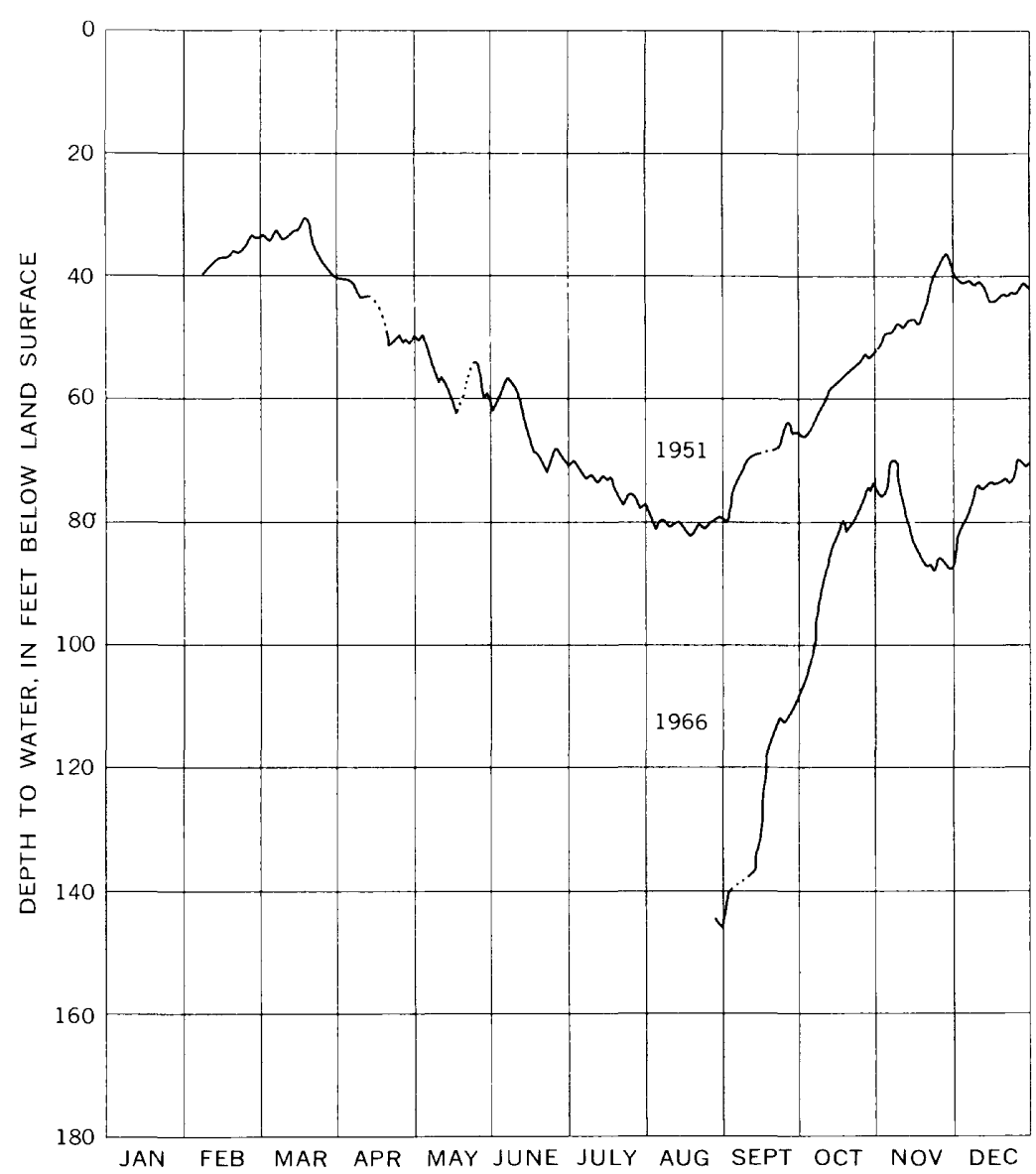

Figure 6.-Hydrograph of well A1-4-33ddb comparing the influence of the Riverton well field in 1951 and 1966. Data from recorder charts.

\section{PUMPING TESTS}

Results of pumping tests (table 2) are expressed as permeability rather than transmissibility, because the Wind River Formation contains numerous separate aquifers and transmissibility of tho formation has little meaning. Some water-bearing beds of the formation are hydraulically connected, but others, perhaps most, are only remotely connected; some are completely separated.

Data from pumping tests were analyzed by methods described by Ferris and others (1962) and also in E. E. Johnson, Inc. (1966). Recovery data were used for analyzing the tests; drawdown data were not considered usable, either because of variation in discharge, or because prepumping trends conld not be defined. Adjusted residnal 
drawdown was plotted against $t / t^{\prime}$ where the prepumping trend was defined. Where only the drawdown trend was defined, adjusted recovery was plotted against $t^{\prime}$. Both plots theoretically give the same result. Figure 7 is a sketch showing the relation of drawdown, residual drawdown, and recovery. Table 2 gives principal data concerning the tests.

Well $A 3-6-15 b c b$.-At the time this test was started, water levels were recovering from effects of previous pumping. The trend of the pretest rise in water level was not defined; thus drawdown data could not be adjusted. The drawdown trend was defined, and recovery data were adjusted accordingly. Figure 8 shows the drawdowr, the adjustment for the drawdown trend, and the adjusted recovery data.

A step-drawdown test of well A3-6-15bcb was made in November 1951. Discharges ranged from about 7 to $50 \mathrm{gpm}$. The specific capacity was $1.3 \mathrm{gpm} / \mathrm{ft}$, which is comparable to that from the 1966 test (table 2).

Well D1-4-4cdd.-The test of well D1-4-4cdd was conducted by a consultant for the owner, Susquehanna-Western, Inc., and data were obtained from the owner. Drawdown was large compared to any probable influence from the Riverton well field, which is about 1 mile north of the well, and interpretation of the test was probably not affected. This well had been pumped irregularly for several months and was shut down for only 15 hours before the test began. The trend of recovery from previous pumping was not known; thus, drawdown data could not be adjusted. The drawdown trend was known, and recovery data were adjusted accordingly. Figure 9 shows the water levels during drawdown, the adjustment for the drawdown trend, and the adjusted recovery data.

Specific capacity from various pumping data were not consistent. Table 2 gives an approximate specific capacity of $2.3 \mathrm{gF} / \mathrm{ft}$, which was interpreted from the data.

Well D1-5-11acc.-Depth-to-water measurements before this test showed a change of only 0.03 foot in 16 hours; thus, no adjustment was required for the prepumping trend, and residual drawdown was analyzed (fig. 10). Drawdown was very sensitive to minor variations in the pumping rate and could not be analyzed.

Riverton well field.-A pumping test of the Riverton vell field was conducted for a previous study in March 1951. The test is described in detail by Morris and others (1959). The test indicates a coefficient of transmissibility of about 6,000 to $10,000 \mathrm{gpd} / \mathrm{ft}$ and a coefficient of storage of about $2 \times 10^{-4}$. The permeability of $180 \mathrm{gpd} / \mathrm{ft}^{2}$ that was computed in 1951, howerer, seems too high to be represertative of the formation. It was based on a thickness of 55 feet, which was the thick- 


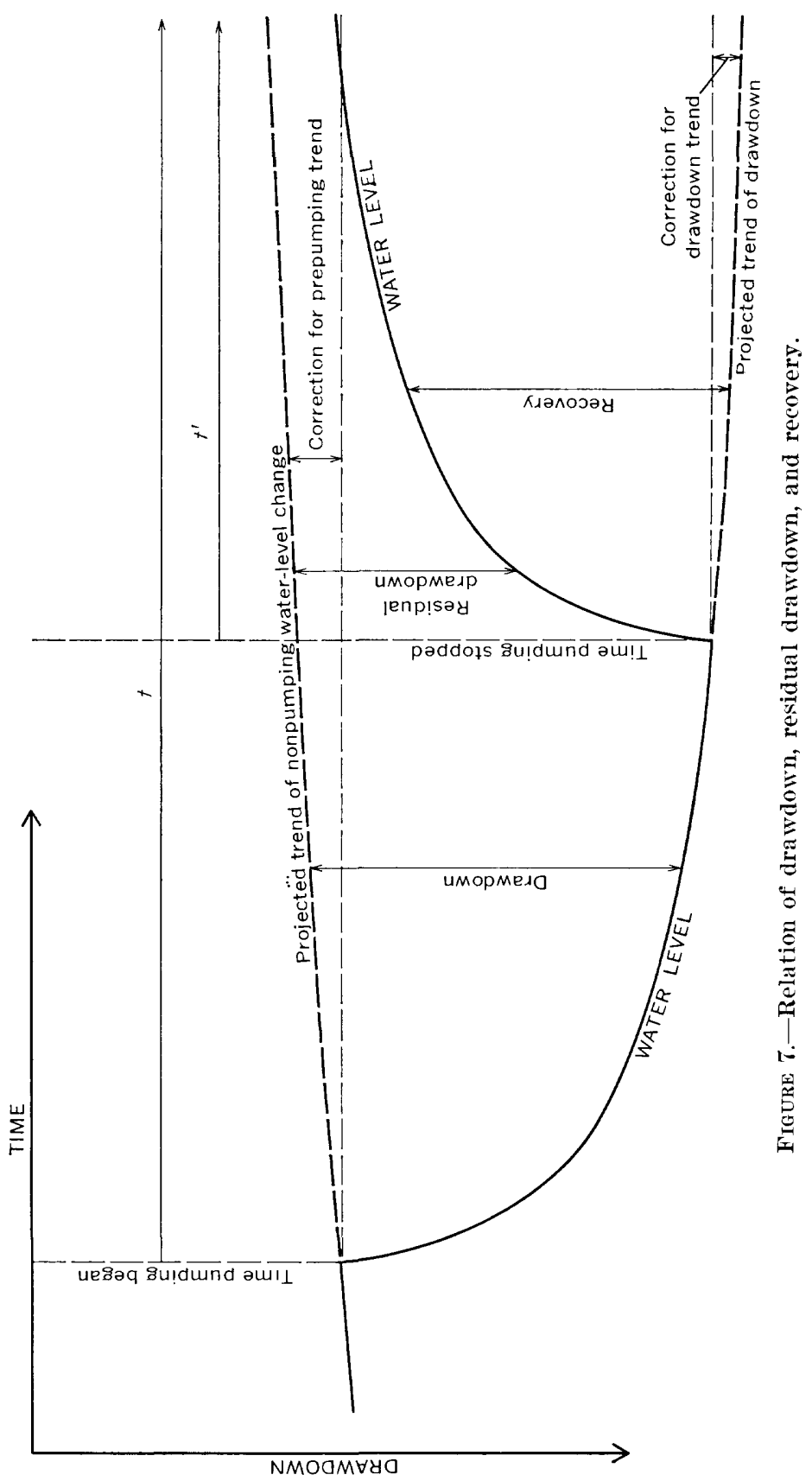




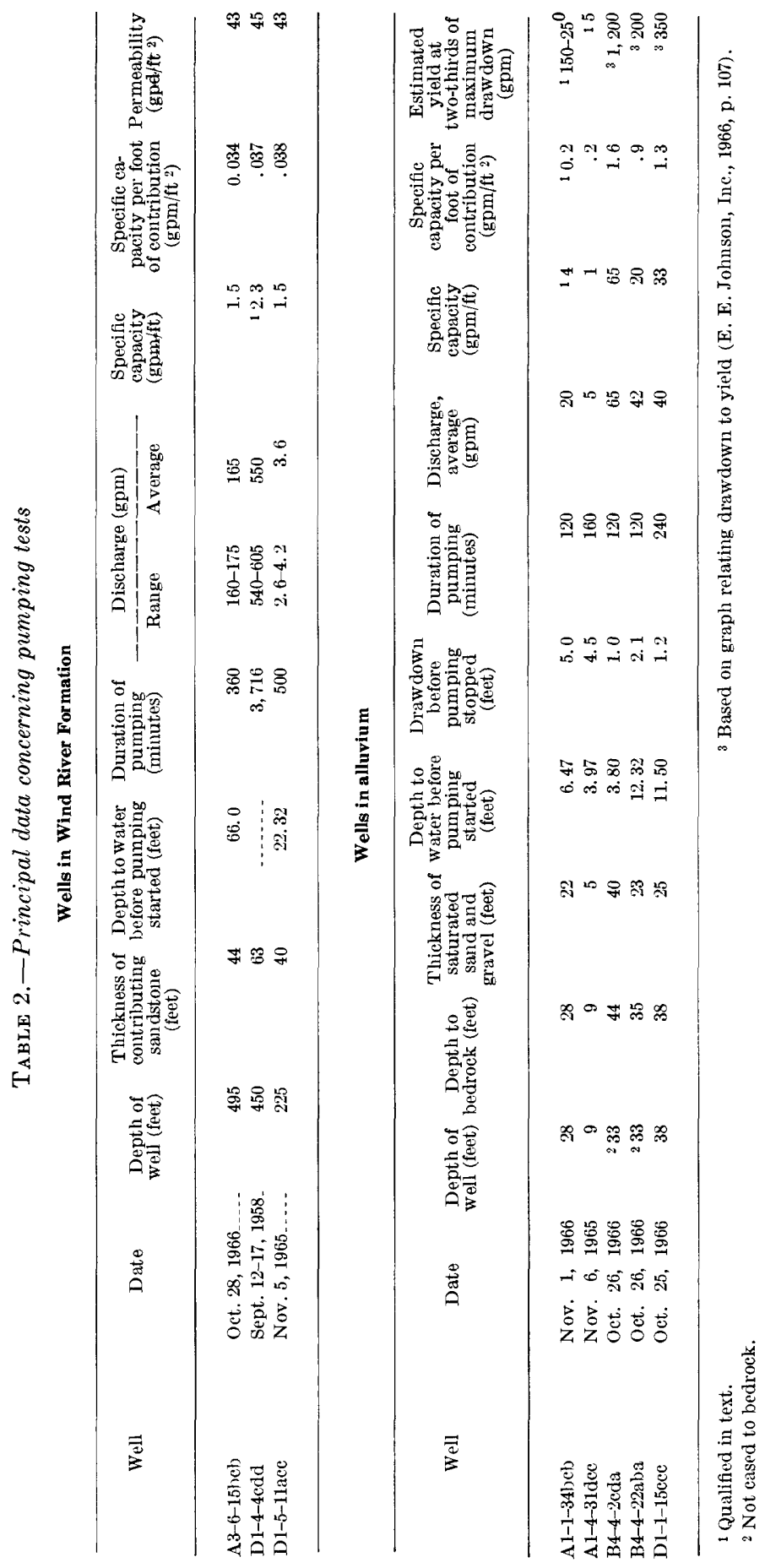




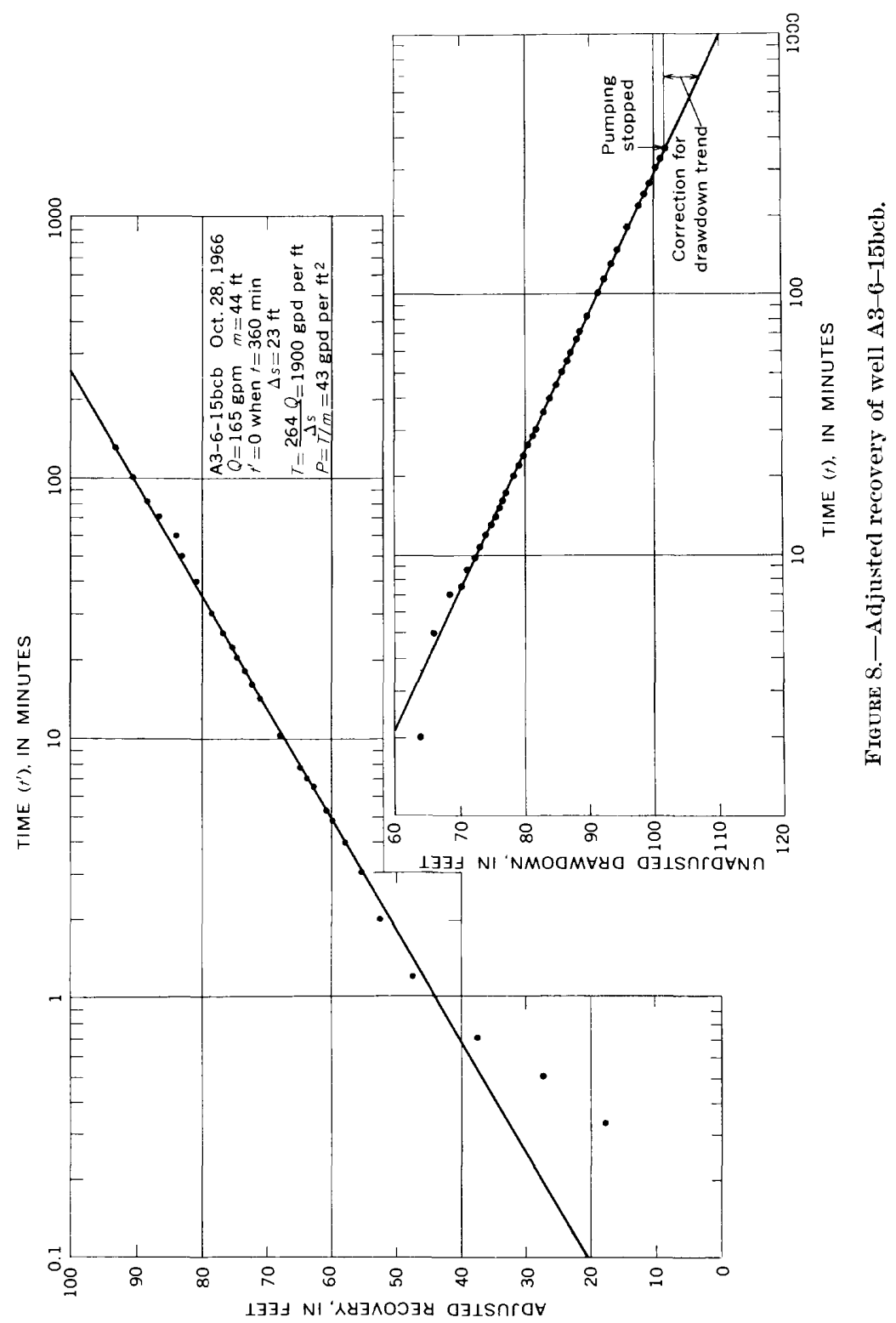



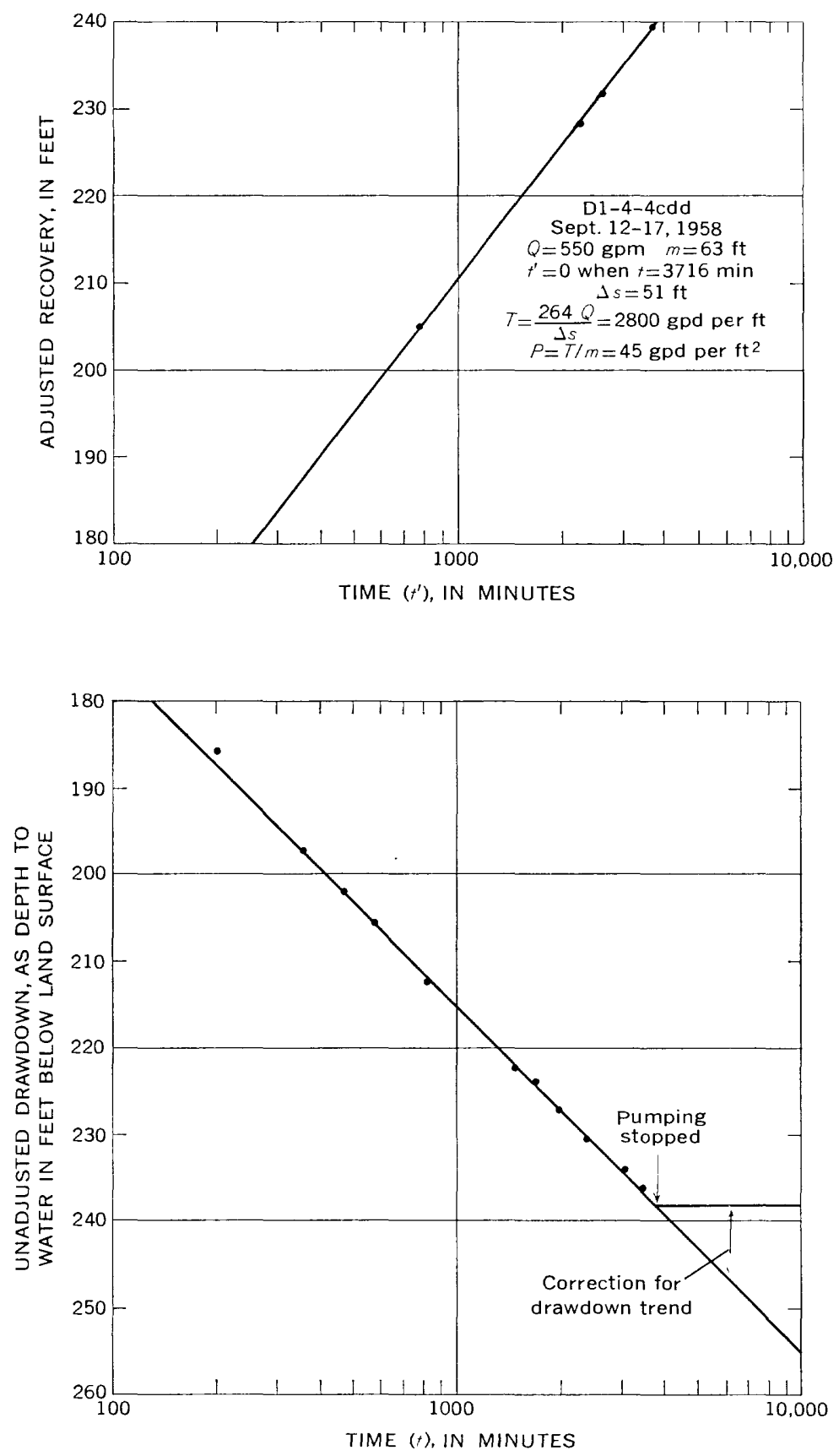

Figure 9.-Adjusted recovery of well D1-4cdd. 


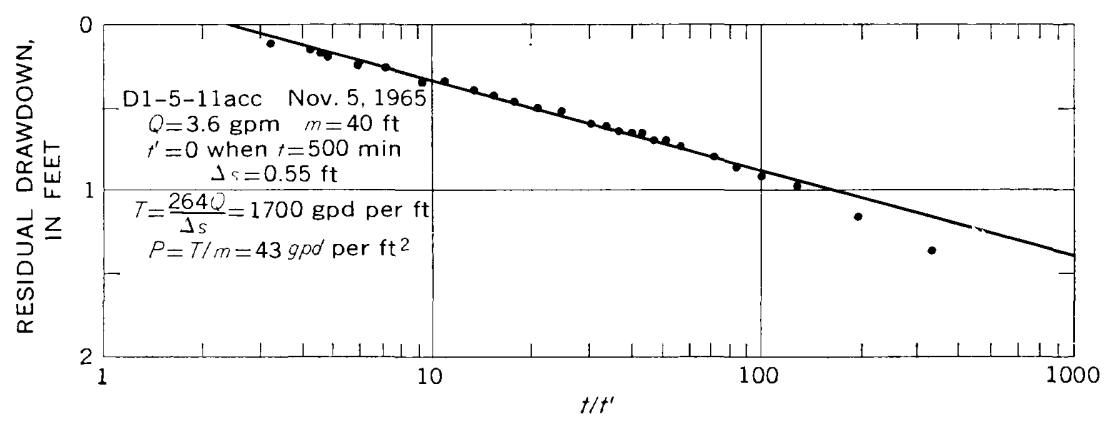

Figure 10.-Residual drawdown of well D1-5-11ace.

ness of water-bearing sandstone open to the pumped well of the test. Drillers' logs show that the "water sands" open to the Riverton wells have thicknesses that range from 45 to 148 feet and a verage about 100 feet per well. Therefore, average permeability based on the average thickness and the transmissibility is between about 60 and $100 \mathrm{gpd} / \mathrm{ft}^{2}$.

\section{SPECIFIC-CAPACITY DATA}

Specific capacity per foot of contributing section for 139 wells in the Wind River Formation is shown in figure 11. Specific cape sity and contributing section were obtained primarily from drillers' records or other reported data. Figure 12 shows the distribution of the data.

Estimates of permeability can be made from the specific capacity per foot of contribution of a well. Specific capacity per foot of contribution $\frac{Q / s}{m}$ and permeability are related in the same way as specific capacity $(Q / 8)$ and transmissibility. This relation has been described by 'Theis, Brown, and Meyer (in Bentall, 1963) and by Johnson and others (1966) and can be expressed as:

$$
\begin{aligned}
& T=K(Q / s), \text { or } \\
& P=K\left(\frac{Q / s}{m}\right),
\end{aligned}
$$

where $K$ combines all factors that affect the relation. Included in $K$ are factors that depend on aquifer characteristics, on well efficiency, and on rate and duration of pumping. Generally, $K$ has a value of 1,5002,100 . but it can be outside this range. Values for $K$ cannot be accurately determined because of the many factors involved, but it can be estimated fairly closely. Even with fairly large errors in $K$, the estimates of permeability will be of the correct order of magnitude.

A value of $K$ that would apply to the data on the Wind River Fornation is probably near 1,500 . Generally, $K$ is larger than this for artesian aquifers; but the available data are for very short pumping 
Data from pumping test

冈 Data for Riverton municipal well

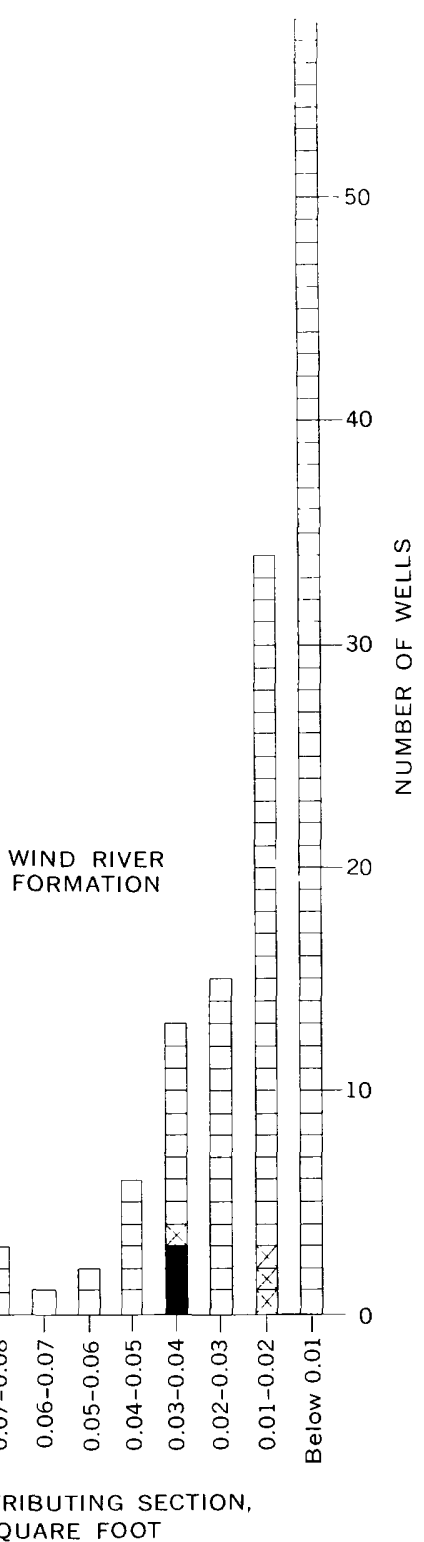

Figure 11.-Histograms of specific capacity per foot of contribution for wells in alluvium and in the Wind River Formation.

periods, and the shorter the pumping period, the smaller the value of ${ }^{2}$. Most of the data are from drillers' tests of probably $2 \mathrm{l}$ ours or less. The relation between specific capacity per foot of contribution and permeability for the tested wells (table 2) indicates a very low $K$ of 


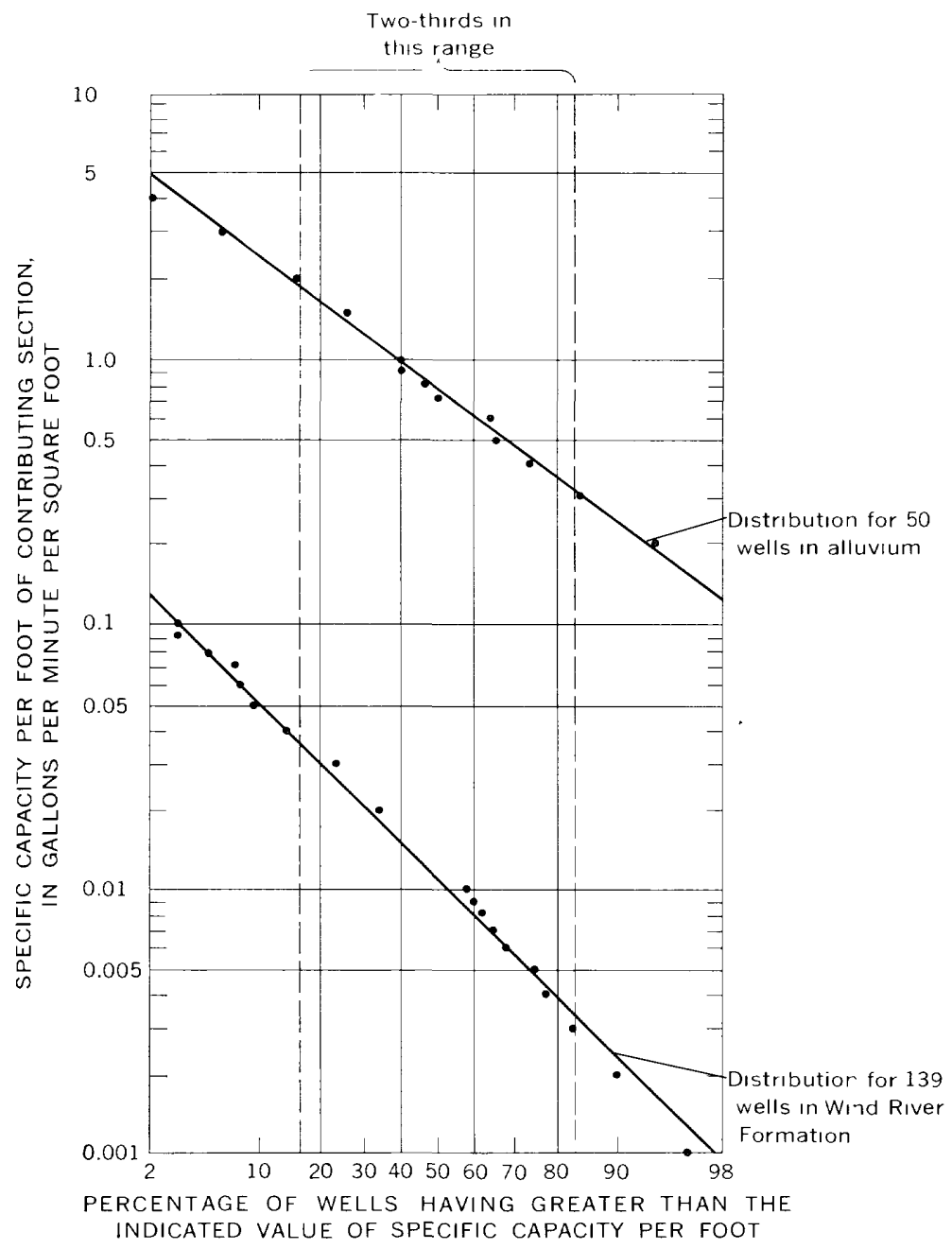

FIGURE 12.-Distribution of specific capacity per foot of contribution for wells in alluvium and in the Wind River Formation.

1,200 . A general value of $K$ of 1,500 is probably adequate for estimating permeabilities from the available data.

The probable range of specific capacity per foot of contribution for water-bearing sandstone of the Wind River Formation is shown in figure 12. This interpretation assumes that the data adequately represent the formation, and that the line drawn throngh the data plot correctly describes the distribution of the data. The probable range of permeability can be estimated by assuming that the $K$ value of 1,500 approximately defines the relation between permeability and the spe- 
cific capacity per foot of contribution. Figure 12 shows that, neglecting the high and low extremes, the probable range of specific capacity per foot of contributions is about $0.001-0.15 \mathrm{gpm} / \mathrm{ft}^{2}$, and the mean is 0.01 $\mathrm{gpm} / \mathrm{ft}^{2}$. The indicated permeability is about 1 to $220 \mathrm{gpd} / \mathrm{ft}^{2}$, and the mean is $15 \mathrm{gpd} / \mathrm{ft}^{2}$. Two-thirds of the wells in the formation will have a specific capacity per foot of contribution betwe?n 0.003 and $0.04 \mathrm{gpm} / \mathrm{ft}^{2}$ and an indicated permeability between 4 and $60 \mathrm{gpd} / \mathrm{ft}^{2}$.

\section{ALLUVIUM}

Data from five pumping tests and specific capacity per foot of contribution for 50 wells tapping the alluvium were available for analysis. All the data are from wells in alluvium underlying flood plains or terraces in the valley of the Wind River or in those tributary-stream valleys that drain the Wind River Mountains. The deposits are generally coarse grained and similar in character. They are quite different from the finer grained deposits of valleys in the southeast, such as the valleys of Beaver Creek and Kirby Draw, and in the center of the basin, such as the valleys of Fivemile and Muddy Creeks. No pumping-test nor specific-capacity data are available for wells in the finer grained deposits; consequently, the following discussion concerns only the coarser deposits.

\section{PUMPING TESTS}

Specific-capacity data were obtained from the pumping tests of the wells in alluvium, and estimates were made of potential yields of the allurium at the test sites. Principal data concerning the tests are given in table 2.

Four of the wells were pumped at minor rates compared to their potential yields because large-capacity pumps were not available for the tests. To estimate potential yields, the relation of the drawdown to the yield was used. Under water-table conditions that exist in the alluvium, specific capacity cannot be used directly to estimate yields at increased drawdowns because the specific capacity decreases significantly with dewatering of the aquifer. As drawdown increases, specific capacity decreases. A graph showing the general relation between drawdown and yield under water-table conditions is given in E. E. Johnson, Inc. (1966, p. 107). When drawdown at a particular yield is known, the yield at a different drawdown for a similar pumping period can be estimated from the graph. According to the graph, the yield at two-thirds of the maximum drawdown is about 90 percent of the maximum yield; table 2 gives the estimated yield at two-thirds of the maximum drawdown.

Well $A 1-1-34 b c b$. - The specific capacity determined by the test of well A1-1-34bcb near Ethete was $4 \mathrm{gpm} / \mathrm{ft}$. This well was poorly de- 
veloped and was partly plugged with sand. Results of the test were affected by well conditions, are not indicative of the aquifer conditions, and cannot be used to estimate the yield of a properly developed well: Test drilling indicated that the water-bearing deposits were similar to those tapped by the other tested wells. Based on comparison with the other well tests, an estimated yield of about $150-250 \mathrm{gpm}$ at. two-thirds of the maximum drawdown may be possible for a properly developed well in the Ethete area.

Well A1-4-31dcc.-Well A1-4-31dce was pumped at about its maximum discharge, $5 \mathrm{gpm}$. This well is probably less productive than is possible for the area, but large yields are not possible from wells because of the limited saturated thickness. Howerer, very large sumps or other methods of greatly increasing the effective diameter could produce larger yields.

Wells B-4-2cda and B4-4-22aba.-Wells B4-4-2cda and Bt-4 22 aba did not penetrate the full thickness of alluvium, but drewdowns were very small and effects of partial penetration were probably negligible.

Well. D1-1-15cce.-At well D1-1-15cec, the sand and gravel is overlain by 13 feet of sandy silt, which is partly saturated. The silt is of relatively low permeability, and, for the short test, it was not considered as part of the contributing thickness.

\section{SPECIFIC-CAPACITY DATA}

Specific capacity per foot of contributing section for 50 wells in alluvium are shown in figure 11. About 80 percent of the data is taken from drillers' reports of wells in the Little Wind River valley near Fort Washakie. The deposits in the Fort Washakie area are generally similar to those in other valleys draining the Wind River Mountains, and the range of specific capacity per foot of contribution is probably also similar. Figure 12 shows the distribution of the data.

The approximate relation between specific capacity per foot of contribution and permeability has already been discussed relative to the Wind River Formation. It is expressed as :

$$
P=K\left(\frac{Q / s}{m}\right) \text {. }
$$

$A$ value of $K$ that would apply to the data of the allurium is probably near 1,500 , but there are no permeability data available for comparison.

The probable range of specific capacity per foot of contribution for the alluvium is shown in figure 12. This interpretation assumes that the data adequately represent the alluvium and that the line drawn through the data plot correctly describes the distribution of the data. 
The probable range of permeability can be estimated by assuming that the $K$ value of 1,500 approximately defines the relation between permeability and the specific capacity per foot of contribution. Figure 12 shows that, neglecting the high and low extremes, the probable range of specific capacity per foot of contribution is about $0.1-5 \mathrm{gpm} / \mathrm{ft}^{2}$, and the mean is $0.8 \mathrm{gpm} / \mathrm{ft}^{2}$. The indicated permeability is about 150 $7,500 \mathrm{gpd} / \mathrm{ft}^{2}$, and the mean is $1,200 \mathrm{gpd} / \mathrm{ft}^{2}$. Two-thirds of the wells in the alluvium will have a specific capacity per foot of contribution between 0.3 and $2 \mathrm{gpm} / \mathrm{ft}^{2}$ and an indicated permeability of $450-3,000$ $\mathrm{gpd} / \mathrm{ft}^{2}$.

\section{GEOLOGIC UNITS IN RELATION TO GFOUND WATER}

Most water wells in the area derive water from the Wind River Formation and from alluvium. Consequently, most of the data collected in conjunction with this study concerns these depcsits. Discussions of other units are based on limited local well data, on data concerning quality of oil-field waters (Crawford, 1940, 1957; Crawford and Daris, 1962), and on data concerning water in nearby areas (Lowry, 1962: Whitcomb and Lowry, 1967; and umpublished chemical analyses). Lithologic descriptions of the rocks are based largely on published works of other authors. The selected references at the end of the report provide references to more detailed descriptions of the geologic formations and their stratigraphic relations. (See table 1 for descriptions of individual formations.)

\section{PRECAMBRIAN ROCKS}

Metamorphic and igneous rocks of Precambrian age are exposed in the Wind River Mountains and in scattered outcrops in the Washakie and Owl Creek Mountains. Yields of as much as $30 \mathrm{gpm}$ may be possible where open fractures or weathered zones occur. Dissolved solids in the water will generally be less than $200 \mathrm{ppm}$ near outcrops. Two springs (B7-1-1cad and B7-1-2aab), which probably derive water from Precambrian rocks, have specific conductances of 200 and 140 micromhos (dissolved solids of less than $150 \mathrm{ppm}$ ). Dis:olved solids will be greater where the rocks are deeply buried.

\section{PALEOZOIC ROCKS}

Paleozoic rocks consist predominantly of limestone, dolomite, and sandstone, but include lesser amounts of chert, shale, siltstone, and claystone. The rocks are mostly gray, brown, and buff, but some are green, red, purple, and white. Outcrops are predominantly gray and 
buff. Paleozoic rocks range in thickness from about 1,900 to $: 3,600$ feet. The thickness is greatest in the southwest; the rocks thin east ward and, to a lesser degree, northward. Most. Paleozoic rocks are massive; steep clifts and narrow valleys occur in outcrop areas.

Paleozoic rocks crop out along the flanks of the mountains and are deeply buried in most of the basin. The rocks dip steeply along the northeast slope of the Wind River Mountains toward a deep trough paralleling the range. Northeast of this trough, the rocks are relatively near the surface-but do not crop out-in a central anticlinal structure that runs generally parallel to the Wind River Mountains (pl. 2). The rocks are very deeply buried in the north-central part of the Wind River Basin near Boysen Reservoir, and occur in folded and complexly faulted blocks along the south slope of the Washakie and Owl Creek Mountains. The rocks also crop out along the north slope of the Owl Creek Mountains where they dip regionally northward toward the Bighorn Basin.

Many of the Paleozoic rock units are potentially high yielding aquifers. Yields of more than $1,000 \mathrm{gpm}$ are possible from the ronks comprising the Bighorn Dolomite, Darby Formation, Madison Limestone, and Tensleep Sandstone. Wells tapping similar rocks near Tensleep, Wyoming, in the Bighorn Basin, flow as much as 2,500 gpm (Lowry, 1962). Except in carernous or intensely fractured zones, permeabilities are not high, but large flows are possible because of thick sections of water-bearing rock and because of high pressures. Where pressures are low, as near outcrops, yields may be relatively low except where the rocks are cavernous or intensely fractured.

Water from Paleozoic rocks commonly contains various gases and oil. Dissolved solids in water from most Paleozoic rocks range from about 300 to $3,000 \mathrm{ppm}$, but Permian rocks yield water having about 1,000 to more than $10,000 \mathrm{ppm}$ dissolved solids.

Economic drilling depths limit the potential derelopment of ground water from Paleozoic rocks to a narrow belt along the northeast flank of the IVind River Mountains, to a somewhat wider belt along the north flank of the Owl Creek Mountains, and to parts of the central anticlinal structure. Depths to the Paleozoic rocks in the basin may be estimated from the generalized structure contours shown on plate 2 . The top of the Paleozoic rocks is about 2,000-3,000 feet below the horizon shown by the contours.

\section{MESOZOIC ROCKS}

\section{LOWER MESOZOIC ROCKS}

The lower Mesozoic rocks (Triassic and Jurassic rocks excluding the Morrison Formation) consist of siltstone, shale, and sandstone and 
lesser amounts of limestone, dolomite, and gypsum. Tlo rocks are mostly red, salmon, and green, but some are purple, ochre, gray, tan, and yellow. Outcrops are predominantly red and light green. The lower Mesozoic rocks range in thickness from about 1,400 to 2,200 feet. They are thickest in the southwest and thin eastward and northward. The lower Mesozoic rocks are generally less resistant to erosion than Paleozoic rocks; hills and ridges and moderately broad valleys occur in outcrop areas.

The lower Mesozoic rocks crop out along the flanks of the mountains and on some of the structures within the basin. The rocks dip from the flanks of the Wind River Mountains toward the deep trough paralleling the range. Northeast of this trough, the rocks crop out, or are at relatively shallow depths on the central anticlinal structure and on the structures in the Maverick Springs-Circle Ridge aren. The rocks are very deeply buried in the north-central part of the Wind River Basin near Boysen Reserroir and occur in folded and complexly faulted blocks along the south slope of the Washakie and Owl Creek Mountains. The rocks also crop out along the north slope of the Owl Creek Mountains where they dip regionally northward toward the Bighorn Basin.

Moderate to high yields of water may be available from some of the lower Mesozoic rocks. Yields of as much as several huntred gallons per minute may be possible from the Nugget Sandstone. Yields of 20 $\mathrm{gpm}$ or more are possible from the Sundance Formation and Crow Mountain Sandstone. Yields of as much as $10 \mathrm{gpm}$ mar be possible from some of the other lower Mesozoic rocks, but most of these rocks will yield little, if any, water.

Water from the lower Mesozoic rocks generally contains high concentrations of dissolved solids, but, near outcrops in some locations, the dissolved solids are less than $1,000 \mathrm{ppm}$. Some oil-field waters have dissolved solids of more than $20,000 \mathrm{ppm}$.

Economic drilling depths limit the potential development of ground water from lower Mesozoic rocks to narrow belts along the flanks of the mountains and to parts of the major anticlinal structures within the basin. Depths to the lower Mesozoic rocks in the basin may be estimated from the generalized structure contours shown on plate 2. The top of this sequence of rocks, the top of the Sundanc? Formation, is about $350-650$ feet below the horizon shown by the contours.

\section{UPPER MESOZOIC ROCKS}

The upper Mesozoic rocks (Cretaceous rocks and the Morrison Formation) consist of shale and sandstone and lesser amounts of siltstone, claystone, conglomerate, coal, and bentonite. The rocks are mostly 
gray, black, and brown, but some are buff, red, purple, and white. Outcrops are predominantly gray and brown. The upper Mesozoic rocks range in thickness from about 4,000 to 12,000 feet. The thickness is greatest in the north-central and east-central parts of the area. The rocks are mostly nonresistant shale and soft sandstone, but some are resistant beds of harder sandstone. Broad shallow valleys separated by numerous hogbacks and cuestas occur in outcrop areas.

The youngest of the upper Mesozoic rocks were removed by erosion in the southwestern half of the area before rocks of Eocene : ge were deposited. Remaining upper Mesozoic rocks crop out in a thin belt along the flanks of the Wind River Mountains and on the central anticlinal structure. The complete section of upper Mesozoic rocks is exposed on structures in the north-central part of the area; eastward, near Boysen Reservoir, they are deeply buried. Part of the section is exposed at Alkali Butte in the southeast corner of the area. The rocks also crop out along the north slope of the Owl Creek Mountains where they dip regionally northward toward the Bighorn Basin.

Moderate to high yields of water may be available from some of the upper Mesozoic rocks but most yields will be low. Yields of as much as several hundred gallons per minute may be available from the Cloverly and Morrison Formations and from the Mesaverde and Lance(?) Formations. Yields of as much as 50 gpm may be available from sandstone of the Frontier and Meeteetse Formations. Yields of as much as $20 \mathrm{gpm}$ may be possible from sandstone beds in the Mowry and Thermopolis Shales and Cody Shale.

Dissolved solids generally range from about 1,000 to $5,000 \mathrm{ppm}$, but may be much higher in some oil-field waters. In some areas, water with less than $1,000 \mathrm{ppm}$ dissolved solids may be arailable from the Clorerly and Morrison Formations.

Economic drilling depths limit the potential development of ground water from upper Mesozoic rocks to the major anticlinal structures within the basin. The generalized structure contours (pl. 2) show the top of the Cloverly Formation, which is about $350-650$ feet above the base of the upper Mesozoic rocks.

\section{CENOZOIC ROCKS}

\section{TERTIARY ROCKS}

FORT UNION FORMATION

The Fort Union Formation consists of interbedded sandstone, conglomerate, shale, and siltstone. The rocks are gray, olive, buff, brown, and tan: some zones are red and purple. The thickness ranges from 0 to about 7,000 feet. The rocks are thickest in the north-central part of 
the Wind Rirer Basin near Boysen Reservoir; they thin toward the southwest.

The Fort Union Formation is not present southwest of the central anticlinal structure but crops out along the northeast side of this structure, on Alkali Butte, and in the Shotgun Butte area. It underlies rocks of Eocene age in the center of the basin.

The few water wells in the area that tap the Fort Union Formation have yields of less than $10 \mathrm{gpm}$ of water haring dissolved solids of about $1,000 \mathrm{ppm}$. These wells tap only a small part of the formation. The potential yield of a well tapping the complete formation could be as much as sereral hundred gallons per minute. Existing wells, which are near outcrops, proride water that is of better quality than water from most of the formation. Generally, dissolved sc lids in water from the Fort Cnion would range from about 1,000 to 5,000 ppm.

\section{INDIAN MEADOWS FORMATION}

The Indian Meadows Formation or equivalent rocks underlie the Wind River Formation in much of the basin, but are not differentiated in the subsurface. The Indian Meadows consists of conglomerate, sandstone, claystone, siltstone, and some limestone. The rocks are brick red and rariegated red, purple, lavender, tan, gray, green, buff, brown, and white; reddish colors are generally predominant. The thickness ranges from 0 to about 3,000 feet. The formation crors out in the northern and northwestern parts of the area but not in the southern part.

The Indian Meadows Formation is a potential aquifer, but no warer wells are known to tap it. Yields of as much as $50 \mathrm{gpm}$ may be possible, but some of the rocks will not yield water. Dissolved solids probably range from about 1,000 to $5.000 \mathrm{ppm}$.

\section{WIND RIVER FORMATION}

The Wind River Formation consists of sandstone, conglomerate, siltstone, claystone, and shale; some parts of the formation contain small amounts of bentonite, tuff, and limestone. The rocks are partly gray, green, and yellow; partly red, maroon, and brown; and partly varicolored. The thickness ranges from 0 to about 5,000 feet.

A diagrammatic section (fig. 13) shows the approximate relations of the major facies of part of the Wind River Formation in the eastern part of the reservation, east and north of the central anticlinal structure. The diagram and the following discussion are based on interpretation of published descriptions of the formation, on oil-well logs, and on data obtained from test drilling (table 5). This interpretation of the relations is oversimplified and should be regarded as preliminary. 


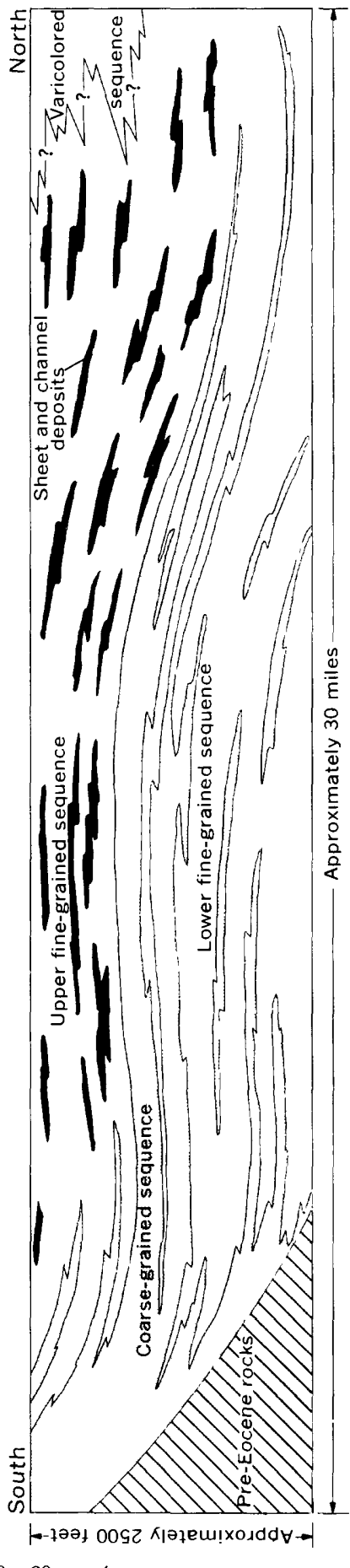

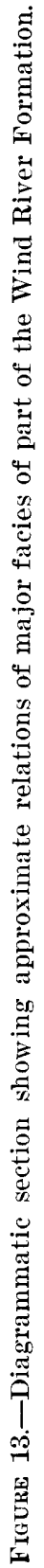


Further refinement of the relations would require investigations beyond the scope of this report. Although preliminary, the relations as presented form a reasonable basis for exploration for water in the formation.

The oldest Eocene rocks shown on the diagram are the lower finegrained sequence of the Wind River Formation, which is probably several thousand feet thick. These rocks are mostly brown, maroon, red, and gray siltstone and shale and some sandstone. Undifferentiated older rocks of the Wind River Formation and rocks of the Indian Meadows Formation underlie the sequence, but are not shown on the diagram (fig. 13). The lower fine-grained sequence is overlain by, and intertongues toward the south with, a coarse-grained sequence.

The main body of the coarse-grained sequence is prol-bly about 1,000 feet thick along the northeast side of the central anticlinal structure, but the sequence thins toward the northeast. The rocks consist of green and gray, largely arkosic sandstone, conglomerate, and siltstone. Many of the coarse-grained sandstone and conglomerate beds are very well sorted, loosely cemented, and very porous. The coarsegrained sequence crops out along the northeast side of the central anticlinal structure and north of Alkali Butte. On the outcrop, most of the rocks have weathered to rusty tan and yellow colors. The coarsegrained sequence intertongues with and underlies an upper fine-grained sequence.

The upper fine-grained sequence is at the surface in most of the eastern part of the reservation. The maximum thickness of the sequence is about 800 feet in most of the area, but it is thicker in the northeast near the structural trough (pl. 2). These rocks are mostly gray and green siltstone, shale, and sandstone, but there are also thin beds of red, maroon, and green siltstone and shale. Toward the north, the red, maroon, and green rocks are thicker and become $\varepsilon$, large part of the sequence. Numerous sheet and channel deposits of brown siltstone and sandstone occur in the sequence.

The youngest rocks of the Wind River Formation in the eastern part of the reservation are a complex varicolored sequence that occurs along the north margin of the basin. These rocks are grouped together for simplicity because they are poorly known, but they contain several facies and probably exceed 1,000 feet in maximum thickness. The rocks consist of claystone, siltstone, shale, sandstone, conglomerate, and limestone. They are generally colorful; red, green, yellow, maroon, and violet are common. Most of the rocks are composed of Paleozoic and Mesozoic rock fragments. Relations of the varicolored sequence in the northeastern part of the reservation with other rocks of the Wind River Formation are assumed to be as shown in figure 13. 
In the western part of the reservation, the rock sequences are similar to those in the eastern part. The basin, however, is narrower in the west, and conglomeratic rocks along the margins of the basin are a larger part of the formation and the basinward finer grained facies, a lesser part. The lower fine-grained sequence is probably represented in the deep part of the structural trough (pl. 2) west and south of the central anticlinal structure. Rocks similar to the coarse-grained sequence are present and crop out in many places along the Wind River valley. Along the margin of the basin to the southwest, the sequence becomes largely conglomeratic. The upper fine-grained sequence is present and intertongues northward with conglomerate and brightly colored finer grained rocks that are similar to the varicolored sequence present in the east. Overlying the upper fine-grained sequence and parts of the varicolored sequence are 200-300 feet of tuffacec'is rocks, which consist mostly of buff sandstone and white and pink tuff.

Most wells in the Wind River Formation tap sandstone of the upper fine-grained sequence. Yields are as much as $50 \mathrm{gpm}$, but most wells have lower yields. The most productive aquifers are in the coarsegrained sequence. Wells tapping these rocks, as in the Riverton well field, yield as much as $500 \mathrm{gpm}$. Few, if any, wells tap the other rocks of the Wind River Formation.

The Wind River Formation contains water having dissolved solids that generally range from about 200 to $5,000 \mathrm{ppm}$. Most of the water in the upper fine-grained sequence contains more than $1,500 \mathrm{ppm}$ of dissolved solids. Water with lower concentrations of dissolved solids, however, occurs in some sandstones where recharge water contains low concentrations of dissolved solids and where the water infiltrates through rocks containing small amounts of soluble salts.

Water from many wells tapping the coarse-grained sequence has dissolved solids of 200-1,000 ppm; however, some rocks in this sequence have water containing very high concentrations of dissolved solids. Most wells that yield water containing dissolved solids of less than 1,000 ppm, including the Riverton well field, tap the coarsegrained sequence at altitudes lower than where the sequence is crossed by the Wind and Little Wind Rivers (Kinnear and Johnstown Valleys along the Wind River south of Morton, and about 5 miles west of Arapahoe on the Little Wind River). These are assumed to be principal recharge areas for part of the coarse-grained sequence.

The Wind River Formation has a large potential for continued development. Water of quantity and quality suitable for stock use is arailable from the formation in almost any area, although well depths of 500 feet or more will be necessary in a few places. Wells yielding several hundred gallons per minute are possible from some aquifers in 
the coarse-grained sequence. Water of quality suitable for drinking or other uses requiring low concentrations of dissolved solids is available from some aquifers of the formation. The dissolved solids and specificconductance data shown on plate 1 indicate the quality of water and the depths at which it is found locally.

\section{OTHER TERTIARY ROCKS}

Other Tertiary rocks in the area are the Aycross, Tepee Trail, and Wiggins Formations and an unnamed tuff. These rocks consist of conglomerate, breccia, tuff, sandstone, and claystone. Volcanic rock fragments and tuff are predominant. Colors are pink, white, green, olive, brown, yellow green, and gray. The combined thickness ranges from 0 to more than 3,000 feet. The rocks and their equivalents have been removed by erosion from most of the area. The Aycross, Tepee Trail, and Wiggins occur only in the northwest corner of tha area. The unnamed tuff is present only along the north margin of the basin near Boysen Reservoir.

The rocks are largely drained because of their high topographic position. Where they contain water, yields of as much as 50 gpm may be possible; but no water wells are known to tap them in the area. Water from most of these rocks would probably contain less than $2,000 \mathrm{ppm}$ of dissolved solids.

\section{QUATERNARY ROCKS}

A few deposits of travertine occur along the northeast slope of the Wind River Mountains in the western part of the area. They are associated with dissected high terraces and may yield water locally to springs. Landslide and steep-slope colluvial deposits occur along the margins of the mountain ranges. These rocks may also yield water locally to springs. Glacial deposits occur in and along the northeast flank of the Wind River Mountains. They are described in detail by Richmond and Murphy (1965) and by Murphy and Richmond (1965). Some of the glacial deposits will yield water. (See table 1.)

\section{TERRACE AND PEDIMENT DEPOSITS}

Remnants of many terraces and pediments occur throughout the basin and along the margins of the mountains. Deposits that consist predominantly of gravel, sand, and cobbles underlie these surfaces to depths of as much as about 80 feet, but generally the thickness is less than 30 feet.

These deposits are largely drained except in irrigated areas. Thin saturated zones probably underlie some of the more extensive nonirrigated terraces and would yield a few gallons per minute. This water would probably contain more than $1,500 \mathrm{ppm}$ dissolved solids. 
Deposits underlying irrigated terraces will contain water, at least through the irrigation season. The saturated thickness will decrease after irrigation ceases, and some of these deposits may bo nearly drained before irrigation resumes. Potential yields range frcm a few gallons to a few hundred gallons per minute and depend to a large extent on the thickness of saturation. The water will generally contain about $300-2,000 \mathrm{ppm}$ dissolved solids, but the concentration may be much higher in areas of poor drainage. The quality will change seasonally because of the irrigation, and the concentration of dissolved solids will be highest in the spring before irrigation begins.

\section{SLOPE WASH AND ALLUVIUM}

Deposits mapped as slope wash and alluvium on the geologic map (pl. 2) include slope wash, slope wash and interbedded or underlying alluvium, and alluvium of smaller stream valleys where slope wash and alluvium have not been mapped separately. The thickness of these rocks range from 0 to about 80 feet. Slope wash is generally fine grained and consists predominantly of silt, clay, and sand. Alluvium is both fine and coarse grained.

In the upper reaches of many of the stream valleys, the alluvium has not been mapped separately from slope wash. Yields of a few gallons per minute are a railable from many of these rocks.

In the Mill Creek valley, alluvium interbeds with and underlies slope wash. The allurium consists predominantly of sand and gravel, and the slope wash is predominantly sand and silt. Sections of these rocks are shown on plate 3 . Yields of a few to several hundred gallons per minute are arailable. Dissolved solids range from about 500 to $5,000 \mathrm{ppm}$.

In Kirby Draw and Bearer Creek valley in the southeast, the allurium is predominantly sand and silt; slope wash and alluvium are very similar and have not been mapped separately. Sections of the allurium of Kirby Draw are shown in figure 1t. A few test holes augered in the Beaver Creek valley penetrated similar deposits. Part of the allurium is well-sorted sand and very fine gravel that would probably vield as much as $20 \mathrm{gpm}$. Chemical analyses (table 6) indicate that water having dissolred solids of about $1.500 \mathrm{ppm}$ is arailable from shallower wells in at least parts of the valleys. Some of the water in th o deeper part of the allurium contains more than $4.000 \mathrm{ppm}$ dissolved solids. as is shown by the analysis of water from well D1-5-11bdd (table 6).

North of the Wind River in the central part of the basin, the rocks consist mostly of fine-grained slope wash and poorly sorted fine- to coarse-grained allurium that underlies slope wash. These rocks contain water in some places, but mostly they are thin, tight. or drained. 


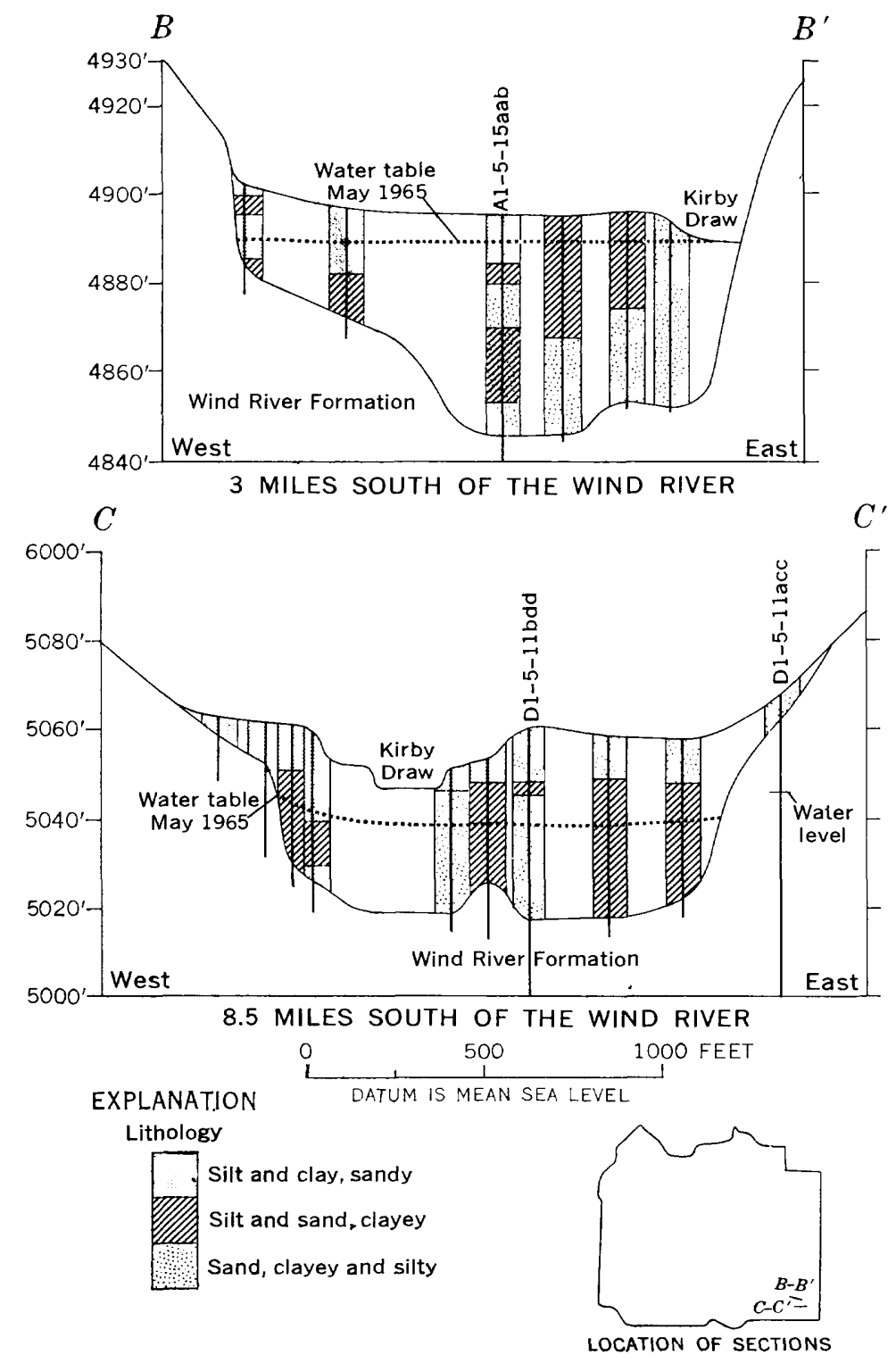

FIgCre 14.- Rections of alluvium in Kirby Iraw. Lines of sections are shown on geologic map. Numbered holes are assed wells for which data are given in tables. 
Where they will yield water, less than $20 \mathrm{gpm}$ would genarally be expected. The water probably contains about $1,000-\tilde{5}, 000 \mathrm{ppm}$ dissolved solids.

\section{ALLUVIUM OF FLOOD PLAINS AND RELATED LOW TERRACEא}

Deposits mapped as alluvium of flood plains and related low terraces (pl. 2) are of two general types, coarse grained and relatively fine grained. The thickness ranges from 0 to about 100 feet, but most of the alluvium is less than 40 feet thick.

Alluvium is generally coarse grained in the Wind River valley and in the valleys of those tributaries that flow northeastward from the Wind River Mountains. Representative sections of alluvium in these valleys are shown on plate 3. Crow Creek valley in the northwest and Owl Creek valley along the northern border of the area also l ave generally coarse-grained alluvium. Gravel, sand, and cobbles are predominant; silt, clay, and boulders are present in lesser amounts. Yields of a few to several hundred gallons per minute are available from these rocks. The water will contain about $200-2,000 \mathrm{ppm}$ dissolved solids.

Alluvium in the valleys of Fivemile, Muddy, and Cottonwood Creeks is relatively fine grained. Sand and silt are predominant; clay, gravel, and cobbles are present in lesser amounts. Yields of a few gallons per minute are available from some of these rocks. The water from most of these rocks probably contains about 1,000-2,000 ppm dissolved solids.

\section{CHEMICAL QUALITY OF WATER}

Chemical analyses of $1+6$ ground-water samples are giver in table 6 . In addition to the data in the table, specific conductance and dissolved solids for water from many wells are given on plate 1. Dissolved-solids data from Geological Survey analyses are not shown on plate 1 if data from other sources are available because Geological Survey analyses are given in table 6. Most of the dissolved-solids data on plate 1 are from chemical analyses made by the Wyoming State Department of Agriculture or by the U.S. Bureau of Reclamation. The specific-conductance data on plate 1 were collected in the field during this study.

Chemical analyses of surface waters collected at five sampling stations are giren in table 7. Locations of four of the stations are shown on plate 1; the other station is at Dubois about 10 miles west of the reservation. Additional chemical analyses of surface waters of the area have been published in Colby and others (1956) and in the annual series of water-supply papers, "Quality of Surface Waters of the United States." 


\section{W ATER-QUALITY CRITERIA}

The quality of a water is juclged according to the use for which it is needed. Generally, the lower the dissolved solids, the better the water; however, for some uses, the concentration of particular substances in a water may be even more important than the total concentration of dissolved solids. Some general criteria for evaluating water for common uses are discussed below. More detailed information may be obtained from the publications cited in the discussion.

\section{DOMESTIC AND MUNICIPAL USE}

Chemical-quality standards for potable water used by public carriers and by others subject to Federal quarantine regulations have been established by the U.S. Public Health Service (1962). These standards concern bacteria, radioactivity, and chemical constituents that may be objectionable in a water supply. The following is a partial list of the standards that pertain only to those constituents for which analyses are giren in this report:

The following chemical substances should not be present in a water supply in excess of the listed concentrations where $* * *$ other more suitab'e supplies are or can be made available. (U.S. Public Health Service, 1962)

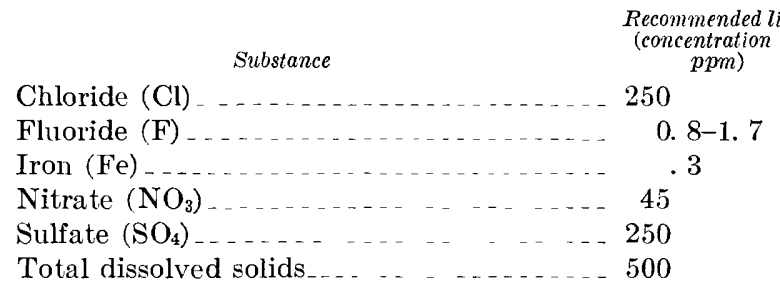

Fluoride limits are based on the arerage of maximum daily air temperatures in order to relate the limit to total consumption. For example, when the arerage is $50.0^{\circ}-53.7^{\circ} \mathrm{F}$, the upper limit is $1.7 \mathrm{ppm}$; when the average is $79.3^{\circ}-90.5^{\circ} \mathrm{F}$, the upper limit is $0.8 \mathrm{ppm}$.

Iron in water tends to stain porcelain fixtures and laundry and can be tasted. Nitrate in excess of the recommended concentration presents a potential danger if the water is used for infant feeding. Sulfate in concentrations above the recommended limit may have a laxative effect.

Excessive hardness in water is determined for domestic and municipal use and some industrial uses. It is defined as the property that causes soap to form an insoluble curd. It is also a major contributor to the scale that forms in boilers and pipes. Calcium-magnesium hardness values reported in the analyses (tables $6, \tau$ ) are approximately equivalent to the total hardness of a water. Calcium and magnesium 
cause most of the hardness of natural water; other hardness-causing constituents are generally negligible. Part of the hardness can be removed from water by heating, and an insoluble precipitate or scale is formed. The precipitate is a compound of carbonate, and that part of the hardness that is remored is called carbonate hardness. The remaining hardness is the noncarbonate hardness reported in the analyses. Methods used by the Geological Surrey to calculate hardness are given in Rainwater and Thatcher (1960). Adjectival ratings used by the Geological Survey to describe hardness are:

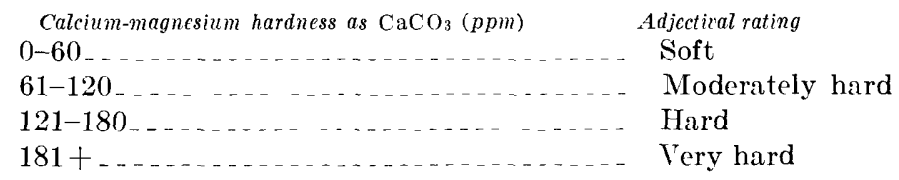

AGRICULTURAL USE

STOCK

The tolerance of animals to dissolved solids in water deponds on the species, age, and physiological condition of the animal; on the amount of water consumption; and on the quantity and type of salts present in the water. Howerer, standards for most of these factors have not been determined, and general standards based on the total concentration of dissolved solids are used. McKee and Wolf (1963) discuss some of the criteria that hare been used. Beath and others (1953) suggest the following classification as a guide for eraluating stock water in Wyoming.

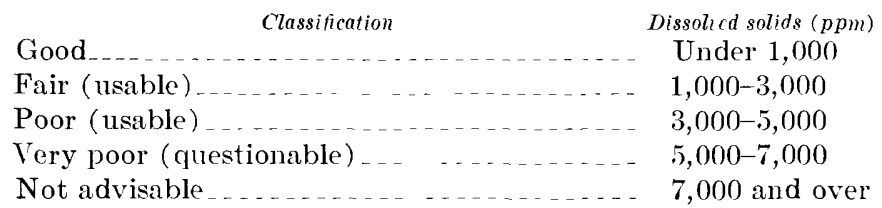

IRRIGATION

Boron, bicarbonate, sodium, and salinity are the principal hazards related to the chemical character of water for irrigation use.

Boron is an essential plant nutrient, but even rery low concentrations may be toxic to boron-sensitive crops. Eaton (1935) has classified crops according to their tolerance to boron. For boron-sensitive crops, concentrations of less than about $0.7 \mathrm{ppm}$ have very slight effect; higher concentrations hare significant yield depression or may be unusable. For tolerant crops, concentrations of less than 2.0 ppm hare reery slight effect (Scofield, 19:36).

When bicarbonate concentrations are high, calcium and magnesium tend to precipitate as carbonates. The calcium-magnesium concentra- 
tion is thereby reduced, and the relative proportion of sodium is increased.

When the sodium concentration in water is high compared with that of calcium and magnesium, sodium replaces calcium and magnesium in the soil and a sodium soil remains. Sodium soils may be improved by adding amendments, such as gypsum, which replenish the calcium or magnesium. An index of the sodium hazard is the sodium-adsorptionratio (SAR) which expresses the relative activity of sodium ions in the exchange reactions with soil (U.S. Salinity Lab. Staff, 1954).

Salinity (dissolved solids) increases the osmotic pressure in the soil solution, and when salinity is high, plant growth is retarded. Because the salinity of water is closely related to the specific conductance of water, specific conductance may be used as a measure of the salinity hazard of water.

Specific conductance and SAR for water from alluvium are plotted (fig. 15) on a diagram (U.S. Salinity Lab. Staff, 1954) that is used for classification of water for irrigation. Other water may be classified in the same manner by use of this diagram. The water is classified according to salinity and sodium hazards as follows:

\section{Salinity hazard}

Class

1. Low-salinity water can be used for irrigation of most crops on most soils, with little likelihood that a salinity problem will develop. Some leaching is required, but this occurs under normal irrigation practices except in soils of extremely low permeability.

2. Medium-salinity water can be used if a moderate amount of leaching occurs. Plants with moderate salt tolerance can be grown in most instances without special practices for salinity control.

3. High-salinity water cannot be used on soil with restricted drainage. Even with adequate drainage, special management for salinity may be required and plants with good salt toleranse should be selected.

4. Very high salinity water is not suitable for irrigatior under ordinary conditions, but may be used occasionally under very special circumstances. The soil must be permeable, drainage must be adequate, irrigation water must be applied in excess to provide considerable leaching, and very salt tolerant crops should be selected. 
WIND RIVER INDIAN RESERYATION, WYOMING

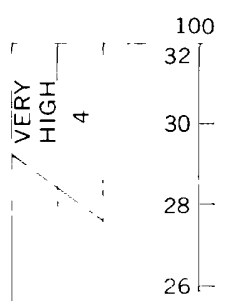

$\frac{I}{I} m \quad 24-$
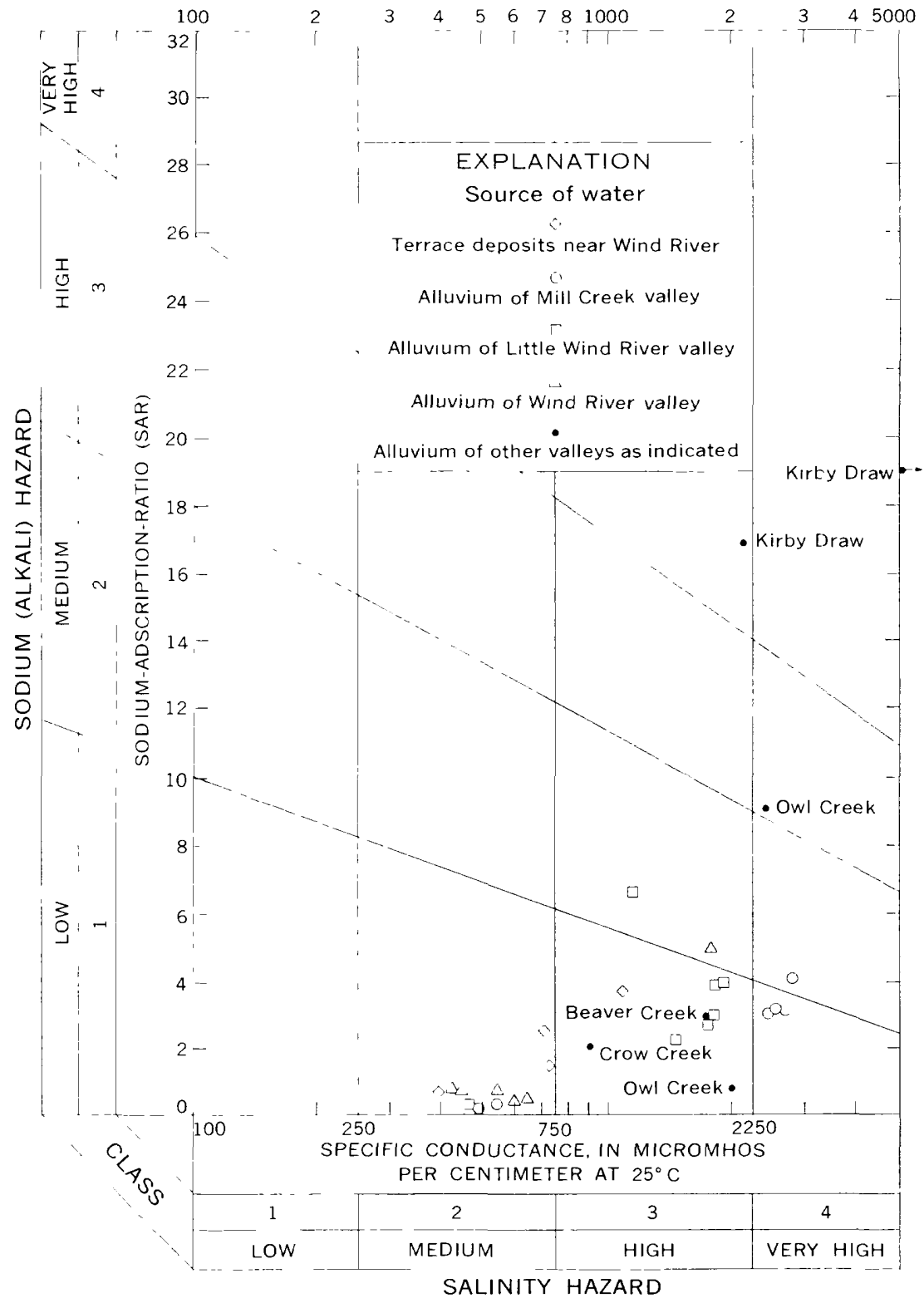

Frgure 15.-Classification of water from alluvium for irrigation use. Diatgram adapted from U.S. Salinity Laboratory Staff, 1954. 


\section{Sodium hazard}

Class

1. Low-sodium water can be used for irrigation on almost all soils with little danger of the development of a sodium problem. Sodiumsensitive crops, howerer, may accumulate injurious amounts of sodium in the leares.

2. Medium-sodium water may present a moderate sodium problem in fine-textured (clay) soils unless there is gypsum in the soil. This water can be used on coarse-textured (sandy) or permeable organic soils.

3. High-sodium water may produce troublesome sodium problems in most soils and will require special management, good drainage, high leaching, and additions of organic matter. If there is plenty of gypsum in the soil, a serious problem may not develop for some time. If gypsum is not present, it or some similar material may have to be added.

4. Very high sodium water is generally unsatisfactory for irrigation except at low- or medium-salinity levels where the use of gypsum or some other amendment makes it possible to use such water.

\section{INDUSTRIAL USE}

Water-quality criteria for industrial use vary widely according to use. Some industries have strict quality requirements. Requirements for cooling and waste disposal are generally lenient, although certain waters may require treatment to prevent corrosion and scale. Criteria for many industrial uses are given in McKee and Wolf (1963, p. $92-106)$.

\section{QUALITY OF SURFACE WATER}

The Geological Survey maintains sampling stations near Dubois on the Wind River (about 10 miles west of the reservation), near Riverton on the Wind and Little Wind Rivers, near Arapahoe on the Little Wind River, and near Hudson on the Popo Agie River. Dissolved solids in the Wind River near Dubois range from about 50 to $300 \mathrm{ppm}$ (Colby and others, 1956). The Wind River at Riverton contains a calcium bicarbonate water that is moderately hard to hard; dissolved solids range from about 150 to $350 \mathrm{ppm}$. Analyses show an appreciable increase in sulfate downstream from Dubois. Much of the water from the Wind River is diverted for irrigation on the Riverton Irrigation Project, but the return flow is discharged into the river by way of Fivemile Creek downstream from the sampling station at Riverton.

Dissolved solids in the Little Wind River near Riverton range from about 300 to $850 \mathrm{ppm}$; water in the Popo Agie River near Hudson is 
probably similar, but water in the Little Wind River above Arapahoe has a high concentration of dissolved solids. Water from these streams is used extensively for irrigation, and much of their flow in downstream reaches during the irrigation season is return flow from irrigation.

Fivemile Creek is used as a drain for the Riverton Irrigation Project. The surplus irrigation water and seepage of ground water from the irrigated land has made the formerly intermittent stream a perennial stream. The water is a sodium sulfate type, very hard, and dissolved solids range from about 1,000 to 4,000 ppm (Colby and others, 1956).

\section{QUALITY OF GROUND WATER}

Most of the geologic formations in the area have few, if any, wells, and little or no data are available concerning the quality of the ground water in them. A relatively large amount of data is available concerning the quality of the water in the Wind River Formation and in some of the alluvinm. Chemical-quality data are presented in table 6 and on plate 1. General estimates of the dissolved solids that may be expected in water from the formations are included with the discussion of the geologic units in the text and in table 1.

\section{DRAINAGE PROBLEMS IN IRRIGATED ARFAS}

\section{HISTORY OF IRRIGATION}

Irrigation began in the early 1860 's with simple diversions of water from the Popo Agie and Little Wind Rivers. In 1905 the Wind River Irrigation Project was established on lands under supervision of the Bureau of Indian Affairs. The Wyoming No. 2 canal was built near Riverton in 1907 on land ceded by the Indians. About 1914 the Riverton-Le Clair Irrigation District was formed. In 1920 the Bureau of Reclamation began construction of the Riverton Irrigation Project in the Fivemile Creek drainage; the project was expanded in 1951 to include areas in the Muddy Creek drainage. (See locations of projects and irrigated areas on pl. 3.)

Irrigation began about 1880 in the Owl Creek valley. Several unsuccessful attempts have been made to augment and stabilize the supply of water in Owl Creek, but irrigation in the valley ramains dependent on uncontrolled runoff supplemented to a small degree by ground water.

More detailed information on the history of irrigation in the Wind River Reservation can be found in Gerharz (1949), T.S. Bureau of Indian Affairs (1962), and U.S. Bureau of Reclamation (1950). 


\section{AREAS OUTSIDE THE WIND RIVER IRRIGATION PROJECT}

The discussion of drainage problems is confined to those of the Wind River Irrigation Project, which is under the supervision of the Bureau of Indian Affairs. Other irrigated areas are under the supervision of individuals, private irrigation districts, or the Bureau of Reclamation.

Much detailed work has been done by the Bureau of Reclamation in the study and control of drainage and related problems in the Riverton Irrigation Project. Some work has also been done in the RivertonLe Clair and Owl Creek Irrigation Districts. Unpublished reports and maps have been prepared by the Bureau of Reclamation. A Geological Survey report on the ground-water resources of the Rirerton Irrigation Project (Morris and others, 1959) contains a discussion of drainage problems.

\section{AREAS IN THE WIND RIVER IRRIGATION PROJECT}

\section{PREVIOUS DRAINAGE STUDIES}

The first recorded drainage canal on the Wind River Irrigation Project was constructed about 1918. The first comprehensive drainage plan, presented by Gerharz (1949), included the location and design of proposed drainage facilities. The plan was based or topographic mapping of problem areas and on some subsurface investigation.

A more detailed drainage investigation was conducted from 1960 to 1965 by Missouri River Basin Investigations (U.S. Bur. Indian Affairs, 1965). Drainage-problem areas of the Left Hand unit, tre flood plains of the Sub-Agency system near Arapahoe, the underfit-stream valleys of Mill and Trout Creeks, and the area just east of Ray Lake (pl. 3) were intensely studied and drainage facilities were proposed. Holes were augered in a grid pattern approximately every eighth of a mile, and pipes were installed approximately every quarter of a mile to observe water levels. Hole depths were 9-14 feet (lengths of the auger stem), except where coarse deposits limited augering to shallower depths. Maps were constructed showing the depth to gravel based on auger data. Water levels were measured frequently, and maps were prepared showing water-table conditions at various times during both irrigating and nonirrigating seasons for the years 1961 through 1963. The maps show the depth to water and water-table and land-surface contours. In addition to the areas of intensive study, the investigation included a reconnaissance of the other drainage-problem areas in the Wind River Irrigation Project.

Soil studies have been made, and the lands have been mapped and classified. One such study was made for the Branch of Land Operations 
as a part of a resource inventory of the reservation (U.S. Bur. Indian Affairs, 1962).

Two reports are now in preparation concerning the Wind River Irrigation Project in general and will include information on drainage. "The WVind River Irrigation Project Completion Report," is in preparation by Missouri River Basin Investigations. The "Report on the Wind Division, Wyoming," is in preparation by the Bureau of Reclamation and will include relations of the Wind River Irrigation Project to other existing or proposed developments in the Wind River Basin.

\section{METHODS FOR IMPROVING DRAINAGE}

Methods commonly used to improve drainage are discussed in detail in publications on drainage engineering such as that by Luthin (1957). Methods that are, or could be, used in relieving drainage problems in the IVind River Irrigation Project include the reduction of applied water and the use of drains or wells to remove excess water.

Open drains about 8 feet in depth are used to lower water tables; they increase gradients locally and provide channels for water transport. They are also used to intercept the lateral movement of ground water. Shallower drains, less than $t$ feet in depth, are in use in some parts of the area, but they have a limited effect on the water table. Buried drains increase gradients, provide channels for water transport, and have the general effect of increasing the permeability of the material in which they are buried.

Relief wells can be used to make drains more effective where deposits of low permeability extend below practical drain depths but overlie more permeable gravel. The relief wells are constructed in the bottom of drains and are drilled into the underlying gravel. They provide a direct hydraulic connection between the drain and the gravel, and water flows from the wells into the drains.

Pumping from wells can lower the water table and drain waterlogged areas where geologic conditions are suitable. Pumping from sumps or from drains can be used effectively to move water from a waterlogged area, and they can be particularly useful where the gradient between the waterlogged area and the ultimate surface drainage is flat and conditions are not favorable for pumping from wells. The water obtained by pumping would be arailable for irrigation, and the amount of surface water used could be reduced.

Reduction of the amount of water entering an area may be essential in some areas. The lining of canals and ditches and the reduction of irrigation-water applications to an optimum would relieve the load on the drainage system. 


\section{CLASSIFICATION AND EVALUATION OF DRAINAGE-PROBLEM} AREAS

The present study is limited chiefly to the relation of drainage problems to geology. Most irrigated lands are unconsolidated slope wash or stream deposits underlying flood plains, terraces, or gentle slopes. Test holes were drilled through these deposits to define their composition and thickness. Sections at nine locations are shown on plate 3 . On the basis of the test drilling, the alluvium was divided into coarse-grained allurium and fine-grained alluvium. The coarsegrained alluvium consists of sand, gravel, cobbles, and boulders and contains very little silt or clay; it generally lies on the bedrock. The fine-grained alluvium grades from a silty soil zone formed on sand and gravel of flood plains and terraces to slope wash of clay, silt, and sand.

Terms used to describe permeability in the discussion of the drainage problems have arbitrarily been given the values: "Low," less than $10 \mathrm{gpd} / \mathrm{ft}^{2}$; "moderate," 10-100 gpd/ft"; and "high," greater than 100 $\mathrm{gpd} / \mathrm{ft}^{2}$.

Areas of the Wind Rirer Irrigation Project where drainage problems occur were mapped by the U.S. Bureau of Indian A ffairs (1965) and are shown on plate 3 . For this report, the drainage-problem areas have been classified according to geologic similarities into five general groups: flood plains, terraces, underfit-stream ralleys, slopes, and transitional areas.

\section{FLOOD PLAINS}

Many of the drainage-problem areas occur on the flond plains and related low terraces in the river valleys. In these areas, highly permeable coarse-grained alluvium underlies fine-grained alluvium of low to high permeability. Downstream land-surface gradients range from

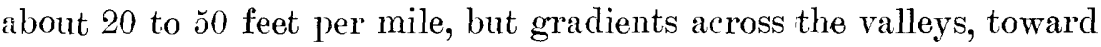
the rivers, are generally less than 5 feet per mile. The water-table gradient is approximately parallel to that of the land surface; accordingly, most ground-water movement is parallel to the rirer rather than toward it. Water tables are naturally high, and some of the area was probably waterlogged before addition of irrigation water. The problem is aggravated in some areas where water from terrace deposits discharges into the flood-plain deposits.

\section{LEFT-HAND UNIT}

As section $\mathrm{A}-\mathrm{A}^{\prime}$ and $\mathrm{B}-\mathrm{B}^{\prime}$ (pl. 3) show, the land surface of this area is about $5-8$ feet above the lerel of the Wind and Little Wind Rivers. The water table ranges from the land surface to a depth of about 8 feet. The total thickness of the alluvium is 10-1.5 feet in most 
of the area. It consists of highly permeable coarse-grained alluvium overlain by 6 feet, or less, of moderately to highly pern eable finegrained alluxium.

Barriers of low permeability probably contribute to the drainage problems in some areas, but the principal problems are the low gradient and the naturally high water table. Left-Hand Canal and its distribution ditches are unlined and add water to the alluvium. Springs, which are visible along the terrace scarps in several places, are evidence that the irrigated terraces to the south contribute some water.

The alluvium is underlain by siltstone and sandstone of the Wind River Formation. Water in the sandstone in contact with the allivium is hydraulically connected to the water table in the alluvium. Some deeper sandstones have piezometric heads about the water table, which suggests the possibility that the bedrock could contribute some water to the alluvium. Generally, however, layers of relstively impermeable siltstone separate the deeper standstones from the alluvium. Water from the bedrock probably has no significant effect on the drainage problems.

Drainage problems would be alleriated by reducing the amount of water entering the area. Steps that would improve drainage include the lining of canals and ditches and the reduction of irrigation-water applications to the optimum. Drains would be effective for intercepting canal losses, but would be only partially effective in lowering the water table because of flat gradients across the valley.

The use of wells to aid drainage does not seem feasible because of the thinness of the alluvium. A pumping test on well $A 1-4-31 \mathrm{dcc}$ showed a maximum yield of about $5 \mathrm{gpm}$. (See discussion on test under "Aquifer characteristics.") A much larger yield would be necessary to lower the water table significantly. Pumping from sump pits or from drains, however, could produce larger discharges and, if pumped into a lined canal system, the water table could be lowered. Ground water recovered from the area would probably be suitable for irrigation or, if marginal in quality, could be diluted with surface water and used.

\section{JOHNSTOWN UNIT}

In the problem area shown in section $C-C^{\prime}$ (pl. 3), the land surface is generally about 10 feet above the river level. The water table in the problem area ranges from the land surface to a depth of about 10 feet. The total thickness of the alluvium is about $25-30$ feet. About 20 feet of highly permeable coarse-grained alluvium underlie 5-10 feet of finegrained alluvium, which is mostly of moderate permeability. The other problem area in this unit (pl. 3) is apparently rery similar. 
The alluvium is underlain by siltstone, sandstone, and conglomerate of the Wind River Formation. Coarse-grained sandstone and conglomerate, which are moderately to highly permeable, are at places directly in contact with the allurium as at well A1-2-6aaa. In this area, water movement is from the alluvium to the bedrock, as the water table of section $C-C^{\prime}$ (pl.3) shows.

Drains should be effective in improving drainage. Where practical, the drains should penetrate the coarse-grained alluvium or be hydraulically connected to it with relief wells. The lining of Johnstown canal would be desirable, but section $C-C^{\prime}$ (pl. 3) indicates that a drain along the south edge of the drainage-problem area would intercept much of the canal losses.

Wells could be used as an alternative or supplement to drains. A battery of wells tapping the coarse-grained alluvium should lower the water table effectively and would yield water suitable for irrigation.

UPPER WIND UNIT

In the problem area shown in the northern part of section $D-D^{\prime}$ (pl. 3 ), the land surface ranges from 5 to 50 feet above the river level. Water-level data are sparse, but the water table is known to rise to the land surface in parts of the area during the irrigation season. Watertable fluctuations are probably large in the southern part of the problem area. The total thickness of the alluvium ranges from about 40 to 90 feet. About 40-70 feet of highly permeable coarse-grained alluvium underlie fine-grained alluvium. The fine-grained alluvium ranges in thickness and in character from about 1 foot of highly permeable soil in the northeast to about 30 feet of slope wash and alluvial-fan deposits of low to moderate permeability in the southwest. The other problem areas along the flood plain in the Upper Wind unit (pl. 3) are probably very similar.

Ground-water movement is predominantly down the valley, but water also moves laterally into the valley from the streams, draws, and terraces draining from the southwest. Bedrock should have no significant effect on the drainage problems. Drainage problems result from the abundance of surface water, from the low permeability of the surface deposits in the southwest, and from low land near the river in the northeast.

Drains would be effective in some of the area, and wasteways to divert surface flows would be helpful. Wells could produce irrigation supplies of good quality and help lower the water table. (See discussion of test of well B4-4-2cda under "Aquifer characteristics.") Water from canals and irrigation applications are a significant source of the excess water. If ground water from wells were used for irrigation and 
imported water were reduced to a minimum, many drainage problems would be alleviated.

\section{SUB-AGENCY SYSTEM, LITTLE WIND UNIT}

In the problem area, shown in sections $F-F^{\prime}$ and $G-G^{\prime}$ (pl. 3), the land surface is generally about 10 feet above the river level. The water table ranges from the land surface to a depth of about 10 feet, but is less than 5 feet below land surface in most of the area. The total thickness of the alluvium ranges from about 5 to 20 feet. Highly permeable coarse-grained alluvium underlies about 5 feet, or less, of f ne-grained alluvium of low to moderate permeability. The other problem area of the flood plain in the Sub-Agency system (pl. 3) is probably very similar.

Ground-water morement is both toward the river and down the valley. Part of the excess ground water in the valley drains from irrigated terraces on the north and part is from local irrigation.

The alluvium is underlain by siltstone and sandstone of the Wind River Formation. Water in the sandstone in contact with the alluvium is hydraulically connected to water in the alluvium. Some deeper sandstones have piezometric heads above the water table. Generally, however, layers of relatively impermeable siltstone separate the deeper sandstones from the alluvium. Water from the bedrock probably has no significant effect on the drainage problems.

Drainage problems would be alleriated by reducing the amount of water entering the area, particularly that water draining from the higher irrigated terraces to the north. Intercept drains along the base of the terrace scarp would be helpful. Flat gradients across the valley, however, would seriously limit the usefulness of drains in most of the area. Other steps that would improve drainage include the lining of canals and ditches and the reduction of irrigation-water applications to the optimum.

The use of wells to aid drainage does not seem feasible because of the thinness of the allurium in most of the area. Pumping from sump pits or drains, however, would lower the water table and would make drains more effective. Ground water recovered from the area would generally be of poor quality for irrigation, but could be used by diluting with surface water.

COOLIDGE SYSTEM, LITTLE WIND UNIT

In the problem area near Ethete shown in section $H-I^{\prime}$ (pl. 3), the land surface is about 15 feet above the river level. The dep+h to water is less than 5 feet in most of the area. The total thickness of the alluvium ranges from about 15 to 30 feet. About 15-25 feet, of highly 
permeable coarse-grained alluvium underlie about 5 feet, or less, of fine-grained alluvium of low to moderate permeability.

Ground-water movement is both toward the river and down the valley. The water table rises in the drainage-problem areas in response to applied irrigation water and leakage from ditches. Contribution of water from the bedrock, if any, is probably not significant to the drainage problems. The bedrock is shale and sandy shale of the Cody Shale. Section $H-H^{\prime}$ (pl. 3) arbitrarily shows the base of the coarsegrained alluvium as the contact with the Cody. A zone of clay underlying the coarse-grained alluvium generally could not be distinguished from weathered shale of the Cody.

Drains penetrating the coarse-grained alluvium should bo effective. Wells could produce water suitable in quality for irrigation and effectively lower the water table. (See discussion of test of well A1-1-34bcb under "Aquifer characteristics.")

The small drainage-problem areas on the flood plains of the Little Wind River in the eastern part of the Coolidge system (pl. 3) are generally similar to the areas near Ethete. Bedrock is sandstone, siltstone, and shale of the Fort Union or Wind River Formation; bedrock probably has no significant effect on the drainage problems. Water mores laterally into the area from the Mill Creek valley. This water is much higher in dissolved solids than the water upstream in the Little Wind River valley. To be used for irrigation, water pumped from these areas would probably have to be diluted with surface water.

\section{TERRACES}

Small drainage-problem areas occur on the irrigated terraces. The alluvium underlying the terraces is similar to that underlying the flood plains. Soil zones are older and better developed, but are still moderately permeable. The terrace deposits are higher in relation to streams and are mostly well drained. Drainage problems occur where the water table is at or near the land surface because of abrupt changes in slope, changes in thickness of the alluvium, topographic lows, or local variations in permeability.

\section{UPPER WIND UNIT}

Sections $D-D^{\prime}$ and $E-E^{\prime}$ (pl. 3) show the general relation of the deposits of Crowheart terrace to the Wind River and its tributaries. The total thickness of the alluvium in the drainage-problem areas ranges from about 30 to 60 feet. About $20-50$ feet of highly permeable coarse-grained alluvium underlies about $2-15$ feet of permoable finegrained alluvium. 
The water table rises as water is applied to the land for irrigation and declines rapidly after the irrigation season as water drains from the terraces to the streams and the river valley. The terraces are mostly well drained; problem areas are small and scattered. Drains, including intercept drains along the base of slopes, should be effective in most of the areas. Wells could produce water for irrigation and help lower the water table. (See discussion of test of well P1-4-22aba under "Aquifer characteristics.")

The problem area at Burris (pl. 3), on a terrace of Dry Creek, is below the Crowheart terrace. Water draining from the Crowheart terrace probably causes most of the waterlogging. This water could be intercepted by a drain.

SUB-AGENCY SYSTEM, LITTLE WIND UNIT

The terrace deposits north of the Little Wind River near Arapahoe range in thickness from about 5 to 30 feet and are mostly 10-20 feet thick. They consist of highly permeable coarse-grained allurium overlain by fine-grained alluvium of generally moderate permeability.

The water table rises as water is applied for irrigation and declines rapidly after the irrigation season as water drains from the terraces to the Little Wind River valley. Most of the terrace deposits are well drained; problem areas are small and scattered (pl.3).

Drains penetrating the coarse-grained alluvium should ke effective. Becanse the saturated terrace deposits are generally thin, wells would probably not be rery effective in controlling drainage. Pumping into lined ditches, or canals, from sump pits or drains, however, could effectively remove water from the widely scattered drainage-problem areas, and the need for long interconnected drains could be reduced. The water could be used for irrigation if diluted with surface water.

\section{RAY SYSTEM, LITTLE WIND UNIT}

Two small problem areas south of Mill Creek have conditions similar to those described for terraces in general. The alluvium is similar to that of the Crowheart terrace in the Upper Wind unit. Most of the water is derived from irrigation. The hydrograph of well L 1-1-392dcb (fig. 4) shows the rise in water table during the irrigation season. Drains or wells should be effective in lowering the water toble.

\section{UNDERFIT-STREAM VALLEYS}

Two large drainage-problem areas are in the lower valleys of Mill and Trout Creeks. In their lower reaches, both Mill and Trout Creeks have stream channels that are small and shallow compared with the size of the valleys they occupy, and they are considered underfit 
streams. The fine-grained alluvium in the underfit-stream valleys is generally thicker and contains more slope wash than the fine-grained alluvium underlying the flood plains and terraces previously discussed.

RAY SYSTEM, LITTLE WIND UNIT

The land surface ranges from about the level of the Little Wind River to about 20 feet above the river and from about 10 feet below to 10 feet above the level of Trout Creek. (See section $I-I^{\prime}, \mathrm{pl}$. 3.) The water table ranges from the land surface to a depth of about 10 feet.

The general relations of the alluvial deposits are shown in section $I-I^{\prime}$ (pl. 3). The deposits in the northern part of the valley are rery coarse, are largely glacial outwash, and are generally well drained. They merge to the south with generally thinner and finer deposits. In the drainage-problem area near section $I-I^{\prime}$, about 2-15 fee+. of moderately to highly permeable coarse-grained alluvium underlie about $5-15$ feet of fine-grained alluvium, which is of low to moderate permeability. Upstream from section $I-I^{\prime}$, several valleys merge, and the pattern of alluvial deposition is probably more complex. Downstream, the valley narrows, and the alluvium thins where the Little Wind River passes through a gap in an anticlinal structure.

The Cody Shale underlies all except the northeastern pert of the area. Sandy shale of the Cody may contribute some water, but the effect on drainage problems is probably insignificant. In the northeast, artesian water, including that from Washakie Hot Springs, cones from the bedrock formations and may affect the drainage problems locally.

Dark-gray clay, which includes some shale-pebble gravel snd a few permeable zones, underlies the coarse-grained alluvium in some of the southern part of the valley (section $I-I^{\prime}$, pl. 3). The contact, between the clay and the underlying Cody Shale could not be distinguished; thus, the thickness of the clay is unknown, but is probably at least as thick as is indicated on section $I-I^{\prime}$. A few wells derive water from the permeable zones, but the clay probably acts generally as a barrier to downward drainage.

Ground-water movement is generally down the valley, but there is also movement toward the waterlogged area from the irrigated lands in the north-central part of the valley. North and South Forks Little Wind River act as drains, but the small streams in the southern part of the valley, including Trout Creek, probably contribute water to the waterlogged area.

Deep drains would be effective in most of the area. Where possible, the drains should penetrate the coarse-grained alluvium or be hydraulically connected to it with relief wells. Drains could be used to intercept ground water from the north and to intercept salt-laden ground 
water that moves northward from the irrigated slope wash and shale south of the valley. Wells tapping the coarse-grained alluvium could supplement the drain system; but the permeability and thickness vary, and wells would not be effective everywhere. Ground-water quality is generally better in the north and poorer in the south, but even the water of poorer quality could be used for irrigation if diluted with surface water.

\section{COOLIDGE SYSTEM, LITTLE WIND UNIT}

Both the land surface and the water table range from about the level of Mill Creek to about 60 feet above the creek. (See sectiors $J-J^{\prime}$ and $K-K^{\prime}$, pl. 3.) These relations are shown slightly distorted because the sections are not drawn perpendicular to the valley. The water table ranges from the land surface to a depth of about 15 feet.

The total thickness of the alluvium ranges from about 15 to 50 feet. About 5-30 feet of highly permeable coarse-grained alluvium underlie about $5-20$ feet of fine-grained alluvium. The fine-grained alluvium is mostly of low to moderate permeability, but contains som? sand and gravel of moderate to high permeability.

The underlying bedrock is sandstone and shale of the Frontier Formation and Cody Shale. The sections arbitrarily show the base of the coarse-grained alluvium as the contact with the bedrock. A zone of clay underlying the coarse-grained alluvium generally could not be distinguished from weathered shale, and could not be define 7 . The bedrock probably contributes a minor amount of water to the alluvium, but does not significantly affect the drainage problems.

Ground-water movement is toward and down the Mill Creek valley. One of the most important aspects of the drainage problem is the need for interception of ground water that moves into the valley from the irrigated higher lands south and southwest of Mill Creek.

Deep drains would not penetrate the coarse-grained alluvium in most places, and relief wells would be necessary to connect hydraulically the drains with the coarse-grained alluvium. Wells might be more effective than drains for much of the needed drainage. Wells could effectively lower the water table and produce water for irrigation. (See discussion of test of well D1-1-15cec under "Aquifer characteristics.") The quality of water from alluvium northwest of Mill Creek is "poor to bad" for irrigation, but could be used if diluted with surface water. Water pumped from alluvium southeast of Mill Creek would be "fair to good" for irrigation.

\section{SLOPES}

Several drainage-problem areas in the Ray and Coolidge systems, Little Wind unit, are on gentle slopes above the main valleys (pl. 3). The north ends of sections $J J^{\prime}$ and $K-K^{\prime}$ (pl. 3) cross two such areas. 
A generally thin mantle of slope wash overlies bedrock in these areas. Most of the slope wash is of low permeability, but there are some scattered thin beds of sand and gravel of moderate permeability. Nearly impermeable barriers are scattered irregularly through some of these deposits.

The slope wash is underlain by the Frontier Formation and Cody Shale. The shale, sandy shale, and sandstone of these formations generally act as a barrier to drainage, but, in some places, bedrock may be a source of water. Irrigation water, canal leakage, and possibly artesian flows from the bedrock add water to the slope wash at rates faster than the material can transmit the water. Much of the waterlogged area is above the principal water table, but perched water accumulates during the irrigation season. Much of this perched water evaporates and leaves a concentration of salts in the soil. Drainage would be difficult in most of these areas, but drains that would intercept water below canals or other sources of water would reduce the size of the waterlogged areas.

Slope deposits grade from the slope wash described above to nearly impermeable clay or weathered shale, which cannot be drained ac'equately and are usually not irrigated. Material underlying the area in the eastern part of the Coolidge system, secs. 17 and 18, T. 1 S., R. 2 E. (pl. 3), is nearly impermeable (U.S. Bur. of Indian Affairs, $1965)$.

\section{TRANSITIONAL AREAS}

Several small drainage-problem areas grade from slope wash over bedrock to slope wash orer coarse-grained allurium. Although details of these areas are unknown, conditions are generally similar, in part, to those of both the underfit-stream ralleys and the slopes. Drains could be used where underlying coarse-grained alluvium is present, but most of these areas would be difficult to drain.

\section{POTENTIAL USE OF UNDERGROUND STORAGE}

As yet, underground storage of water for irrigation supplies has not been utilized, except to a rery small degree in the Owl Creek ralley. A large volume of water is stored in alluvium along the Wind River, Little Wind River, and Mill Creek; lesser rolumes are stored in deposits underlying irrigated terraces and in alluvium in some of the smaller stream valleys. The water in these deposits is astually in transient storage, that is, the water is moving through the deposits at a fairly slow rate; but at any particular time the deposits contain a certain amount of water. The underground storage could be utilized by pumping ground water from the allurium during the irrigation season. Water remored by pumping would erentually be replaced by 
infiltration of precipitation, streamflow, and irrigation water. The process would be somewhat analogous to the way water in a surfacestorage facility is used and is erentually replenished by streamflow.

The amount of water that is available from storage is the product of the volume of the saturated deposits and the specific yield of the deposits. The rolume of the allurium is known in a few areas that have been test drilled. The specific yield is unknown, but a specific yield of 10 percent is probably conservative for the type of deposits discussed. In the area along the Wind River near Crowheart (north end of section $D-D^{\prime}$. pl. 3) saturated coarse-grained alluvial deposits are about 40 feet thick and 11/2 miles wide. Using 10 percent as spesific yield, about 4,000 acre-feet of water is available from storage for each mile length of the valley. Near Riverton (section $B-B^{\prime}$, pl. 3), where saturated coarse-grained deposits average about 8 feet in thickness and a little more than 1 mile in width, about 500 acre-feet of water is available from storage per mile length of the valley. Near Ethete (section $H-H^{\prime}$, pl. 3 ), where saturated coarse-grained deposits are about 20 feet thick and $11 / 2$ miles wide, about 2,000 acre-feet of water is available from storage per mile length of the valley. In the Mill Creek valley (sections $J-J^{\prime}$ and $K-K^{\prime}$, pl. 3 ) the saturated coarse-grained deposits a verage about 15 feet in thickness, and about 1,000 acre-feet of water are available from storage for each square mile.

These values are intended only to give an estimation of the amount of water available in underground storage. Not all this water would be usable because it would be impractical to pump the deposits dry.

The use of both surface and underground storage of water could reduce the need for additional surface storage in some areas. Careful water management would be required because of the close relation of streamflows to the ground water; heavy pumping could divert entire streamflows. Overall planning would be required to make available the most water at the right time and at the least cost.

Both surface and underground storage are means of storing water, not of producing new supplies. The only increase in total water available would be by reduction of eraporation from open-water surfaces and from the water table in waterlogged areas. If underground storage were used rather than surface storage, the water that would have evaporated from that open surface would be salvaged. Lowering water levels in waterlogged areas by pumping would reduce eraporation from the water table. No estimate has been made of the possible amount of water retained by minimizing evaporation, but it would probably be significant. 


\section{SUMMARY}

Most wells in the area derive water from the Wind River Formation and the alluvium; consequently, hydrologic properties of these rocks are better known than those of other rocks. The range of permeability is estimated to be about 1-220 $\mathrm{gpd} / \mathrm{ft}^{2}$ for water-bearing sandstone of the Wind River Formation and about $150-7,500 \mathrm{gpd} / \mathrm{ft}^{2}$ for the alluvium.

Geologic units having the largest potential for development of ground-water supplies are the Bighorn Dolomite, Madison Limestone, Tensleep Sandstone, Crow Mountain Sandstone, Nugget Sandstone, Sundance Formation, Cloverly and Morrison Formations, Mesaverde Formation, Lance(?) Formation, Fort Union Formation, Wind River Formation, and the alluvium. Descriptions of these and other geologic units in the area are tabulated (table 1) along with estimates of the potential water supply from the rocks and the probable concentration of dissolved solids.

Many parts of the Wind River Irrigation Project have become waterlogged. The drainage-problem areas are classified according to geologic similarities into five general groups: flood plains terraces, underfit-stream valleys, slopes, and transitional areas. Local geologic and hydrologic conditions indicate the type of drainage facilities that would be successful.

Water from underground storage in alluvium could supplement water from surface storage in some areas. The use of both surface and underground storage would reduce the need for additional surfacestorage facilities and also would alleriate drainage problems in the irrigated areas.

\section{SELECTED REFERENCES}

Agatston, R. S., 1957, Pennsylvanian of the Wind River Basin, in Wyoming Geol. Assoc. Guidebook 12th Ann. Field Conf., 1957 : p. 29-33.

Andrews, D. A.. 1944. Geologic and structure contour map of the Maverick Spring area, Fremont County, Wyoming: U.S. Geol. Surrey Oil and Gas Inv. (Prelim.) Map OM-13.

Beath, O. A., Gilbert, C. S.. Eppson, H. F.. and Rosenfeld, Irene, 1953 Poisonous plants and livestock poisoning: Wroming Agr. Expt. Sta. Bull. 324, 94 p.

Bentall. Ray, compiler. 1963. Methods of determining permeabilits. transmissibility, and drawdown: L.S. Geol. Survey Water-Supply Paper 1536-I. 341 p.

Berry, D. W., and Littleton, R. T., 1961. Geology and ground-water resources of the Owl Creek area, Hot Springs County, Wroming: U.S. Geol. Survey Water-Supply Paper 1519, 58 p.

Branson, E. B., and Branson, C. C.. 1941. Geology of the Wind River Mountains, Wyoming: An. Assoc. Petroleum Geologists Bull, v. 25, no. 1, p. 120-151.

Burk, C. A., Chm., 1956, Subsurface stratigraphy of the pre-Niobrara formations in the Wind River Basin, central Wyoming, Pt. 1, of Wyoming Stratigraphy : Wyoming Geol. Assoc., Nomenclature Committee, p. 23-33. 
Burk, C. A.. 1957, Stratigraphic summars of the nonmarine upper Jurassic and lower Cretaceous strata of Wyoming. in Wyoming Geol. Assoc. Guidebook 12 th Ann. Field Conf., $1957:$ p. $55-62$.

Case, J. E., and Keefer, W. R., 1966, Regional gravity survey, Wind Piver Basin, Wroming, in Geological Survey Research, 1966: U.S. Geol. Survey Prof. Paper 550-C, p. C120-C128.

Cohee, G. V., chm.. 1961, Tectonic map of the United States exclusive of Alaska and Hawaii : C.S. Geol. Survey and Am. Assoc. Petroleum Geologists. 2 sheets, scale $1: 2,500.000$.

Colby, B. R., Hembree, C. H., and Rainwater, F. H., 1956, Sedimentation and chemical quality of surface waters in the Wind River Basin, Wyoming: U.S. Geol. Surves Water-Suppls Paper 1373, 336 p.

Crawford, J. G., 1940, Oil-field waters of Wyoming and their relation to geological formations: Am. Assoc. Petroleum Geologists Bull., v. 24, no. 7, p. 1214-1329.

Crawford, J. G., 1957, Oil field waters of the Wind River Basin, in Wyoming Geol. Assoc. Guidebook 12th Ann. Field Conf., 1957 : p. 113-118.

Crawford, J. G., and Davis, C. E., 1962, Some Cretaceous waters of Wyoming, in Wyoming Geol. Assoc. Guidebook 17th Ann. Field Conf., 1962 : p. 257-267.

Duntsch, A. F., ed., 196., Crossroads of the west: Riverton, Wro., Crossroads of the West, Inc., $112 \mathrm{p}$.

Dury, G. H., 1964a, Principles of underfit streams: U.S. Geol. Survey Prof. Paper 452-A, $67 \mathrm{p}$.

Dury, G. H., 1964b. Subsurface exploration and chronologs of underfit streams: U.S. Geol. Survey Prof. Paper 452-B, 56 p.

Eaton, F. M., 1935. Boron in soils and irrigation waters and its effect on plants with particular reference to the San Joaquin Valley of California: U.S. Dept. Agriculture Tech. Bull. 448.

Fanshawe, J. R., 1939, Structural geology of Wind River Canson area. Wyoming: Am. Assoc. Petroleum Geologists Bull., r. 23, no. 10, p. 1439-1492.

Ferris, J. G., Knowles. D. B.. Brown, R. H., and Stallman, R. W., 1962, Theory of aquifer tests: U.S. Geol. Survey Water-Supply Paper 1536-E, I74 p.

Gerharz, Henry, 1949. Drainage plans for the Wind River Irrigation Project, Wind River Indian Reservation, Wyo.: U.S. Bur. Indian Affairs open-file report, $11 \mathrm{p}$.

Hadley, R. F., 1900. Recent sedimentation and erosional history of Fivemile Creek, Fremont County. Wroming: U.S. Geol. Surver Prof. Paper 352-A, 15p.

Hem, J. D., 1959, Study and interpretation of the chemical characteristics of natural water: U.S. Geol. Survey Water-Supply Paper 1473, 269 p.

Johnson, A. I., Moston, R. P., and Versaw, S. F., 1966, Laboratory study of aquifer properties and well design for an artificial-recharge site: U.S. Geol. Survey Water-Supply Paper 1615-H, $42 \mathrm{p}$.

Johnson, E. E.. Inc.. 1966, Ground water and wells: Saint Paul, Irinn., E. E. Johnson, Inc., $440 \mathrm{p}$.

Keefer, W. R., 1957. Geology of the Du Noir area, Fremont Countr, Wyoming: U.S. Geol. Survey Prof. Paper 291-E, 221 p.

Keefer, W. R., 1965a, Stratigraphy and geologic history of the unfermost Cretaceous, Paleocene, and lower Encene rocks in the Wind River Basin, Wyoming: U.S. Geol. Surves Prof. Paper $495-A, 77 \mathrm{p}$.

Keefer, W. R., 1965b, Geologic histors of Wind River Basin. central Wyoming: Am. Assoc. Petroleum Geologists Bull., r. 49, no. 11, p. 1878-1892. 
Keefer, W. R., and Rich, E. I., 1957, Stratigraphy of the Cody shale and younger Cretaceous and Paleocene rocks in the western and southern parts of the Wind River Basin, Wyoming, in Wyoming Geol. Assoc. Guidebook 12th Ann. Field Conf., 1957 : p. 71-79.

Keefer, W. R., and Troyer, M. L., 1964, Geology of the Shotgun Butte area, Fremont County, Wyoming: U.S. Geol. Survey Bull. 1157, 123 p.

Keefer, W. R., and Van Lieu, J. A,, 1966, Paleozoic formations in the Wind River Basin, Wyoming: U.S. Geol. Surrey Prof. Paper 495-B, 60 p.

King, N. J., 1959, Hydrologic data Wind River and Fifteen Mile Creek Basins, Wyoming, 1947-54: U.S. Geol. Survey Water-Supply Paper 1475-A, 44 p.

Love, J. D., 1939, Geology along the southern margin of the Absaroka Range, Wyoming: Geol. Soc. America Spec. Paper 20, $134 \mathrm{p}$.

Love, J. D., 1957, Stratigraphy and correlation of Triassic rocks in central Wyoming, in Wyoming Geol. Assoc. Guidebook 12th Ann. Field Conf., 1957: p. $39-46$.

Love, J. D., 1961, Definition of Green River, Great Divide, and Washakie basins, southwestern Wyoming: Am. Assoc. Petroleum Geologists Bull., v. 45, no. 10, p. $1749-1755$.

Love, J. D., Weitz, J. L., and Hose, R. K., 1955, Geologic map of Wyoming: U.S. Geol. Survey, scale $1: 500,000$ (about 1 in. to $8 \mathrm{mi}$.).

Lowry, M. E., 1962, Development of ground water in the vicinity of Tensleep, Wyoming: U.S. Geol. Survey open-file report, $12 \mathrm{p}$.

Luthin, J. N., 1957, Drainage of agricultural lands: Madison, Wis., Am. Soc. Agronomy, $620 \mathrm{p}$.

McKee, J. E., and Wolf, H. W., eds., 1963, Water quality criteria : California Water Quality Control Board Pub. 3A, 548 p.

Meinzer, O. E., 1923a, The occurrence of ground water in the United States, with a discussion of principles: U.S. Geol. Survey Water-Supply Paper 489, 321 p.

Meinzer, O. E., 1923b, Outline of ground-water hydrology, with definitions: U.S. Geol. Survey Water-Supply Paper 494, 71 p.

Morris, D. A., Hackett, O. M., Vanlier, K. E., and Moulder, E. A., 1959, Groundwater resources of Riverton Irrigation Project area, Wyoming: U.S. Geol. Survey Water-Supply Paper 1375, 205 p.

Murphy, J. F., 1956, Uranium-bearing water in the Crow Creek and Muskrat Creek areas, Fremont County, Wyoming: Wyoming Geol. Survey Rept. Inv. $5,15 \mathrm{p}$.

Murphy, J. F., Privrasky, N. C., and Moerlein, G. A., 1956, Geology of the SheldonLittle Dome area, Fremont County, Wyoming: U.S. Geol. Survey Oil and Gas Inv. Map OM-181.

Murphy, J. F., and Richmond, G. M., 1965, Geologic map of the Bull Lake west quadrangle, Fremont County, Wyoming: U.S. Geol. Survey Geol. Quad. Map GQ-432.

Murphy, J. F., and Roberts, R. W., 1954, Geology of the Steamboat Butte-Pilot Butte area, Fremont County, Wyoming: U.S. Geol. Survey Oil and Gas Inv. Map OM-151.

Paape, D. W., 1961, Tectonics and its influence on late Cretaceous and Tertiary sedimentation, Wind River Basin, Wroming, in Wyoming Geol. Assoc. Guidebook 16th Ann. Field Conf., 1961 : p. 187-194.

Peterson, J. A., 1957, Gypsum Spring and Sundance Formations, central Wyoming, in Wyoming Geol. Assoc. Guidebook 12th Ann. Field Conf., 1957 : p. 4754. 
Rainwater, F. H., and Thatcher, L. L., 1960, Methods for collection and analysis of water samples: U.S. Geol. Survey Water-Supply Paper 1454, 299 p.

Richmond, G. II., and Murphy, J. F., 1965, Geologic map of the Bull Lake east quadrangle, Fremont County, Wyoming: U.S. Geol. Survey Geol. Quad. Map GQ-431.

Scofield, C. S., 1936, The salinity of irrigation water: Smithsonian Inst. Ann. Rept., 1935, p. 275-287.

Sharkey, H. H. R., 1946, Geologic and structure contour map of Sage Creek Dome, Fremont County, Wyoming: U.S. Geol. Survey Oil and Gas Inv. (Prelim.) Map OM-53.

Sheldon, R. P., 1963, Physical stratigraphy and mineral resources of Permian rocks in western Wyoming: U.S. Geol. Survey Prof. Paper 313-B, 273 p.

Strickland, J. W., 1957, Summary of Mississippian and Devonian stratigraphy, Wind River Basin, Wyoming, in Wyoming Geol. Assoc. Guidebook 12th Ann. Field Conf., 1957 : p. 20-28.

Thompson, R. M., Troyer, M. L., White, V. L., and Pipiringos, G. N., 190 0 , Geology of the Lander area, central Wyoming: U.S. Geol. Survey Oil ard Gas Inv. Map OM-112.

Thompson, R. M., and White, V. L., 1954, Geology of the Riverton area, central Wyoming: U.S. Geol. Survey Oil and Gas Inv. Map OM-127.

Tourtelot, H. A., and Thompson, R. M., 1948, Geology of the Boysen area, central Wyoming: U.S. Geol. Survey Oil and Gas Inv. (Prelim.) Map OMI-91.

U.S. Bureau of Indian Affairs, 1962, Soil and range resources inventory Wind River Indian Reservation, Wyo.: U.S. Bur. Indian Affairs open-file report, $157 \mathrm{p}$.

U.S. Bureau of Indian Affairs, 1965, Drainage investigations Wind R'ver Irrigation Project, Wyoming: U.S. Bur. Indian Affairs Rept. 181.

U.S. Bureau of Reclamation, 1950, Detailed report on the Owl Creek unit, wsoming: Washington, U.S. Govt. Printing Office, $95 \mathrm{p}$.

U.S. Public Health Serrice, 1962, Drinking water standards: U.S. Public Health Service Pub. 956, 61 p.

U.S. Salinity Laboratory Staff, 1954, Diagnosis and improvement of saline and alkali soils : U.S. Dept. Agriculture Handb. 60, 160 p.

Van Houten, F. B., 1961, Tertiary geology of the Beaver Rim area, F"emont and Natrona Counties, Wyoming : U.S. Geol. Survey Bull. 1164, 99 p.

Weitz, J. L., and Love, J. D., 1952, Geologic map of southern Big Horn Basin, in Wyoming Geol. Assoc. Guidebook 7th Ann. Field Conf., 1952.

Whitcomb, H. A., and Lowry, M. E., 1967, Ground-water resources and geology of the Wind River Basin area, Wyoning: U.S. Geol. Survey Hydrol. Inv. Atlas $\mathrm{HA}-270$.

Williams, M. D., Sharkey, H. H. R., 1946, Geology of the Bargee area, Fremont County, Wyoming: U.S. Geol. Survey Oil and Gas Inv. (Prelim.) Map OM-56.

Wyoming Natural Resource Board, 1956, State of Wyoming map shoving irrigation and power development: Cheyenne, Wyoming Natural Resource Board. 


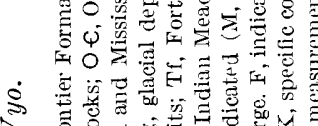

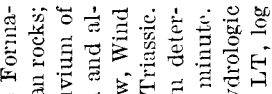

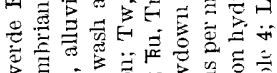

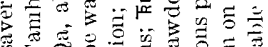

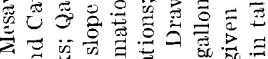

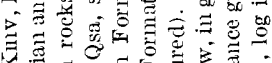

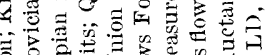

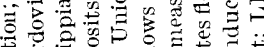

के

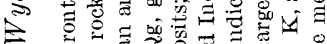

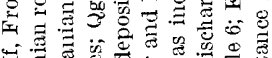

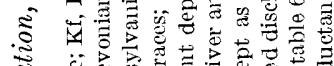

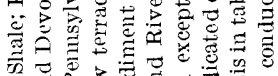

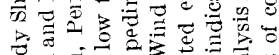

क

4 है

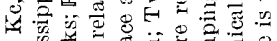

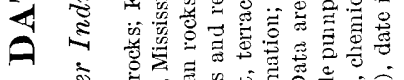

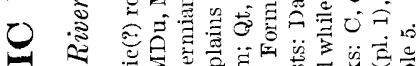

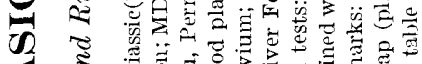

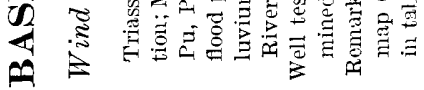

蒡

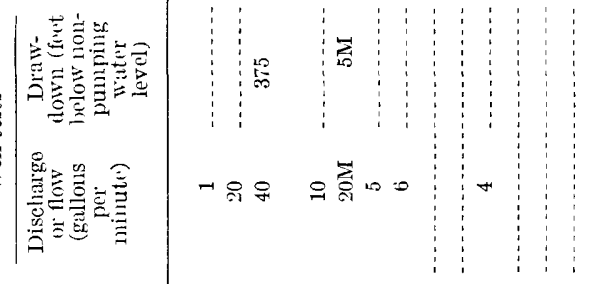

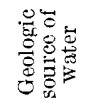

点

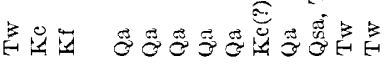

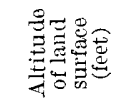

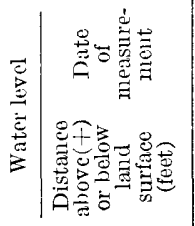

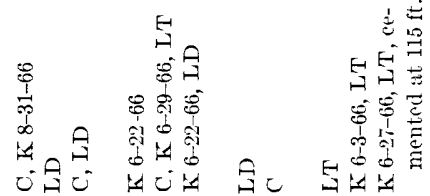

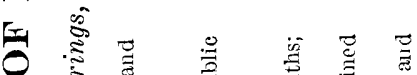

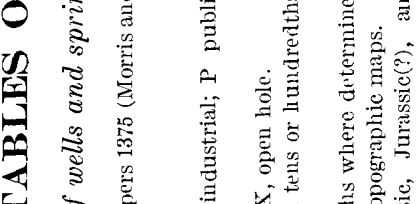

E-

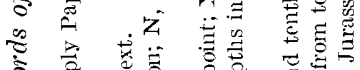

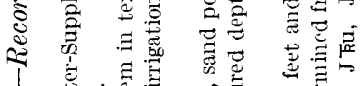

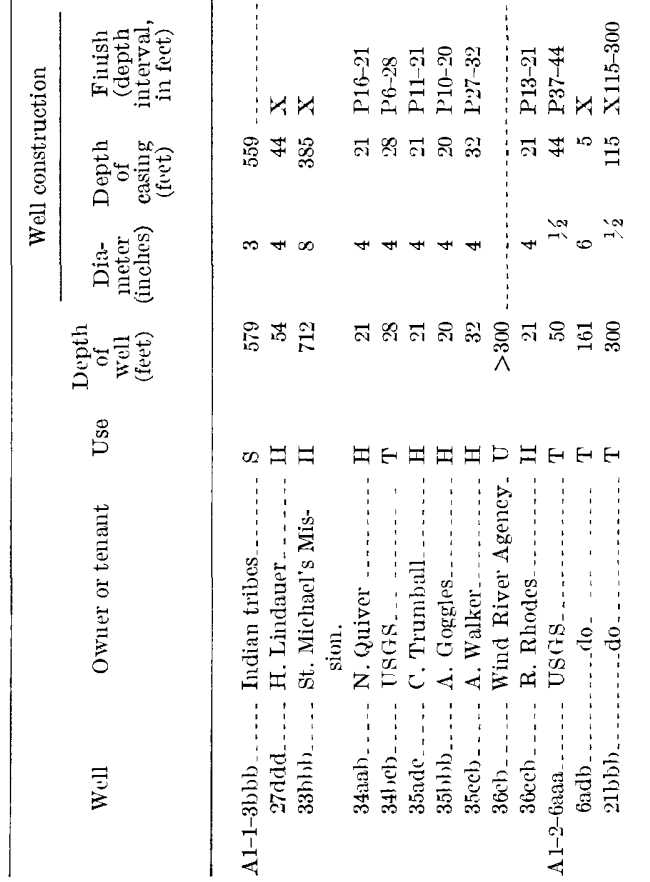

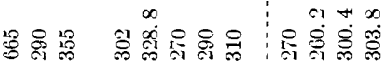

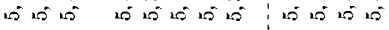

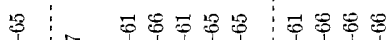

党

क ₹

要通

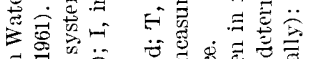

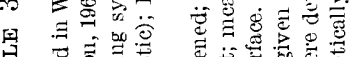

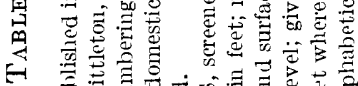

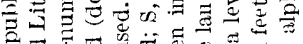

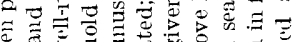

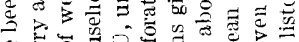

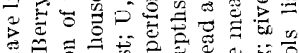

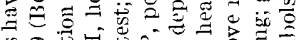

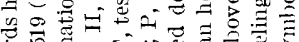

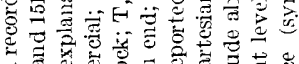

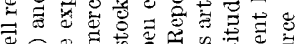

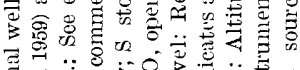

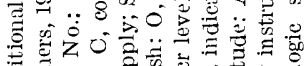

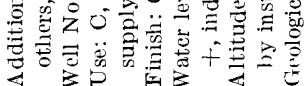




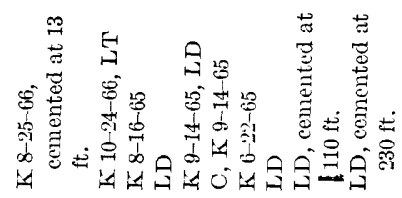

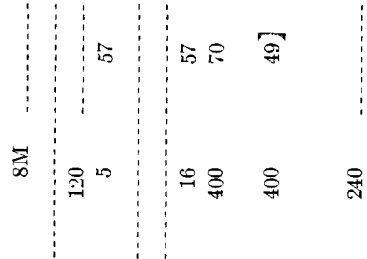

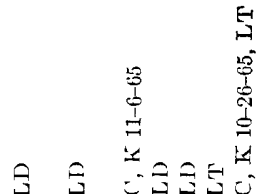

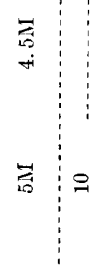

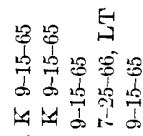

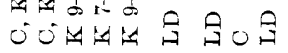

군

栗

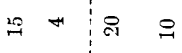

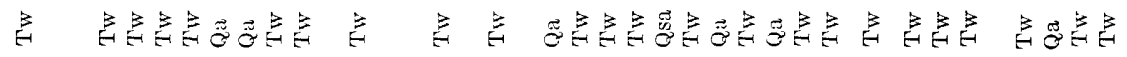

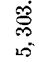

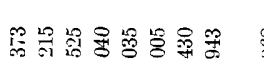

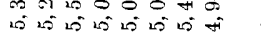

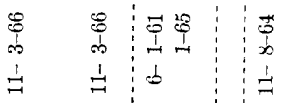

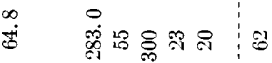

落

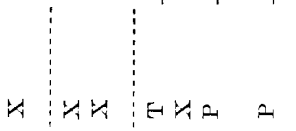

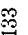

\section{$\infty$}

\section{$\infty$}

承

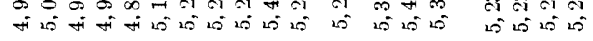

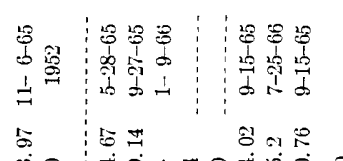

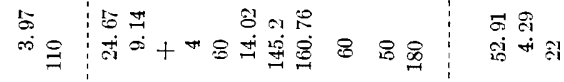

节萝

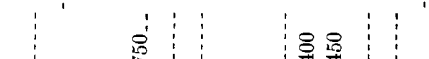

- 188

को

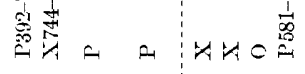

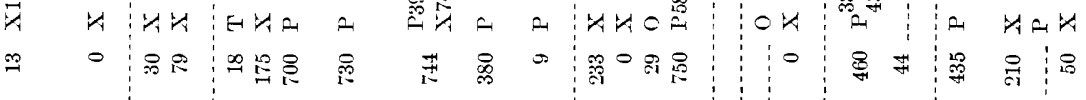

承

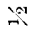

H:

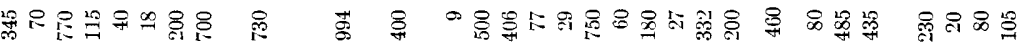

in th to

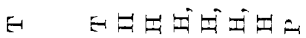

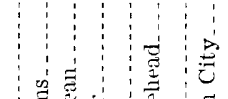

胥

$\stackrel{2}{0}$

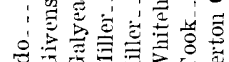

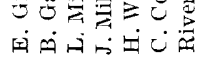

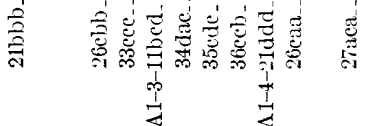

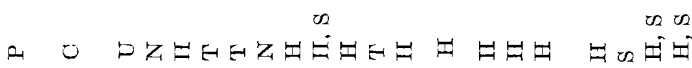

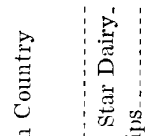

至

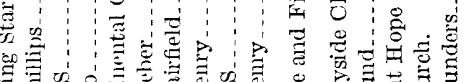

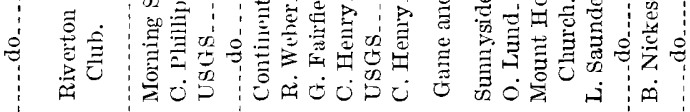

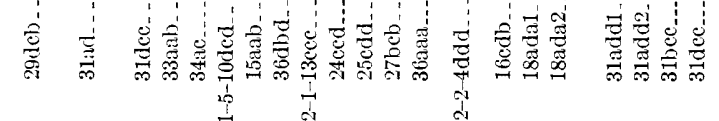




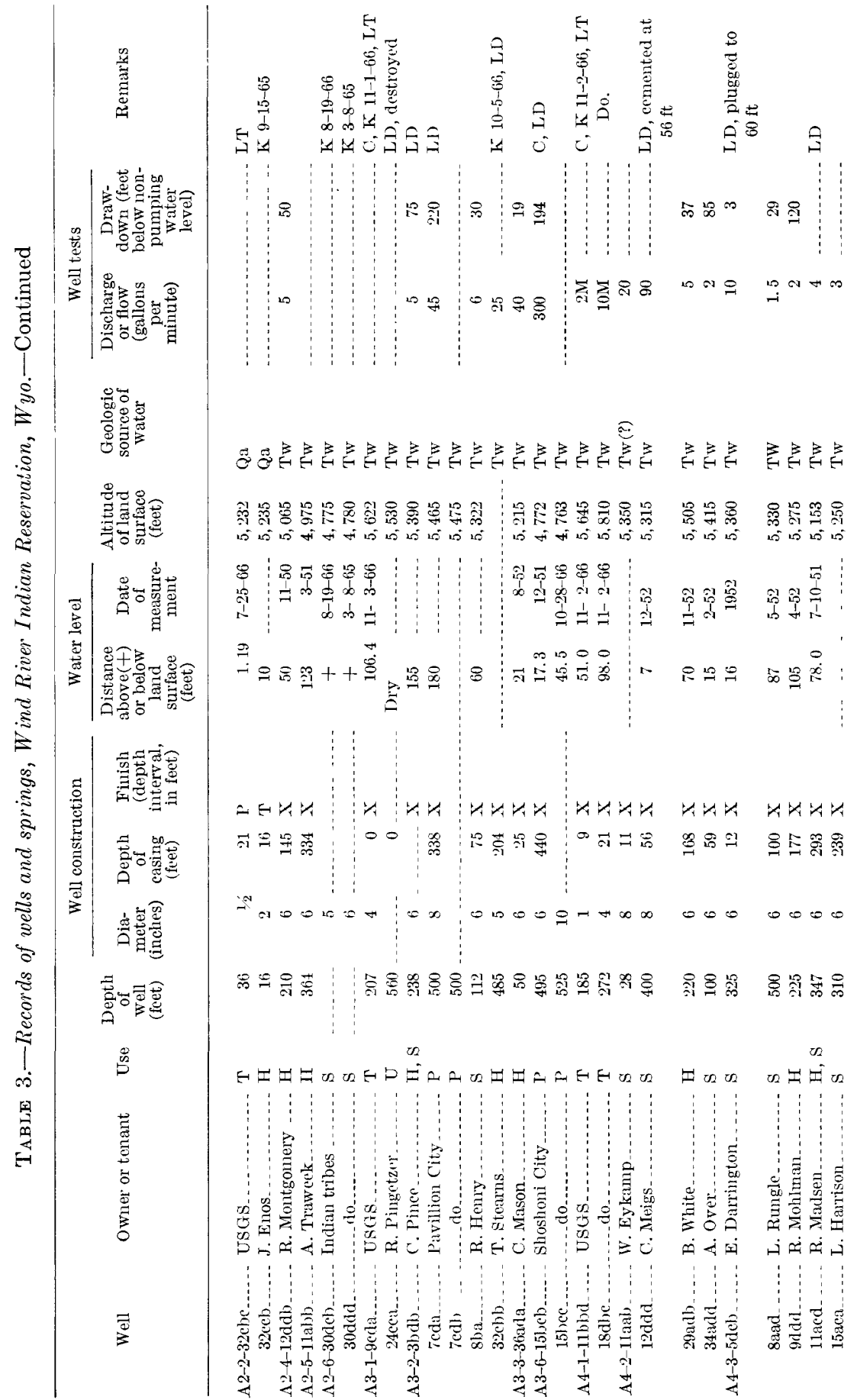




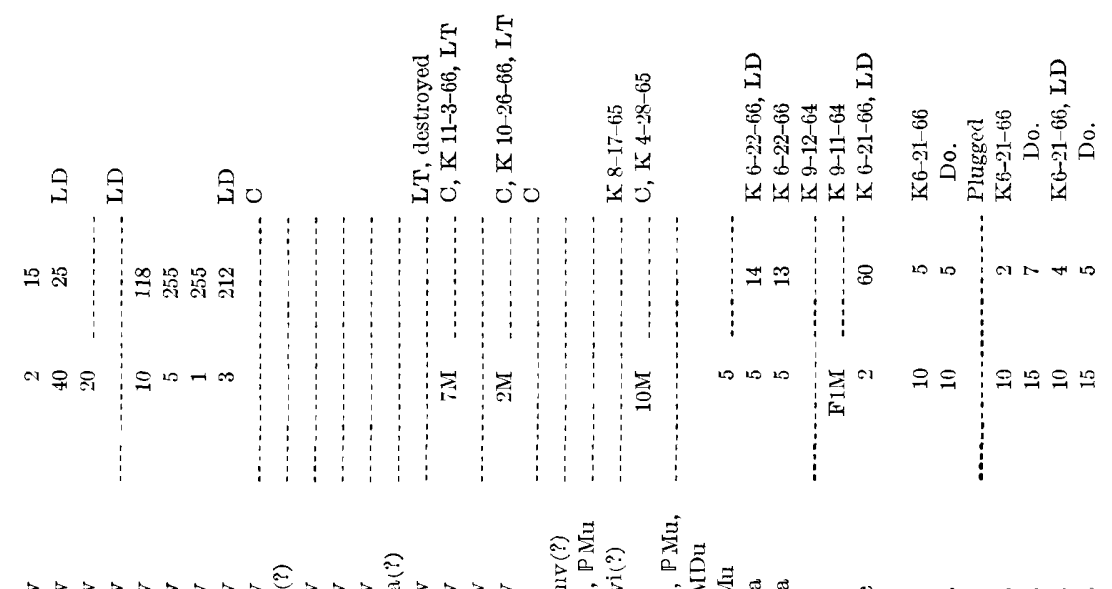

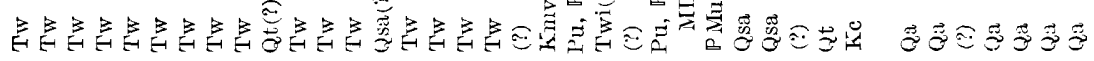

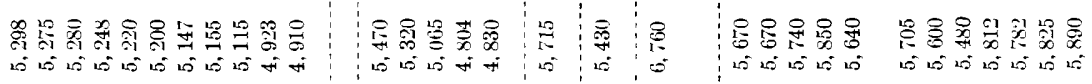

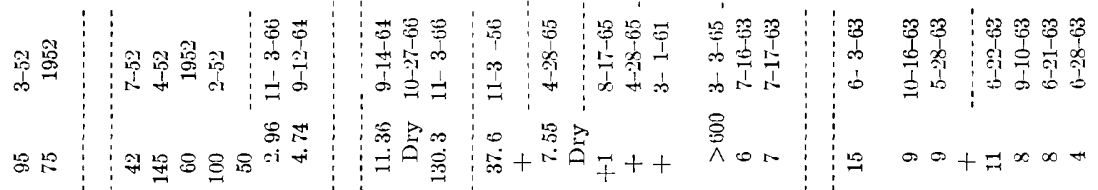

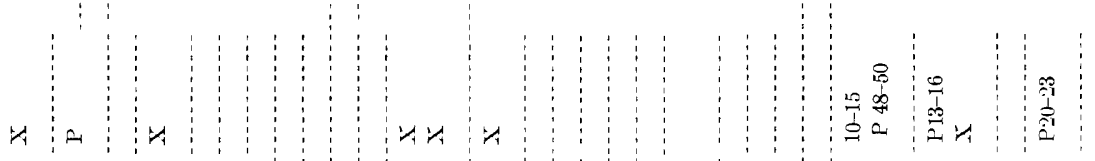

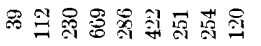

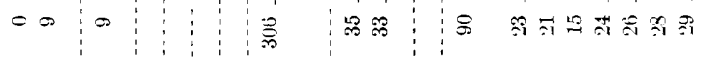

$00000000 \pi 0$

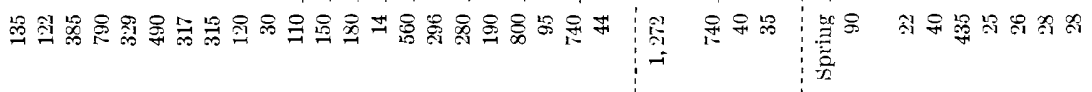
का का का ग2 02

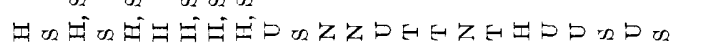

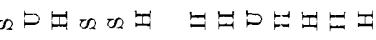

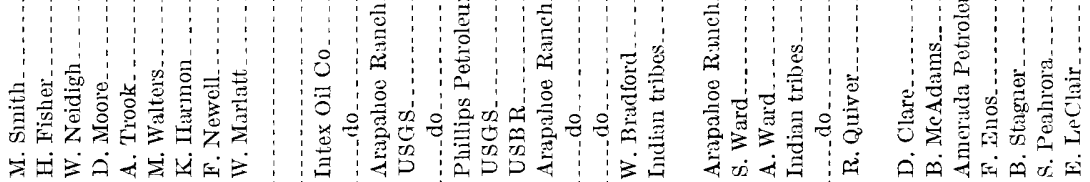

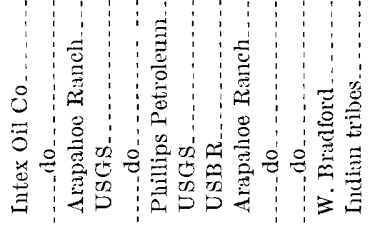

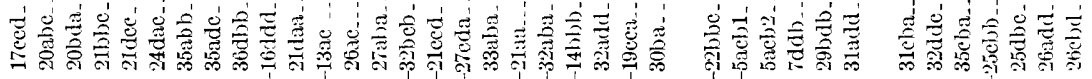

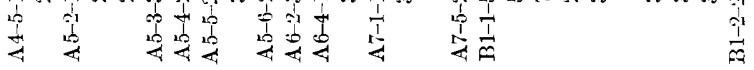
$318-228-69-6$ 
A

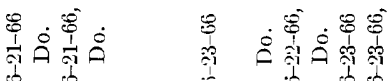

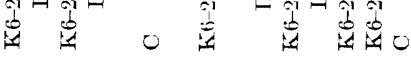

• $\infty$ ๓

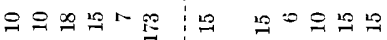

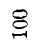

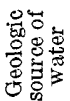

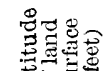

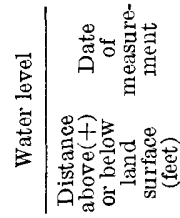

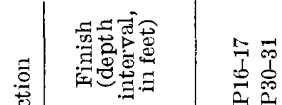

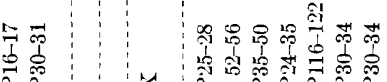

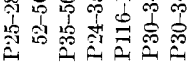

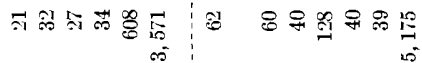

OXX从

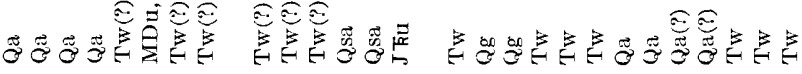

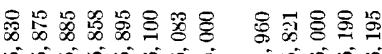

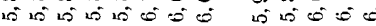

ॠ

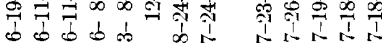

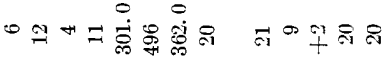

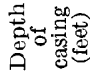

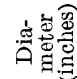

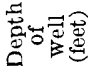

$\stackrel{\infty}{:}$

$0000 \pi 900$

000000

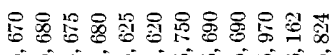

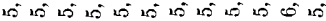

(स)

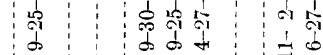

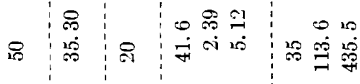

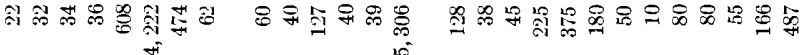

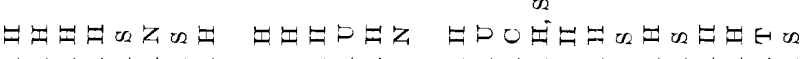

$\vec{\sharp}$
$\square$
$\vdots$
$\dot{0}$
$\overrightarrow{0}$

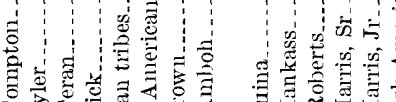

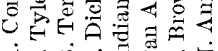

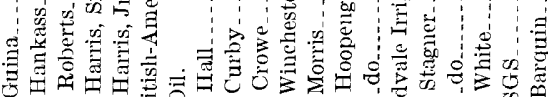

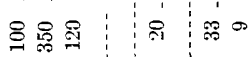

य的的白的允

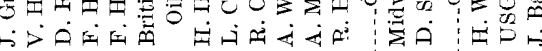

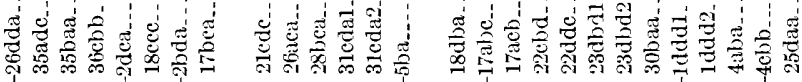
$\stackrel{\vec{F}}{2}$

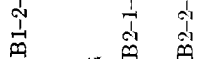

宛

政施

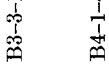




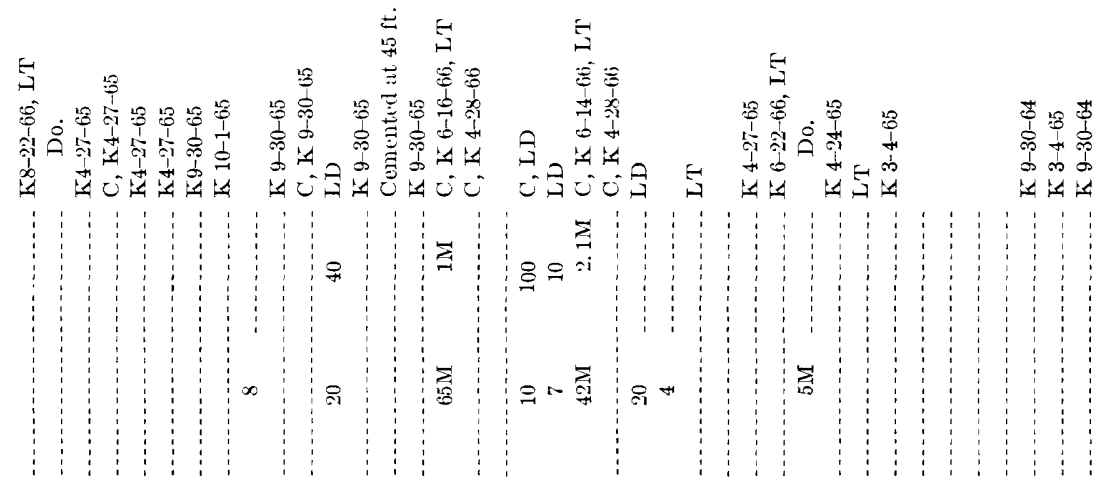

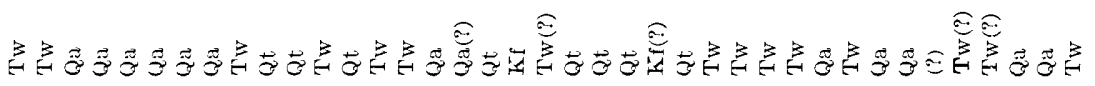

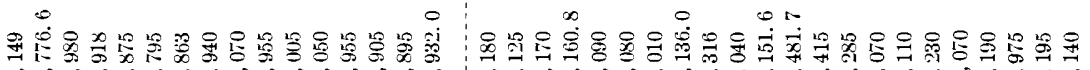

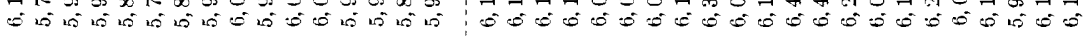

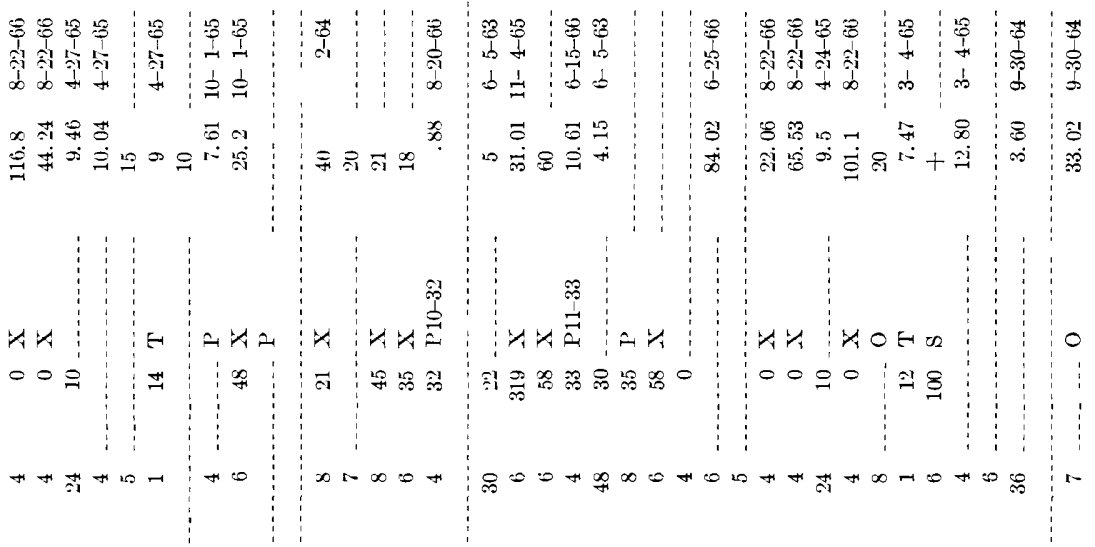

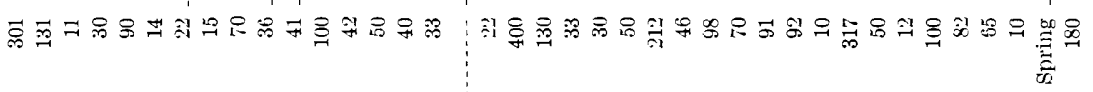

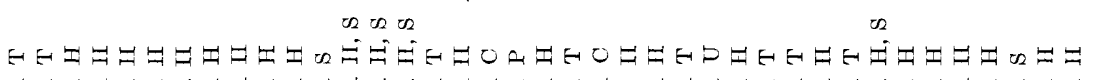

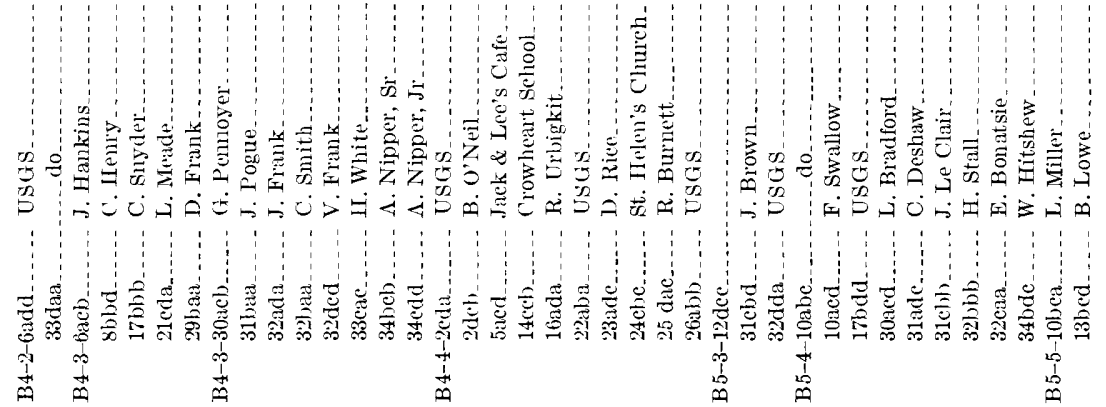




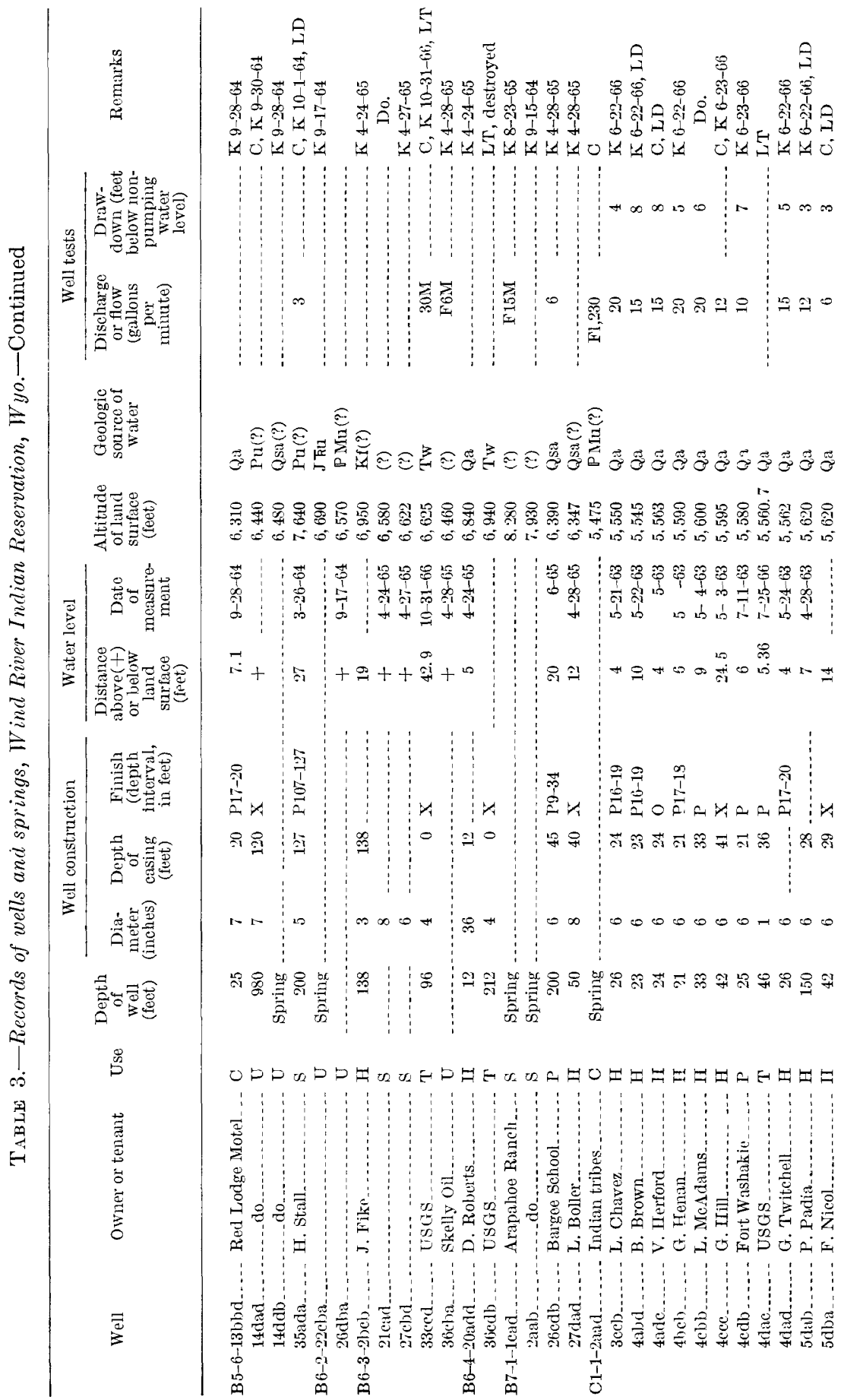




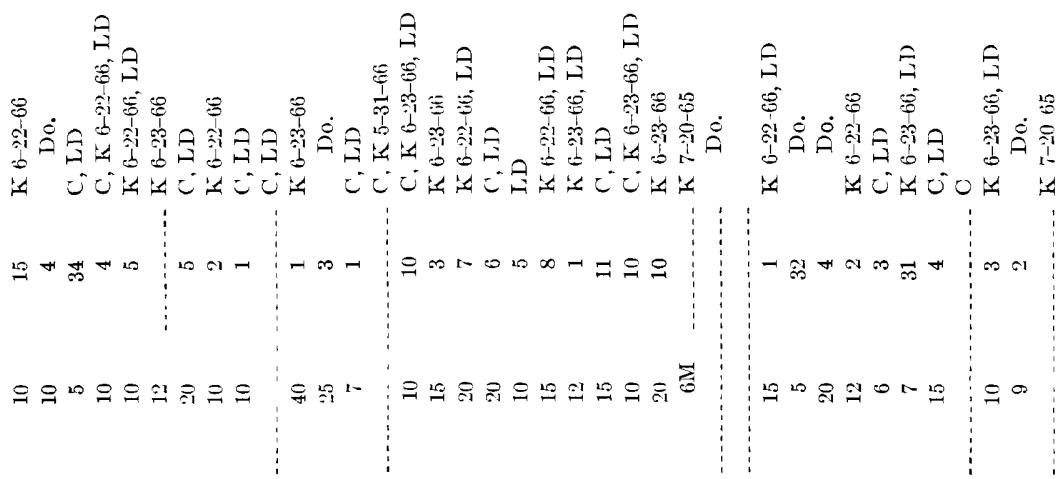

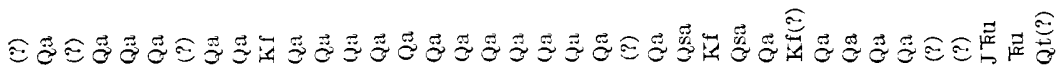

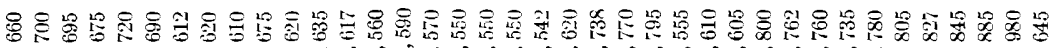

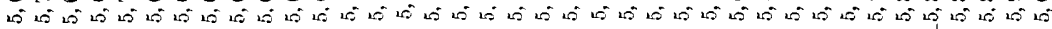

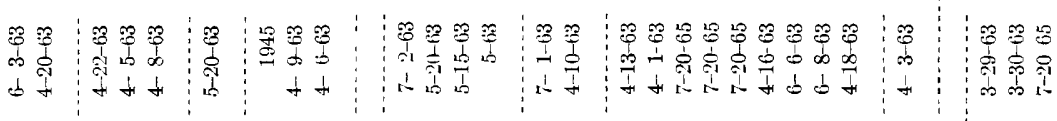

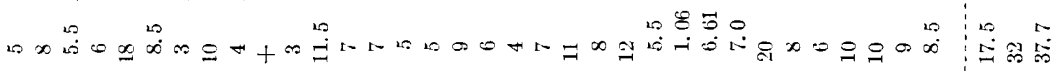

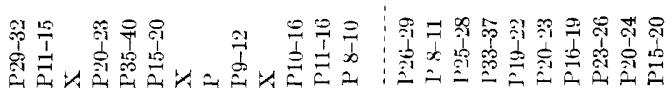

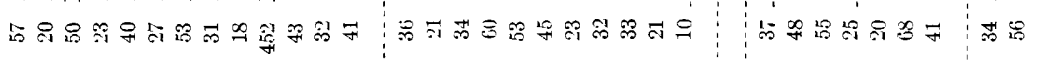

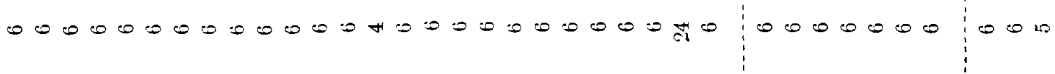

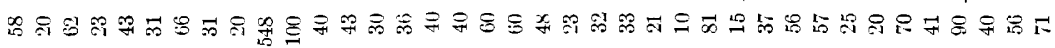

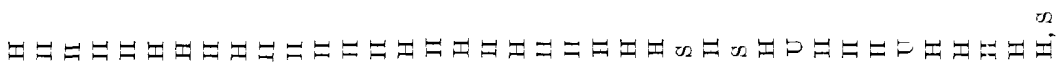

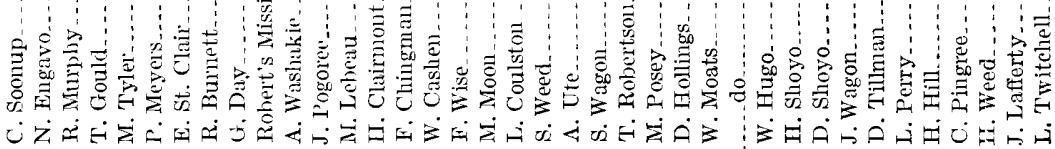

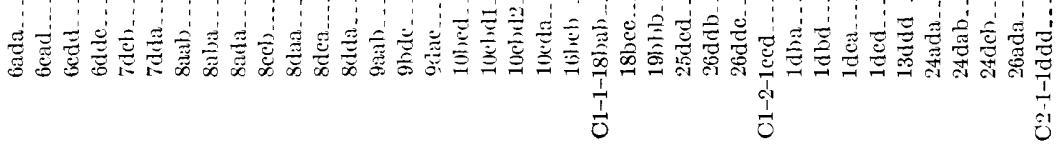




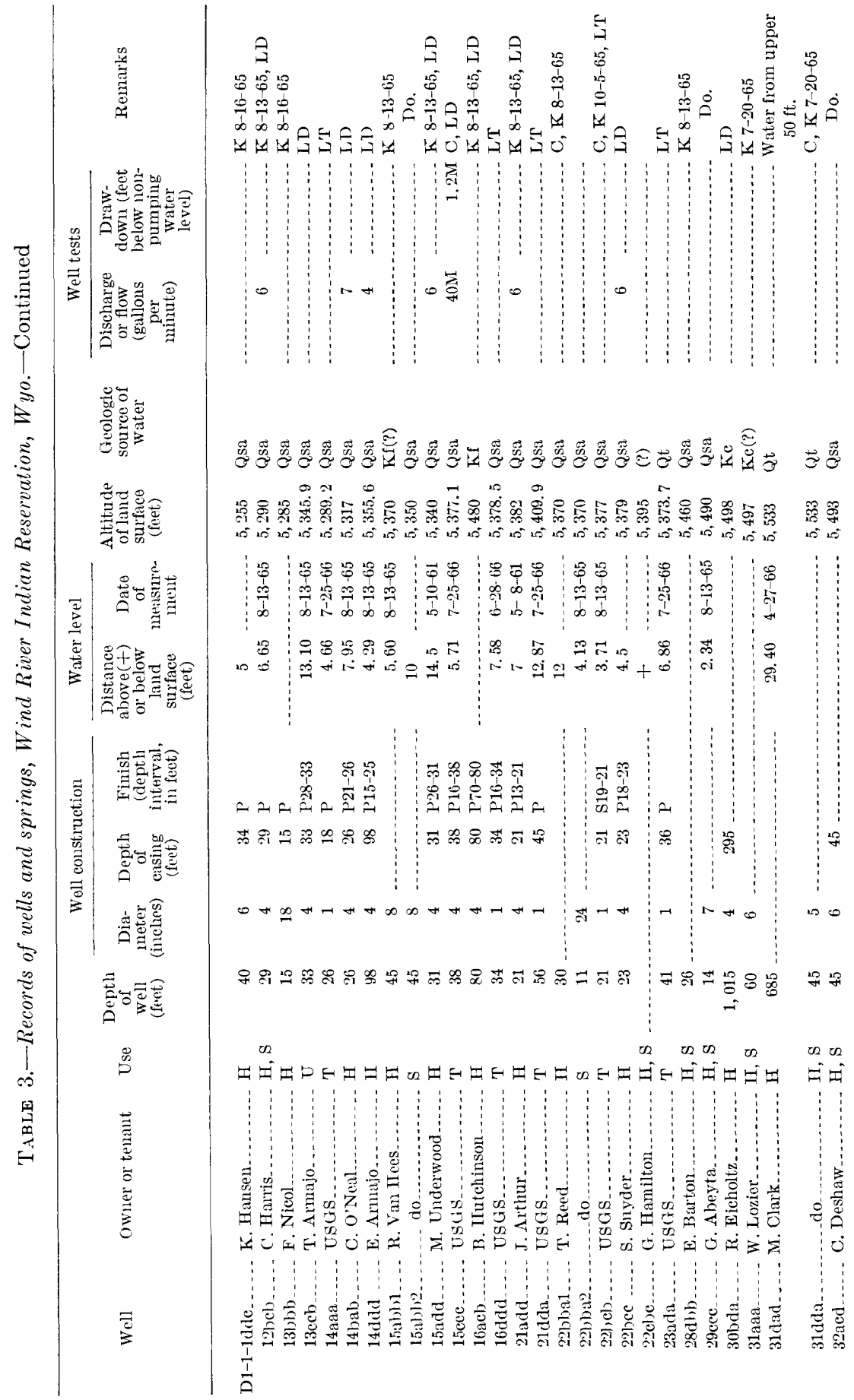




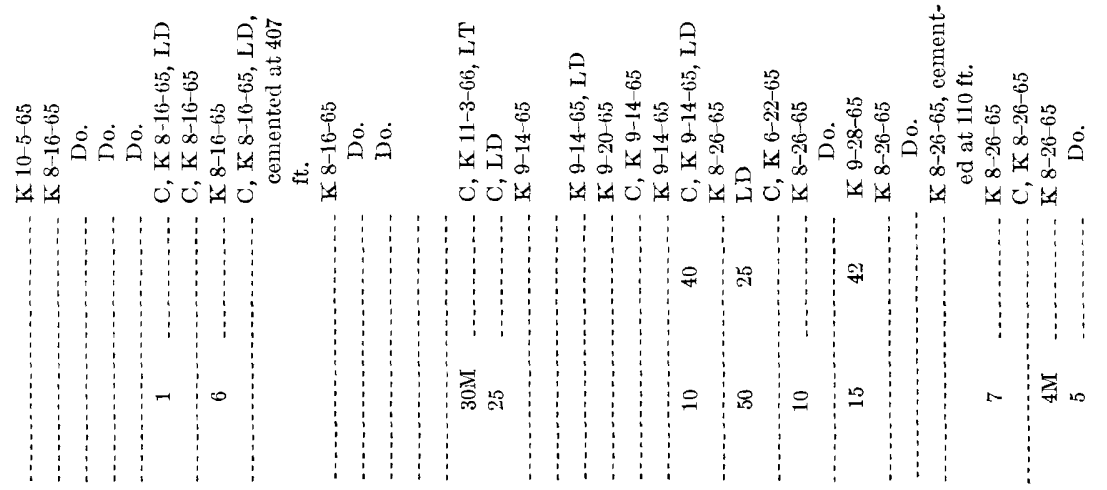

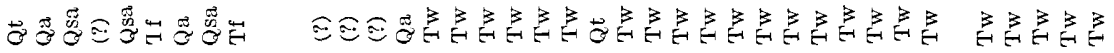

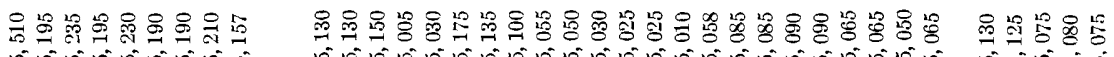

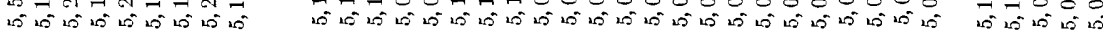

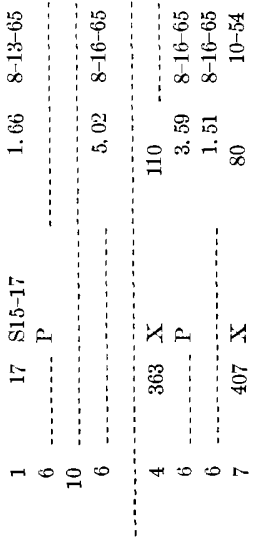

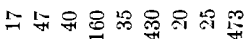

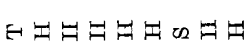

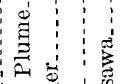

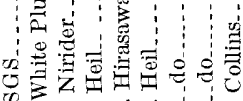

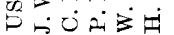

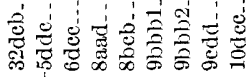
i

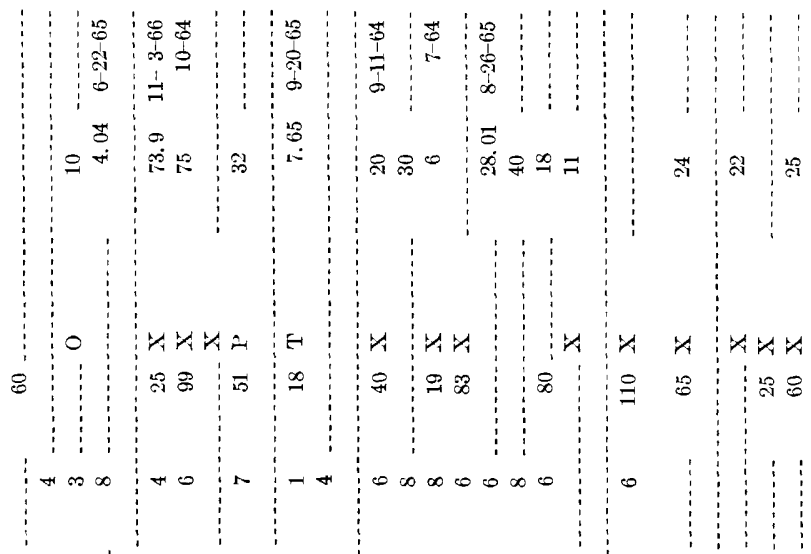

유ㅇㅛㅛ

or 20

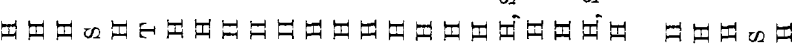

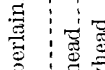

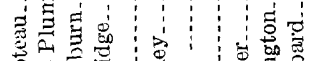

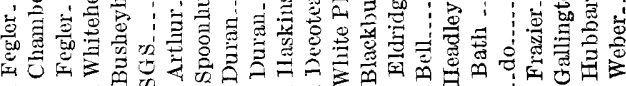

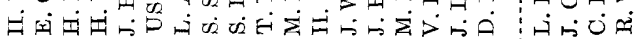

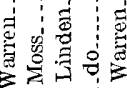
मिं $\dot{0}$ :

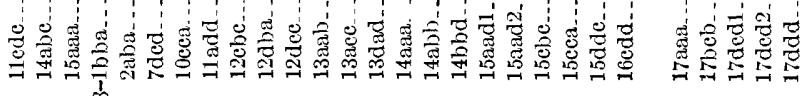




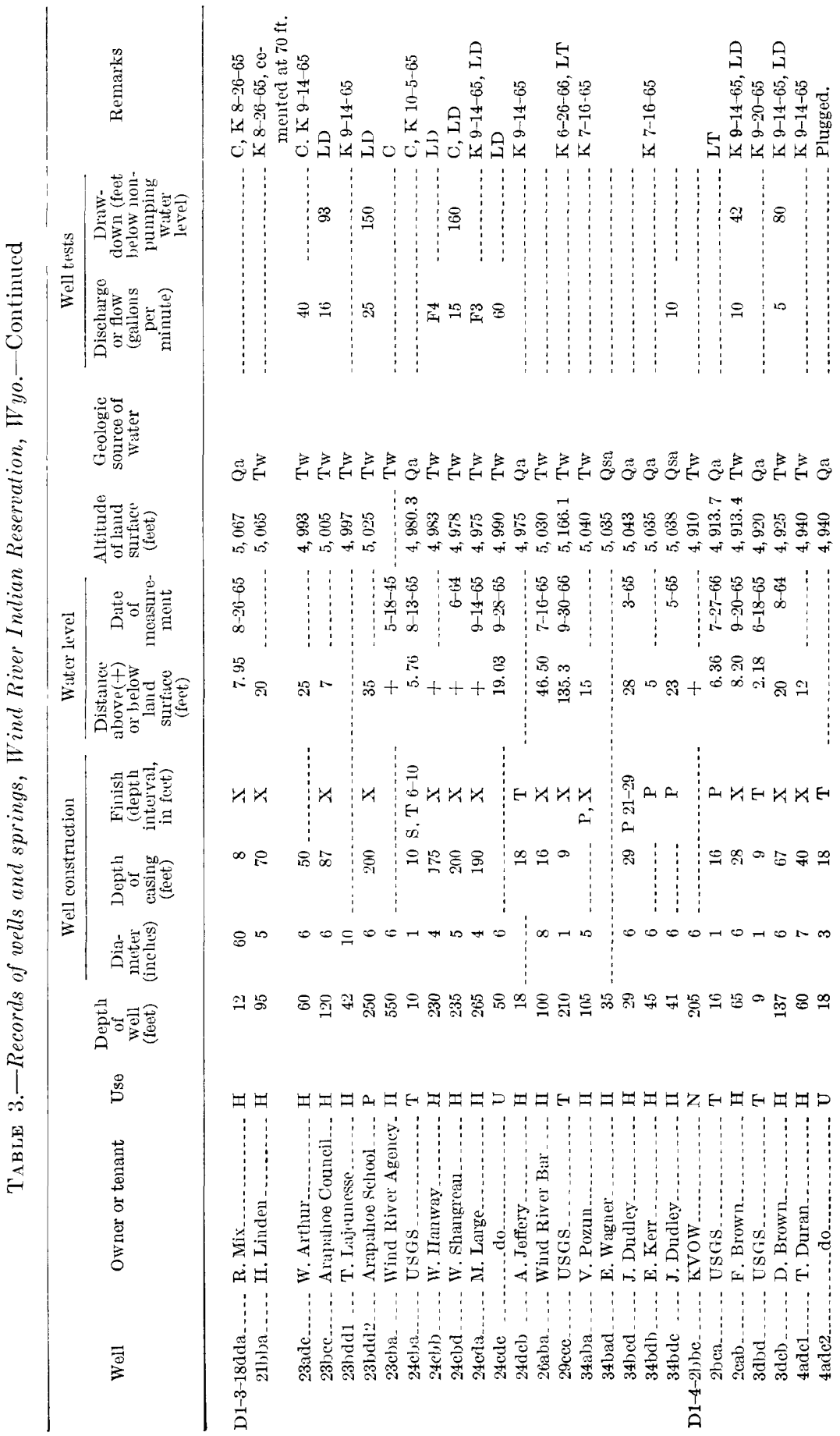




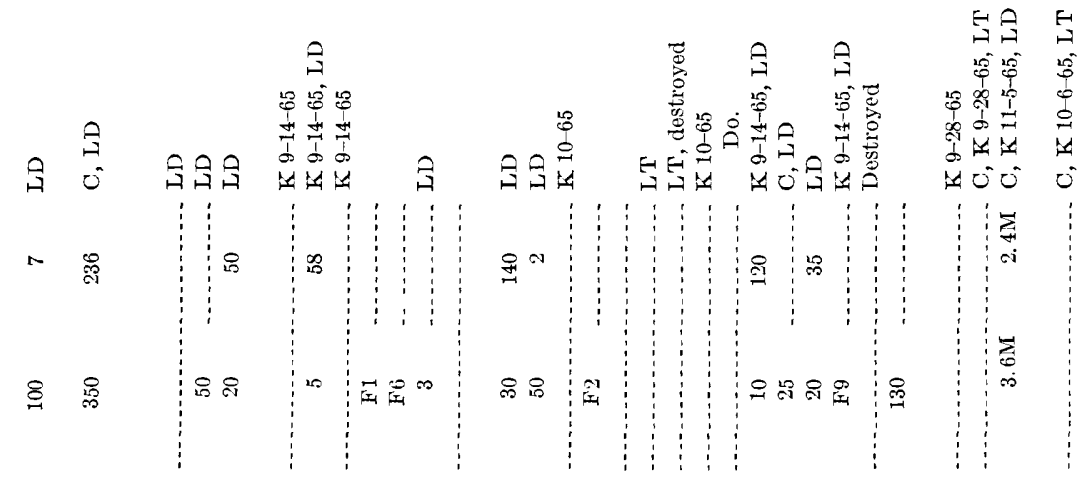

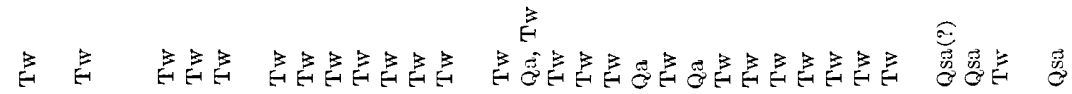

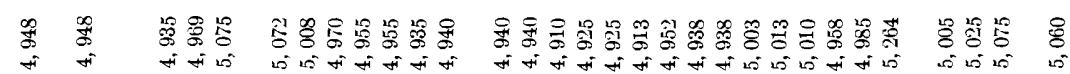

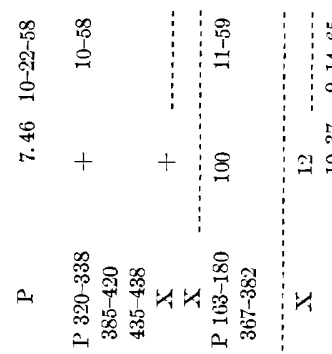

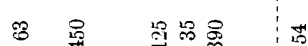

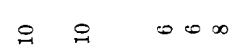

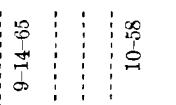

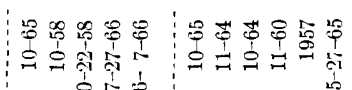

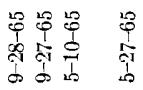

\begin{tabular}{r|r:r|r}
$n$ & 0 \\
$\infty$ & 0
\end{tabular}

范尽

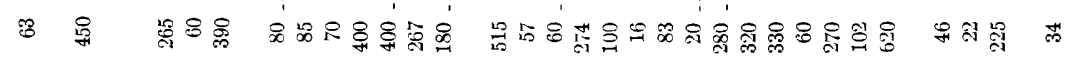

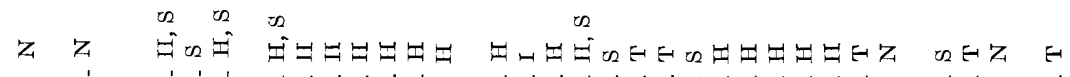

范范

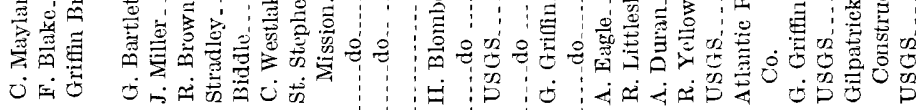

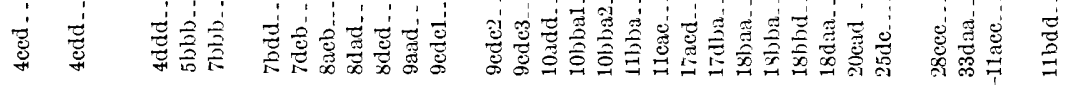




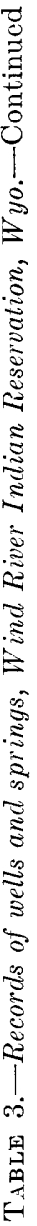

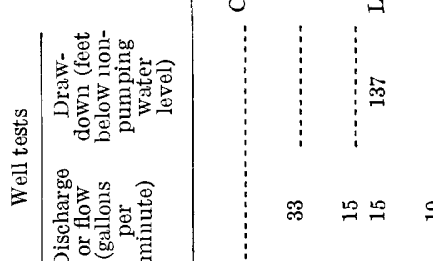

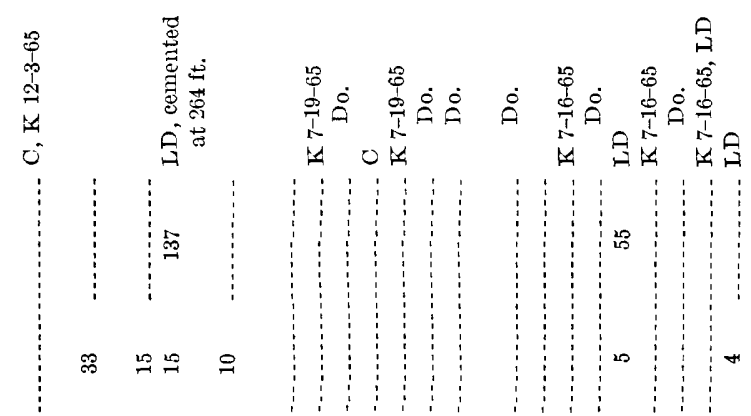

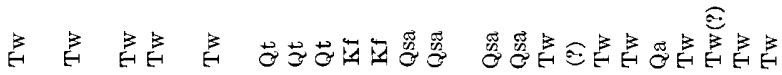

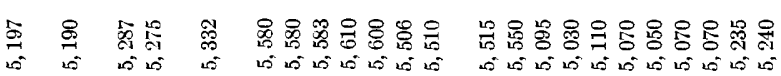

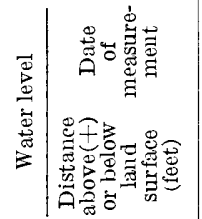

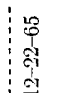

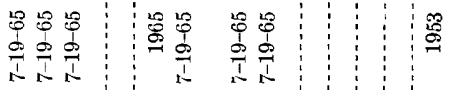
ㅇํำ

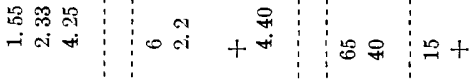

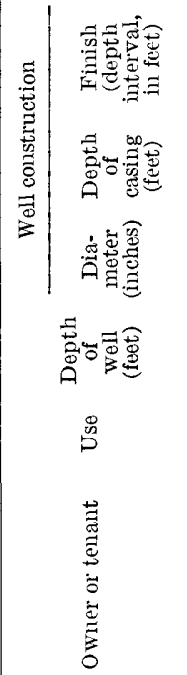

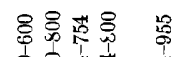

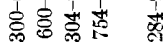

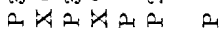

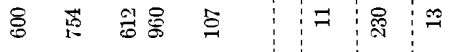

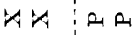
응여 N 1 -

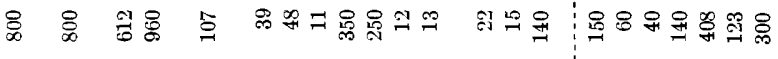
乙 乙 乙九 万 ○ 离

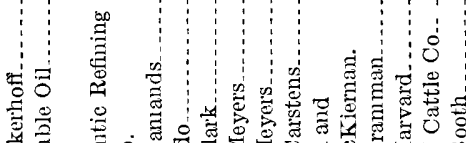

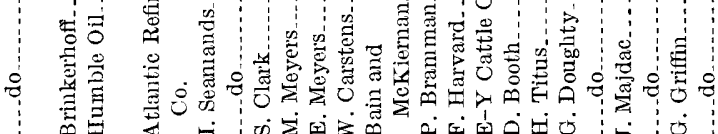
m

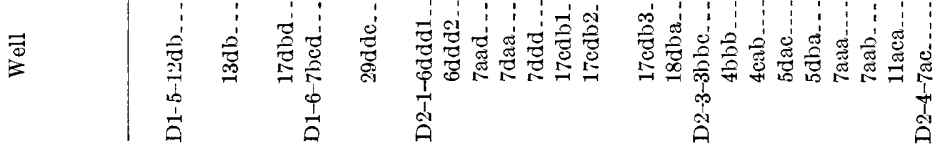


TABLE 4.-Dillers' logs of wells

[Yields in gallons per minute, and dissolved solids, in parts per million, are given in pareutheses where a vailable]

\begin{tabular}{|c|c|c|c|c|c|}
\hline Material & $\begin{array}{c}\text { Thick- } \\
\text { ness } \\
\text { (feet) }\end{array}$ & $\underset{\text { (feet) }}{\text { Depth }}$ & Material & $\begin{array}{c}\text { Thick- } \\
\text { ness } \\
\text { (feet) }\end{array}$ & $\begin{array}{c}\text { Depth } \\
\text { (feet) }\end{array}$ \\
\hline
\end{tabular}

\section{Well A1-1-27ddd}

Sand, gravel, and boulders . . . . $\quad 20$

Shale, dark, soft ........... 5

Shale, light-gray, sticky _....... 10

Shale, sandy, medium-dark
(11/2 $\mathrm{gpm}$ sulfur water at 40

ft) $\ldots \ldots$

Shale, sandy, dark............ 50

Sandstone, dark (water) ........ 44

\section{Well A1-1-33bbb}

Soil, heavy clay ............... Sand, gravel (alakali water) . . . . Shale, sandy, dark-gray ( $3 \mathrm{gpm}$ at $30 \mathrm{ft}, 6 \mathrm{gpm}$ at $60 \mathrm{ft}) \ldots \ldots$. Shale, black (gas) $\ldots . . . . . . . .$. Shale, sandy, gray ............. . Shale, dark, sticky . . .......... Shale, dark, hard ............. Bentonite and sandstone....... Shale, dark, hard.............
2

20

366

12

30

30

10

5

65
Mud, dark, soft (with bad odor) _ $\quad 3 \quad 543$ Sand. soft, black and white

(with sulfur water) ......... $\quad 7 \quad 550$

Sandstone, hard and soft layers. $\quad 50 \quad 600$

Limestone, hard (5 hr drilling) _ $\quad 2 \quad 602$

Sandstone, gray .............. $18 \quad 620$

Shell, hard _...

Bentonite .... ............... 11622

Rock, hard... ............... $\quad 2 \quad 624$

Shale, sandy, gray, hard....... $\quad 88 \quad 712$

\section{Well A1-1-35adc}

Surface...................... 2

Gravel and sand............... 16
Shale, dark-gray .............. 3

21

\section{Well A1-1-35ceb}

Silt, sandy

Gravel and sand...............

\section{0}

20

Mud, blue

2

32

$10 \quad 30$

\section{Well A1-3-11bcd}

Soil ............................... 3

Sandstone, soft . . .

Shale, sandy

Sandstone, hard ............ 3
Shale, hard, blue ............. $423 \quad 458$

Sandstone, hard ............ $10 \quad 468$

Sluale ...................... $287 \quad 755$

Water sand, coarse $\ldots \ldots \ldots$

\section{Well A1-3-34dac}

Topsoil, sandy . . . . . . . . . . . . 4

Gravel ........................ 18

Shale, gray _...

Shale, gray, sandy ........... 55

Sandrock, gray ...............
Shale, sandy, hard, blue _..... $\quad 10 \quad 100$

Shale, sandy, gray........... . $\quad 2 \quad 102$

Sand, gray .................. 507

Shale, sandy, hard, blue....... $\quad 8 \quad 115$ 
TABLE 4.-Drillers' logs of wells-Continued

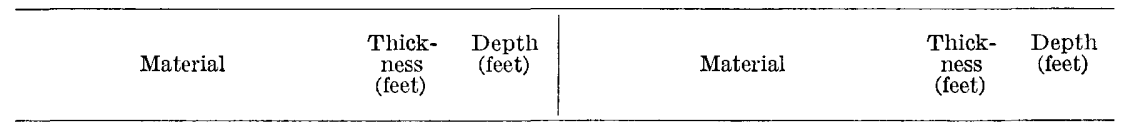

\section{Well A1-4-21ddd}

Topsoil, sandy

Sand and gravel

Shale, yellowish-gray ......... 12

Sandrock, yellow (hard water)_ $\quad 14$

Shale, sandy, gray ........... 16

Shale, sandy, blue........... 5

Shale, sandy, gray ............. 19

Shale, blue, hard.

19
9

Shale, sandy, gray............
Shale, sandy, blue............
Shale, sandy, gray............
Shale, sandy. blue............
Shale, sandy, gray

\section{Well A1-4-26caa}

Soil, sandy 3

Gravel........................... Shale, cavey, blue .. Shale, sandy, gray -......... . . Shale, sandy, blue........... . Shale, blue and brown ......... Shale, sandy, blue........... Shale, sandy, gray ............ Water sand ................ Shale, brown ..............

Shale, sandy, blue .......... Water sand.................... Shale, sandy, blue and brown Shale, sandy, gray ........... Water sand ........................ Shale, sandy, blue..... . . .... Water sand ....................... Shale, sandy, blue............ Water sand ................ Shale, brown and blue.......... Shale, sandy, gray, very hard... Shale, cavey, brown, yellow, gray.

Shale, blue, sandy............. Shale, gray, and hard shells....-

\begin{tabular}{|c|c|c|}
\hline $\begin{array}{l}\text { Shale, brown and blue, hard } \\
\text { and sticky }\end{array}$ & 69 & 424 \\
\hline Hard-rock layer & 3 & 427 \\
\hline Water sand $\ldots$ & 10 & 437 \\
\hline $\begin{array}{l}\text { Shale, hard, blue and dark- } \\
\text { gray }\end{array}$ & 18 & 455 \\
\hline Shale, hard, dark-gray & 23 & 478 \\
\hline Water sand & 12 & 490 \\
\hline Shale, dark-brown, sticky $\ldots \ldots$ & 20 & 510 \\
\hline Water sand & 15 & 525 \\
\hline Shale, blue and brown & 15 & 540 \\
\hline Shale, red-brown & 15 & 555 \\
\hline 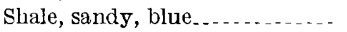 & 12 & 567 \\
\hline Shale, red-brown & 13 & 580 \\
\hline Shale, sandy, gray & 10 & 590 \\
\hline Water sand & 7 & 597 \\
\hline Shale, sandy, gray, hard........ & 9 & 606 \\
\hline Sand .................... & 1 & 607 \\
\hline Shale, sandy, hard, gray $\ldots \ldots$ & 12 & 619 \\
\hline Shale, brown & 15 & 634 \\
\hline Shale, sandy, blue $\ldots$ & 10 & 644 \\
\hline Water sand & 12 & 656 \\
\hline Shale, sandy, hard, blue $\ldots \ldots$ & 14 & 670 \\
\hline Sliale, sandy, hard, gray ........ & 10 & 680 \\
\hline Shale, dark-gray & 5 & 685 \\
\hline Shale, brown $\ldots . . . . . . . .$. & 15 & 700 \\
\hline
\end{tabular}

\section{Well A1-4-27aca}

Soil, sandy (surface water) Gravel (hard water) ............ Sandstone, light-brown and yellow

Sandstone, blue and gray ....... Shale, gray ................

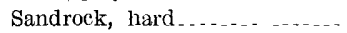
Shale, gray _.............. Sandstone, hard ............. Shale, sandy, hard, gray _... ... Shale, gray, sticky - . . . . . . . . - Shale, sandy, hard, gray ........
18

18

Shale, gray, and hard shells of rock Shale, gray, sticky, hard _..... 505 Shale, sandy, hard, gray ........ $\quad 6 \quad 6 \quad 121$ Shale, blue and gray, sticky,

soft Shale, gray, with blue streaks . $\quad 50 \quad 175$ Shale, sandy, gray ............... $\quad 10 \quad 185$ Shale, blue, sticky ............. 50 Shale, hard, gray Sand (water) ............... 4212 Shale, sandy, blue, hard...... 315 
TABLE 4.-Drillers' logs of wells-Continued

\begin{tabular}{|c|c|c|c|c|c|}
\hline Material & $\begin{array}{c}\text { Thick- } \\
\text { ness } \\
\text { (feet) }\end{array}$ & $\begin{array}{l}\text { Depth } \\
\text { (feet) }\end{array}$ & Material & $\begin{array}{c}\text { Thick- } \\
\text { ness } \\
\text { (feet) }\end{array}$ & $\underset{\text { (feet) }}{\text { Depth }}$ \\
\hline \multicolumn{6}{|c|}{ Well A1-4-27aca-Continued } \\
\hline Sand (water) & 7 & 222 & Shale, sticky, brown $\ldots . . . . .$. & 11 & 460 \\
\hline Shale, gray, sticky & 3 & 225 & Shale, sandy, gray & 5 & 465 \\
\hline Shale, brown & 5 & 230 & Shale, brown, and hard shells . & 47 & 512 \\
\hline Shale, gra y & 12 & 242 & Shale, brown and blue . . ....... & 13 & 525 \\
\hline Shale, blue $\ldots . . . . . . .$. & 8 & 250 & Shale, sandy, gray, hard........ & 10 & 535 \\
\hline Shale, brown & 10 & 260 & Shale, sticky, brown and blue.. & 7 & 542 \\
\hline Shale, gray & 5 & 265 & Shale, sandy, gray, hard...... & 3 & 545 \\
\hline Water sand and hard shells..... & 20 & 285 & Sand (water) & 5 & 550 \\
\hline Shale, gray, hard & 15 & 300 & Shale, gray, hard & 5 & 555 \\
\hline Sand (water) $\ldots \ldots$ & 5 & 305 & Shale, sticky, brown and blue. - & 5 & 560 \\
\hline Shale, sandy, hard, gray........ & 9 & 314 & Shale, gray, hard $\ldots \ldots \ldots$ & 5 & 565 \\
\hline Shale, blue, hard & 2 & 316 & Shale, sticky, light-brown . ..... & 25 & 590 \\
\hline Shale, gray, and hard shells.... & 19 & 335 & Shale, gray, hard & 10 & 600 \\
\hline Shale, brown and blue........ & 5 & 340 & Shale, sticks, blue and brown & 18 & 618 \\
\hline Shale, sandy, light-brown_...... & 10 & 350 & Sand (water) & 22 & 640 \\
\hline Sand and hard shells ............ & 15 & 365 & Shale, brown & 10 & 650 \\
\hline Shale, gray and blue, hard..... & 30 & 395 & Sandstone, brown & 5 & 655 \\
\hline Shale, brown and blue, sticky & & & Sandstone, gray, hard & 5 & 660 \\
\hline and hard $\ldots$ & 5 & 400 & Shale, hrown and blue.......... & 20 & 680 \\
\hline Shale, medium-gray ............ & 15 & 415 & Sand (water) & 45 & 725 \\
\hline Shale, blue and brown . ........ & 25 & 440 & Shale, yellow & 5 & 730 \\
\hline Shale, sandy, hard, gray ....... & 9 & 449 & & & \\
\hline
\end{tabular}

\section{Well A1-4-29dcb}

Soil, sandy, and gravel........ 10

Sand, fine...................

Gravel ......................

Sand and gravel..............

Sand, fine........................

Sand and gravel..............

Shale and sand

Sand, fine ........................

Gravel........................

Shale, variegated yellow and

blue

Shale, sandy, blue.............

Shale, sandy, gray ..............

Shale, blue and green...........

Shale, blue, red, brown.........

Shale, sandy, blue $\ldots . . . . . . . . .$.

Shale, sandy, gray, hard........

Shale, soft, gray ..............

Shale, gray, hard..............

Sandstone, gray, soft ...........

Sandrock, gray, hard..........

Shale, gray, hard

Shale, sandy, gray, medium-

hard.......................

Sandrock, gray, soft............

Shale, sandy, gray, medium-

soft............................

Shale, sandy, blue and gray,

sticky -
Shale, very sandy, gray, hard. .

Shale, sandy, blue, hard........

Shale, gray, sandy, hard........

Shale, gray; some gray sand-

rock ..................... 8

Sandrock, gray; trace of shale;

red and black specks......... $53 \quad 346$

Shale, sandy, gray, hard,

sticky ................... $64 \quad 410$

Shale, blue, sticky .............. $\quad 3 \quad 413$

Shale, dark-gray, sticky ......... $\quad 7 \quad 420$

Shale, sandy, blue, sticky ...... $\quad 1 \quad 421$

Shale, sandy, gray, sticky ...... $\quad 9 \quad 430$

Shale, blue; some purple and

brown

Sand, white, sharp (water, 445

ppm)

Shale, brown; some yellow and

gray; hard, sticky ........... $\quad 40 \quad 500$

Sand shell, hard.............. 44504

Shale, brown and blue.......... $41 \quad 41$

Sand, grayish-white (water) _... $\quad 15 \quad 560$

Shale, gray .................... 55

Sand, fine, white and flecked

(water)

Shale, blue................... $\quad 6 \quad 591$

Sand, white and flecked (water) _ $\quad 17 \quad 608$

Shale, brown and light-blue.... $\quad 22 \quad 630$

250

Sand, flecked (water) ........... 10

640 
TABLE 4,-Drillers' logs of wells-Continued

\begin{tabular}{ccc|ccc}
\hline Thick- & $\begin{array}{c}\text { Depth } \\
\text { (feet) }\end{array}$ & Material & Material & $\begin{array}{c}\text { Thick- } \\
\text { ness } \\
\text { (feet) }\end{array}$ & $\begin{array}{c}\text { Depth } \\
\text { (feet) }\end{array}$ \\
\hline
\end{tabular}

\section{Well A1-4-29dcb-Continued}

Shale, blue-gray, hard

sand, white and flecked (water)

Shale, blue and brown, sticky -.

Sand (water, gas bubbles) . .....

Shale, blue and brown.........

Sand (water)

Shale, blue

Sand (water) .....................

Sand shells, hard.............

Sand (water)

Hard rock and sand (drilled 1

ft per hr) ... . . . . . . . . . . . . .

shale, blue and brown, hard,

sticky ...................

Sand shells, gray, hard.......

Shale, light-brown, sticky - ..... .

Shale, light-gray (gas, oily

rancid odor)

$\begin{array}{rl}12 & 652 \\ 3 & 655 \\ 15 & 670 \\ 4 & 674 \\ 11 & 685 \\ 10 & 695 \\ 3 & 698 \\ 6 & 704 \\ 19 & 723 \\ 10 & 733 \\ 5 & 738 \\ 17 & 755 \\ 21 & 776 \\ 24 & 800 \\ 18 & 818\end{array}$

Shale, dark-hrown, hard

(drilled $1 \mathrm{ft}$ per lir) . . .

Sand shells, hard_............ $\quad 18 \quad 843$

Shale, brown, sticky, hard,

some blue shale.......... $\quad 10 \quad 853$

Sand shells, hard............. $17 \quad 17 \quad 870$

Shale, brown; some blue (gas,

oily)

Shale, sandy, dark-gray

(drilled $2 \mathrm{ft}$ per hr) $\ldots \ldots \ldots$..... $11 \quad 898$

Shale, dark-gray, sticky _....... $\quad 17 \quad 915$

Shale, gray, hard............. $13 \quad 928$

Sandstone, very soft_........ $12 \quad 940$

Sand shells, hard _............. $\quad 20 \quad 960$

Sandstone, soft ............. 44964

Shale, gray, hard ........... $6 \quad 6 \quad 970$

Sandstone $\ldots \ldots \ldots \ldots 2$

Shale, brown and blue....... $12 \quad 994$

\section{Well A1-4-31ad}

\begin{tabular}{|c|c|c|c|c|c|}
\hline . & 30 & 30 & Sandstone $\ldots . . .$. & 10 & 250 \\
\hline Shale_.. & 170 & 200 & 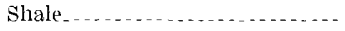 & 105 & 355 \\
\hline Shale and sandstone.... ....... & 10 & 210 & Sandstone (water) $\ldots . . . . . . . .$. & 30 & 385 \\
\hline Shale_. & 30 & 240 & Shale, red, brown, green........ & 15 & 400 \\
\hline
\end{tabular}

\section{Well A1-1-33aab}

Soil

Sand and gravel..............

Sandstone, yellow. .............

shale, yellow, gray, green.......

Sandstone, gray and red.......

Shale, blue and gray ............

Sandstone, gray, black, red.....

Shale.........................

Sandstone, coarse, hard.........

Shale, gray

$\begin{array}{rr}7 & 7 \\ 10 & 17 \\ 27 & 44 \\ 21 & 65 \\ 21 & 86 \\ 87 & 173 \\ 30 & 203 \\ 5 & 208 \\ 7 & 215 \\ 5 & 220\end{array}$

Sandstone, coarse, liard........ $\quad 13 \quad 233$

Shale, gray ................. $42 \quad 275$

Sandstone, red and white

(coarse 295-300) ............ $35 \quad 310$

Shale, gray, brown, and blue... $\quad 56 \quad 366$

Sandstone, hard.............. $\quad 19 \quad 385$

Shale, blue, gray, brown....... $\quad 85 \quad 470$

Saudstone and hard shells....... $\quad 28 \quad 498$

Shale, sandy, gray............ $2 \quad 500$

\section{Well A1-4-3tac}

Topsoil, sandy

Gravel........................ 4

Shale, yellow-blue............. 19

Sandstone, yellow . . . . . . . . . 26

Shale, sandy, blue (seep of

water at $60 \mathrm{ft}, 2,240 \mathrm{ppm}$ ) .....

shale, sandy, gray .............

Shale, sandy, blue.
Shale, sandy, gray............ $\quad 29$

Water sand (15 gpm, 3,540

ppm)

Shale, blue ................. 112

Shale, sandy, gray

Shale, blue.................. 3

Slrale, sandy, dark-gray . . . . . . . .

Shale, sticky, blue..
112

126

138

149

152

158 164 
T.1BLE 4.-Driller's' logs of wells-Continued

\begin{tabular}{|c|c|c|c|c|c|}
\hline Material & $\begin{array}{l}\text { Thick- } \\
\text { ness } \\
\text { (feet) }\end{array}$ & $\underset{\text { (feet) }}{\text { Depth }}$ & Material & $\begin{array}{c}\text { Thick- } \\
\text { ness } \\
\text { (feet) }\end{array}$ & $\begin{array}{l}\text { Depth } \\
\text { (feet) }\end{array}$ \\
\hline \multicolumn{6}{|c|}{ Well A1-4-34ac-Continued } \\
\hline Shale, brown; with coal streak.. & 6 & 170 & Shale, sandy, light-blue.......... & 13 & 365 \\
\hline Shale, blue. & 11 & 181 & Shale, sandy, gray ............ & 5 & 370 \\
\hline Shale, sandy, gray & 97 & 278 & Sandstone, very coarse $\ldots . . .$. & 25 & 395 \\
\hline Shale, sandy, light-blue. ...... & 9 & 287 & Water sand, coarse (10 gpm, & & \\
\hline Shale, gray, and hard shells..... & 43 & 330 & $910 \mathrm{ppm})$ & 8 & 403 \\
\hline Shale, sandy, gray ......... & 22 & 352 & Shale, sandy, hard, blue ....... & 3 & 406 \\
\hline
\end{tabular}

\section{Well A2-2-4ddd}

Shale, sandy, blue and yellowbrown.............................. Shale, sandy, blue; mixed with light-green shale (water at $18-30 \mathrm{ft}$.

Shale, saıdy, gray, hard....... Shale, sandy, blue............. Shale, sandy; gray with red specks.

Shale, sandy, gray, sticky _.....

Shale, sandy; gray with red

specks......................

Shale, sandy, sticky, gray......

Shale, sandy; gray with red

sand

Shale, sticky, blue............. .

Shale, sandy, gray, hard........

Shale, sticky, blue..............

Shale, sandy, gray ..............
Shale, sticky, blue

Shale, sticky, gray

Shale, sticky, blue; mixed with

$\begin{array}{rrr}\text { brown shale } & 9 & 275 \\ \text { Sandstone, bluish-red.......... } & 25 & 300\end{array}$

\begin{tabular}{l|lrr}
40 & Sandstone, bluish-red.......... & 25 & 300 \\
88 & Shale, sandy, gray .............. & 18 & 318
\end{tabular}

\begin{tabular}{r|rrr}
88 & Shale, sandy, gray ............. & 18 & 318 \\
100 & Shale, sandy, blue............ & 8 & 326
\end{tabular}

$12 \quad 100 \quad \begin{aligned} & \text { Shale, sandy, blue.......... } \\ & \text { Shale, sandy; gray with red }\end{aligned}$

30

10

130

140 Shecks.....................

Shale, sandy, dark-gray ........

Shale, sticky, hard, blue........

176

200

Sandrock, hard, gray..........

Shale, sandy, gray .............

shale, hrown and blue, hard. . -

Water sand, white (12 gpm).....

Shale, sticky, blue; mixed with

brown shale . ..............

Water sand, white............

shale, sandy, blue............
65

70

03

406

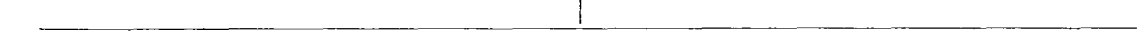

Well A2-2-16cdb

\begin{tabular}{|c|c|c|c|c|c|}
\hline Soil. & 2 & 2 & Sandstone, reddish-brown & & \\
\hline Sandstone. & 28 & 30 & (water, 4 gpnl) $\ldots \ldots . . . .$. & 33 & 75 \\
\hline Shale, light-gray and yellow.... & 12 & 42 & Shale, sandy, gray & 5 & 80 \\
\hline
\end{tabular}

\section{Well A2-2-18ada2}

Soil

Sardstone, yellow and blue

Shale, sandy, gray...........

Sandstone, gray (little water) - -

Shale, gray and blue . .........
Sandstone, gray - . .

shale, blue . ................. $31 \quad 412$

Sandstone, white (water) ....... $18 \quad 430$

Shale...................... 5435 
TABLE 4.-Drillers' logs of wells - Continued

\begin{tabular}{|c|c|c|c|c|c|}
\hline Material & $\begin{array}{l}\text { Thick- } \\
\text { ness } \\
\text { (feet) }\end{array}$ & $\begin{array}{l}\text { Depth } \\
\text { (feet) }\end{array}$ & Material & $\begin{array}{c}\text { Thick- } \\
\text { ness } \\
\text { (feet) }\end{array}$ & $\begin{array}{l}\text { Depth } \\
\text { (feet) }\end{array}$ \\
\hline \multicolumn{6}{|c|}{ Well A2-2-3ladd1 } \\
\hline Sand, gravel (hard water) ....... & 25 & 25 & Shale, blue & 5 & 135 \\
\hline Shale, blue............... & 10 & 35 & Sand with blue shale, very & & \\
\hline Sandstone, soft, blue (hard & & & streaked (water) & 25 & 160 \\
\hline water) & 15 & 50 & Shale, blue .......... & 3 & 163 \\
\hline 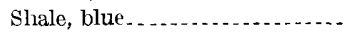 & 17 & 67 & Sand (hard water) & 12 & 175 \\
\hline Sand (hard water) & 6 & 73 & Shale, blue and gray $\ldots \ldots \ldots$ & 22 & 197 \\
\hline Shale, blue $\ldots \ldots$ & 9 & 82 & Sand and blue shale............. & 4 & 201 \\
\hline Shale, brown...................... & 8 & 90 & Shale, blue. & 11 & 212 \\
\hline Shale, gray and blue........ & 14 & 104 & Sandstone, coarse $\ldots \ldots \ldots$ & 4 & 216 \\
\hline Sand, white (hard water)....... & 21 & 125 & Shale, brown; sandy blue shale_ & 9 & 225 \\
\hline 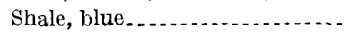 & 3 & 128 & Water sand (385 ppm) $\ldots \ldots \ldots$ & 5 & 230 \\
\hline Shale, brown & 2 & 130 & & & \\
\hline
\end{tabular}

\section{Well A3-1-24cca}

No $\log . \ldots . .105$

Shale, blue and gray . . ..........

Sandstone, gray ...............

Shale, sandy, gray ..............

Sandstone, gray .................

Shale, blue and gray . . .........

\begin{tabular}{rr|lrl}
105 & 105 & Sandstone.................. & 25 & 381 \\
69 & 174 & Shale, blue and gray $\ldots \ldots \ldots \ldots .$. & 108 & 489 \\
51 & 225 & Sandstone, silty, gray $\ldots \ldots \ldots \ldots .$. & 25 & 514 \\
19 & 244 & Shale, gray, blue and brown... & 46 & 560 \\
36 & 280 & (no water) & & \\
76 & 356 & & \\
\hline
\end{tabular}

Well A3-2-3bdb

Topsoil Sand and gravel.

Shale, sandy, gray ..............

Shale, sandy, blue ..............

Shale, sandy, gray ..............

Shale, blue and yellow.........

Water sand (15 gpm, 5,200 ppm).

Sandstone, yellow.

Shale, sandy, gray

Water sand (10 gpm, 3,850 ppm).

Shale, blue

\section{3}

12

7

11

7

1

21

28

16

30
Shale, sandy, gray ............. 2

Shale, blue, light-green and

brown .................... 14

Shale, sandy, gray (smells like

crude oil) ................. $\quad 20 \quad 177$

Sandstone, gray _................. 9

Shale, sandy, gray ............. $21 \quad 207$

Sandstone, gray ............... 990

Water sand (5 gpm, $700 \mathrm{ppm}) \ldots \quad 20 \quad 236$

Shale, sandy, blue........... $\quad 2 \quad 238$

Well A3-2-7cda

Topsoil, sandy (water) ........ 27

Sandrock, soft, yellow ..........

Shale, sandy, soft, gray ........

Sandstone, soft, yellow ..... . . .

Shale, sticky, blue........... . .

Shale, sandy, hard, light-blue.

Shale, sandy, soft, gray .........

Shale, sandy, soft, blue ......... .

Shale, sandy, gray, medium-

hard. ......................

Shale, sandy, soft, blue .......

Shale, sandy, soft, gray ........

Shale, sandy, grax, hard........

Shale, sandy, soft, blue.
Shale, sandy, hard, gray ....... 2 Shale, sandy, soft, blue; witl brown shale............... 12 Rock, hard, gray ............ . . 18 Shale, sandy, medium-gray..... $\quad 20$ Shale, sandy, soft, blue ........ 12 Shale, sandy, hard, gray ........ $\quad 28$ Shale, blue, soft ................ 6 Shale, sandy, medium-blue ..... 19 Shale, sandy, blue, coarse and muddy .................. 3 Shale, sandy, sticky, blue . ..... 5 Shale, soft, blue and brown..... $\quad 15$ Shale, soft, gray .............. 5 
TABLE 4.-Drillers' logs of wells-Continued

\begin{tabular}{|c|c|c|c|c|c|}
\hline Material & $\begin{array}{c}\text { Thick- } \\
\text { ness } \\
\text { (feet) }\end{array}$ & $\begin{array}{c}\text { Depth } \\
\text { (feet) }\end{array}$ & Material & $\begin{array}{c}\text { Thick- } \\
\text { ness } \\
\text { (feet) }\end{array}$ & $\begin{array}{c}\text { Depth } \\
\text { (feet) }\end{array}$ \\
\hline \multicolumn{6}{|c|}{ Well A3-2-7cda-Continued } \\
\hline $\begin{array}{l}\text { Shale, sandy, hard, gray } \\
\text { Shale, sandy, medium-hard, } \\
\text { gray............................ } \\
\text { Sandstone, soft, red and gray } \\
\text { Shale, sandy, sticky, soft, gray - } \\
\text { Sandstone, soft, gray and red } \\
\text { (small amount of water) }\end{array}$ & $\begin{array}{r}11 \\
32 \\
48 \\
2\end{array}$ & $\begin{array}{l}350 \\
398 \\
400\end{array}$ & 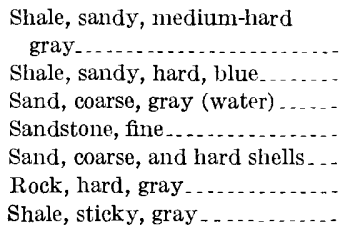 & $\begin{array}{r}38 \\
3 \\
11 \\
9 \\
22 \\
2 \\
4\end{array}$ & $\begin{array}{l}449 \\
452 \\
463 \\
472 \\
494 \\
496 \\
500\end{array}$ \\
\hline
\end{tabular}

\section{Well A3-2-32cbb}

Clay, sandy

\begin{tabular}{rr|}
10 & 10 \\
25 & 35 \\
30 & 65 \\
15 & 80 \\
45 & 125
\end{tabular}

Sandstone................. $40 \quad 165$

Sandstone and shale..............

Sandstone..................... . 30

Shale

Sandstone and shale........... 45

$\begin{array}{rr}40 & 165 \\ 150 & 315\end{array}$

Shale, hard................ $140 \quad 455$

Sandstone (water)

Shale

\section{Well A3-6-15bcb}

Clay, fine gravel, and cobbles... $\quad 12$ Sandstone, broken . . . . ........ $\quad 15$ Siltstone, sandstone, and shale _. $\quad 20$ Sandstone, brown............ 30 Shale, siltstone, fine sandstone.. Sandstone, gray ................. Siltstone, sandstone, and shale.. Sandstone, gray ................ Siltstone, very hard and bluish.
Sandstone, gray Sandstone, siltste, and shale. y, coarse, white Sandstone, medium, white .... . Siltstone, sandstone, and shale. . Sandstone and blue shale....... Sandstone, medium, white ..... Sandstone, coarse, white

(water)

\section{Well A4-2-12ddd}

Topsoil, sandy . . .............. 2

Shale, sanđy, gray ............. Shale, sandy, dark-gray . . . .....

Shale, sandy, gray (10 gpm at

$40 \mathrm{ft}, 5,950 \mathrm{ppm}$ at $50 \mathrm{ft}$ ) . . . . . .

Sandstone, yellow (90 gpm at

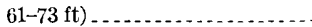

Shale, sandy, gray $(4,200 \mathrm{ppm}$

at $80 \mathrm{ft}) \ldots \ldots \ldots$

Shale, sandy, blue.............

Shale, sandy, gray (12 gal/hr,

$132 \mathrm{ft}-150 \mathrm{ft}$ ) . . . . . . . . . . . . . . .

Shale, sandy, brown $\ldots . . . . . . .$.

Shale, sandy, gray ..............

Shale, sandy, red-brown........

Shale, sandy, gray ...............
Shale, blue and brown _....... $\quad 4 \quad 407$

Shale, sandy, gray............ 815

Shale, brown _.............. 50

Shale, sandy, red-brown_...... $\quad 8 \quad 228$

Shale, sandy, gray, hard $\ldots \ldots . . .67 \quad 67 \quad 295$

Shale, brown .................. $\quad 3 \quad 298$

Shale, sandy, gray, hard ....... $\quad 20 \quad 318$

Shale, sandy, dark-gray........ $\quad 14 \quad 332$

Shale, sandy, gray, medium-

gray

Shale, blue and brown, carey . .. $\quad 6 \quad 364$

Shale, sandy, brown . . ......... $11 \quad 375$

Shale, brown $\ldots . . \ldots \ldots 1$

Shale, sandy, gray, hard....... $\quad 5 \quad 586$

Shale, brown and blue ......... $12 \quad 398$

Shale, sandy, gray, hard....... $\quad 2 \quad 400$ 
T.1BLE 4.-Drillers' logs of wells-Continued

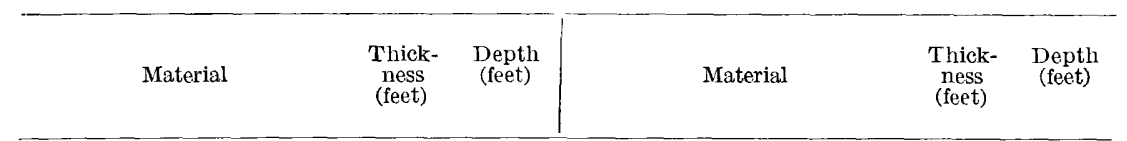

\section{Well A4-3-5dcb}

\section{Sandstone, yellow and gray} (hardwater)

Shale, gray, brown, green, yellow . . . . . Sandstone, gray ...............

Shale, gray . ................. Sandstone with lime shells.....

$\begin{array}{lr}41 & 41 \\ 22 & 63 \\ 32 & 95 \\ 25 & 120 \\ 20 & 140\end{array}$

Shale, gray _........... - 10 Shale, gray _........ 195 Sandstone, gray . . . Shale, gray and brown . . ....... $63 \quad 270$ Sandstone, gray _........... 5 . 5 Shale, gray and brown ........ $50 \quad 325$

\section{Well A4-3-11acd}

Sand and gravel............. 10

Shale, sandy, gray _............ 30

Sandstone ..................... 20

Shale, gray, sandy ............. $\quad 27$

Sandstone, gray . . ............. 3

Shale, gray ................... 21

IIard shell of rock ............. 2

Sandstone, gray, soft. ........ 17

Shale, gray, hard.............

Water sand $(2,800 \mathrm{ppm}) \ldots . . . .$.

Sandstone, hard.
Sandstone, soft ............... 16

40

60

87

90

111

113

130

132

140

162
Shale, blue _

Shale, hrown _............... 897

Shale, sticky, light-gray _......... $\quad 18 \quad 215$

Sandstone, gray (water, 2,300

ppm)

Sand, soft (water, $1,890 \mathrm{ppm}$ ) .... $\quad 34 \quad 324$

Limestone, hard ............ 3327

Shale, very sandy (water) _...... $\quad 18 \quad 345$

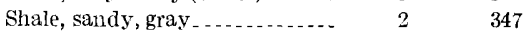

\section{Well A4-3-20abc}

Soil, sandy .................. 25

Sandstone, yellow .......... 32

Sandstone, gray ............. 11

Shale, brown ............. 5

Shale, saudy, gray_........... 13

sbale, brown ............... 4
Shale, sandy gray

Hard rock

Shale, sandy, blue and gray ..... $\quad 2 \quad 101$

Sandstone, gray . . . . . . . . . . 4 4

Shale, sandy, gray _.......... 99

Water sand ................ 82

\section{Well At-3-21bbe}

Soil _................ 7

Shale, sandy, gray............ 24

Sandstone, yellow........... 55

Shale, sandy, gray, blue, brown _ $\quad 32$

Sandstone (water) .......... 6

Shale, sandy, gray, blue,

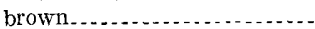

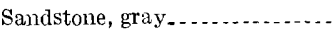

Shale, sandy, gray, blue,

brown_............ $57 \quad 348$

Sandstone, gray _............ $\quad 23 \quad 371$

Shale, sandy, gray, blue,

brown 64

Sandstone, coarse _............ 449

Shale, sandy, gray, blue,

brown.................... $351 \quad 790$

\section{Well A4-3-35adc}

Soil, sandy . . . . . . . . . . . .

Sand and gravel..............

Shale, sandy, blue...........

Sandstone, yellow. .............

Shale, sandy, gray and blue...-

Sandstone (water) . ............

Shale, sandy, blue and gray ....
Sandstone, gray-_............ $\quad 23 \quad 195$

Shale, blue $\ldots$............... $19 \quad 214$

Sandstone (softer water)....... $\quad 9 \quad 223$

Shale, gray, blue and brown.... $\quad 64 \quad 287$

Sandstone (water) . ........... $\quad 25 \quad 312$

Shale, sandy, gray $\ldots . . . . . . . . .315$ 
T.ABLE 4.-Drillers' logs of wells-Continued

\begin{tabular}{|c|c|c|c|c|c|}
\hline Material & $\begin{array}{c}\text { Tlick- } \\
\text { ness } \\
\text { (feet) }\end{array}$ & $\begin{array}{l}\text { Depth } \\
\text { (feet) }\end{array}$ & Material & $\begin{array}{c}\text { Thick- } \\
\text { ness } \\
\text { (feet) }\end{array}$ & $\begin{array}{l}\text { Depth } \\
\text { (feet) }\end{array}$ \\
\hline
\end{tabular}

\section{Well B1-1-5acb1}

\begin{tabular}{|c|c|c|c|c|c|}
\hline Surface $\ldots \ldots \ldots \ldots$ & 7 & 7 & Sand and gravel ............. & 1 & 35 \\
\hline Quicksand . . . . & 13 & 20 & Shale. & 5 & 40 \\
\hline Clay, broke'n _ & 14 & 34 & & & \\
\hline \multicolumn{6}{|c|}{ Well B1-1-31add } \\
\hline Surface. & 2 & 2 & Broken shale (water) . . . . . . . . & 13 & 50 \\
\hline Rock and clay $\ldots \ldots \ldots$ & 10 & 12 & Shale.... & 32 & 82 \\
\hline Shale__... & 25 & 37 & Broken shale & 8 & 90 \\
\hline
\end{tabular}

Well B1-2-26add

\begin{tabular}{|c|c|c|c|c|c|}
\hline Surface $\ldots . . . . . \ldots \ldots \ldots \ldots$ & 1 & 1 & Sand and boulders (water) ..... & 13 & 28 \\
\hline 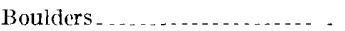 & 14 & 15 & & & \\
\hline
\end{tabular}

\section{Well B1-2-26cbd}

Surface.................

Rock and clay . . 20

1 Quicksand ................

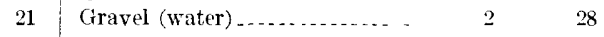

\section{Well B1-2-35baa}

\begin{tabular}{|c|c|c|c|c|c|}
\hline Surface. & 1 & 1 & 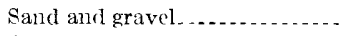 & 3 & $2 \cdot 2$ \\
\hline Rock and clay ................... & 16 & 17 & Clay, lirown $\ldots \ldots$ & 2 & 24 \\
\hline Rock and gravel . .... . . . . . & 2 & 19 & Shale $\ldots \ldots \ldots$ & 10 & 34 \\
\hline
\end{tabular}

\section{Well B1-2-36cbb}

Surface................ _... 3

Clay, hrow11.............. 12

Boulders
3

15

18

Clay, y ellow _............. 13

Gravel (water) ... ......... 36

\section{Well B2-2-26aca}

Gravel_................... 12

Clay, yellow

12

Sand (water) 
TABLE 4.-Drillers' logs of wells-Continued

\begin{tabular}{|c|c|c|c|c|c|}
\hline Material & $\begin{array}{l}\text { Thick- } \\
\text { ness } \\
\text { (feet) }\end{array}$ & $\begin{array}{l}\text { Depth } \\
\text { (feet) }\end{array}$ & Material & $\begin{array}{c}\text { Thick- } \\
\text { ness } \\
\text { (feet) }\end{array}$ & $\underset{\text { (feet) }}{\text { Depth }}$ \\
\hline
\end{tabular}

Well B2-2-31cda2

\begin{tabular}{|c|c|c|c|c|c|}
\hline Surface & 2 & 2 & Gravel (water) & 6 & 36 \\
\hline Clay, brown & 18 & 20 & Shale....... & 3 & 39 \\
\hline Clay, yellow & 10 & 30 & & & \\
\hline
\end{tabular}

\section{Well B4-3-32dcd}

Topsoil with a few rocks........ 12

Shale, sandy, light-blue.......... $\quad 6$

Shale, sandy, gray $\ldots . . . . . . . . . . .29$

Shale, sandy, light-brown_..... $\quad 3$
Shale, sandy, gray .............. 25

Shale, sandy, light-blue

Sand........................ $15 \quad 95$

Shale, sandy, gray-_._....... 500

\section{Well B4-4-14ccb}

Gravel. . . . . . . Shale, sandy, light-brown...... Shale, sandy, gray (2 gpm at

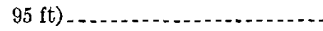
Shale, sandy, brown........... Shale, sandy, gray ............... Water sand (2 gpm)

Shale, blue and brown........... Shale, sandy, blue............. Shale, sandy, gray ............... Shale, brown and blue.

$\begin{array}{rr}54 & 54 \\ 33 & 87 \\ 13 & 100 \\ 10 & 110 \\ 19 & 129 \\ 19 & 148 \\ 29 & 177 \\ 7 & 184 \\ 22 & 206 \\ 5 & 211\end{array}$

Shale, sandy, light-blue......... $\quad 15 \quad 226$

Shale, sandy, gray.............. $\quad 22 \quad 248$

Water sand (4 gpm)

Shale, sandy, gray.............- $\quad 27 \quad 283$

Shale, blue and brown.......... $\quad 32 \quad 315$

Shale, sandy, gray

Water sand (main water, soft) _. $\quad 7 \quad 7 \quad 329$

Shale, sandy, hard, gray........ $\quad 30 \quad 359$

Shale, light-brown........... $6 \quad 6 \quad 365$

Shale, sandy, hard, gray; with

lime mixed................. $35 \quad 400$

\section{Well B4-4-16ada}

Soil, sandy, and rocks

Boulders, sand (small amount

of water) ...........................

Shale, blue.......................

Sandstone, light-brown

\begin{tabular}{rr|}
30 & 30 \\
12 & 42 \\
3 & 45 \\
12 & 57
\end{tabular}

Shale, gray $\ldots \ldots \ldots \ldots$

Shale, blue and brown......... $\quad 15 \quad 80$

Sandstone, gray ............... $\quad 30 \quad 110$

Water sand, coarse............. $\quad 20 \quad 130$

\section{Well B4-4-24cbc}

Rocks, sand, and gravel (water from 20-30 ft). Sandrock, brown

30 \begin{tabular}{ll|}
30 & 30 \\
10 & 40
\end{tabular}

Sandrock, red-brown

6

\section{Well B5-6-35ada}

Gravel, boulders, sandy clay, with streaks of shale; very unconsolidated material.......

\section{Sandstone with hard stringers} (water increased slightly on hard stringers) 
TABLE 4.-Drillers' logs of wells-Continued

\begin{tabular}{|c|c|c|c|c|c|}
\hline Material & $\begin{array}{c}\text { Thick- } \\
\text { ness } \\
\text { (feet) }\end{array}$ & $\begin{array}{l}\text { Depth } \\
\text { (feet) }\end{array}$ & Material & $\begin{array}{l}\text { Thick- } \\
\text { ness } \\
\text { (feet.) }\end{array}$ & $\begin{array}{l}\text { Depth } \\
\text { (feet) }\end{array}$ \\
\hline \multicolumn{6}{|c|}{ Well C1-1-4abd } \\
\hline Surface & 1 & 1 & Sand and gravel (water) & 3 & 20 \\
\hline Boulders. & 13 & 14 & Shale.................... & 3 & 23 \\
\hline Sand............. & 3 & 17 & & & \\
\hline \multicolumn{6}{|c|}{ Well C1-1-4adc } \\
\hline Surface............. & 1 & 1 & Quicksand............. & 1 & 21 \\
\hline Gravel and clay & 19 & 20 & Gravel (water) & 3 & 24 \\
\hline \multicolumn{6}{|c|}{ Well C1-1-5dab } \\
\hline Surface & 2 & 2 & Shale & 13 & 41 \\
\hline 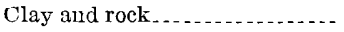 & 20 & 22 & Shale, sandy $(1 \mathrm{gpm})$ & 2 & 43 \\
\hline Quicksand (water) & 6 & 28 & Shale & 107 & 150 \\
\hline \multicolumn{6}{|c|}{ Well C1-1-5dba } \\
\hline Surface & 1 & 1 & Boulders, hard & 3 & 27 \\
\hline Rock & 17 & 18 & Sand (water) & 3 & 30 \\
\hline 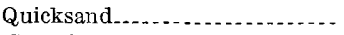 & 4 & 22 & Shale.................... & 12 & 42 \\
\hline Gravel and clay & 2 & 24 & & & \\
\hline
\end{tabular}

\section{Well C1-1-6edd}

\begin{tabular}{|c|c|c|c|c|c|}
\hline (-1, & 3 & 3 & Shale and gravel................... & 2 & 27 \\
\hline 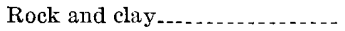 & 15 & 18 & Shale, black . . . . . . . & 11 & 38 \\
\hline Gravel (dry) & 7 & 25 & Shale, sandy, blue (water) ...... & 24 & 62 \\
\hline
\end{tabular}

\section{Well C1-1-6dde}

\begin{tabular}{|c|c|c|c|c|c|}
\hline - & 3 & 3 & Clay and gravel. & 7 & 20 \\
\hline Rock and gravel & 7 & 10 & Sand and gravel (water) ........ & 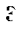 & 23 \\
\hline Gravel_. & 3 & 13 & & & \\
\hline
\end{tabular}

Well C1-1-7dcb

\begin{tabular}{|c|c|c|c|c|c|}
\hline Clay, brownl... & 20 & 20 & Sand and gravel $\ldots \ldots$ & 7 & 40 \\
\hline 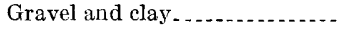 & 13 & 33 & Shale $\ldots . . .6$. & 3 & 43 \\
\hline
\end{tabular}

\section{Well C1-1-8aab}

Surface....................... 2

Rock and clay................ 20 
TABLe 4.-Driller's' logs of wells-Continued

\begin{tabular}{|c|c|c|c|c|c|}
\hline Material & $\begin{array}{c}\text { Thick- } \\
\text { ness } \\
\text { (feet) }\end{array}$ & $\begin{array}{l}\text { Depth } \\
\text { (feet) }\end{array}$ & Material & $\begin{array}{c}\text { Thick- } \\
\text { ness } \\
\text { (feet) }\end{array}$ & $\begin{array}{l}\text { Depth } \\
\text { (feet) }\end{array}$ \\
\hline
\end{tabular}

\section{Well C1-1-8ada}

\begin{tabular}{|c|c|c|c|c|c|}
\hline Surface $\ldots \ldots$ & 1 & 1 & Clay, red, and rock (water)..... & 8 & 13 \\
\hline Clay $\ldots \ldots \ldots$ & 4 & 5 & Gravel $\ldots \ldots \ldots \ldots$ & 7 & 20 \\
\hline
\end{tabular}

\section{Well C1-1-8ccb}

Topsoil....................... 3

Gravel...................... 31.5

Shale, dark................. . 29.5

Sand, soft .................. 13

Sand (carrying water)........

Sand ..............................

Shale, blue ..................

Shale, gray . ..................

Bentonite ....................

Shale, blue...................

Coal and sand.

Shale, gray -.................

Shale, black
6
20

20
67

67
31

1

2

3

20

14
3

Shale, gray ...

34.5 Shale, black _................. $35 \quad 295$

64 Shale, sandy, gray_............ 500

77 Limestone, hard, white........ $\quad 5 \quad 305$

83 Shale, gray.................. $17 \quad 17 \quad 322$

103 Shale, hard, gray _............. $\quad 28 \quad 350$

170 Shale, hard, light-gray ......... $50 \quad 500$

201 Shale, hard, black ............ $\quad 92 \quad 492$

202 Shale, sandy, gray ............. 50.59

204 Sand, gray, fine (water) ...... $\quad 17 \quad 514$

$207 \quad$ Sand, gray................. $\quad 29 \quad 543$

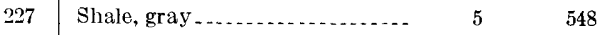

\section{J 98}

WATER SUPPLY OF INDIAN RESERVATIONS

TABLE 4.-Drillers' logs of wells-Continued

\begin{tabular}{|c|c|c|c|c|c|}
\hline Material & $\begin{array}{l}\text { Thick- } \\
\text { ness } \\
\text { (feet) }\end{array}$ & $\begin{array}{l}\text { Depth } \\
\text { (feet) }\end{array}$ & Material & $\begin{array}{c}\text { Thick- } \\
\text { ness } \\
\text { (feet) }\end{array}$ & $\begin{array}{l}\text { Depth } \\
\text { (feet) }\end{array}$ \\
\hline \multicolumn{6}{|c|}{ Well C1-2-13ddd } \\
\hline Clay. & 5 & 5 & Shale, blue $\ldots \ldots$ & 21 & 56 \\
\hline Rock and gravel. & 15 & 20 & Shale, red. & 6 & 62 \\
\hline Clay, pink & 15 & 35 & Shale, blue & 8 & 70 \\
\hline
\end{tabular}

\section{Well C1-2-24ada}

Rock and clay................ 7

Shale, brown 11

Shale, gray -
Shale, sandy (water, 2 gpm) ....

Shale, gray................ 10

Shale, sandy (water, $40 \mathrm{gpm}$ )...

$\begin{array}{rl}5 & 26 \\ 10 & 36 \\ 5 & 41\end{array}$

\section{Well C1-2-24dcb}


WIND RIVER INDIAN RESERVATION, WYOMING

Table 4.-Drillers' logs of wells-Continued

\begin{tabular}{|c|c|c|c|c|c|}
\hline Material & $\begin{array}{l}\text { Thick- } \\
\text { ness } \\
\text { (feet) }\end{array}$ & $\begin{array}{l}\text { Depth } \\
\text { (feet) }\end{array}$ & Material & $\begin{array}{l}\text { Thick- } \\
\text { ness } \\
\text { (feet) }\end{array}$ & $\begin{array}{l}\text { Depth } \\
\text { (feet) }\end{array}$ \\
\hline \multicolumn{6}{|c|}{ Well D1-1-15add } \\
\hline $\begin{array}{l}\text { Clay } \ldots \ldots \\
\text { Clay, sandy } \ldots \ldots \ldots\end{array}$ & $\begin{array}{r}20 \\
3\end{array}$ & $\begin{array}{l}20 \\
23\end{array}$ & $\begin{array}{l}\text { Gravel and sand } \ldots \ldots \ldots \\
\text { Shale, blue }\end{array}$ & $\begin{array}{l}5 \\
3\end{array}$ & $\begin{array}{l}28 \\
31\end{array}$ \\
\hline \multicolumn{6}{|c|}{ Well D1-1-15ccc } \\
\hline $\begin{array}{l}\text { Clay, brown } \\
\text { Sand and gravel } \ldots \ldots \ldots\end{array}$ & $\begin{array}{l}13 \\
25\end{array}$ & $\begin{array}{l}13 \\
38\end{array}$ & Shale, black $\ldots \ldots \ldots$ & 1 & 39 \\
\hline \multicolumn{6}{|c|}{ Well D1-1-16acb } \\
\hline $\begin{array}{l}\text { Surface } \ldots \ldots \\
\text { Clay } \ldots \ldots \\
\text { Shale, sandy }\end{array}$ & $\begin{array}{r}5 \\
20 \\
10\end{array}$ & $\begin{array}{r}5 \\
25 \\
35\end{array}$ & $\begin{array}{l}\text { Shale, light-gray } \ldots \\
\text { Shale, blue }\end{array}$ & $\begin{array}{l}25 \\
27\end{array}$ & $\begin{array}{l}60 \\
80\end{array}$ \\
\hline
\end{tabular}

\section{Well D1-1-21add}

\begin{tabular}{ll|ll} 
Surface $\ldots \ldots \ldots$ & 3 & Gravel and sand $\ldots \ldots \ldots \ldots$ & \\
\end{tabular}

\section{Well D1-1-22bce}

\begin{tabular}{|c|c|c|c|c|c|}
\hline Surface ............. & 8 & 8 & 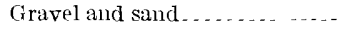 & 15 & 23 \\
\hline
\end{tabular}

\section{Well D1-1-30dba}

Clay .................... 10

Sand and gravel............. 10

Shale........................... 185

Shale with sandstone stringers. . $\quad 180$

\begin{tabular}{|c|c|c|}
\hline 10 & Shale........ & 331 \\
\hline 20 & Shale with bentonite. & 140 \\
\hline & Shale with sandstone stringers_. & 160 \\
\hline
\end{tabular}

\section{Well D1-2-9bbb1}

No $\log \ldots \ldots \ldots$ Shale, sandy, brown, soft....... 25 Shale, sandy, gray, soft........ 55 Shale, sandy, brown .......... 47 Coal ...................... 1 Shale, sandy, brown, dark..... $\quad 7$ Shale, sandy, gray, soft....... 38 Shale, sandy, coarse (no water) _ $\quad 9$
Coal and dark sandy shale___ $\quad 7 \quad 349$ Shale, sandy, gray, soft... _ _ $\quad 13 \quad 362$ Hard layer of rock . ... _.... 365 Sandstone, gray. with red specks (soft water) _......... $47 \quad 412$ Shale, sandy, brown, soft...... $\quad 8 \quad 420$ Shale, sandy, gras , soft ....... $10 \quad 10$ 
T.BLE 4.-Drillers' logs of wells-Continued

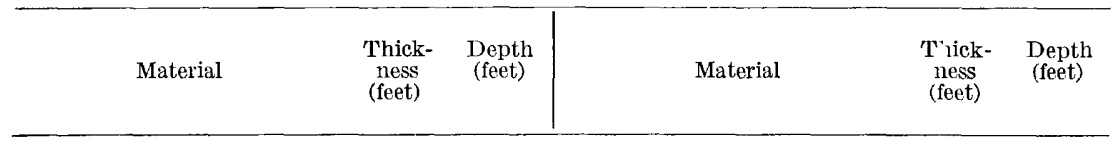

\section{Well D1-2-10-dcc}

Soil, sandy _...

Sand, gravel (water)

Sandstone, yellow . .

Shale, blue

Shale, gray .............. 30

Shate, brown and blue.......

Shale, soft, light-gray ...........

Shale, sandy, soft, gray ........

Shale, soft, light-gray

Shale, sandy, hard, gray _.......

Shale, soft, brown and gray....

Shale, soft, brown and blue... - .

Shale, sandy, gray ............

Shale, brown . .................

Shale, sandy, soft, gray ........ .

Shale, brown ................
Shale, yellow _........... 6

Shale, gray . . . . 12

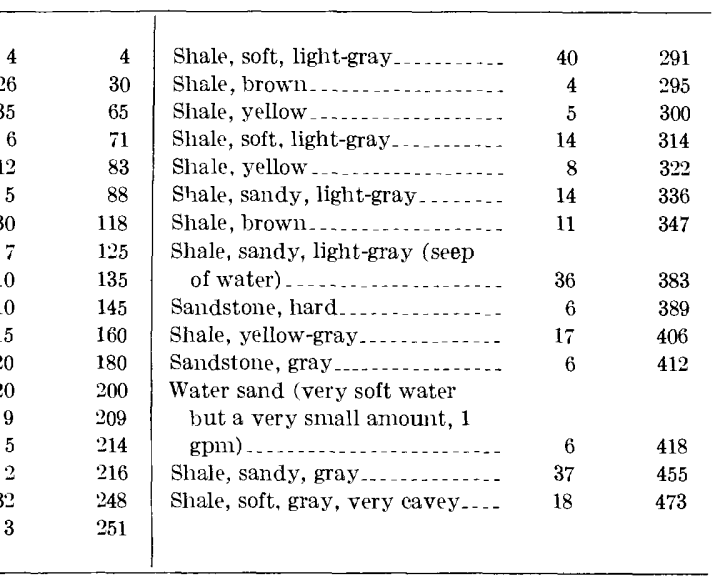

\section{Well D1-3-10cca}

Topsoil, sandy

Shale, sandy, yellowish-gray

(water, 4 gpm at $47 \mathrm{ft}, 542$

ppm)

Shale, sandy, gray ............

Shale, sandy, blue.............

Shale, sandy, gray ............

Shale, sandy, blue ...........

Shale, sandy, gray .............

Shale, sandy, blue .............

Shale, sandy, gray ...............

$\begin{array}{rr}20 & 20 \\ 10 & 30 \\ & \\ 28 & 58 \\ 68 & 126 \\ 30 & 156 \\ 6 & 162 \\ 10 & 172 \\ 11 & 183 \\ 21 & 204 \\ 32 & 236\end{array}$

Shale, sandy, blue............ 8

Sand, gray (water, $20 \mathrm{gpm}$,

$446 \mathrm{ppm}$ )

Shale, sandy, blue and brown.- $\quad 11 \quad 264$

Shale, sandy, bluish-gray ...... $\quad 36 \quad 300$

Shale, sandy, blue............ $14 \quad 314$

Shale, sandy, bluish-gray......- $\quad 16 \quad 330$

Sandstone, gray, very fine sand. $\quad 20 \quad 350$

Shale, sandy, blue and brown _ $\quad 25 \quad 375$

Sand, gray (principal water

bed, $434 \mathrm{ppm}$ )

\section{Well D1-3-12dba}

Topsoil and dirt, rocks . ......... 6

Shale, blue.................. 9

Sandstone, yellow, very shaly _. 8

Sandstone, brown.......... 12
Sand, brown_................. $\quad 5 \quad 40$

Shale, sandy, brown........... $\quad 5 \quad 45$

Shale, sandy, gray .............. 50

Shale, gray, and bentonite...... $\quad 5 \quad 55$

\section{Well D1-3-13dad}

Topsoil, sandy

Gravel and water........... 8

Shale, red-brown.............. 9

Bentonite
Shale, sandy, gray $\ldots \ldots \ldots \ldots . . . . . .29$

Sand, fine, gray (water) ........ 10

Shale, sandy, gray ............. 15
55

65

80 
TABLE 4.-Drillers' logs of wells-Continued

\begin{tabular}{|c|c|c|c|c|c|}
\hline Material & $\begin{array}{l}\text { Thick- } \\
\text { ness } \\
\text { (feet) }\end{array}$ & $\begin{array}{l}\text { Depth } \\
\text { (feet) }\end{array}$ & Material & $\begin{array}{c}\text { Thirk- } \\
\text { ne:ss } \\
\text { (feet) }\end{array}$ & $\begin{array}{c}\text { Depth } \\
\text { (feet) }\end{array}$ \\
\hline \multicolumn{6}{|c|}{ Well D1-3-14abb } \\
\hline Soil, sandy, and gravel.......... & 5 & 5 & Sand & 10 & 30 \\
\hline Shale, yellowish-gray .......... & 15 & 20 & Shale, reddish-gray & 10 & 40 \\
\hline \multicolumn{6}{|c|}{ Well D1-3-23bcc } \\
\hline Topsoil, sandy $\ldots \ldots$ & 6 & 6 & Shale, sandy, gray & 16 & 97 \\
\hline Sand, gravel (hard water)..... & 14 & 20 & Sand, gray (good water) & 20 & 117 \\
\hline Shale, sandy, gray ................. & 40 & 60 & Shale, sticky, brown and gray . - & 3 & 120 \\
\hline Shale, blue & 21 & 81 & & & \\
\hline
\end{tabular}

\section{Well D1-3-23bdd2}

Soil, sandy

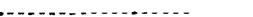

Gravel...................... 5

Shale, gray, soft........... 5

Sandstone, yellow............. 4

Shale, gray .................. 8

Sandstone, gray .............. 60

Shale, sandy, gray _...

Shale, sticky, gray . ............ $50 \quad 50$

Shale, brown.................. 10

Shale, sticky, gray_........... $15 \quad 175$

Shale, sandy, gray, hard....... $\quad 31 \quad 206$

Water sand and hard shells.... $\quad 44 \quad 250$

\section{Well D1-3-24cbb}

Soil $\ldots \ldots \ldots$

Gravel (water) $\ldots . . . . . . . . . .11$

Shale, sandy, blue, gray, brown_ $\quad 154$

Sandstone, gray ............... 15

Shale, sandy, blue........... 8

Sandstone, gray _............ 19

212

16 , Shale, sandy, blue ...........

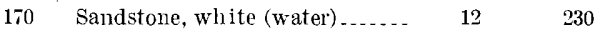

185 Shale, blue.................. 232

|

\section{Well 1-3-21cbd}

Topsoil, sandy

Gravel ......................

Sandrock, yellow (veins of hard water)

Shale, blue. ..................

Shale, sandy, gray (water at 55

ft. Fairly hard and tastes

Shale, blue

Shale, gray ......................

Shale, blue.

4
8
12
3
58
31

4

8

12

3
Shale, sandy, gray ............... $\quad 6 \quad 131$

Shale, sandy, blue............. $11 \quad 142$

Shale, blue and brown . . . . . . . $\quad 2 \quad 144$

24 Shale, sandy, gray ............. 5059

27 Shale, blue and brown ........ $31 \quad 3180$

Shale, sand $y$, gray ........... . $20 \quad 200$

Sandrock, gray; with hard
shells............ $20 \quad 220$

Sand, white (water) . .......... $10 \quad 230$

Shale, sandy, blue................ 5

\section{Well D1-3-24cda}

Soil, sandy

Gravel .

Shale, sandy; alterna

blue brown, yellow

Sandstore, coarse (small flow)..

8

Shale, blue .................. $\quad 6 \quad 238$

Sandstone, bluish-white...... $\quad 8 \quad 246$

Sandstone, brown............ $\quad 8 \quad 254$

Sandstone, white (main flow) ... $\quad 11 \quad 265$

Shale, brown ................. $\quad 2 \quad 267$ 
TABLE 4.-Drillers' logs of wells-Continued

\begin{tabular}{|c|c|c|c|c|c|}
\hline Material & $\begin{array}{l}\text { Thick- } \\
\text { ness } \\
\text { (feet) }\end{array}$ & $\underset{\text { (feet) }}{\text { Depth }}$ & Material & $\begin{array}{l}\text { Thick- } \\
\text { ness } \\
\text { (feet) }\end{array}$ & $\begin{array}{l}\text { Depth } \\
\text { (feet) }\end{array}$ \\
\hline
\end{tabular}

\section{Well D1-3-24cde}

\begin{tabular}{|c|c|c|c|c|c|}
\hline 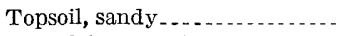 & 23 & 23 & Water sand (good for $60 \mathrm{gpm}$ & & \\
\hline Gravel (no water) $\ldots . . . . . . . . .$. & 3 & 26 & or better) & 10 & 50 \\
\hline Shale, sandy, gray $\ldots \ldots \ldots$ & 14 & 40 & & & \\
\hline
\end{tabular}

\section{Well D1-1-2cab}

\begin{tabular}{|c|c|c|c|c|c|}
\hline Topsoil, sandy $\ldots \ldots$ & 6 & 6 & Sand, fine, white $\ldots \ldots \ldots$ & 12 & 49 \\
\hline Gravel. & 10 & 16 & Shale, blue . . . . . . . . . . & 4 & 53 \\
\hline Shale, gray $\ldots$ & 15 & 31 & Shale, sandy, gray $\ldots \ldots \ldots$. & 12 & 65 \\
\hline Shale, sandy, gray & 6 & 37 & & & \\
\hline
\end{tabular}

\section{Well D1-1-3dcb}

Topsoit, sandy . . . 3

Gravel_.................... 11

Shale, sandy, blue............

Shale, sandy, gray, hard........ 30

Shale, blue................. 4

Shale, sandy, gray $\ldots . . . . . . . . . . \quad 26$
Shale, sandy, blue_.......... $15 \quad 15 \quad 98$

Shale, sandy, gray............ $14 \quad 14$

Shale, sandy, blue, very hard..- $\quad 8 \quad 120$

Sand (water) ............. $10 \quad 130$

Shale, sandy, gray

\section{Well D1-1-1ccd}

Gravel...................... 9

Sandstone, hard layers........ 3

Shale, bluish-gray_............ 8

Sandstone, gray (water) ....... 18
Shale, sandy, blue............ 31

Sandstone, gray (water) _...... $14 \quad 55$

Shale, sandy, gray............ 83

\section{Well D1-4-tcdd}

Topsoil, sandy

Gravel (water bearing)

Sandstone, hard .............

Shale, sandy, soft, gray.........

Sandstone, hard

Shale, sandy, gray ..............

Shale, blue ..................

Shale, sandy, gray $\ldots . . . . . . . . .$.

Sand (water bearing) ........... .

Shale, sandy, gray ...........

Shale, sandy, sticky, gray ......

Shale, sandy, gray .............

Rock, hard, white............

Shale, sandy, gray

Shale, sandy, blue..............

Shale, sandy, gray .............

Shale, soft, sticky, blue.........

Shale, sandy, gray ...............

Shale, soft, blue

\begin{tabular}{|c|c|c|}
\hline Shale, gray, sandy..... & 18 & 198 \\
\hline Shale, sandy, blue..... & 2 & 200 \\
\hline Shale, sandy, gray $\ldots . . .$. & 3 & 203 \\
\hline Shale, soft, blue....... & 6 & 209 \\
\hline Shale, sandy, gray & 9 & 218 \\
\hline \multicolumn{3}{|l|}{ Shale, sandy gray, red and } \\
\hline brown sand............... & 18 & 236 \\
\hline Shale, soft, blue $\ldots \ldots \ldots$ & 4 & 240 \\
\hline Shale, sandy, soft, gray ... & 8 & 248 \\
\hline Shale, very sandy, gray & 7 & 255 \\
\hline Shale, soft, blue $\ldots$ & 4 & 259 \\
\hline Shale, sandy, soft, gray..... & 7 & 266 \\
\hline Shale, soft, blue & 2 & 268 \\
\hline Shale, sandy, gray & 5 & 273 \\
\hline Shale, sandy, blue........... & 8 & 281 \\
\hline Shale, soft, dark-brownish-blue & 2 & 283 \\
\hline Shale, soft, reddish-brown & 9 & 292 \\
\hline Shale, sandy, blue............ & 5 & 297 \\
\hline Shale, soft, reddish-brown & 13 & 310 \\
\hline
\end{tabular}


TABLe 4.-Dillers' logs of wells-Continued

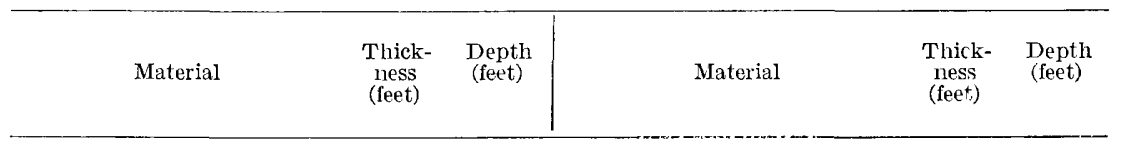

\section{Well D1-1-4cdd-Continued}

Shale, sandy, blue. $\ldots . . . . . . . \quad 4$

Shale, sandy, gray ............. 6

Sand, gray (water bearing,

well flowed $9 \mathrm{gpm}$ ) . . . . . . . . .

Sandstone, hard, brown ....... . 5

Shale, hard, reddish-brown _... $\quad 9$

Shale, hard, blue ............. . 4

Shale, hard, reddish-brown

Shale, blue and brown mixed... $\quad 2$

314

320

338

346

351

360

364

378

380
Shale, sandy, hard, blue........ $\quad 5 \quad 385$

Sand, gray (water bearing,

flow increased to $100 \mathrm{gpm}$ ).... $35 \quad 420$

Shale, sandy, hard, blue........ $\quad 3 \quad 423$

Sand, gray (water hearing) . .... 430

Shale, sandy, hard, blue ........ $\quad 5 \quad 435$

Sand, gray (water bearing) . . . . . 3438

Sandstone, gray ............ $\varepsilon \quad 446$

Sand and blue medium-hard

shale.................. 4450

\section{Well D1-1-1ddd}

Topsoil, sandy _........... 3

Gravel ................ ... 14

Shale, sandy, gray $\ldots . . .63$

Shale, sticky, gray _......... 40

Sandrock (water at $150 \mathrm{ft}$,

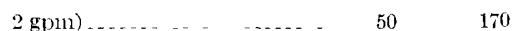

Shale, sandy, gray-_ $\quad \ldots \ldots \ldots-20 \quad 190$

Sandrock _............... $58 \quad 248$

Water sand (flow) $\ldots \ldots$

\section{Well D1-4-5bbb}

Topsoil, sandy _ _ _.. _ _ 66

Gravel ...... 8

Shale, sandy, gray ............ $\quad 26$
Sand, gray (water) $\ldots \ldots \ldots \ldots$

Shale, sandy, blue . ... . . . ..... $10 \quad 60$

\section{Well D1-1-7bbb}

Gravel

Sandstone, reddish-brow'n (seep

of hard water at $29 \mathrm{ft}$ )

Shale, gray and blue..........

Sandstone, gray, very coarse . . . .

Shale, sandy, gray.
15

50

126

143

163
Sandstone, gray (water, $3 \mathrm{gpm}$ ) _ $\quad \mathbf{1} \overrightarrow{\mathrm{i}} \quad 180$ Shale, alternating gray and blue. $\quad 50 \quad 230$ Sandstone, gray ............ $16 \quad 246$ Shale, alternating gray and blue_ $\quad 121 \quad 367$ Sandstone, gras(water) ...... . $\quad 15 \quad 3 飞 2$ Shale, blue ................ $\varepsilon \quad 390$

\section{Well D1-4-7dcb}

Topsoil, sandy . . .......... . 1

Gravel ............. _ 14

Shale, yellow-brown. ........ 8

Shale, sandy, brown .......... 17

Shale, pink................. 3
Shale, sandy, gray (water at 40

ft, 5 gpm) _........... 22

Sandrock, gray (water at $75 \mathrm{ft}, 5$

gpm, very hard) ........... if 75

Shale, sandy, gray ........... 7

Shale, blue _.............. 35 
TABLE 4.-Drillers' logs of wells-Continued

\begin{tabular}{|c|c|c|c|c|c|}
\hline Material & $\begin{array}{c}\text { Thick- } \\
\text { ness } \\
\text { (feet) }\end{array}$ & $\underset{\text { (feet) }}{\text { Depth }}$ & Material & $\begin{array}{c}\text { Thick- } \\
\text { ness } \\
\text { (feet) }\end{array}$ & $\begin{array}{l}\text { Depth } \\
\text { (feet) }\end{array}$ \\
\hline
\end{tabular}

\section{Well D1-4-9aad}

Gravel and water............. 14 Shale, sandy, gray, very coarse . Shale, sandy, blue ........... Shale, gray .................. Shale, blue .................... Sandstone, gray, witll red streaks.

Shale, sandy, hard, blue .......

\begin{tabular}{|c|c|c|c|}
\hline 14 & Shale, sandy, hard, gray . . . . . . . . & 45 & 180 \\
\hline 57 & Sandstone, gray (small amount & & \\
\hline 63 & of water at $185 \mathrm{ft}) \ldots \ldots \ldots$ & 32 & 212 \\
\hline 95 & Shale, sandy, blue $\ldots$ & 6 & 218 \\
\hline \multirow[t]{2}{*}{117} & Shale, sandy, gray & 17 & 235 \\
\hline & Sandrock, gray $\ldots$ & 15 & 250 \\
\hline 130 & Water sand & 15 & 265 \\
\hline 135 & Shale, brown and blue . . ........ & 2 & 267 \\
\hline
\end{tabular}

\section{Well D1-4-9cdc2}

Sand and gravel (water) _....... $\quad 17$ Sand, yellow (water) ..... . . . . . 13 Sandstone, gray, soft.......... 30 Sandstone, gray, hard . . . . . . . . $\quad 18$ Shale, blue and gray _......... $\quad 248$
Sandstone (soft water) _........ $\quad 13 \quad 339$ Shale, gray and blue _........... $\quad 136 \quad 475$ Sandstone (soft water) ......... $\quad 39 \quad 514$ Shale, brown ............... 1

\begin{tabular}{|c|c|c|c|c|c|}
\hline \multicolumn{6}{|c|}{ Well D1-4-9cde3 } \\
\hline Soil & 3 & 3 & Sandstone, yellow (water)...... & 39 & 57 \\
\hline Gravel (water) $\ldots \ldots$ & 15 & 18 & & & \\
\hline
\end{tabular}

\section{Well D1-4-18baa}

Sand, yellowish, and gravel Shale, brown and blue.... ..... Bentonite ...................... Shale, sandy, blue
Shale, sandy, gray (water at 60

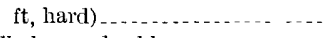
Shale, sandy, blue............ Shale, sandy, gray ............. Sand, blue, and coal shale ..... Shale, blue.

\begin{tabular}{|c|c|c|}
\hline Shale, sandy, blue & 25 & 190 \\
\hline Shale, blue $\ldots \ldots \ldots \ldots$ & 10 & 200 \\
\hline Shale, sandy, blue & 40 & 240 \\
\hline Sandstone, liglit-gray.......... & 25 & 265 \\
\hline Shale, sandy, light-blue......... & 17 & 28.2 \\
\hline Shale, sandy, light-gray ........ & 11 & 293 \\
\hline Shale, sandy, blue, hard........ & 13 & 306 \\
\hline Sand (main water) & 10 & 316 \\
\hline Shale, sandy, blue $\ldots \ldots \ldots \ldots$ & 4 & 320 \\
\hline
\end{tabular}

\section{Well D1-4-18bba}

Topsoil, sandy ............. $\quad 2$

Gravel_.................. 11

Shale, brown................ 11

Shale, sandy, gray ........... 5

Bentonite $(0-35$ very soft and

cavey) ......................

Shale, sandy, gray .............

Shale, sandy, coarse, gray

(water at $57 \mathrm{ft}, 3,312 \mathrm{ppm}$ ) ... .

Shale, sandy, blue...........

Shale, sandy, gray $\ldots . . . . . . .$.

Shale, sandy, blue............

Shale, sandy, gray ...........

\section{Shale, streaks of blue and}

brown

Shale, sandy, gray ............ $13 \quad 132$

Shale, gray _._.

Shale, blue, and coal........ . $\quad 3 \quad 147$

Shale, sandy, gray .............. $19 \quad 196$

Shale, sandy, blue.......... $11 \quad 177$

Shale, sandy, gray _......... 60.63

Shale, sandy, blue............. 64

Shale, sandy, gray ............. $3 \quad 3 \quad 192$

Shale, sandy, gray (114-198 ft,

soft and sticky) _............ 6

Shale, sandy, hard, gray _....... $\quad 11 \quad 209$ 
TABLE 4.-Drillers' logs of wells-Continued

\begin{tabular}{|c|c|c|c|c|c|}
\hline Material & $\begin{array}{c}\text { Thick- } \\
\text { ness } \\
\text { (feet) }\end{array}$ & $\begin{array}{c}\text { Depth } \\
\text { (feet) }\end{array}$ & Material & $\begin{array}{c}\text { Thick- } \\
\text { nass } \\
\text { (feet) }\end{array}$ & $\begin{array}{c}\text { Depth } \\
\text { (feet) }\end{array}$ \\
\hline \multicolumn{6}{|c|}{ Well D1-4-18bba-Continued } \\
\hline Shale, blue . . . . & 11 & 220 & Shale, sandy, gray, hard........ & 5 & 311 \\
\hline Shale, sandy, gray $\ldots \ldots$ & 17 & 237 & Shale, sandy, blue, hard ....... & 3 & 314 \\
\hline Shale, sandy, blue $\ldots . . . . . . .$. & 5 & 242 & Sand, gray $(378$ ppm) $\ldots \ldots$ & 10 & 324 \\
\hline Shale, sandy, gray $\ldots . . . . . .$. & 47 & 289 & Shale, sandy, blue, hard........ & 6 & 330 \\
\hline Shale, sandy, blue................ & 17 & 306 & & & \\
\hline
\end{tabular}

\section{Well D1-4-18bbd}

\begin{tabular}{|c|c|c|c|c|c|}
\hline Topsoil, saudy $\ldots$ & 8 & 8 & Shale, sandy, gray $\ldots \ldots \ldots \ldots$ & 4 & 40 \\
\hline Gravel_................. & 10 & 18 & Sand, gray (hard water) ....... & 5 & 45 \\
\hline $\begin{array}{l}\text { Shale, sandy, brown, very soft } \\
\text { Shale, yellowish-gray, very }\end{array}$ & 6 & 24 & Shale, sandy, gray .............. & 15 & 60 \\
\hline soft.... & 12 & 36 & & & \\
\hline
\end{tabular}

\section{Well D1-4-18daa}

Soil

Gravel. ..................... 15

Shale, yellow and gray ........ 56

Shale, gray, blue and green $\quad 129$

\section{Well D1-5-11ace}

Topsoil

Sand ... _............... 2

Clay, red................... 15

Sandstone ................... 7

Clay, blue ................... 32

Clay, red and blue ............ 59

Shale, sandy (first water at

$118 \mathrm{ft}$ )

(1)

Sand, good, coarse (second

water at $126 \mathrm{ft}$ )

Clay, sandy (carries water) ..... 3
Sand, good, coarse (third

water at $146 \mathrm{ft}$ ) $\ldots \ldots \ldots \ldots \ldots$

Clay, blue

Sand (fourth water at $154 \mathrm{ft}$ ) .... $\quad 2 \quad 156$

Clay, blue _.

Sand (fifth water) $\ldots \ldots \ldots \ldots \ldots$

Clay, red and blue............ $\quad 25 \quad 191$

Clay, sandy $\ldots \ldots 10$

Sand (sixth water at $191 \mathrm{ft}$ )..... $\quad 7 \quad 208$

Clay, blue................ 210

Sand (seventh water at $210 \mathrm{ft}$ ) _. $\quad 1 \quad 211$

Clay, blue.................. 11212

Sand (eighth water at $212 \mathrm{ft}$ ).... $\quad 3 \quad 3$

Clay, blue............... $10 \quad 225$

\section{Well D1-6-7bcd}

No log

Sandstone, fine to coarse, green

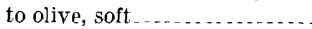

Claystone, sandy, green,

yellow, red .........................

Sandstone, fine to coarse, green

to light-gray, soft (water).

Claystone, sandy, greenish-

gray; bentonite.
60

60

60

Sandstone, fine to coarse, light-

gray, greenish-gray, uncon-

solidated, soft (water) _..... $120 \quad 680$

Claystone, sandy, greenish-

100

gray . . . . . . . . . . .

Sandstone, medium to coarse,

Claystone, sandy, greenish-

560

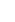
.

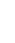

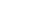




\section{WATER SUPPLY OF INDIAN RESERVATIONS}

TABLE 4.-Drillers' logs of wells-Continued

\begin{tabular}{|c|c|c|c|c|c|}
\hline Material & $\begin{array}{c}\text { Thick- } \\
\text { ness } \\
\text { (feet) }\end{array}$ & $\begin{array}{l}\text { Depth } \\
\text { (feet) }\end{array}$ & Material & $\begin{array}{l}\text { Thick- } \\
\text { ness } \\
\text { (feet) }\end{array}$ & $\begin{array}{l}\text { Depth } \\
\text { (feet) }\end{array}$ \\
\hline \multicolumn{6}{|c|}{ Well D1-6-7bcd-Continued } \\
\hline $\begin{array}{l}\text { Sand and claystone, greenish- } \\
\text { gray } \\
\text { Sandstone, very fine to } \\
\text { medium, light-gray, clayey, } \\
\text { soft (water) }\end{array}$ & 20 & 740 & $\begin{array}{l}\text { Claystone, sandy, green, } \\
\text { yellow, red.............. } \\
\text { Siltstone, light-gray, clayey...- } \\
\text { Shale, variegated, silty, sandy; } \\
\text { some chert.-................ }\end{array}$ & $\begin{array}{l}60 \\
70 \\
60\end{array}$ & $\begin{array}{r}830 \\
900 \\
960\end{array}$ \\
\hline \multicolumn{6}{|c|}{ Well D2-3-1cab } \\
\hline Shale, blue and brown & 14 & 14 & Shale, sandy, blue............. & 32 & 120 \\
\hline Shale, sandy, reddish-brown.... & 34 & 48 & Sand, coarse (water) & 22 & 142 \\
\hline Sandrock, yellow (bad water) _. & 40 & 88 & Shale, sandy, gray $\ldots \ldots$ & 8 & 150 \\
\hline
\end{tabular}

Well D2-3-7aaa

son

Sand and gravel ................

Sandstone, yellow ...........

Shale, blue, gray, pink . .....

Sandstone (water, soft, 5 gpm) --

Shale, gray and pink.........

Sandstone (no water) ............

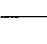

20

$$
\begin{aligned}
& 20 \\
& 38
\end{aligned}
$$

69

80

84

85
Shale, blue, gray, yellow,

brown_.................. $31 \quad 116$

Sandstone, coarse, with shale ... $\quad 9 \quad 125$

Sandstone, dirty ............... $\quad 5 \quad 130$

Sandstone (soft water, $2 \mathrm{gpm}$ ) _. $\quad 8 \quad 138$

Shale, sandy, gray............. $\quad 2 \quad 140$

\section{Well D2-3-7aab}

Soil, sandy_............... 17

Sand and gravel (water) ....... 23

Shale, sandy, blue, pink, gray,

yellow

Sandstone (good water, 1ㅅ́

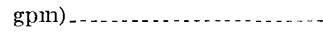

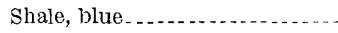

Sandstone, silty, coarse........

Shale, variegated.
Sandstone, coarse (water. 1

gpm)

Shale, variegated ............ $\quad 20 \quad 318$

Sandrock, gray (water, $1 \mathrm{gpm}$ )__ $\quad 9 \quad 327$

Shale, sandy, gray ............. $43 \quad 370$

Shale, blue and brown........ 44

Shale, sandy, sticky, gray ..... $\quad 23 \quad 397$

Sand, white (water, $3 \mathrm{gpm}$ ) _.... $\quad 7 \quad 404$

Shale, sandy, gray........... 4408 
TABLE 5.-Logs of test holes and test wells

[Altitudes given in table of well records (table 3)]

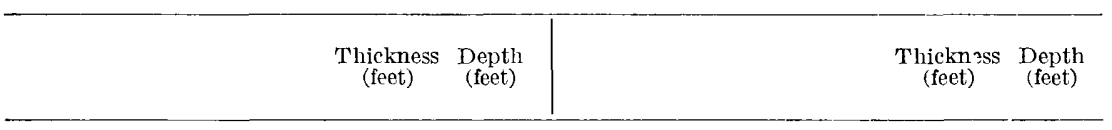

\section{A1-1-34bcb}

\section{Alluvium:}

Clay and silt, dark-brown to black . . . ............

Sand and gravel; mostly coarse sand to fine gravel:

\begin{tabular}{|c|c|c|}
\hline $\begin{array}{l}\text { Alluvium-Continued } \\
\text { some finer sand and } \\
\text { coarser gravel............ }\end{array}$ & 22 & 28 \\
\hline Cody Shale: & & \\
\hline Shale, dark-gray & 3 & 31 \\
\hline
\end{tabular}

A1-2-6aaa

Slope wash and alluvium:

Clay, silt, and sand, tan; very fine to coarse sand and some very fine gravel.

Gravel and sand 6

Wind River Formation:

Conglomerate and very coarse sandstone, loosely cemented (takes drilling mud, no returns) . ........ 6

\section{A1-2-6adb}

Slope wash:

Sand and silt, clayey; some very fine gravel; brown...

Sand, very fine, and silt, tan

Wind River Formation:

Siltstone, dark-gray - . ......

Sandstone, very fine grained to medium-grained, slightly silty, light-brown, fairly well sorted, loosely cemented ....................

Siltstone, dark-greenishgray .....................

Sandstone, very fine grained to medium-grained, lightbluish-gray, loosely cemented

Siltstone, dark-gray -.......

Sandstone, very fine grained to fine-grained, light-bluish-gray, ce-

mented..................

Siltstone, dark-gray ..........

Sandstone, very fine grained to mediumgrained, light-bluishgray, loosely cemented.... Siltstone, dark-brownishgray, and dark-brown medium- to coarsegrained sandstone, loosely cemented; interbedded
Wind River Formation-Con.

Sandstone, mediumgrained to very coarse grained, dark-brown, loosely cemented; thin interbeds of siltstone.....

Siltstone, dark-gray ...-..... Sandstone, coarse-grained 81 to ver y coarse grained, very well sorted, lightgray, loosely cemented, clean (damp) ..............

Sandstone, very coarse grained, to very fine grained conglomerate; very well sorted, lightgray, loosely cemented (damp, water at $101 \mathrm{ft}$ )...

Siltstone(?), poor samples...

Conglomerate, very fine grained, and very coarse grained sandstone; wellsorted, loosely cemented (water, specific conductance 1,200 micromlios) . . . . . . . . . . .

Sandstone, very fine grained, tan, and green and gray siltstone; interbedded............ .

Sandstone, very fine grained to coarse-grained, poorly sorted, tan, loosely cemented. 
TABLE 5.-Logs of test holes and test wells-Continued

\begin{tabular}{ll|l|l}
\hline & $\begin{array}{c}\text { Thickness } \\
\text { (feet) }\end{array}$ & $\begin{array}{c}\text { Depth } \\
\text { (feet) }\end{array}$ & $\begin{array}{c}\text { Thickness } \\
\text { (feet) }\end{array}$ \\
\hline
\end{tabular}

\section{A1-2-21bbb}

Slope wash and alluvium (not mapped):

Sand and silt, brown.......

Gravel, very fine, and

brown sand..............

Wind River Formation:

Siltstone, greenish-gray .....

Marlstone(?), grayish-white, very hard; powdery

returns. ..................

Siltstone, $\tan . . . . . . . . . . . . .$.

Siltstone, very fine grained sandy, greenish-gray . . ...

Siltstone, purplish-gray and olive

Siltstone, bluish-gray .......

Sandstone, very fine grained to medium-grained, bluish-gray (damp) ..........

Siltstone, very fine grained, sandy, bluish-gray . .......

Sandstone, very fine grained to medium-grained, silty, bluish-gray ................

Siltstone, very fine grained, sandy, bluish-gray; hard streaks at 84,88 , and $91 \mathrm{ft}$.

Sandstone, very fine grained, silty, bluish-gray (damp) .

Sandstone, very fine grained to medium-grained, blu-

ish-gray - ..................

Siltstone, very fine grained,

sandy, bluish-gray . ......

Sandstone, very fine grained to medium-grained, bluish-gray and gray (dry) -.-
Wind River Formation-Con

Sandstone, medium- to coarse-grained, light-gray, clean (dry) . ..............

Siltstone, sandy, and very fine grained to mediumgrained sandstone; bluishgray and gray; some coarser sand.

Sandstone, very fine grained to medium-grained, silty, gray; some coarser sand..

Sandstone, coar se-grained to very coarse grained, well-sorted, light-gray, clean (dry) ..............

Sandstone, mediumgrained to very coarse grained, silty, gray (dry).

Sandstone, very fine grained to coarse grained, silty, gray (dry) _ $\quad 15 \quad 255$

Siltstone, sandy, brown_... $\quad 5 \quad 5 \quad 260$

Sandstone, very fine grained to coarse-grained, silty, gray (water) .......

Sandstone and very fine conglomerate; poor samples (water, noticeable increase in water 280-285 $\mathrm{ft}$; specific conductance 730 micromhos) _... _.... $\quad 27 \quad 297$ Siltstone, sandy, gray ..... $\quad 3 \quad 300$ 
TABLE 5.-Logs of test holes and test wells-Continued

\begin{tabular}{c|ccc}
\hline Thickness & Depth \\
(feet) & Thickness & $\begin{array}{c}\text { Depth } \\
\text { (feet) }\end{array}$ \\
\hline
\end{tabular}

\section{A1-2-26cbb}

Slope wash (not mapped):

Sand, silty, clayey, brown.

Wind River Formation:

Sandstone, medium to very coarse grained; mostly fair sorting; tan and yellow; rusty zones; loosely cemented; thin streak of very fine grained and fine-grained conglomerate

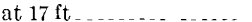

Siltstome, very fine grained, sandy, green . . ........

Sandstone, very fine grained to coarse-grained, green, poorly sorted;

green siltstone ........ .

Sandstone, mediumgrained, yellow, wellsort d . . . . . . . . . .

Siltstone, very fine grained, sandy, green . ...........

Sandstone, very fine grained to medium-grained, bluish-gray, poorly sorted; few hard streaks. .

Sandstone, mostly fine- to medium-grained, bluishgray; fair sorting.......... Siltstone, very fine grained, sandy, dark-gray .........

Sandstone, mostly fine- to medium-grained, bluishgray; fair sorting .......... Siltstone, dark-gray, and bluish-gray very fine grained sandstone. .......

Siltstone, dark-gray ........

Marlstone(?), grayish-white, vary hard; powdery

returns...................

Wind River Formation-Con.

Siltstone, sandy, and very fine-grained silty sandstone; dark-gray (slightly damp about $205 \mathrm{ft}$ ).......

Siltstone or shale, darkreddish-brown $\ldots \ldots . . . . .10 \quad 10 \quad 220$

Siltstone, very fine grained sandy, greenish-gray ...... $\quad 5 \quad 225$

Siltstone, dark-gray ........

Marlstone(?), grayish-white, very hard; powdery returns............... 2

Sandstone, very fine grained to medium-grained, silty, light-gray .............. 340

Siltstone, dark-gray........

Siltstone and silty very fine grained to fine-grained sandstone, dark-brownishgray

Sandstone, medium- to coarse-grained; some finer sand and silt; fair sorting; dark brownish gray ........

Sandstone, very fine grained to medium grained; some coarse sand and silt; dark brownish gray ...........

Siltstone, dark-gray; some sandy siltstone. . . . . . . . . .

Sandstone, coarse-grained to fine-grained conglonerate (water, specific conductance 750 micromhos)

\section{A1-5-15aab}

Shope wash and alluvium:

Silt and very fine sand, tan

Clay, silty, sand, tan .......

Sand, very fine and fine, and clay, $\tan ($ damp) . ..

Sand, mostly fine, tan (wet) _ ...... ....... Sand, mostly coarse, and clay, tan (wet)
Slope wash and alluvium--Con.

Sand, mostly coarse; fair sorting; tan (water increased at $42 \mathrm{ft}$ ) ...

Wind River Formation:

Sandstone, fine- to mediumgrained, bluish-gray .... 
TABLE 5.-Logs of test holes and test wells-Continued

\begin{tabular}{cc|c}
\hline Thickness & Depth \\
(feet) &
\end{tabular}

\section{A2-1-27bcb}

Wind River Formation:

Sandstone, coarse-grained, and very fine grained conglomerate; yellow,

clean . . . . . . . . . . . . . .

Siltstone, very fine grained,

sandy, bluish-gray.

Sandstone, medium grained to very coarse grained; some fine sand and very fine gravel; yellow....................

Sandstone, very fine to very coarse grained, yellow and rusty-brown..

Sandstone, very fine grained to coarse-grained. very silty; sandy siltstone; bluish-gray ... . . .

Sandstone, fine to very coarse grained, yellow and very light brown....

Siltstone, sandy, bluishgray ...................

Sandstone, very fine to very coarse grained, bluish-gray (damp at $92 \mathrm{ft}$ )

Sandstone, mediumgrained to very coarse grained, well-sorted, bluish-gray
Wind River Formation-Con.

Sandstone, very fine to

medium, bluish-gray ..... 7

Siltstone, dark-brownishred................. 8

Sandstone, fine to very coarse grained, bluish-

gray . .................

Siltstone, dark-brownishred, partly sandy ......... . Sandstone, mostly very fine to fine-grained, silty; sandy siltstone; brown and gray (little water 150 to $170 \mathrm{ft}$ )..............

Sandstone, very fine grained to mediungrained, silty; some sandy siltstone; hard (little water at $210 \mathrm{ft}$ ) .....

Sandstone, very fine to very coarse grained, silty, gray and lightgray, partly hard; poor samples (little water 255 to $329 \mathrm{ft}$ )

Sandstone; no sample, no circulation with water or air, probably well-sorted permeable sandstone (water) ................ 3

\section{A2-2-32cbc}

\section{Alluvium:}

Clay or silt, sandy, tan....

Sand, mostly very fine; clay and silt; dark brown

Sand and gravel; mostly coarse sand to fine gravel; mostly dark-colored grains......................

Sand, very fine to coarse; mostly dark-colored grains
4
Sand and gravel; some cobbles or boulders; mostly medium sand to very fine gravel in samples; mostly dark-colored grains; better sorting $26-$ $30 \mathrm{ft}$. 10 Wind River Formation:

Sandstone, very fine grained, silty, dark-olivegreen................... 33 Siltstone, light-bluisl-gray - $\quad 3 \quad 36$ 
TABLE 5.-Logs of test holes and test wells--Continued

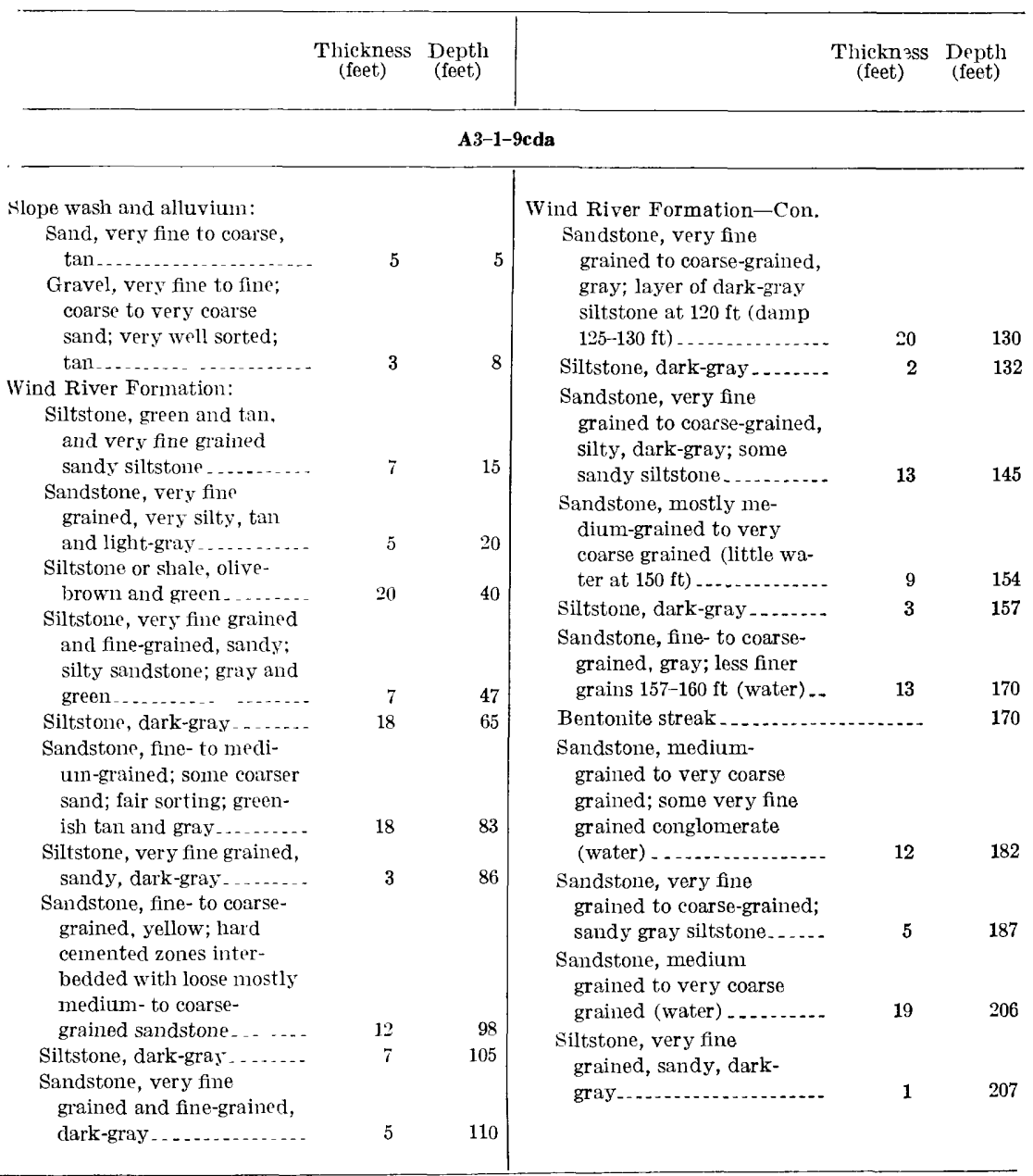

\section{A4-1-11bbd}

Duue(?) sand or alluvium

(not mapped):

Sand, very fine to coarse, silty; contains a little gravel, poorly sorted; tan

Wind River Formation:

Sandstone, very fine grained to coarse-grained, very silty; some sandy siltstone; poorly sorted, greenish-tan..............

Sandstone, mostly fineto coarse-grained; fair sorting; $\tan$
Wind River Formation-Con. Siltstone or shale, greenishgray ......................

Siltstone or shale, darkreddish-brown, green, and dark-gray .............

Sandstone, very fine grained to medium. grained, silty, gray (damp) .....................

Sandstone, very fine grained to fine-grained, well-cemented, lightwhitish-gray, very hard..
30

.


TABLE 5.-Logs of test holcs and test wells-Continued

\begin{tabular}{|c|c|c|c|c|c|}
\hline & \multicolumn{2}{|c|}{$\underset{\text { (feet) }}{\text { Thickness }} \underset{\text { (feet) }}{\text { Depth }}$} & & $\begin{array}{c}\text { Thickness } \\
\text { (feet) }\end{array}$ & $\begin{array}{l}\text { Depth } \\
\text { (feet) }\end{array}$ \\
\hline \multicolumn{6}{|c|}{ A4-1-11bbd-Continued } \\
\hline 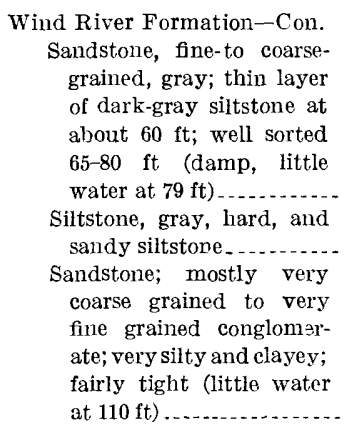 & - & 110 & $\begin{array}{l}\text { Wind River Formation-Con. } \\
\text { Sandstone, very fine } \\
\text { grained to medium- } \\
\text { grained, very silty; very } \\
\text { fine grained sandy silt- } \\
\text { stone; gray . } \\
\text { Sandstone, very fine } \\
\text { grained to medium- } \\
\text { grained gray; stringers of } \\
\text { very coarse grained sand- } \\
\text { stone containing fine } \\
\text { gravel; streaks of light- } \\
\text { gray shale (probably a } \\
\text { little water) } \\
\text { Shale, dark-............. }\end{array}$ & $\begin{array}{l}25 \\
10\end{array}$ & $\begin{array}{l}175 \\
185\end{array}$ \\
\hline
\end{tabular}

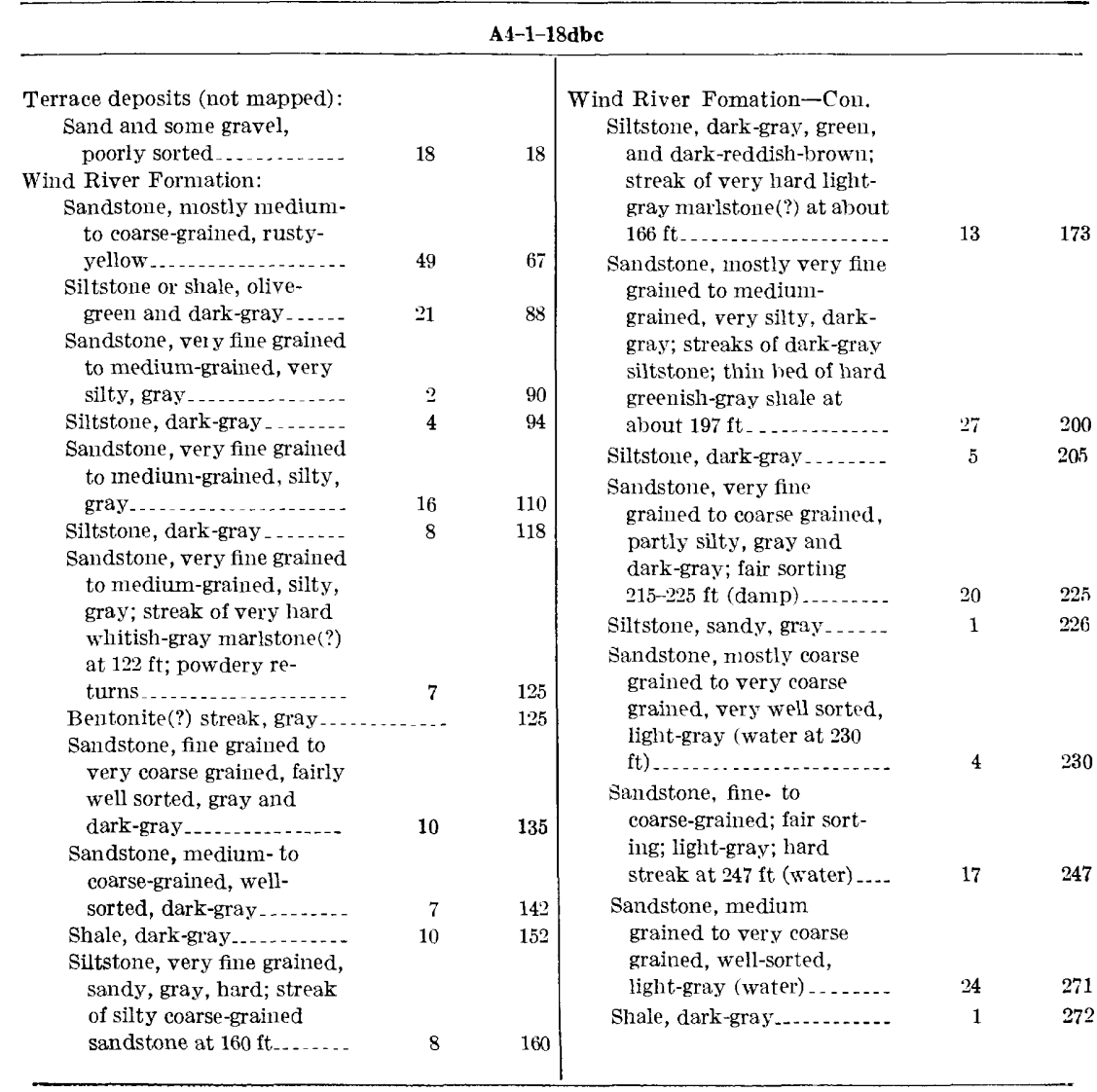


TABLE 5.-Logs of test holes and test wclls-Continued

\begin{tabular}{c|cc} 
Thickness & $\begin{array}{c}\text { Depth } \\
\text { (feet) }\end{array}$ & $\begin{array}{c}\text { Thickness } \\
\text { (feet) }\end{array}$ \\
\hline
\end{tabular}

\section{A5-3-32bcb}

Wind River Formation:

Siltstone, dark-gray and

green; contains some

very fine grained sand ...

Siltstone, very fine

grained, sandy; silty

very fine to fine-grained

sandstone; gray; streak

of very hard white ma-

terial at $40 \mathrm{ft} \ldots . . . . . . . .$.

Siltstone or shale, dark-

reddish-brown_.........

Siltstone, and very fine

grained silty sandstone,

gray

Siltstone, dark-brown and

green.....................

Sandstone, very fine-grained to fine-grained, silty; sandy siltstone; gray .............

Sandstone, fine- to mediumgrained, silty; fair short-

ing; gray ................

Siltstone, dark-gray .........

Siltstone, dark-brown and

greell....................

Siltstone, very fine grained, sandy, dark-gray and

green, hard ...............

Siltstone or shale, dark-

reddish-brown, green, and

dark-gray

Wind River Formation-Con.

Siltstone, very sandy, and

silty; very fine grained to

fine-grained sandstone;

gray ...................

Siltstone, dark-gray; some

very fine grained sandy

siltstone.

Sandstone, very fine

grained, very silty, gray

and light-gray .............

Siltstone, reddish-brown....

Sandstone, very fine grained to medium-grained, silty;

poor sorting; gray

Siltstone, dark-gray and

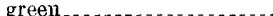

Sandstone, very fine

grained to medium-

grained, silty, gray; some

coarse sand and less silt

180-187 ft

Siltstone, dark-gray; some

gray very fiue grained

sandy siltstone...........

Sandstone, very fine grained to medium-grained, very silty, gray and dark-

brown...................

Siltstone, dark-gray ........

Sandstone, very fine grained and fine-grained, very

silty, gray ................

Sandstone, very fine

grained to coarse-grained,

gray
Siltstone, very fine

grained, saudy, gray and

dark-gray ...............

Siltstone, dark-reddish-

brown, dark-gray, and

green.....................

Siltstone, very fine

grained, sandy, and very

silty; very fine grained

sandstone; light-gray

and gray ..............

Siltstone or shale, dark-

reddisly-brown, green,

and dark-gray; some

very fine grained sandy

siltstone.................

Siltstone, very fine

grained, sandy; silty

sandstone; gray .......... .

Siltstone or shale, dark-

reddish-brown, green

and dark-gray ............

Siltstone, sandy, light-gray

very hard . ...............

Limestone, very hard (or

very fine grained cal-

careous well-cemented

sandstone), mostly gray,

some tan; some cherty(?)

material of other colors.

Siltstone or shale, dark-

reddish-brown, green,

and dark-gray...........

Siltstone, very fine grained, sandy, gray and lightgray; streak of reddishbrown shale at $368 \mathrm{ft}$......

Siltstone, dark-gray; some

brown .................

Siltstone, very fine grained, sandy, light-gray.........
Sandstone, very fine

grained to fine-grained,

silty, light-gray 
TABLE 5.-Logs of test holes and test wells-Continued

$\begin{array}{cc}\text { Thickness } \\ \text { (feet) }\end{array} \quad \begin{gathered}\text { Depth } \\ \text { (feet) }\end{gathered} \mid \quad \begin{gathered}\text { Thickness Depth } \\ \text { (feet) }\end{gathered}$

A5-3-32bcb-Continued

Wind River Formation-Con.

Siltstone or shale, dark-

reddish-brown, green,

and dark-gray; some

gray very fine grained

sandy siltstone below

$395 \mathrm{ft}$....................

Siltstone or shale, dark-

reddish-brown, green,

and dark-gray; thin beds

of gray very fine grained

sandy siltstone and silty

sandstone at about 432 ,

448,469 , and $482 \mathrm{ft}$

Sandstone, very fine

grained to medium-

grained, slightly silty;

fair sorting; light-gray ... .

Siltstone or shale, dark-

reddish-brown, green,

and dark-gray; hard

streak at $512 \mathrm{ft}$
41

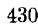

60

$4 ! 90$

$4 ! 5$

20
Wind River Formation-Con.

Sandstone, very fine to

fine-grained, silty, light-

gray
Siltstone or shale, dark-

reddish-brown; some

green

Sandstone, very fine

grained to medium-

grained, silty, light-gray,

Siltstone or shale, dark-

reddish-brown; some

green..................

Siltstone, very fine grained, sandy, light-gray, hard...

Siltstone or shale, dark-

reddish-browu; some

green (dry hole to total

depth)

\section{A5-1-21ced}

Terrace deposits:

Gravel and sand, angular

fragments, silty, poorly

sorted ....................

Wind River Formation:

Sandstone, very fine grained to fine-grained, silty, fairly well sorted, olive-tan, soft, loosely cemented

Siltstone, black, rustybrown, and green........

Siltstone, green, few streaks of green; rusty very fine grained silty sandstone ................

Sandstone, very fine grained and fine-grained, rusty, olive-tan...........

Marlstone(?), white, very hard....................

Siltstone, gray and green: contains very fine sand...

Sandstone, very fine grained to mediumgrained, olive-tan .......

Siltstone, bluish-gray and green; layers of very fine grained silty sandstone. - hard......................
Wind River Formation-Con. Sandstone, fine- to medium-grained, wellsorted, blue-gray; streak of very hard white

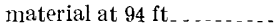

Siltstone or shale, dark-

gray and dark-reddish-

brown.................

Siltstone or shale, darkgray; streaks of lightgray very fine grained to fine-grained silty sandstone at 120,140 , and $150 \mathrm{ft}$.

Sandstone, very fine grained to mediumgrained, silty, gray; coarser and better sorted $160-165 \mathrm{ft}$. sandy; some silty sandstone; gray .............. 12

Marlstone(?), white, very hard; powdery returns....

Siltstone, dark-gray .......

Sandstone, very fine grained to fine-grained,$$
\text { silty, gray ............... }
$$

Siltstone, very fine grained, 
TABLE 5.-Logs of test holes and test wells--Continued

\begin{tabular}{|c|c|c|c|c|c|}
\hline & $\begin{array}{c}\text { Thickness } \\
\text { (feet) }\end{array}$ & $\begin{array}{l}\text { Depth } \\
\text { (feet) }\end{array}$ & & $\begin{array}{c}\text { Thickness } \\
\text { (feet) }\end{array}$ & $\begin{array}{c}\text { Depth } \\
\text { (feet) }\end{array}$ \\
\hline \multicolumn{6}{|c|}{ A5-1-21ced } \\
\hline $\begin{array}{l}\text { Wind River Formation-Con. } \\
\text { Siltstone, dark-gray } \\
\text { Sandstone, very fine } \\
\text { grained to fine-grained, } \\
\text { silty, gray -........... } \\
\text { Siltstone, dark-gray } \\
\text { Sandstone, very fine } \\
\text { grained to medium- } \\
\text { grained, gray } \\
\text { Sandstone, nedium- } \\
\text { grained, very well sorted, } \\
\text { gray; hard streak at } 266 \\
\text { ft (damp) }\end{array}$ & - & $\begin{array}{l}245 \\
250 \\
255\end{array}$ & 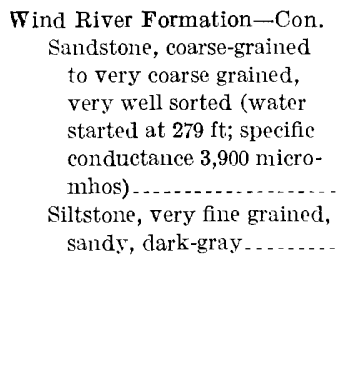 & $\begin{array}{l}\text { 2) } \\
1\end{array}$ & $\begin{array}{l}295 \\
296\end{array}$ \\
\hline
\end{tabular}

\section{A5-5-33aba}

\section{Terrace deposits:}

Gravel, sand, and clay, poorly sorted; gravel is angular and largely of sedimentary rocks.

Wind River Formation:

Siltstone, very fine grained, sandy; silty very fine to medium-grained sandstone; green.............

Siltstone, green and olive

Sandstone, very fine grained, light-gray and green; hard cemented streaks.

Sandstone, fine to coarsegrained, very well sorted, light-gray and green (damp) .................

Siltstone or shale, darkgray

Sandstone, very fine grained, silty, dark-gray; dark-gray and green sandy siltstone .........

Siltstone or shale, darkgray and green.......... 7 Sandstone, very fine grained to mediungrained, silty, gray
Wind River Formation-Con.

Siltstone, dark-gray and green, partly sandy

Siltstone, sandy, and very

fine to fine-grained silty

sandstone; gray . . . . . . 8

Sandstone, very fine grained to mediumgrained; fair sorting; dark-gray (dry) .........

Siltstone, dark-gray, streak of very fine to finegrained silty sandstone at $150 \mathrm{ft}$..................

Sandstone, very fine to fine-grained; siltstone; dark-gray; streaks of hard white material . . . . . $\quad 7 \quad 167$ Siltstone, dark-gray_....... $\quad 4 \quad 171$

Maristone(?), white, very liard................. $2 \quad 173$

Sandstone, fine to mediumgrained, well-sorted, gray (water at $182 \mathrm{ft}$ ) . . . . $\quad 13 \quad 186$ Shale, dark-gray, oil stain _ $\quad 1 \quad 187$ Sandstone, very fine grained, silty, gray $\ldots . . . . \quad 188$ Shale, very dark gray. . . . $\quad 2 \quad 1 \%$ 
TABLE 5.-Logs of test holes and test wells--Continued

\begin{tabular}{|c|c|c|c|c|c|}
\hline & $\begin{array}{c}\text { Thickness } \\
\text { (feet) }\end{array}$ & $\begin{array}{c}\text { Depth } \\
\text { (feet) }\end{array}$ & & $\begin{array}{c}\text { Thickness } \\
\text { (feet) }\end{array}$ & $\begin{array}{l}\text { Depth } \\
\text { (feet) }\end{array}$ \\
\hline \multicolumn{6}{|c|}{ B $4-1-4 c b b$} \\
\hline 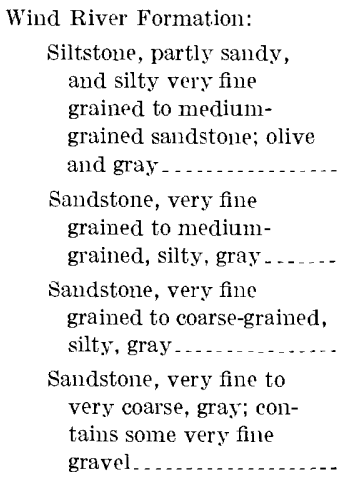 & $\begin{array}{l}- \\
\\
- \\
- \\
-\end{array}$ & 115 & 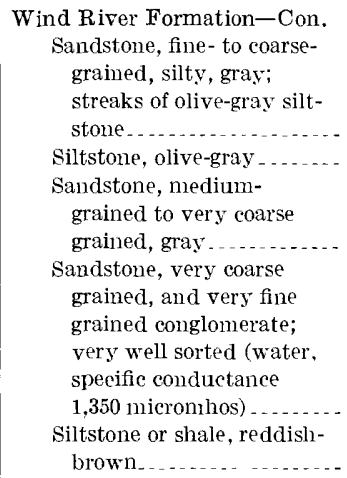 & . & $\begin{array}{l}135 \\
140\end{array}$ \\
\hline
\end{tabular}

B4-2-6add

Wind River Formation:

Siltstone, sandy, and very

fine grained silty sand-

stone; light-gray - .

Sandstone, fine- to coarse-

grained; fair sorting; tan

and light-gray; mostly

firmly cemented.

37

Sandstone, very fine

grained to fine-grained,

silty, tan, loosely

cemented...............

Sandstone, medium- to

coarse-grained, well-

sorted, tan, loosely

cemented.

Maristone(?), very light

gray, very hard.

Sandstone, coarse-grained and very coarse grained; very fine grained con-

glomerate

Sandstone, mediunl- to coarse-grained, cemented, very hard. . . . . . . . . . ....

Conglomerate, mostly very fine to fine gravel.........

Siltstone, green and tan....

Marlstone(?), light-gray, very hard.............

Conglonerate, mostly very fine to fine gravel, lightgray and tan
Wind River Formation-Con. Sandstone, fine- to coarsegrained; fair sorting; gray; some very coarse sand 115-120 ft............. Siltstone, sandy, dark-gray -

Conglomerate, very fine grained, and very coarse sand, very well sorted, gray (still dry) ........... Sandstone, mostly coarsegrained to very coarse grained, well-sorted, gray (wet at $136 \mathrm{ft}$ ) ............

Siltstone, sandy, gray...... Sandstone, mostly mediun- to coarsegrained; fair sorting; gray (dry) ..............

Sandstone, mostly very fine grained to mediumgrained, well-sorted, gray Siltstone, gray, partly sandy, very fine grained. Sandstone, very fine graine 1 to medium-grained, silty, light-gray _...... . . . . . . . . 13

Siltstone, reddish-brown.... Sandstone, very fine graine 1 to fine-grained, silty, light-gray _.............. $\quad 18$ 120

Siltstone, red and green, and some very fine grained silty sandstone...
135 
T.1BLE .5.-Logs of test holes and test wells-Continued

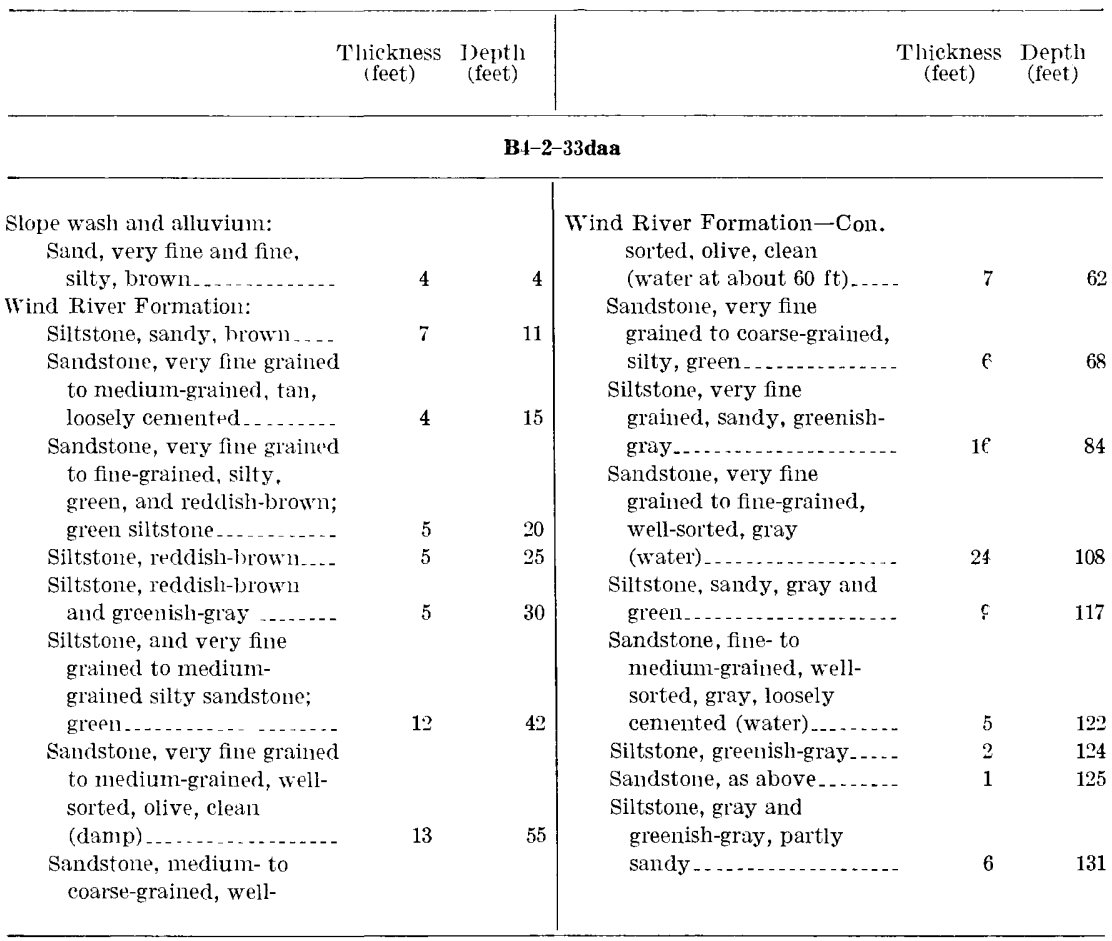

\section{B1-1-2cda}

[Log of test hole $50 \mathrm{ft}$ west of well]

Alluvium:

Clay and silt, dark-brown and tan................ 6

Sand and gravel; some cobbles. ...............

Sand, gravel, and cobbles; some boulders
Alluvium-Con.

Sand and gravel $\ldots \ldots \ldots$. 40

Clay

Gravel. ............... 34

Wind River Formation:

Siltstone, gray _...

Sandstone............... $\quad 117$

\section{B1-4-22aba}

Terrace deposits:

Soil, dark-brown, sandy, gravelly _........ 1

Sand and silt, clayey, gravelly, tan ......... 7

Sand, gravel, and cobbles... 12

Sand and gravel.
Terrace deposits--Con.

Sand, gravel, and cobbles; some boulders......... $\quad \varepsilon \quad 35$

Wind River Formation: Siltstone or shale, reddishlrown_...........

$2 \quad 37$


TABLE 5.-Logs of test holes and test wells-Continued

\begin{tabular}{c|cc}
\hline $\begin{array}{c}\text { Thickness } \\
\text { (feet) }\end{array}$ & $\begin{array}{c}\text { Depth } \\
\text { (feet) }\end{array}$ & $\begin{array}{c}\text { Phickness } \\
\text { (feet) }\end{array}$ \\
\hline
\end{tabular}

\section{B4-1-26abb}

Terrace deposits:

Cobbles, gravel, and sand, clayey, soily, brown.....

Cobbles, gravel, and sand; poorly cemented with white calcareous cement .

Cobbles, gravel, and coarse sand, angular; boulder at $8 \mathrm{ft}$......................

Sand and fine gravel; some coarser rock

Sand, clay, and fine gravel; some coarser rock; rustyyellow water.
1

3

Terrace deposits-Con.

Sand and fine gravel; some

coarser gravel_............ 10

26

Sand, very fine to coarse; streaks of brown clay.....

Sand and fine gravel; streaks of brown clay and coarser gravel.

d River Formation:

Siltstone, and very fine grained sandstone; blue gray; poor samples........ Siltstone(?), red; water color changed to reddish-orange; no samples.

B5-3-32dda

Slope wash and alluvium:

Gravel veneer on surface.

Silt, sandy, clayey, brown..

Wind River Formation:

Siltstone, greenish-gray . . . . .

Siltstone, reddish-brown

and greenish-gray.

Siltstone, very fine grained, sandy, greenish-gray and brownish-gray (wet at $35 \mathrm{ft}$ ) . . ..................

Sandstone, very fine grained, silty, greenishgray (little water) .........

Sandstone, mostly very fine grained to fine-
Wind River Formation-Con. grained, silty; siltstone; greenish-gray and reddish-brown (water) .... 15

siltstone, greenish-gray and light-purple ...... -

Sandstone and siltstone, gray and light-purple (water from $70-75 \mathrm{ft}$ ) ..... Sandstone, fine- to medium-grained, wellsorted, balck and white grains, clean (water) Siltstone, gray

\section{B5-1-10abc}

\section{Alluvium:}

Sand, clayey, poorly sorted. brown .... .

Wind River Formation:

Siltstone, dark-greenishgray, light-gray, and very light maroon

Siltstone, and some very fine grained silty sandstone; greenish-gray _.....

Sandstone, mostly very fine grained to niediumgrained, greenish-gray . . . .
Wind River Formation-Con. Siltstone, red; some green; some greenish-gray very fine grained silty sandstone $45-50 \mathrm{ft}$. . . . . . . . . . . Siltstone, red .............

Siltstone, greenish-gray and dark-gray; some very fine grained silty sandstone . . Sandstone, very fine grained to medium-grained, greenish-gray; very hard material at $92 \mathrm{ft}$ (water at 83 ft) 
TABLE 5.-Logs of test holes and test wells-Continued

\begin{tabular}{ll|l}
\hline Thickness & $\begin{array}{c}\text { Depth } \\
\text { (feet) }\end{array}$ & $\begin{array}{c}\text { Thickness Depth } \\
\text { (feet) }\end{array}$ \\
\hline
\end{tabular}

\section{B5-4-17bdd}

\section{Wind River Formation:}

Sandstone, very fine grained to medium-grained, very silty, light-gray; layer of reddish-hrown sandy siltstone at $10 \mathrm{ft}$

Conglomerate, very fine grained; contains coarse to very coarse sand...... .

Siltstone, red, dark-gray, and brown . ..............

Sandstone, silty, light-red

Conglomerate, very fine grained; contains sand...

Siltstone, reddish-brown and gray, partly sandy

Conglomerate, very fine grained; contains sand..

Siltstone, gray and brown, partly sandy

Marlstone(?), light-gray, calcareous, very hard .... .

Siltstone, dark-reddishbrown ...................

Siltstone, dark-gray . . ......

Sandstone, very fine to very coarse grained, silty .....

Siltstone, sandy, light-gray -

Sandstone, very fine grained, very silty, light-brown ...

Siltstone, dark-reddishbrown

Sandstone, mostly very fine to medium-grained, silty

Sandstone, coarse-grained to very coarse grained, well-sorted, loosely cemented (wet at $150 \mathrm{ft}$ ) . .
Wind River Formation-Con.

Siltstone, sandy, lightgray; poor samples....... 10

Marlstone(?), light-gray, very hard; poor samples.

Siltstone, and silty sandstone(?), red; liard drilling 170-180, 185-195, 210217; poor samples (possibly a little water 185-210ft) . . . . . . . . . .

[Began drilling with water instead of air]

Siltstone or shale, red and green

Siltstone, red, green, and purple.................

Sandstone, fine- to conrsegrained in white clay matrix.............

Siltstone, red, green, and purple; white clayey sandstone (as above) .... 5

Marlstone(?), light-gray, very hard . . . . . . . . . . . .

Siltstone, red and green; some returns of soft lightgray sandy clay .........

Siltstone, red and green, sandy, soft..............

Siltstone, sandy, and very fine to coarse-grained silty sandstone; green, gray, and white..........

Siltstone, sandy, red, and green....................

Sandstone, silty, green and white, partly clayey; red siltstone; streaks of very hard material $312-31 i \mathrm{ft} . .$.

\section{B6-3-33ccd}

Wind River Formation:

Siltstone, dark-reddishbrown and grayish green..

Sandstone, very fine grained to coarse-grained, very silty, very poorly sorted, reddish-brown
Wind River Formation-Con.

Siltstone, dark-reddishbrown and brick-red, partly sandy

Siltstone, light-gray,

greenish-gray; some

brown. 
T.ıBLE 5.-Logs of test holes and test wells-Continued

\begin{tabular}{l|ll}
\hline & $\begin{array}{c}\text { Thickness } \\
\text { (feet) }\end{array}$ & $\begin{array}{c}\text { 1)epth } \\
\text { (feet) }\end{array}$ \\
\hline
\end{tabular}

B6-4-36cdb

Aycross and Wind River

Formations:

Sandstone, fine- to coarse-

grained, green and greenish-tan; hard cemented layers and streaks of very fine grained and fine-grained conglomerate...........

Sandstone, fine- to coarsegrained, blue-gray and olive-brown; streak of green siltstone at about $40 \mathrm{ft}$.

Siltstone, very fine grained, sandy, dark-green and dark greenish-gray, very hard

Sandstone, medium- to coarse-grained; fair sorting (danip) ...........

Siltstone, dark-gray and greenish-grav............

Sandstone, very fine grained to fine-grained, silty, gray ................

Siltstone, gray ............
Aycross and Wind River

Formation:-Con.

Sandstone, fine- to coarsegrained, very light gray...

Sandstone, coarse-grained to very coarse grained, very light gray . . . . . . . . .

Sandstone, very fine grained to mediumgra!ned, very light gray and brown .............

Siltstone, dark-reddish-

brown -..............

Sandstone, mostly very fine grained to mediumgrained, gray . ............

Siltstone, dark-reddishbrown, and some brown sandstone...............

Sandstone, very fine grained to mediumgrained, gray (trace of water 195-200 ft ) ........ 25

Sandstone, fine- to coarsegrained, gray (damp) siltstone(?); no samples. ...

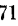

\begin{tabular}{|c|c|c|c|c|}
\hline \multicolumn{5}{|c|}{ C1-1-4dac } \\
\hline $\begin{array}{l}\text { Alluvium: } \\
\text { Soil, sand, gravel, and } \\
\text { coblles............... } \\
\text { Cobbles, gravel, and sand; } \\
\text { contains some tan and } \\
\text { light-brown clay }\end{array}$ & 7 & 8 & $\begin{array}{l}\text { Alluvium-Continued } \\
\text { Cobbles, gravel, sand, and } \\
\text { some boulders; contains } \\
\text { streaks of light-brown } \\
\text { clay..................... } \\
\text { Cody Shale: } \\
\text { Shale, dark-gray; oil odor... }\end{array}$ & 30 \\
\hline
\end{tabular}


TABLE 5.-Logs of test holes and lest wells-Continued

Thickness
(feet) $\begin{gathered}\begin{array}{c}\text { Depth } \\ \text { (feet) }\end{array} \\ \text { Thickness } \\ \text { (feet) }\end{gathered}$

\section{D1-1-14aaa}

Slope wash and alluvium:

Silt, slightly sandy, brown _ $\quad 7$

Gravel and coarse sand..... 3

Gravel, fine to medium,

Slope wash and alluvium--Con.

Gravel, fine to inedium,

and coarse sand......... 3

Cody Shale:

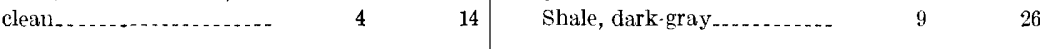

\section{D1-1-16ddd}

Slope wash and alluvium:

Silt, sandy, tan..... 3

Slope wash and alluvium-Con.

\begin{tabular}{ll|ll}
3 & 3 & Gravel, fine to coarse $\ldots \ldots$ & 9
\end{tabular}

Silt, heavy, $\tan \ldots . . . . . . .6$

and coarse sand ........ 7

Sand, fine to coarse......... $\quad 7 \quad 38$

Frontier(?) Formation:

22

shale, dark-gray .......... $\quad 3 \quad 41$

\section{D1-1-21dda}

Slope wash and alluvium:

Clay and sand, brown.....

Clay and sand, mostly very

fine to fine, $\tan . . . . . .$.

Sand and gravel; mostly

very coarse sand to fine

gravel; layers of clay; not

loose, may be lightly

cemented or bound with

clay

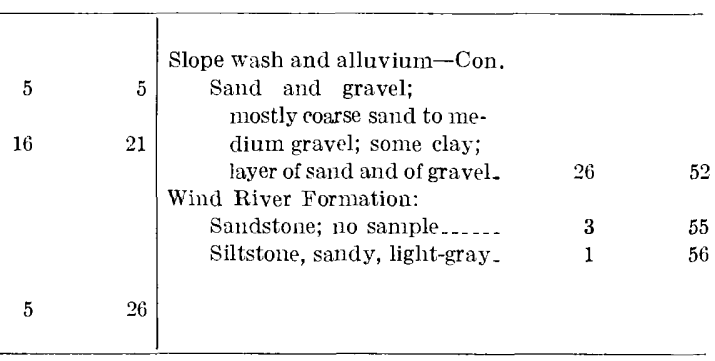

D1-1-22bcb

Slope wash and alluvium:

Clay, silty, yellow-green to

tall; soil at top............

Gravel, sand, and clay.....

Gravel and sand.............

Clay, sandy, brown ........
Cody shale:

Clay(?) and shale, dark-

gray (clay zone may be

preseut above Cody

Shale)............... $\quad 1547$

Shale, dark-gray

\section{D1-1-23ada}

Slope wash and alluvium:

Clay and sand; some very

coarse sand; tan. .........

Clay, sandy; mostly very fine sand; brown to tan..-

Sand and clay; very fine to coarse sand..............

Sand, clayey; mostly

coarse sand.
Slope wash and alluvium-Con.

Gravel and sand; mostly

coarse sand to fine gravel_ $\quad 3 \quad 36$

Clay, sandy, tan $\ldots . . . . . .40$

11

6 Cody shale:

Shale.................... $\quad 1 \quad 41$ 
TABLE 5.-Logs of test holes and test wells-Continued

\begin{tabular}{|c|c|c|c|c|c|}
\hline & $\begin{array}{c}\text { Thickness } \\
\text { (feet) }\end{array}$ & $\begin{array}{l}\text { Depth } \\
\text { (feet) }\end{array}$ & & $\begin{array}{l}\text { Thickness } \\
\text { (feet) }\end{array}$ & $\underset{(\text { fe }: t)}{\text { Depth }}$ \\
\hline & & D1-3- & ded & & \\
\hline 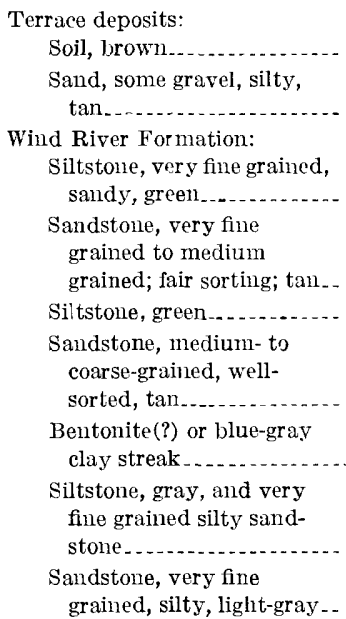 & - & $\begin{array}{l}32 \\
41\end{array}$ & 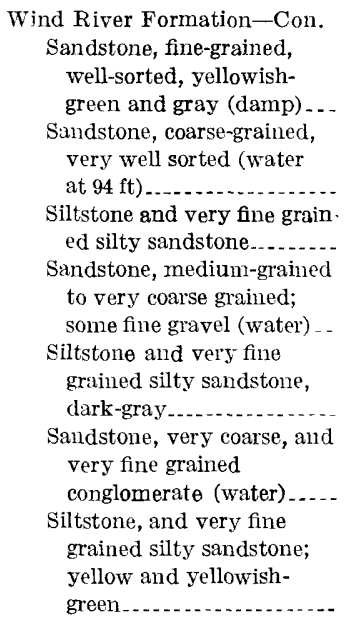 & . & 104 \\
\hline
\end{tabular}

\section{D1-3-29cec}

Slope wash and alluvium

(not mapped):

Silt, sandy, reddish-brown. -

Wind River Formation:

Siltstone, red..............

Sandstone, very fine to very coarse grained, silty, white to tan, loosely

cemented................

Siltstone, very fine grained sandy, purple and dark-

gray

Siltstone, very fine grained sandy, tan and dark-gray

Sandstone, very fine grained to coarse-grained, silty; siltstone; tan, gray, and brown....................

Siltstone, gray, purple, and red...............

Sandstone, fine-grained to very coarse grained; some very fine gravel; fair sorting; tan; loosely cemented; clean ........ . .

Siltstone, very fine grained, sand $y$, rusty and green. ish-gray
Wind River Formation-Con. Sandstone, mediumgrained to very fine grained conglomerate; tan, clean, loosely cemented.

Sandstone, fine-grained to very fine grained conglomerate; tan, loosely cemented...............

Siltstone, sandy, and very fine-grained to mediumgrained silty sandstone; greenish-gray............

Sandstone, very fine grained to coarse-grained, silty, poorly sorted, greenish-gray ...............

4

21
. 
Table 5.-Logs of test holes and test wells-Continued

\section{Thickness Depth} (feet) (feet)

\section{D1-3-29ccc-Continued}

Wind River Formation-Con. Sandstone, fine- to coarsegrained; fair sorting; hluish-gray . ... Sandstone, mediumgrained to very fine grained conglomerate well-sorted; greenishgray to $195 \mathrm{ft}$; tan hellow;
Wind River Formation-Con. poor returns below $150 \mathrm{ft}$; some thin siltstone layers (damp at $150 \mathrm{ft}$, no water noted above $150 \mathrm{ft}$; water at $165 \mathrm{ft}$; specific conductance 2,000 microm hos) . . . Siltstone, very fine grained, sandy, greenish-gray..... .

\section{D1-1-2bca}

Alluvium:

Sand, fine, silty .......... . 4

Sand, fine to nedium.... . 5

Gravel, fine to coarse..... 5
Wind River Formation:

4 Siltstone, gray.......... 2

$2 \quad 16$

\section{D1-4-11bba}

\section{Alluvium:}

Soil and silt, sandy, brown -

Gravel and sand; mostiy coarse sand to medium gravel

\section{D1-1-11cac}

Slope wash (not mapped):

Silt, sandy ..........

Wind River Formation:

Siltstone, gray............. 6

Siltstone, sandy, gray and

brown..................

Siltstone, gray .............

Sandstone, fine-grained, silty.
6

7
Wind River Formation: Sandstone, very fine grained to mediumgrained, tan .......... $\quad 2 \quad 15$ Siltstone, sandy, lightbluish-gray .......... 1
Wind River Formaiton-Con.

Siltstone, gray..... $18 \quad 44$ Siltstone, sandy, gray . . . . $\quad 7 \quad 51$ Siltstone, gray, hard....... $\quad 22 \quad 73$ Siitstone, sandy, gray ..... $22 \quad 75$

Sandstone, fine- to niedium-grained (water) _- $\quad 8 \quad 83$ 
TABLE 5.-Logs of test holes and test wells-Continued

\begin{tabular}{|c|c|c|c|c|c|}
\hline & $\begin{array}{c}\text { Thickness } \\
\text { (feet) }\end{array}$ & $\begin{array}{c}\text { Depth } \\
\text { (feet) }\end{array}$ & & $\begin{array}{c}\text { Thickness } \\
\text { (feet) }\end{array}$ & $\begin{array}{l}\text { Depth } \\
\text { (feet) }\end{array}$ \\
\hline \multicolumn{6}{|c|}{ D1-4-33daa } \\
\hline $\begin{array}{l}\text { Slope wash and alluvium: } \\
\text { Clay and soil. } \\
\text { Sand, mostly medium to } \\
\text { very coarse, clayey; fair } \\
\text { sorting; tan (water) } \\
\text { Sand, as above except more } \\
\text { clay and grayer color } \\
\text { (less water) }\end{array}$ & - & 12 & $\begin{array}{l}\text { Slope wash and alluvium-Cor. } \\
\text { Sand, as above except less } \\
\text { clay and generally } \\
\text { coarser (water) } \\
\text { Wind River Formation: } \\
\text { Siltstone, sandy, gray ....... }\end{array}$ & $\begin{array}{l}3 \\
2\end{array}$ & 27 \\
\hline
\end{tabular}


TabLe 5.-Logs of test holes and test wells-Continued

\begin{tabular}{|c|c|c|c|c|c|}
\hline & $\begin{array}{c}\text { Thickness } \\
\text { (feet) }\end{array}$ & $\underset{\text { Depth }}{\text { (feet) }}$ & & $\begin{array}{c}\text { Thickness } \\
\text { (feet) }\end{array}$ & $\begin{array}{l}\text { Depth } \\
\text { (feet) }\end{array}$ \\
\hline \multicolumn{6}{|c|}{ D1-5-11bdd } \\
\hline $\begin{array}{l}\text { Slope wash and alluvium: } \\
\text { Sand, very fine to medium, } \\
\text { tan; dune sand.......... } \\
\text { Sand and silt, tan } \\
\text { Sand, fine to very coarse; } \\
\text { some fine gravel; poorly } \\
\text { sorted; some coarser } \\
\text { gravel } 22-27 \mathrm{ft} \text { (water at } \\
25 \mathrm{ft} \text { ) }\end{array}$ & - & $\begin{array}{l}12 \\
15\end{array}$ & $\begin{array}{c}\text { Slope wash and alluvium-Con. } \\
\text { Sand, very coarse, fairly } \\
\text { well sorted (water) } \\
\text { Sand, mostly very coarse; } \\
\text { some very fine gravel; } \\
\text { very well sorted; tan } \\
\text { (water) } \\
\text { Wind River Formation: } \\
\text { Siltstone, bluish-gray......... }\end{array}$ & . & $\begin{array}{l}43 \\
63\end{array}$ \\
\hline
\end{tabular}


T.ABLE 6.-Chemical analyses of ground-water

Analytical results in parts per million, except as itdicated.

\begin{tabular}{|c|c|c|c|c|c|c|c|c|c|c|c|c|}
\hline & & & & & & 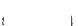 & & & & & & 1 \\
\hline Location & $\begin{array}{c}\text { Deptl } \\
\text { of } \\
\text { well } \\
\text { (feet) }\end{array}$ & $\begin{array}{c}\text { Pro- } \\
\text { duc- } \\
\text { tion } \\
\text { inter- } \\
\text { val } \\
\text { (feet) }\end{array}$ & $\begin{array}{l}\text { Date of } \\
\text { collee- } \\
\text { tion }\end{array}$ & $\begin{array}{l}\text { Tem- } \\
\text { pera- } \\
\text { ture } \\
\left({ }^{\circ} \mathrm{F}\right)\end{array}$ & $\begin{array}{l}\text { Sil- } \\
\text { ita } \\
\text { (si } \\
\text { (1) })\end{array}$ & $\left|\begin{array}{l}\text { Total } \\
\text { iron } \\
(\mathrm{Fe})\end{array}\right|$ & $\begin{array}{l}\text { Cal- } \\
\text { cium } \\
\text { (Ca) }\end{array}$ & $\begin{array}{c}\text { Mag- } \\
\text { nesi- } \\
\text { uml } \\
(\mathrm{Mg})\end{array}$ & $\underset{(\mathrm{Na})}{\text { Sodi- }}$ & $\begin{array}{l}\text { Potas- } \\
\text { sium } \\
(\mathrm{K})\end{array}$ & $\begin{array}{l}\text { Bicar- } \\
\text { bonate } \\
\left(\mathrm{HCO}_{3}\right)\end{array}$ & $\begin{array}{c}\text { Car- } \\
\text { bon- } \\
\text { ate } \\
\left(\mathrm{CO}_{3}\right)\end{array}$ \\
\hline & & & & & & & & & & & & \\
\hline
\end{tabular}

Madison Limestone and Bighorn Dolomite

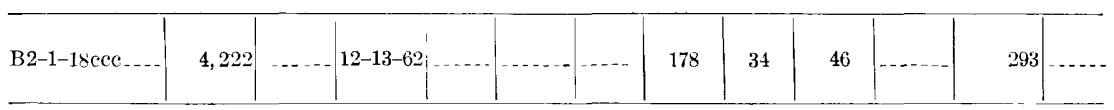

Tensleep Sandstone

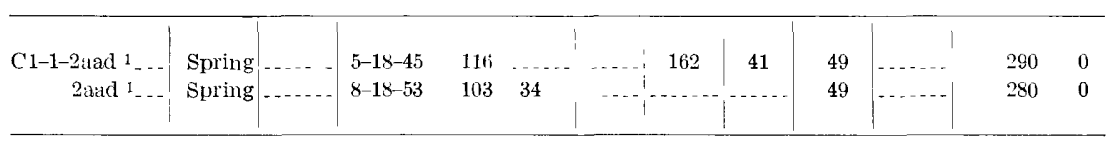

Permian rocks and (or) Dinwoody Formation

\begin{tabular}{rr|rr|r|r|r|r|r|r|r|r|r|r}
\hline B5-6-14dad ... & 980 & At 980, 9-30-64 & 51 & 9.4 & 20.29 & 409 & 68 & 557 & 18 & 734 & 0 \\
35ada_.. & 200 & $75-200$ & $10-1-65$ & 48 & 14 & .44 & 447 & 171 & 469 & 7.6 & 367 & 0 \\
\hline
\end{tabular}

\section{Jurassic, Jurassic(?), and Triassic(?) rocks}

\begin{tabular}{|c|c|c|c|c|c|c|c|c|}
\hline B3-1-5ba_.... & 5,306 & $10-31-55$ & 0.23 & 4,380 & 93 & 4,320 & $379^{\prime}$ & 0 \\
\hline
\end{tabular}

\section{Frontier Formation}

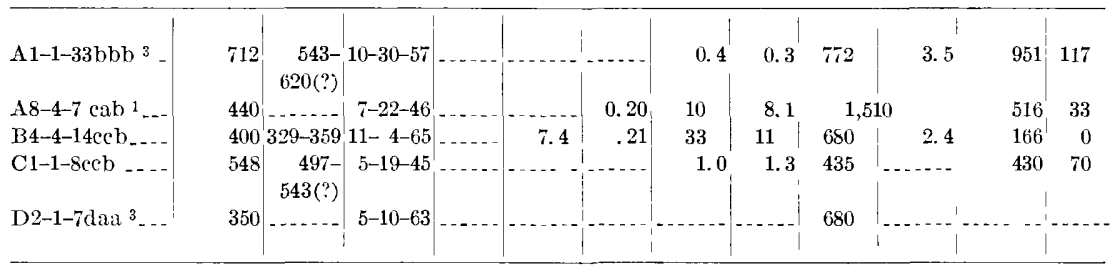

Cody Shale

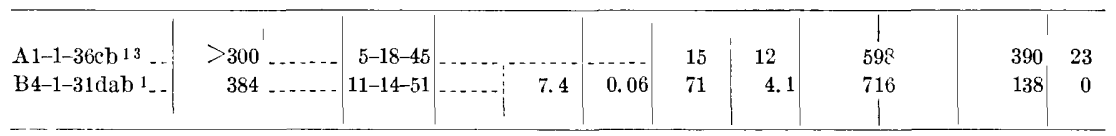

\section{Fort Union Formation}

\begin{tabular}{|c|c|c|c|c|c|c|c|c|c|c|c|}
\hline D1-2-9bbbl _- & 430 & $365-412$ & $211-6-64$ & 6.9 & 0.60 & 8.3 & 1.8 & 387 & 3.1 & 561 & 16 \\
\hline $10 \operatorname{dec}^{3}$ & 473 & $412-418$ & $811-19-66$ & $\ldots$ & - & 6 & 3 & 400 & 3 & 522 & 33 \\
\hline
\end{tabular}

See footnotes at end of table. 
samples, Wind River Indian Reservation, Wyo.

Analyses by U.S. Geological Survey, except as indicated]

\begin{tabular}{|c|c|c|c|c|c|c|c|c|c|c|c|c|}
\hline \multirow{2}{*}{$\begin{array}{l}\text { Sulfate } \\
\left(\mathrm{SO}_{4}\right)\end{array}$} & \multirow{2}{*}{$\begin{array}{l}\text { Clilo- } \\
\text { ride } \\
\text { (C1) }\end{array}$} & \multirow{2}{*}{$\begin{array}{l}\text { Fluo- } \\
\text { ride } \\
(\mathbf{F})\end{array}$} & \multirow{2}{*}{$\begin{array}{c}\mathrm{Ni}- \\
\text { tiate } \\
\left(\mathrm{NO}_{3}\right)\end{array}$} & \multirow{2}{*}{$\begin{array}{l}\text { Bo- } \\
\text { lon } \\
\text { (B) }\end{array}$} & \multicolumn{2}{|c|}{$\begin{array}{l}\text { Dissolved } \\
\text { solids }\end{array}$} & \multicolumn{2}{|c|}{$\begin{array}{l}\text { Hardness } \\
\text { as } \mathrm{CaCO}_{3}\end{array}$} & \multirow{2}{*}{$\begin{array}{l}\text { Sodi- } \\
\text { um-ad- } \\
\text { solp- } \\
\text { tion- } \\
\text { ratio } \\
\text { (SAR) }\end{array}$} & \multirow{2}{*}{$\begin{array}{c}\text { Spe- } \\
\text { cific } \\
\text { con- } \\
\text { duct- } \\
\text { ance } \\
\text { (inicro- } \\
\text { mhos at } \\
25^{\circ} \mathrm{C} \text { ) }\end{array}$} & \multirow[b]{2}{*}{$\mathrm{pH}$} & \multirow[b]{2}{*}{ Remarks } \\
\hline & & & & & $\begin{array}{c}\text { Resi- } \\
\text { due on } \\
\text { evapo- } \\
\text { ration } \\
\text { at } 180^{\circ} \\
\mathrm{C}\end{array}$ & Suln & $\begin{array}{c}\text { Cal- } \\
\text { cium } \\
\text { mag- } \\
\text { nesi- } \\
\text { um }\end{array}$ & $\begin{array}{l}\text { Yon- } \\
\text { cal- } \\
\text { bon- } \\
\text { ate }\end{array}$ & & & & \\
\hline
\end{tabular}

Madison Limestone and Bighorn Dolomite-Continued

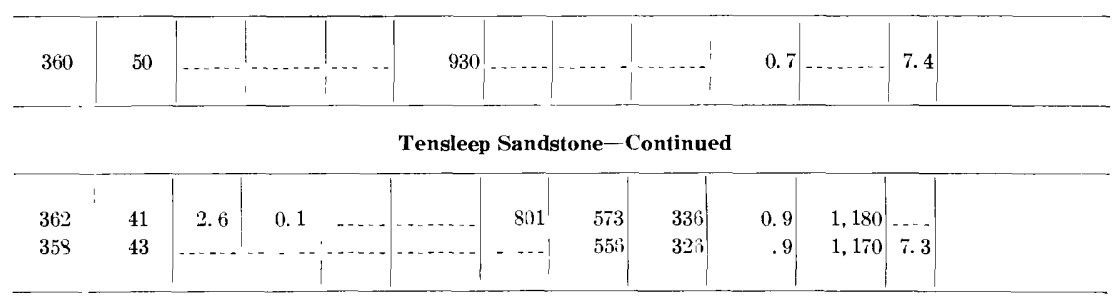

Permian rocks and (or) Dinwoody Formation-Continued

\begin{tabular}{|c|c|c|c|c|c|c|c|c|c|c|c|c|}
\hline & & & & & & & & & & & & \\
\hline 1,560 & 219 & 2. 1 & 0.0 & 0.48 & 3,240 & 3,210 & 1,300 . & 698 & 6.7 & 3,920 & . & \\
\hline 2,320 & 76 & 1. 1 & .1 & .06 & 4,030 & 3,690 & 1,820 & 1,520 & 4.8 & 4,230 & 8. 2 & Mn 0.59 ppln. \\
\hline
\end{tabular}

Jurassic, Jurassic(?), and Triassic(?) rocks-Continued

\begin{tabular}{ll|l|l|l|l|l|l|l|l|l|l|}
\hline 11,100 & 6,260 & 1.0 & 0.3 & $\ldots .$. & 27,200 & 26,300 & 11,300 & 11,000 & $\ldots \ldots$ & 31,700 & 7.2 \\
\hline
\end{tabular}

Frontier Formation-Continued

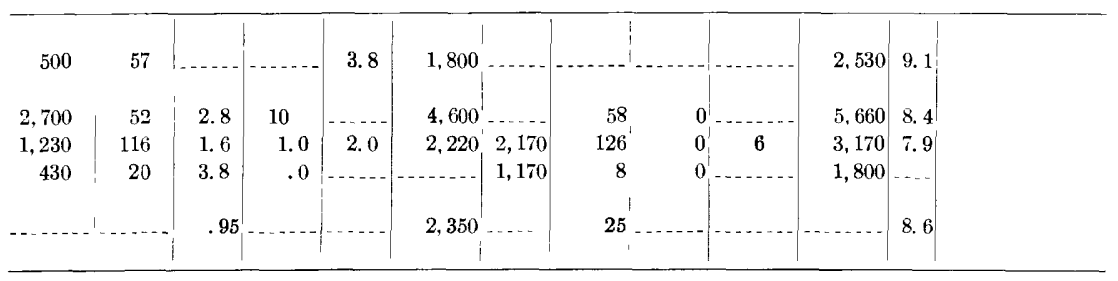

Cody Shale-Continued

\begin{tabular}{|c|c|c|c|c|c|c|c|c|c|c|c|c|}
\hline $\begin{array}{r}730 \\
1,520\end{array}$ & $\begin{array}{r}182 \\
37\end{array}$ & $\begin{array}{l}1.2 \\
1.2\end{array}$ & $\begin{array}{l}4.3 \\
1.0\end{array}$ & 0.21 & 2,450 & $\begin{array}{l}1,750 \\
2,430\end{array}$ & $\begin{array}{r}87 \\
194\end{array}$ & $\begin{array}{r}0 \\
81\end{array}$ & $\begin{array}{l}36 \\
16\end{array}$ & $\begin{array}{l}2,660 \\
3,380\end{array}$ & $\begin{array}{l}-. \\
7.5\end{array}$ & \\
\hline \multicolumn{13}{|c|}{ Fort Union Formation-Continued } \\
\hline 1.5 & 291 & 2.6 & 0.0 & 0.18 & 1,010 & 995 & 28 & 0 & 32 & 1,760 & 8.4 & Mn 0.09 ppm. \\
\hline 1 & 270 & 1.8 & 0 & .10 & 992 & $\ldots$ & 30 & -- & 30 & 1. 720 & 8,6 & \\
\hline
\end{tabular}


TABLE 6.-Chemical analyses of ground-water samples,

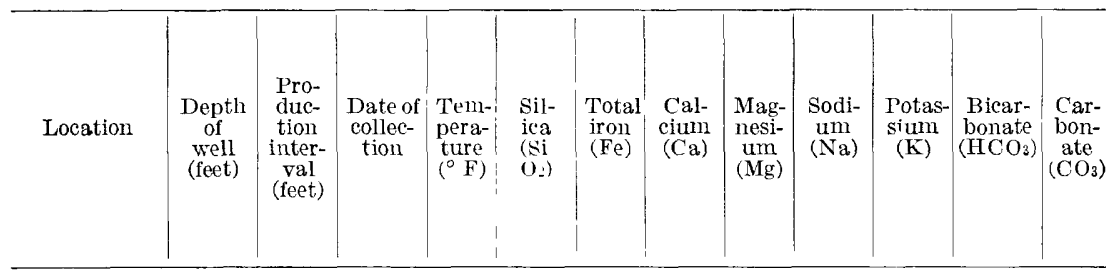

\section{Wind River Formation}

\begin{tabular}{|c|c|c|c|c|c|c|c|c|c|c|c|c|}
\hline Al-1-3bbb_... & 579 & $\begin{array}{r}559(?)- \\
579\end{array}$ & $8-31-66$ & 53 & 1.8 & & 16 & 9.7 & 96 & 2.5 & 204 & 0 \\
\hline A 1-3-16cea-... & 103. & $\ldots-$ & $10-19-48$ & 50 & 15 & 0.02 & 81 & 82 & 171 & 4. 0 & 157 & 0 \\
\hline $17 \mathrm{add}$ & $\left.285\right|_{2}$ & $246-280$ & $11-8-65$ &.- & 11 & .36 & 4.2 & .4 & 148 & .4 & 52 & 2 \\
\hline A1-4-3ddd.... & 124 . & -1 & $|10-20-48|$ & 52 & 26 & 3.0 & 64 & 15 & 98 & .8 & 388 & 0 \\
\hline $12 \mathrm{ecc}$ & 64 & & $10-21-48$ & 51 & 19 & .32 & 42 & 14 & 21 & .8 & 145 & 3.9 \\
\hline $24 \mathrm{caa} \ldots$ & 70 & & $10-21-48$ & 50 & 12 & 1.4 & 5.0 & 2.2 & 226 & .8 & 85 & 4.9 \\
\hline $27 \mathrm{cda}{ }^{4}-$ & 6452 & $255-645$ & $10-21-60$ & 57 & 13 & .13 & 1.6 & 1.0 & 126 & 1. 6 & 184 & 10 \\
\hline $27 \mathrm{ddd} 4$ & 6003 & $353-600$ & $|10-22-4 x|$ & 55 & 13 & 2.03 & 65 & .3 & 142 & .4 & 191 & 7 \\
\hline $27 \mathrm{ddd}^{4}--$ & 600 & $353-600$ & 9-23-54 & 54 & 11 & 2.00 & 1.5 & .1 & 142 & 1. 7 & 185 & 12 \\
\hline $27 \mathrm{ddd}^{4}-$ & 6003 & $353-600 \mid$ & $|12-3-65|$ &.- & 12 & ${ }^{2} .00$ & .8 & .2 & 136 & .9 & 204 & 0 \\
\hline $\mathrm{A} 1-4-32 \mathrm{bda}-\ldots$ & 367 & $\mid \ldots$ & $10-15-48$ & 50 & 9.5 & 2.4 & 8.5 & .2 & 155 & 2.8 & 131 & 1 \\
\hline $34 a d d 4 .-$ & 609 & $|345-609|$ & $10-27-51$ & 56 & 11 & .01 & 2.9 & .1 & 160 & .5 & 192 & 9 \\
\hline $34 a d d^{4}-$ & $609:$ & $345-609$ & $12-2-65$ & 50 & 7.5 & .00 & 1.2 & 1.7. & 165 & 1.4 & $18 i$ & 10 \\
\hline $34 b^{4}{ }^{4}-$ & 535 & $440-535$ & $12-2-65$ & 50 & 8.3 & .00 & .8 & .1 & 132 & .9 & 165 & 21 \\
\hline $3.4 b b d^{4}-$ & 660 & $460-660$ & $10-26-51$ & & 12 & .06 & 23 & 1. 1 & 125 & .7 & 101 & 8 \\
\hline A2-1-24ecd & 180 & & $9-15-65$ & 55 & 26 & .13 & 94 & 14 & 15 & 3.1 & 334 & 0 \\
\hline A2-2-4ıled & 40 & $\cdots$ & $9-17-49$ & 49 & 10 & 2.0 & 370 & 70 & 403 & 6.4 & 236 & 0 \\
\hline 15 dea $1 .$. & 22 & $|\ldots \ldots|$ & $10-18-4 x$ & 50 & 14 & .08 & 37 & 5.9 & 167 & 18 & 386 & 0 \\
\hline 17aaa... & 500 & $486-500$ & $10-18-48$ & 50 & 25 & 2.8 & 34 & 1.5 & 148 & 1.2 & 186 & 0 \\
\hline 18ada1. & 485 & & $11-1-60$ &.- & 20 & .00 & 59 & 7.8 & 72 & 2.0 & 190 & 0 \\
\hline A2-3-10bec $\ldots$ & 85 & $60-65$ & $10-19-48$ & 49 & 11 & .16 & 23 & 3.4 & 250 & 3.6 & 152 & 0 \\
\hline $19 \mathrm{dda}$ & 228 & $202-228$ & $9-17-49$ & 50 & 10 & 2.0 & 14 & .6 & 235 & 4.0 & 35 & 0 \\
\hline 26dea.... & 80 & $35-55$ & $9-17-49$ & 49 & 10 & 2.4 & 62 & .5 & 579 & 4. 8 & 28 & 0 \\
\hline A2-4-2cbc & 50 & $\ldots$ & $10-20-48$ & 50 & 16 & 1. 1 & 13 & 1.7 & 343 & 2.4 & 561 & 0 \\
\hline 10rlec & 350 & $330-350$ & $9-17-49$ & 52 & 10 & .54 & 16 & .4 & 260 & 4. 8. & 34 & 0 \\
\hline 17ada... & 40 & $\ldots$ & $10-20-48$ & 49 & 12 & .26 & 12 & 1.3 & 350 & 21 & 625 & 14 \\
\hline A2-5-2aba... & 306 & $275-300$ & $10-20-48$ & 50 & 16 & .16 & 14 & 1.5 & 261 & .8 & 34 & 0 \\
\hline $30 \mathrm{cdd}$ & 177 & $165-167$ & $|10-21-48|$ & 52 & 10 & 1.9 & 10 & .1 & 248 & .4 & 163 & 0 \\
\hline $7 \mathrm{eda}$ & 128 & $108-125$ & $9-17-4 !$ & 52 & 8.8 & .96 & 8.0 & 10 & 235 & 4.8 & 138 & 0 \\
\hline A2-6-19dab $\ldots$ & 360 & $300-353$ & $10-20-48$ & 55 & 13 & 2.0 & 26 & 4. 6 & 284 & .8 & 126 & 6 \\
\hline A3-1-9cda & 207 & $150-206$ & $\mid 11-1-66$ & $\ldots$ & 18 & $\ldots$ & 201 & 20 & 759 & 2.8 & 445 & 0 \\
\hline $21 a d d . .$. & 226 & $183-225$ & $10-14-48$ & 52 & 13 & .60 & 46 & 2.0 & 458 & 4.4 & 85 & 0 \\
\hline $21 b a b_{-}{ }_{-}$ & 40 & $\mid \ldots$ & $y-17-49$ & 51 & 14 & 1.1 & 81 & 24 & 86 & 3.2 & 284 & 0 \\
\hline 21ddr. . - & 75 & & $10-14-48$ & 50 & 28 & 4.0 & 282 & 73 & 414 & 2.4 & 414 & 0 \\
\hline 25bed_ _ - & 223 & $66(?)$ & (17-49) & 49 & 14 & 8.0 & 230 & 59 & 966 & 6.4 & 512 & 0 \\
\hline $36 a d a$ & 77 & ....... & $10-14-48$ & 50 & 13 & 2.2 & 450 & 167 & 748 & 5.6 & 342 & 0 \\
\hline A3-2-5bcb_- - & 100 & 70-100 & $8-14-50$ & 58 & 10 & - & 33 & .5 & 459 & 1.3 & $78 !$ & 0 \\
\hline 6ace..... & 41 & . & $6-18-51$ & 50 & . & & & & 253 & 2.6 & 134 & 0 \\
\hline $6 a c c . \ldots$ & 41 & & $6-19-51$ & 49 & & & & & 362 & 3.7 & 164 & 0 \\
\hline $7 \mathrm{cca} . .$. & 398 & $300-398$ & $10-29-60$ & - & 16 & 30 & 8.0 & 0 & 210 & .4 & 88 & 2 \\
\hline 10acc... & 482 & $466-482$ & $10-18-48$ & 50 & 14 & 1. 6 & 6.0 & .6 & 174 & 5.2 & 44 & 0 \\
\hline $26 \mathrm{adc} \ldots$ & 321 & $296-321$ & $10-18-48$ & 53 & 13 & 2.0 & 46 & .1 & 445 & 7. 6 & 22 & 0 \\
\hline
\end{tabular}

See footnotes at end of table. 
Wind River Indian Reservation, Wyo.-Continued

\begin{tabular}{|c|c|c|c|c|c|c|c|c|c|c|c|c|}
\hline \multirow[b]{2}{*}{$\begin{array}{l}\text { Sulfate } \\
\left(\mathrm{SO}_{4}\right)\end{array}$} & \multirow[b]{2}{*}{$\begin{array}{l}\text { Chlo- } \\
\text { ride } \\
\text { (Cl) }\end{array}$} & \multirow[b]{2}{*}{$\begin{array}{l}\text { Fluo- } \\
\text { ride } \\
\text { (F) }\end{array}$} & \multirow[b]{2}{*}{$\begin{array}{c}\mathrm{Ni}- \\
\text { trate } \\
\left(\mathrm{NO}_{3}\right)\end{array}$} & \multirow[b]{2}{*}{$\begin{array}{l}\text { Bo- } \\
\text { ron } \\
\text { (B) }\end{array}$} & \multirow{2}{*}{\multicolumn{2}{|c|}{$\begin{array}{c:c}\begin{array}{c}\text { Dissolyed } \\
\text { solids }\end{array} \\
\text { Resi- } \\
\text { due on } & \\
\text { evapo- } & \text { Sum } \\
\text { ration } & \\
\text { at } 180^{\circ} & \\
\mathrm{C} & \end{array}$}} & \multicolumn{2}{|c|}{$\begin{array}{l}\text { Hardness } \\
\text { as } \mathrm{CaCO}_{3}\end{array}$} & \multirow{2}{*}{$\begin{array}{c}\text { Sodi- } \\
\text { um-ad- } \\
\text { sorp- } \\
\text { tion- } \\
\text { ratio } \\
\text { (SA R) }\end{array}$} & \multirow{2}{*}{$\begin{array}{l}\text { Spe- } \\
\text { cific } \\
\text { con- } \\
\text { duct- } \\
\text { ance } \\
\text { (micro- } \\
\text { mhos at } \\
25^{\circ} \mathrm{Cl}\end{array}$} & \multirow[b]{2}{*}{$\mathrm{pH}$} & \multirow[b]{2}{*}{ Remarks } \\
\hline & & & & & & & $\begin{array}{c}\text { Cal- } \\
\text { ciumı } \\
\text { mag- } \\
\text { nesi- } \\
\text { umm }\end{array}$ & $\begin{array}{l}\text { Non- } \\
\text { car- } \\
\text { bon- } \\
\text { ate }\end{array}$ & & & & \\
\hline
\end{tabular}

Wind River Formation-Continued

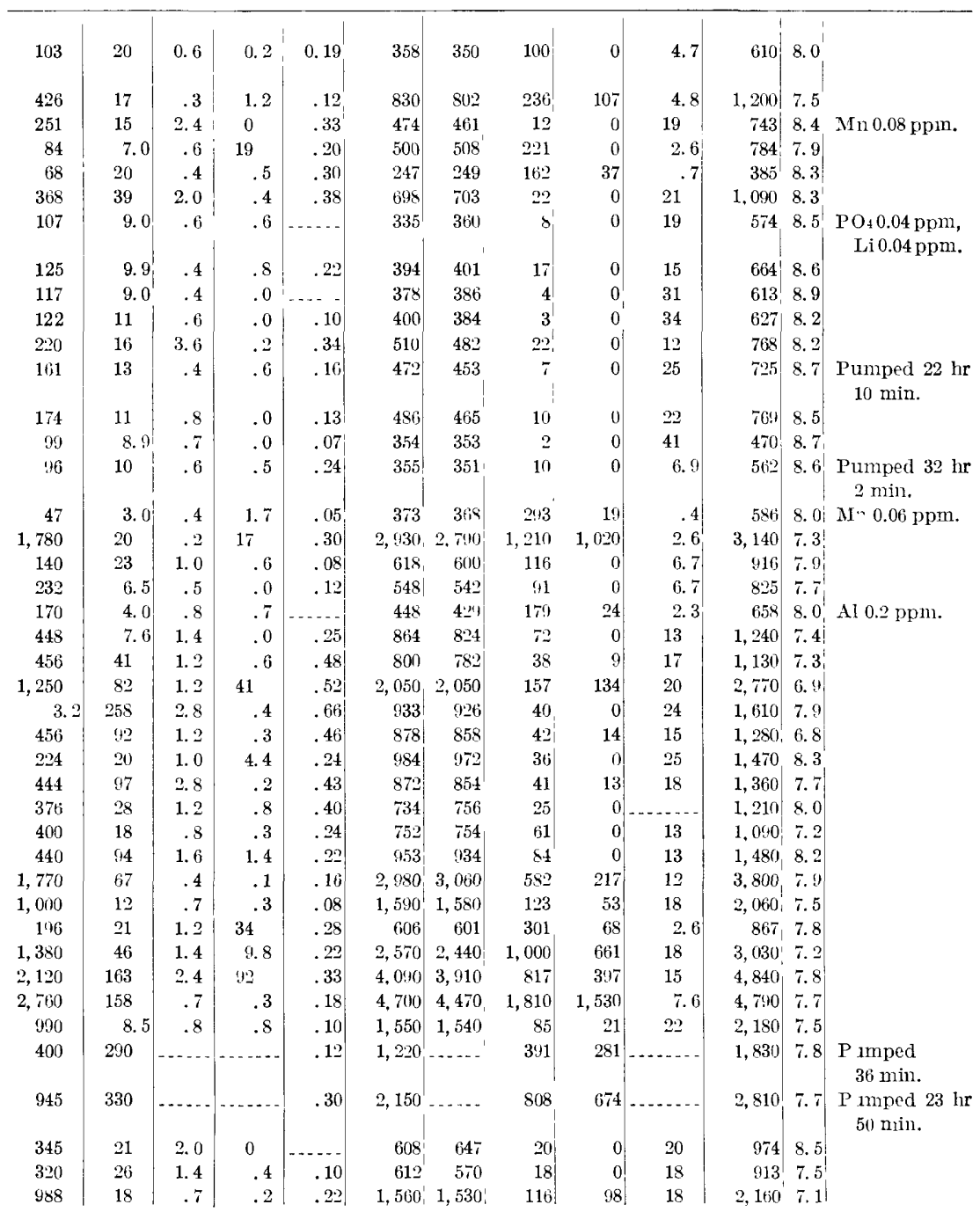


TABLE 6.-Chemical analyses of ground-water samples,

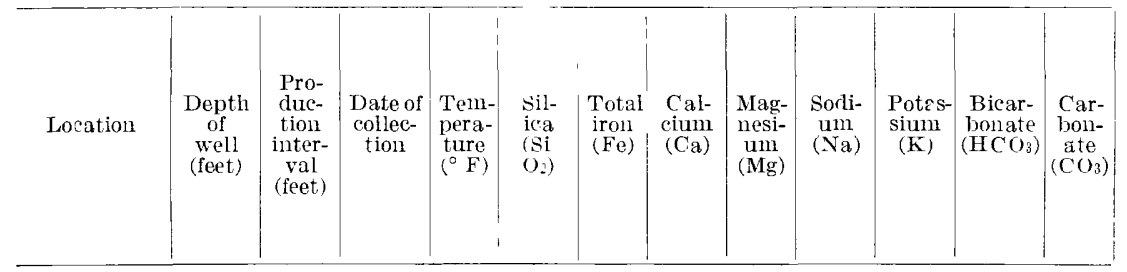

Wind River For mation-Continued

\begin{tabular}{|c|c|c|c|c|c|c|c|c|c|c|c|c|}
\hline A3-2-27baa . . & 57 & $\ldots$ & $12-5-50^{\prime}$ & $4 !$ & 12 & $0.108^{\prime}$ & 488 & $16 \pi$ & 282 & 53 & 256 & 0 \\
\hline $30 d d b \ldots$ & 582 & $215^{-2}-230$ & $\mid 10-18-48$ & 52 & 15 & .03 & 70 & 2.6 & 579 & 7. 2 & 119 & 0 \\
\hline A3-3-6cec - & 270 & $240-270$ & $10-26-51$ & 52 & 21 & $\ldots$ & .4 & .1 & 97 & .2 & 74 & 33 \\
\hline lficbe ... & 360 & $340-360$ & $10-18-48$ & 50 & 17 & .60 & 12 & .1 & 217 & 1.2 & 34 & 0 \\
\hline $24 \mathrm{cec} \ldots .$. & 50 & $37-50$ & $10-20-48$ & 49 & 16 & 2.1 & 460 & 179 & 714 & 10 & 175 & 0 \\
\hline $26 a b a_{\ldots} \ldots$ & 244 & $228-244$ & $10-19-48$ & 49 & 11 & .28 & 27 & .1 & 332 & 40 & 23 & 0 \\
\hline A3-4-29cdd $\ldots$ & 76 & - & $9-17-4 !$ & 49 & 9.2 & 3.0 & 74 & 7.9 & 473 & 48 & 416 & 0 \\
\hline A3-5-33dec & 35 & $\ldots$ & $10-16-48$ & 47 & $1 !$ & .06 & 206 & 41 & 735 & 32 & 330 & 0 \\
\hline A3-6-15bcb_.. & 495 & $451-495$ & $10-2 \bar{i}-60$ & -- & 10 & .08 & 4.8 & 1.0 & 179 & .6 & 168 & 2 \\
\hline A4-1-11bld . . & 185 & $110-175$ & $11-2-66$ & $\ldots$ & fi. & $\ldots$ & 149 & 15 & 1,500 & 63 & 212 & 0 \\
\hline $18 \mathrm{dbc} \ldots$ & 272 & $230-271$ & $11-2-66$ & -- & 11 & & 36 & 2.9 & 582 & .2 & 131 & 0 \\
\hline A4-2-25dba $\ldots$ & 266 & $248-258$ & $8-14-50$ & 50 & 12 & $-\infty$ & 31 & .1 & 548 & 1.8 & 64 & 0 \\
\hline A4-3-13dcb & 465 & $425-436$ & $10-26-51$ & 51 & 10 & .25 & 5.5 & .1 & 256 & .6 & 32 & 16 \\
\hline $34 a a_{2} .$. & 305 & $278-302$ & $10-20-51$ & 50 & 12 & $\ldots$ & 7.5 & .1 & 264 & .2 & 43 & 0 \\
\hline $36 \mathrm{db} \mathrm{b}_{\ldots}$. & $120^{\prime}$ & & $10-2 !-60$ & & 28 & .13 & 320 & 224 & 520 & 82 & 254 & 0 \\
\hline A4-4-20dad $\ldots$ & 234 & $170-210$ & $10-26-51$ & 52 & ๙. 0 & 1. 6 & 31 & .9 & 556 & .9 & 34 & 0 \\
\hline 23alsd1. & 621 & $411-590$ & $6-26-51$ & 53 & 6.8 & .08 & 14 & .7 & 380 & .6 & 78 & 0 \\
\hline $28 \mathrm{cdc}$ & $>87$ & -. & $10-19-48$ & 48 & 13 & .30 & 186 & 69 & 354 & 60. & 285 & 0 \\
\hline A.5-4-21ecd $\ldots$ & $2 \neq 6$ & $270-245$ & $10-26-66$ & & 5.7 & $\ldots$ & 34 & $8.0^{\circ}$ & 819 & 30 & 72 & 0 \\
\hline A5-5-33aba_- & 190 & $182-188$ & $10-20-66$ & & 4.9 & & 52 & 7.9 & 1,070 & 30 & 76 & 0 \\
\hline $\mathrm{B} 3-1-24 \mathrm{Cda}^{1} \ldots$ & $40^{\prime}$ & $\ldots$ & $9-17-49$ & & 32 & .01 & 70 & 29 & 124 & 3.2 & 405 & 15 \\
\hline B3-3-4aba.... & $5 \overline{5}$ & $30-55$ & $11-4-65$ & & 23 & .05 & 39 & 17 & 66 & .8 & 190 & 0 \\
\hline B4-1-4cbb_- & 166 & $155-165$ & $10-31-6 b$ & & 5.4 & & 9.6 & 1. 9 & 261 & 1.0 & $140^{\mid}$ & 2 \\
\hline 25daa $\ldots$ & 487 & $\mid-\ldots \ldots$ & $|12-19-66|$ & & 1.8 & & 32 & 3.2 & 342 & 1.8 & 50) & 4 \\
\hline B6-3-33ced_... & 96 & $90-45$ & $10-31-66$ & & 6.2 & & 11 & .1 & 294 & .4 & 90 & 0 \\
\hline D1-3-2aba ${ }^{3} \ldots$ & 60 & $\ldots \ldots$ & $11-4-64$ & & $\ldots$ & & 27 & 5 & 80 & 1 & 211 & 0 \\
\hline $7 \mathrm{ded} \ldots$ & 130 & $94-128$ & $|1-3-66|$ & & 12 & & 102 & 15 & 56 & 2.0 & 180 & 0 \\
\hline $10 c c a^{3}-\ldots$ & 390 & $244-253$ & $10-29-64$ & & $\ldots \ldots$ & & 1 & 2 & 175 & 1 & 211 & 21 \\
\hline $10 c e a^{3}--$ & 390 & $375-390$ & $10-27-64$ & & & & 3 & 3 & 155 & 0 & 153 & 24 \\
\hline $13 a a b^{3} \ldots$ & 300 & $\ldots \ldots$ & $11-12-64$ & 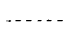 & . & 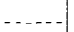 & 28 & 4 & 190 & 1 & 211 & 6 \\
\hline 13 dad $^{3} \ldots$ & 80 & $55-65$ & $11-19-64$ & & & & 148 & 16 & 310 & 3 & 241 & 0 \\
\hline $14 b b d^{3}-$. & 108 & $91-108$ & $\mid 11-19-64$ & & - & $\cdots$ & 163 & 5 & 580 & 1 & 85 & 0 \\
\hline D1-3-17bcb - - & 150 & $95-140$ & $\mid 11-3-65$ & -- & 17 & .17 & 59 & 12 & 73 & 2.1 & 162 & 0 \\
\hline $23 a d c^{3}--$ & 60 & $\ldots \ldots$ & $11-19-64$ & & - & & 146 & 39 & 130 & 1 & 226 & 0 \\
\hline $23 \mathrm{cba}$ & 550 & -....... & $5-18-45$ & & & & 1.5 & 2.2 & \multicolumn{2}{|c|}{150} & 166 & 12 \\
\hline $24 \mathrm{cbd}^{3}--$ & 235 & $220-330$ & $\mid 11-19-64$ & & $\cdots$ & & 5 & 2 & 175 & 1 & 122 & 15 \\
\hline $\mathrm{D} 1-4-4 \mathrm{cdd} \ldots$ & 450 & $320-450$ & $9-30-64$ & & 7.0 & .06 & 2.0 & 1.0 & 139 & 1.0 & \multicolumn{2}{|c|}{223} \\
\hline $18 \mathrm{bba}^{3}--$ & 330 & At 57 & $|10-16-64|$ & & & & 424 & 58 & 521 & 3 & 305 & 0 \\
\hline $18 \mathrm{bba}^{3}--$ & 330 & $314-325$ & $\mid 10-26-64$ & --- & 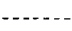 & & 4 & 2 & 150 & 1 & 156 & 18 \\
\hline D1-5-11ace_-- & 225 & $118-215$ & $\mid 11-5-65$ & 55 & 16 & .26 & 150 & 39 & 340 & 7.4 & 469 & 0 \\
\hline $12 \mathrm{db} . \ldots$ & 800 & $300-800$ & $|12-3-65|$ & & 19 & 2.03 & 51 & 22 & 92 & 5.4 & 177 & 0 \\
\hline
\end{tabular}

Glacial deposits

\begin{tabular}{|c|c|c|c|c|c|c|c|c|c|c|c|c|}
\hline B3-2-17acb--- & 45 & At 45 & $11-4-65$ & $5 \ldots$ & 19 & 0.10 & 46 & 10 & 18 & 2.4 & 170 & 0 \\
\hline
\end{tabular}

See footnotes at end of table. 
Wind River Indian Reservation, Wyo.-Continued

\begin{tabular}{|c|c|c|c|c|c|c|c|c|c|c|c|c|}
\hline \multirow{2}{*}{$\begin{array}{c}\text { Sulfate } \\
\left(\mathrm{SO}_{4}\right)\end{array}$} & \multirow{2}{*}{$\begin{array}{l}\text { Chlo- } \\
\text { ride } \\
\text { (C1) }\end{array}$} & \multirow{2}{*}{$\begin{array}{c}\text { Fluo- } \\
\text { ride } \\
\text { (F) }\end{array}$} & \multirow{2}{*}{$\begin{array}{c}\mathrm{Ni}- \\
\text { trate } \\
\left(\mathrm{NO}_{3}\right)\end{array}$} & \multirow{2}{*}{$\begin{array}{l}\mathrm{BO}- \\
\text { roll } \\
(\mathrm{B})\end{array}$} & \multicolumn{2}{|c|}{$\begin{array}{l}\text { Dissolved } \\
\text { solids }\end{array}$} & \multicolumn{2}{|c|}{$\begin{array}{l}\text { Hardness } \\
\text { as CaC } \mathrm{C}_{3}\end{array}$} & \multirow{2}{*}{$\begin{array}{c}\text { Sodi- } \\
\text { um-ad- } \\
\text { sorp- } \\
\text { tion- } \\
\text { ratio } \\
\text { (SAR) }\end{array}$} & \multirow{2}{*}{$\begin{array}{c}\text { Spe- } \\
\text { cific } \\
\text { con- } \\
\text { duct- } \\
\text { ance } \\
\text { (micro- } \\
\text { mhos at } \\
25^{\circ} \mathrm{C} \text { ) }\end{array}$} & \multirow[b]{2}{*}{$\mathrm{pH}$} & \multirow[b]{2}{*}{ Remarks } \\
\hline & & & & & $\begin{array}{l}\text { Resi- } \\
\text { due on } \\
\text { evapo- } \\
\text { ration } \\
\text { at } 180^{\circ} \\
\mathrm{C}\end{array}$ & Sum & $\begin{array}{c}\text { Cal- } \\
\text { cium } \\
\text { mag- } \\
\text { nesi- } \\
\text { uni }\end{array}$ & $\begin{array}{l}\text { Non- } \\
\text { cal- } \\
\text { bon- } \\
\text { ate }\end{array}$ & & & & \\
\hline
\end{tabular}

\section{Wind River Formation---Continued}

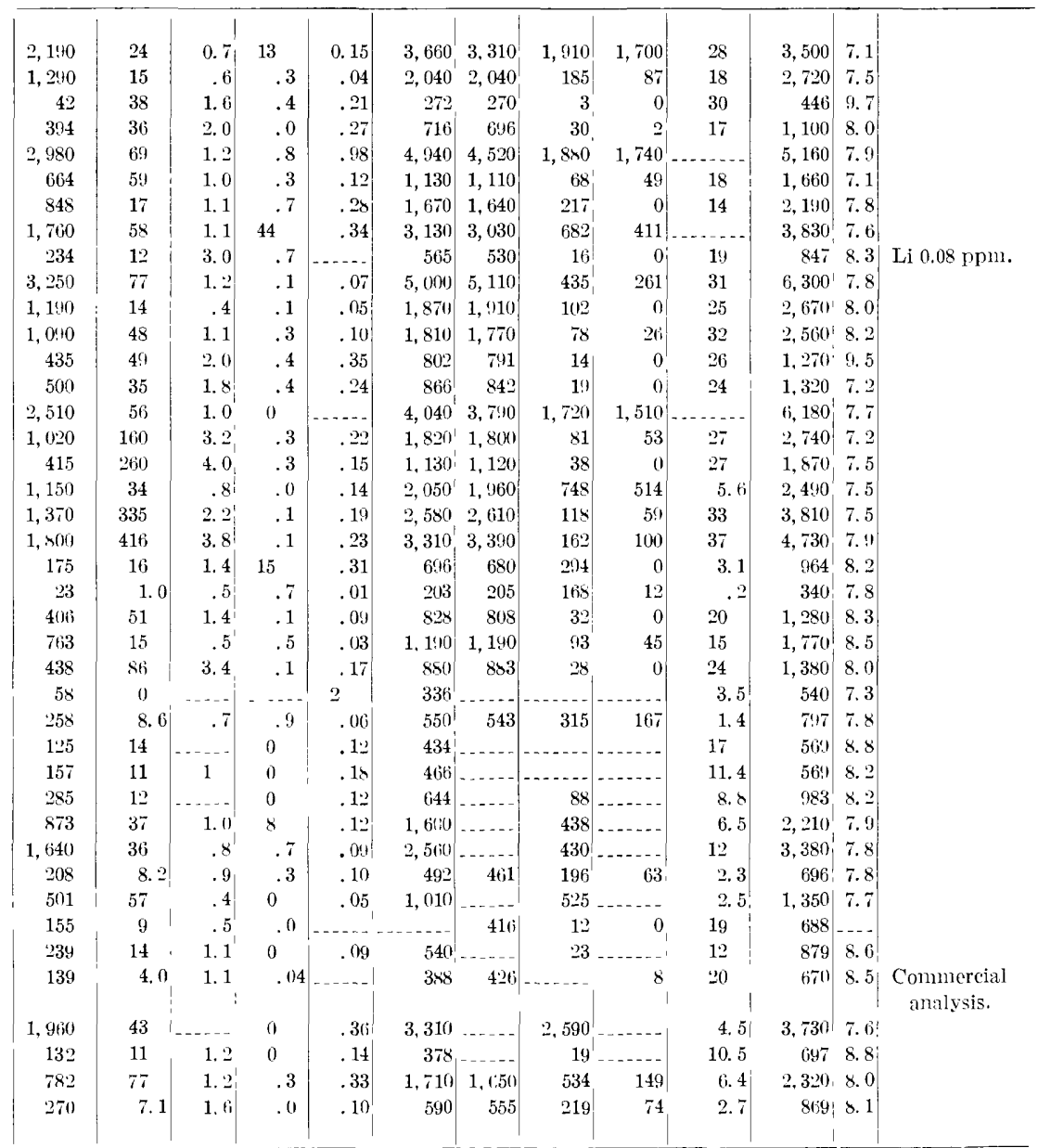

\section{Glacial deposits-Continued}

\begin{tabular}{|c|c|c|c|c|c|c|c|c|c|c|c|}
\hline 52 & 4.0 & 0.2 & 0.2 & 0.03 & 240 & 236 & $15 \%$ & $18^{\prime}$ & 0.6 & 381 & 7.7 \\
\hline
\end{tabular}


TABLE 6.-Chemical analyses of ground-water samples,

\begin{tabular}{|c|c|c|c|c|c|c|c|c|c|c|c|c|}
\hline Location & $\begin{array}{c}\text { Depth } \\
\text { of } \\
\text { well } \\
\text { (feet) }\end{array}$ & $\begin{array}{c}\text { Pro- } \\
\text { duc- } \\
\text { tion } \\
\text { inter- } \\
\text { val } \\
\text { (feet) }\end{array}$ & $\begin{array}{l}\text { Date of } \\
\text { collec- } \\
\text { tion }\end{array}$ & $\begin{array}{c}\text { Tem- } \\
\text { pera- } \\
\text { ture } \\
\left({ }^{\circ} \mathrm{F}\right)\end{array}$ & $\begin{array}{l}\text { Sil- } \\
\text { ica } \\
(\mathrm{Si} \\
\left.\mathrm{O}_{2}\right)\end{array}$ & $\begin{array}{l}\text { Total } \\
\text { ironl } \\
(\mathrm{Fe})\end{array} \mid$ & $\begin{array}{c}\text { CaI- } \\
\text { cium } \\
(\mathrm{Ca})\end{array}$ & $\begin{array}{c}\text { Mag- } \\
\text { nesi- } \\
\operatorname{umm}_{(\mathrm{Mg})}\end{array}$ & $\begin{array}{l}\text { Sodi- } \\
\text { umi } \\
(\mathrm{Na})\end{array}$ & $\begin{array}{l}\text { Potass- } \\
\text { sium } \\
(F .)\end{array}$ & $\begin{array}{c}\text { Bicar- } \\
\text { bonate } \\
\left(\mathrm{HCO}_{3}\right)\end{array}$ & $\begin{array}{l}\text { Car- } \\
\text { bon- } \\
\text { ate } \\
\left(\mathrm{CO}_{3}\right)\end{array}$ \\
\hline
\end{tabular}

Terrace deposits near Wind River

\begin{tabular}{|c|c|c|c|c|c|c|c|c|c|c|c|c|}
\hline$A 1-4-32 a d b$ & 12 & & $10-15-48$ & 54 & 38 & 0.34 & 87 & 13 & 56 & 6.4 & 368 & 0 \\
\hline B4-3-32baa . & 41 & 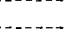 & $4-28-66$ & - & 30 & .04 & 35 & 19 & 24 & 1. 0 & 223 & 0 \\
\hline B4-4-22aba_.- & 33 & $21-33$ & $10-26-66$ & 50 & 31 & -- & 64 & 12 & 86 & 1. 6 & 392 & 0 \\
\hline $23 a d c$ & & .... & $4-28-66$ & & 24 & .00 & 47 & 42 & 144 & 2.0 & 566 & 0 \\
\hline
\end{tabular}

Terrace deposits near Muddy Creek

\begin{tabular}{r|r|r|r|r|r|r|r|r}
\hline A4-4-23acd & 23 & $11-19$ & $6-26-51$ & & & & & \\
$23 d b d 2 .-$ & 20 & $8-15$ & $10-26-51$ & & & & 334 & 7 \\
14
\end{tabular}

Alluvium of Mill Creek valley

\begin{tabular}{|c|c|c|c|c|c|c|c|c|c|c|c|c|}
\hline D1-1-15ece & 38 & $16-38$ & $10-25-66$ & 52 & 17 & & 358 & 94 & 258 & 5.4 & 342 & 0 \\
\hline 2:bbal_ & 30 & $-\ldots$ & $8-13-65$ & $\ldots 1$ & 17 & 0.05 & 238 & 121 & 226 & 4.6 & 313 & 0 \\
\hline 22bba1 & 30 & $\ldots-\ldots$ & $-4-28-66$ & $\ldots$ & 16 & $.00^{\prime}$ & 223 & 127 & 235 & 5.0 & 342 & 0 \\
\hline $22 \mathrm{beb}$ & $21^{\prime}$ & $19-21$ & $10-5-65$ & 53 & 19 & .45 & 227 & 156 & 316 & 6.0 & 329 & 0 \\
\hline $31 \mathrm{dda} .$. & 45 & - & $-10-6-65$ & 49 & 18 & .46 & 63 & 26 & 15 & 2.3 & 284 & 0 \\
\hline $32 \operatorname{acd} 1_{-}$ & 45 & - - - & $-\mid 10-5-65$ & $\ldots$ & 19 & .07 & 49 & 31 & 11 & 2.1 & 284 & 0 \\
\hline
\end{tabular}

Alluvium of Kirby Draw

\begin{tabular}{|c|c|c|c|c|c|c|c|c|c|c|c|}
\hline A 1-5-15aab_.. & 29 & $9-28-65$ & 51 & 12 & 0.80 & 42 & 8.0 & 461 & 1. 9 & 417 & 0 \\
\hline D1-5-11bdd... & $34^{\prime}$ & $32-3410-6-65$ & 52 & 14 & .34 & 168 & 55 & 1,100 & 4.7 & 409 & 0 \\
\hline
\end{tabular}

Alluvium of Beaver Creek valley

\begin{tabular}{r|r|r|r|r|r|r|r|r|r|r|r|r|r|r|r|r|r|r|}
\hline D1-4-33daa ... & 22 & $20-22$ & $9-28-65$ & 52 & 18 & 1.3 & 184 & 48 & 169 & 7.4 \\
\hline
\end{tabular}

Alluvium of Crow Creek valley

\begin{tabular}{|c|c|c|c|c|c|c|c|c|c|c|c|}
\hline B4-3-8bbd.... & 30. & $11-4-65$ & & 29 & 0.37 & 104 & 17 & 89 & 3,6 & 526 & 0 \\
\hline
\end{tabular}

Alluvium of Owl Creek valley

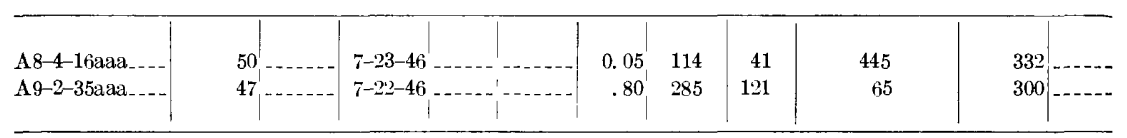

see footnotes at end of table. 
Wind River Indian Reservation, Wyo.-Continued

\begin{tabular}{|c|c|c|c|c|c|c|c|c|c|c|c|c|}
\hline \multirow{2}{*}{$\begin{array}{c}\text { Sulfate } \\
\left(\mathrm{SO}_{4}\right)\end{array}$} & \multirow{2}{*}{$\begin{array}{l}\text { Chlo- } \\
\text { ride } \\
\text { (Cl) }\end{array}$} & \multirow{2}{*}{$\begin{array}{c}\text { Fluo- } \\
\text { ride } \\
(\mathrm{F})\end{array}$} & \multirow{2}{*}{$\begin{array}{c}\mathrm{Ni}- \\
\text { trate } \\
\left(\mathrm{NO}_{3}\right)\end{array}$} & \multirow{2}{*}{$\begin{array}{l}\mathrm{Bo-} \\
\text { ron } \\
(\mathrm{B})\end{array}$} & \multicolumn{2}{|c|}{$\begin{array}{l}\text { Dissolved } \\
\text { solids }\end{array}$} & \multicolumn{2}{|c|}{$\begin{array}{l}\text { Hardness } \\
\text { as } \mathrm{CaCO}{ }_{3}\end{array}$} & \multirow{2}{*}{$\begin{array}{l}\text { Sodi- } \\
\text { um-ad- } \\
\text { sorp- } \\
\text { tion- } \\
\text { ratio } \\
\text { (SAR) }\end{array}$} & \multirow{2}{*}{$\begin{array}{c}\text { Spe- } \\
\text { cific } \\
\text { con- } \\
\text { duct- } \\
\text { ance } \\
\text { (nicro- } \\
\text { mhos at } \\
25^{\circ} \mathrm{C} \text { ) }\end{array}$} & \multirow[b]{2}{*}{$p H$} & \multirow[b]{2}{*}{ Remarks } \\
\hline & & & & & $\begin{array}{c}\text { Resi- } \\
\text { due on } \\
\text { evapo- } \\
\text { ration } \\
\text { at } 180^{\circ} \\
\mathrm{C}\end{array}$ & Sum & $\begin{array}{c}\text { Cal- } \\
\text { cium } \\
\text { mag- } \\
\text { nesi- } \\
\text { um }\end{array}$ & $\begin{array}{l}\text { Non- } \\
\text { car- } \\
\text { bon- } \\
\text { ate }\end{array}$ & & & & \\
\hline
\end{tabular}

Terrace deposits near Wind River-Continued

\begin{tabular}{|c|c|c|c|c|c|c|c|c|c|c|c|}
\hline 86 & 7.0 & 1.2 & 0.6 & 0.16 & 494 & 479 & 270 & 0 & 1.5 & 738 & 7.5 \\
\hline 20 & 5.3 & .6 & 1.9 & .04 & 268 & 247 & 165 & 0 & .8 & 397 & 7.9 \\
\hline 71 & 7.2 & 1.3 & .7 & $.34^{\prime}$ & 446 & 468 & 210 & 0 & $2.6^{1}$ & 705 & 7. 6 \\
\hline 115 & 17 & 1.3 & 0 & .02 & 714 & 670 & 289 & 0 & 3. 7 & 1,100 & 8.0 \\
\hline
\end{tabular}

Terrace deposits near Muddy Creek-Continued

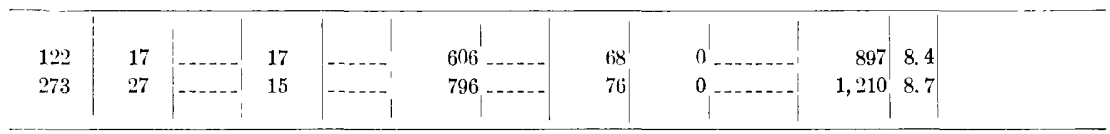

Alluvium of Mill Creek valley-Continued

\begin{tabular}{|c|c|c|c|c|c|c|c|c|c|c|c|c|}
\hline 1,470 & 21 & 1. 4 & 8.5 & 0.44 & 2,540 & 2,400 & 1,280 & 1,000 & $3.1^{\prime}$ & 2,740 & 7.6 & \\
\hline 1,200 & 17 & 1.0 & 6.0 & .47 & $2,230^{\prime}$ & 2,010 & 1,090 & 833 & 3.0 & 2,500 & 8.2 & \\
\hline 1,210 & 22 & .9 & 7.1 & .39 & 2,150 & 2,010 & 1,080 & 800 & 3.1 & 2,600 & 7.9 & \\
\hline 1,470 & 24 & .9 & 4. 0 & .63 & 2,640 & 2,390 & 1,210 & 940 & 4. 0 & $2,890^{\prime}$ & 8. 0 & Mn 0.45 ppm. \\
\hline 59 & 1. 9 & .9 & 1.4 & .08 & 329 & 328 & 264 & 31 & .4 & 543 & 8. 1 & Mn $0.03 \mathrm{ppm}$. \\
\hline 38 & 2.6 & .9 & 2.5 & .05 & 293 & 296 & 250 & 17 & .3 & 492 & 8.1 & MTn 0.03 ppm. \\
\hline
\end{tabular}

Alluvium of Kirby Draw-Continued

\begin{tabular}{|c|c|c|c|c|c|c|c|c|c|c|c|c|}
\hline & & & $i$ & & & | & & & & & & \\
\hline 695 & 31 & 1.5 & 0.00 & 0.27 & 1,490 & 1,460 & 138 & 0 & 17 & 2,140 & 8.2 & $\mathrm{M}_{\mathrm{n}} 0.54 \mathrm{ppm}$ \\
\hline 2,450 & 95 & .8 & .1 & .49 & 4,600 & 4,090 & 646 & 311 & 19 & 5,650 & 8. 2 & $\mathrm{rr}_{11} 0.12 \mathrm{ppm}$. \\
\hline
\end{tabular}

Alluvium of Beaver Creek valley-Continued

\begin{tabular}{|c|c|c|c|c|c|c|c|c|c|c|c|c|}
\hline 648 & 88 & 1.0 & 0.1 & 0.22 & 1,380 & 1,300 & 656 & 434 & 2.9 & 1,780 & 8. 1 & MIn 1.1 ppm. \\
\hline \multicolumn{13}{|c|}{ Alluvium of Crow Creek valley-Continued } \\
\hline 84 & 10 & 0.3 & 0.3 & 0.02 & 601 & 597 & 331 & 0 & 2. 1 & 911 & 7.9 & Mn $0.26 \mathrm{ppm}$ \\
\hline \multicolumn{13}{|c|}{ Alluvium of $O$ wl Creek valley - Continued } \\
\hline $\begin{array}{r}1.060 \\
1.040\end{array}$ & $\begin{array}{l}30 \\
16\end{array}$ & $\begin{array}{r}0.8 \\
9\end{array}$ & $\begin{array}{r}1.6 \\
0\end{array}$ & & $\mathbf{1 , 9 3 0}$ & -- & $\begin{array}{r}453 \\
\end{array}$ & 181 & 9. 1 & 2,440 & $\begin{array}{l}8.0 \\
7.3\end{array}$ & \\
\hline 1,040 & 16 & .2 & .0 & & 1,960 & $\ldots$ & 1,210 & 964 & .8 & 2,010 & 7.3 & \\
\hline
\end{tabular}


T.IBLE 6.-Chemical analyses of ground-r'ater samples,

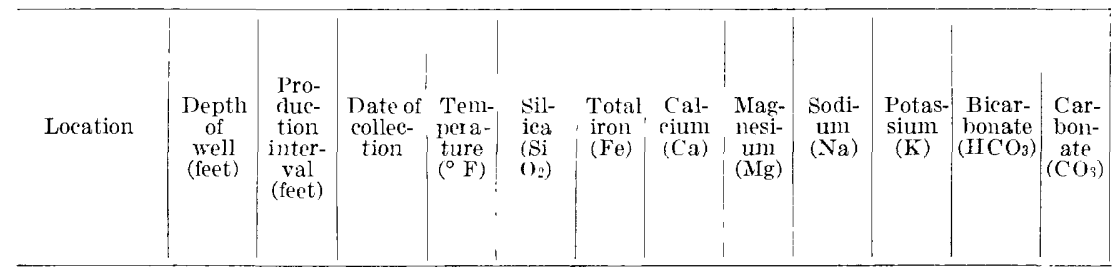

Alluvium of Little Wind River valley

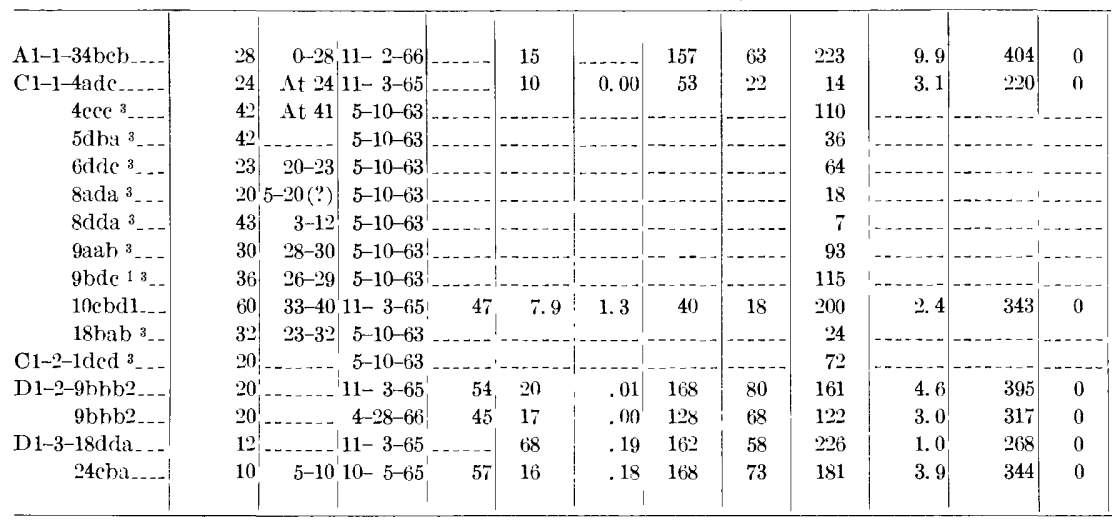

Alluvium of Wind River valley

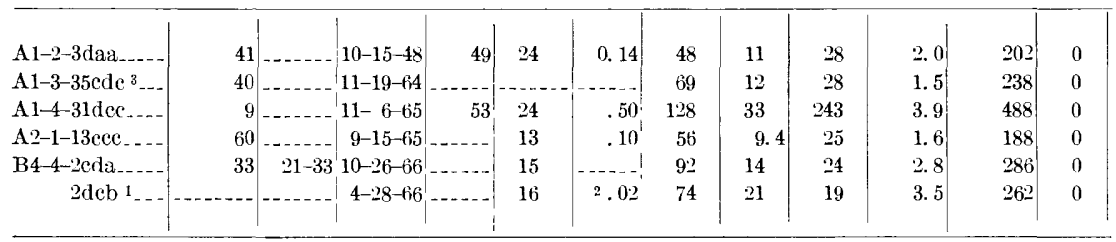

\begin{tabular}{|c|c|c|c|c|c|c|c|c|c|c|c|}
\hline \multicolumn{12}{|c|}{ Water-bearing formation unknown } \\
\hline A5-6-21aa_...- & $600-800$ & $--1---$ & $8-23-46$ & 6514 & 0.03 & 76 & 37 & 19 & -- & 275 & --- \\
\hline A $7-1-19 \mathrm{cca} \ldots$ & $\ldots$ & $\ldots$ & $4-28-65$ & 5411 & .00 & 52 & 28 & 5.0 & 2.2 & 224 & 0 \\
\hline C1-1-6edd 3 & 62 & $38-62$ & $5-10-63$ & 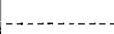 & - $-1-1$ & 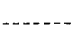 & $-\ldots$ & 250 & ------ & $-\ldots$ & $-\ldots--$ \\
\hline $8 a a b^{3}-1$ & 66 & $54-66$ & $5-10-63$ & & & & $\ldots$ & 160 & & & - \\
\hline $18 \mathrm{bec}^{3}--$ & 33 & $20-24$ & $5-10-63$ & & & & $-\ldots$ & 16 & & & $\ldots \ldots$ \\
\hline C1-2-24arla ${ }^{3}--$ & 41 & $36-41$ & $5-10-63$ & - & $-\ldots-\infty$ & $-\ldots$ & $-1-1$ & 6 & $-\ldots-n \mid$ & & $-\ldots$ \\
\hline $24 \mathrm{dab}^{3} \ldots$ & 90 & & $11-10-64$ & & & 110 & 71 & 117 & 4 & $366^{\circ}$ & 0 \\
\hline
\end{tabular}

1 Geologic source is questionable.

2 In solution at time of analysis.

${ }^{3}$ Analysis by Wyoming State Department of Agriculture, Laramie. Wyo.

${ }^{4}$ Riverton city well. 
$\mathrm{T}^{r}$ ind River Indian Reservation, $\mathrm{T}^{y} y o$-Continued

\begin{tabular}{|c|c|c|c|c|c|c|c|c|c|c|c|c|}
\hline \multirow[b]{2}{*}{$\begin{array}{l}\text { Sulfate } \\
\left(\mathrm{SO}_{4}\right)\end{array}$} & \multirow[b]{2}{*}{$\begin{array}{l}\text { Chlo- } \\
\text { ride } \\
\text { (Cl) }\end{array}$} & \multirow[b]{2}{*}{$\begin{array}{l}\text { Fluo- } \\
\text { ride } \\
\text { (F) }\end{array}$} & \multirow[b]{2}{*}{$\begin{array}{c}\mathrm{Ni}- \\
\text { trate } \\
\left(\mathrm{NO}_{3}\right)\end{array}$} & \multirow[b]{2}{*}{$\begin{array}{l}\text { Bo- } \\
\text { ron } \\
\text { (B) }\end{array}$} & \multirow{2}{*}{\multicolumn{2}{|c|}{\begin{tabular}{c|c}
$\begin{array}{c}\text { Dissolved } \\
\text { solids }\end{array}$ \\
$\begin{array}{c}\text { Resi- } \\
\text { due on } \\
\text { evapo- }\end{array}$ & Sum \\
ration & Sum
\end{tabular}}} & \multicolumn{2}{|c|}{$\begin{array}{l}\text { Hardness } \\
\text { as } \mathrm{CaCO}_{3}\end{array}$} & \multirow{2}{*}{$\begin{array}{l}\text { Sodi- } \\
\text { um-ad- } \\
\text { sorp- } \\
\text { tion- } \\
\text { ratio } \\
\text { (SAR) }\end{array}$} & \multirow{2}{*}{$\begin{array}{l}\text { Spe- } \\
\text { cific } \\
\text { con- } \\
\text { duct- } \\
\text { ance } \\
\text { (micro- } \\
\text { mhlos at } \\
25^{\circ} \mathrm{C} \text { ) }\end{array}$} & \multirow[b]{2}{*}{$\mathrm{pH}$} & \multirow[b]{2}{*}{ Remarks } \\
\hline & & & & & & & $\begin{array}{c}\text { Cal- } \\
\text { cium } \\
\text { mag- } \\
\text { nesi- } \\
\text { unl }\end{array}$ & $\begin{array}{l}\text { Non- } \\
\text { car- } \\
\text { bonl- } \\
\text { ate }\end{array}$ & & & & \\
\hline
\end{tabular}

\begin{tabular}{|c|c|c|c|c|c|c|c|c|c|c|c|c|}
\hline \multicolumn{13}{|c|}{ Alluvium of Little Wind River valley - Continued } \\
\hline 732 & 20 & 1.0 & 0.3 & 0.66 & 1,460 & 1,420 & 650 & 319 & 3.8 & 1,860 & $7.8^{\prime}$ & \\
\hline 63 & 5.7 & .3 & 1. 2 & .10 & 292 & 280 & 222 & $4^{2} 2$ & .4 & 476 & 7.6 & \\
\hline & $\ldots$ & .85 & & $\ldots \mid$ & 730 & (n..... & 340 & & & & 8.2 & \\
\hline$-\ldots$ & 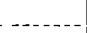 & .28 & $\ldots$ & $\ldots$ & $4: 20$ & $-\ldots$ & 209 & - & & & 7.9 & \\
\hline . & $\ldots$ & .95 & $\ldots$ & ...... & 540 & $-\ldots$ & 230 & - & & & 7. 8 & \\
\hline$-\ldots$ & $-\ldots$ & .9 & & 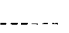 & 1,160 & $-\ldots$ & 655 & & & ..... & 7.8 & \\
\hline - n & $\ldots$ & .82 & -- & $\ldots$ & 550 & $\ldots$ & 347 & -.- & & & 7.4 & \\
\hline$\ldots$ & . & .58 & --1 & $\ldots$ & 1,160 & -...- & 525 & $\ldots$ & $\ldots$ & & 7.6 & \\
\hline$\ldots$ & $\ldots$ & .72 & & $\ldots .$. & 750 & $-\ldots$ & 275 & & & ....... & 7. $\bar{t}$ & \\
\hline 306 & 7. 2 & .5 & 3.4 & .96 & 72 & $75 \overline{7}$ & 173 & 0 & fi. 6 & 1,170 & 7.8 & $\operatorname{Mr} 0.16$ ppm. \\
\hline & $\ldots$ & .62 & 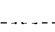 & $-\ldots$ & 930 & & 415 & & & & 7. 7 & \\
\hline$\ldots$ & n. & 1.32 & $\ldots$ & $\ldots$ & 450 & $\ldots$ & 195 & $\ldots$ & --- & $\ldots$ & 7.7 & \\
\hline 694 & 18 & .9 & 3.6 & .32 & $1, \mathbf{4 5 0}$ & 1,340 & 746 & $4 \div 2$ & 2.6 & 1,780 & 8.2 & \\
\hline 558 & 18 & .8 & 2.7 & .02 & 1,140 & 1,070 & 598 & 338 & 2. 2 & 1,480 & 7.9 & \\
\hline 845 & 13 & 1. 6 & 8.5 & .42 & 1,570 & $1,5 \geq 0$ & 641 & 421 & 3.9 & $1,930^{\circ}$ & 7.7 & \\
\hline 736 & 28 & .6 & 2.7 & .20 & 1,500 & 1,380 & 720 & 438 & 2. 9 & 1,810 & 8.1 & Mn 0.77 ppm. \\
\hline
\end{tabular}

Alluvium of Wind River valley - Continued

\begin{tabular}{|c|c|c|c|c|c|c|c|c|c|c|c|c|}
\hline 47 & 5.0 & 0.3 & 0.8 & 0.07 & 256 & 267 & 165 & 0 & 0.9 & 435 & 8.0 & \\
\hline 99 & $9 \quad$ & $\therefore 2$ & 10 & .04 & 354 & $-\ldots$ & 223 & $\ldots$ & .8 & 541 & 7.6 & \\
\hline 495 & 64 & .6 & $.1{ }^{\prime}$ & .17 & 1,270 & 1,230 & 456 & 56 & 4.9 & $1,790^{\prime}$ & 7.7 & Mn 0.20 ppm. \\
\hline 68 & 6.2 & .2 & .0 & .02 & 284 & 272 & 178 & 24 & .8 & 447 & 7.8 & \\
\hline 103 & 3.4 & .1 & 1. 4 & .06 & 378 & 397 & 286 & 51 & .6 & 635 & 7.6 & \\
\hline 80 & 7.4 & .2 & .0 & .05 & 392 & 355 & 272 & 57 & .5 & 603 & 8.0 & \\
\hline
\end{tabular}

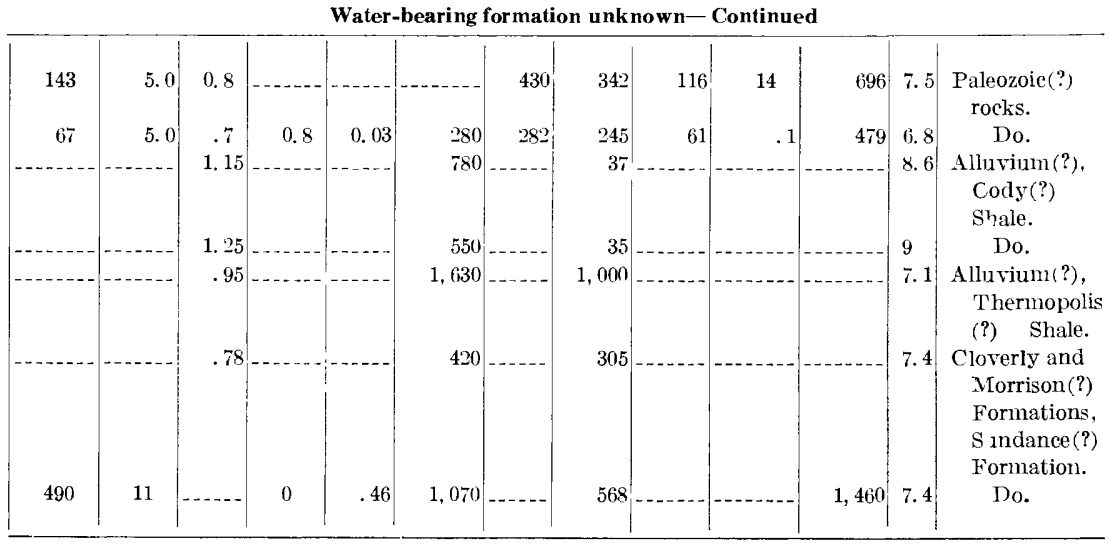


TaBue 7.-Chemical analyses

[Analytical results in parts pe* million, except as

Dis-
Date of collec- charge Silica Iron cium nesium un $\begin{gathered}\text { Cal- } \\ \text { Mag- Sodium }\end{gathered}$ bonate bonate Sulfate ride

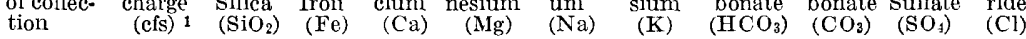

\section{INDIVIDUAL SAMPLES}

6-2185 2 Wind River near Dubois, Wyo.

1965

\begin{tabular}{|c|c|c|c|c|c|c|c|c|c|c|c|}
\hline July $19 \ldots \ldots$ & 632 & 20 & 0.11 & 13 & 1.9 & 2.9 & 1.5 & 57 & 0 & 0 & 0 \\
\hline Aug. $26 \ldots \ldots \ldots$ & 188 & 22 & 3.02 & 14 & 6.0 & 4. 5 & 1.8 & 78 & 0 & 2.5 & 1.1 \\
\hline Sept. 27 & 175 & 26 & .05 & 15 & 5.7 & 10 & 2.1 & 88 & 0 & 11 & 1.8 \\
\hline Nov. $1 \ldots . . . .$. & 87 & 24 & .05 & 22 & 5.5 & 6.7 & 2.2 & 101 & 0 & 8.2 & 0 \\
\hline Dee. $10 \ldots \ldots$ & 86 & 23 & .05 & 23 & 5. 7 & 7.4 & 2.6 & 102 & 2 & 17 & 0 \\
\hline \multicolumn{12}{|l|}{1966} \\
\hline Jan. $17 \ldots \ldots . . .$. & 63 & 27 & 3.00 & 23 & 7.4 & 9.0 & 2.5 & 113 & 0 & 13 & .7 \\
\hline Feb. $2 \ldots$ & 65 & 27 & .05 & 22 & 6.4 & 8.0 & 3.0 & 107 & 0 & 12 & 1. 1 \\
\hline Mar. 23. & 74 & 27 & .00 & 24 & 7.1 & 0.0 & 2.8 & 115 & 0 & 13 & 1. 1 \\
\hline Apr. 5.......... & 61 & 26 & .05 & 25 & 6.8 & 9.0 & 2.0 & 119 & 0 & 14 & 0 \\
\hline May $6 \ldots \ldots . . .$. & 368 & 17 & .19 & 13 & 7.2 & 7.0 & 2.5 & 67 & 0 & 14 & 5. 0 \\
\hline June $6 \ldots$ & 328 & 21 & $\ldots$ & 10 & 4. 9 & 6. 0 & 1.6 & 67 & 0 & 2.9 & 1. 1 \\
\hline July $5 \ldots$ & 230 & 23 & .10 & 16 & 3.2 & 7.3 & 1.9 & 71 & 0 & 6.4 & 0 \\
\hline Aug. $1 \ldots \ldots$ & 131 & 25 & .11 & 20 & 3.5 & 7.0 & 2.4 & 88 & 0 & 8.2 & .7 \\
\hline Sept. $6 \ldots \ldots$ & 84 & 24 & .15 & 21 & 6.7 & 7.9 & 1.5 & 95 & 0 & 14 & 3.5 \\
\hline Oet. $3 \ldots$ & 73 & 25 & .06 & 17 & 8.6 & 7. 7 & 1.5 & 110 & 0 & 6.6 & 4.3 \\
\hline
\end{tabular}

6-2310 2 Little Wind River above Arapahoe, Wyo.

1966

$\begin{array}{lllllllllllll}\text { Aug. 1. } 1 \ldots \ldots & 7.9 & 16 & 0.18 & 103 & 54 & 144 & 3.6 & 243 & 0 & 532 & 23\end{array}$

$\begin{array}{llllllllllll}\text { Sept. } 6 \ldots \ldots \ldots & 15 & 11 & .08 & 128 & 71 & 206 & 6.2 & 265 & 0 & 802 & 33\end{array}$

$\begin{array}{llrlllllllll}\text { Sept. } 30 \ldots \ldots & 36 & 9.6 & .11 & 100 & 43 & 131 & 2.4 & 244 & 0 & 447 & 25\end{array}$

6-2336 2 Pop Agie River at Hudson, Wyo.

1966

\begin{tabular}{|c|c|c|c|c|c|c|c|c|c|c|}
\hline Aug. 1....... & 73 & 12 & 0.18 & 103 & 43 & 71 & 3. 6 & 267 & 0 & 346 \\
\hline Sept. 6........ & 159 & 8.0 & .00 & 57 & 52 & 64 & 2.2 & 204 & 0 & 302 \\
\hline Sept. $30 \ldots$ & 123 & 5.4 & 3.04 & 80 & 37 & 64 & 2.4 & 210 & 0 & 305 \\
\hline
\end{tabular}

See footnotes at end of table. 
of surface-water samples

indicated. Analyses by U.S. Geological Surver]

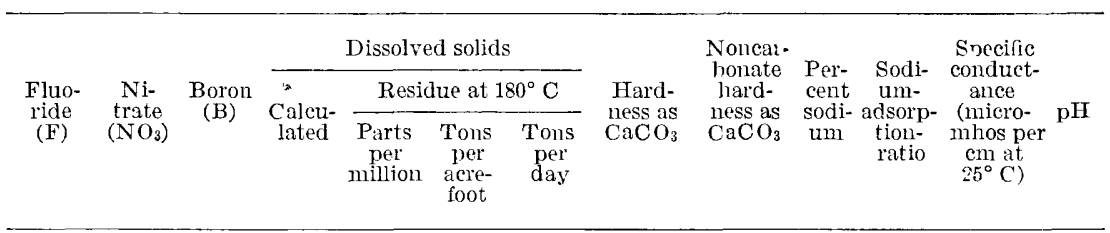

INDIVIDUAL SAMPLES-Continued

6-2185 2 Wind River near Dubois, Wyo.-Continued

\begin{tabular}{|c|c|c|c|c|c|}
\hline 0 & 0 & 0 & 67 & 72 & 0.10 \\
\hline .2 & .3 & 0 & 90 & 112 & .15 \\
\hline .1 & 0 & 0 & 115 & 102 & .14 \\
\hline .3 & .1 & 0 & 119 & 156 & .21 \\
\hline .2 & .1 & 0 & 133 & 172 & .23 \\
\hline
\end{tabular}

\begin{tabular}{|c|c|c|c|c|c|c|c|c|c|c|}
\hline .2 & 0 & 0 & 139 & 136 & $18 \ldots$ & 88 & 0 & 18 & .4 & 208 \\
\hline .2 & 0 & 0 & 133 & 142 & $.19 \ldots \ldots$ & 82 & 0 & 17 & .4 & 197 \\
\hline .2 & 0 & .04 & 141 & 164 & $.22 \ldots \ldots$ & 88 & 0 & 17 & .4 & $20 !$ \\
\hline .2 & 0 & .01 & 142 & 170 & $.23 \ldots \ldots$ & 90 & 0 & 17 & .4 & 236 \\
\hline 1 & .6 & 0 & 100 & 114 & $16 \ldots$ & 62 & 7 & 19 & .4 & 128 \\
\hline .2 & 0 & .02 & 81 & 100 & . $14 \ldots \ldots$ & 45 & 0 & 22 & .4 & 117 \\
\hline$\therefore$ & .3 & .01 & 93 & 34 & 13 & 52 & 0 & 23 & .4 & 133 \\
\hline .2 & .0 & 0 & 110 & 116 & $.16 \ldots \ldots$ & 65 & 0 & 18 & .4 & 157 \\
\hline .2 & .0 & .01 & 126 & 122 & $17 \ldots \ldots$ & 81 & 3 & 17 & .4 & 171 \\
\hline .2 & .3 & .02 & 125 & 122 & $.17 \ldots \ldots$ & 78 & 0 & 17 & .4 & 185 \\
\hline
\end{tabular}

6--2310 2 Little Wind River above Arapahoe, Wyo.-Continued

$\begin{array}{rrrrrrrrrrrr}0.9 & 2.1 & 0.19 & 9.19 & 1,050 & 1.43 \ldots \ldots \ldots & 478 & 279 & 39 & 1.9 & 1,400 & 7.8 \\ .9 & .0 & .24 & 1,390 & 1,420 & 1.913 \ldots \ldots \ldots & 610 & 393 & 42 & 3.6 & 1,810 & 8.0 \\ .7 & 1.9 & .16 & 881 & 924 & 1.26 \ldots \ldots \ldots & 425 & 225 & 40 & 2.7 & 1,260 & 8.0\end{array}$

6-2336 2 Pop Agie River at Hudson, Wyo.-Continued

$\begin{array}{rrrrrrrrrrrr}0.6 & 0.9 & 0.12 & 718 & 764 & 1.04 \ldots \ldots \ldots & 435 & 216 & 26 & 1.5 & 1,050 & 7.6 \\ .5 & .0 & .00 & 593 & 662 & .60 \ldots \ldots \ldots & 356 & 189 & 28 & 1.5 & 881 & 7.7 \\ .5 & .0 & .13 & 606 & 638 & .87 \ldots \ldots \ldots \ldots & 350 & 178 & 28 & 1.5 & 900 & 8.1\end{array}$


TABLE 7.-Chemical analyscs of

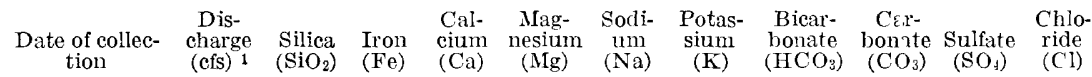

COMPOSITE SAMPLES

6-2280 2 Wind River at Riverton, Wyo.

1965

\begin{tabular}{|c|c|c|c|c|c|c|c|c|c|c|c|}
\hline Oct. $1-10$ & 768 & 18 & - - - & 33 & 8.3 & 19 & 2.3 & 135 & 0 & 46 & 5.7 \\
\hline Oct. $11-27 \ldots$ & 861 & 21 & - & 37 & 10 & 20 & 2.9 & 156 & 0 & 51 & 3.5 \\
\hline Oct. 28-Nov. 3.. & 1,460 & 10 & - & 31 & 13 & 17 & 2.0 & 113 & 0 & 71 & 5.3 \\
\hline Nov. 4-16..... & 529 & 14 & $---\infty$ & 44 & 16 & 24 & 2.8 & 165 & 0 & 88 & 5.3 \\
\hline Nov. 17-30..... & 506 & 17 & $-\ldots-n$ & 44 & 15 & 23 & 2.8 & 186 & 0 & 71 & 7.1 \\
\hline Dec. $1-9 \ldots$ & 479 & $10^{\circ}$ & -..-- & 45 & 16 & 25 & 2.9 & 192 & 0 & 71 & 5.3 \\
\hline Dec. $10-18 \ldots \ldots$ & 417 & 15 & - - & 49 & 19 & 28 & 2.9 & 195 & 0 & 103 & 5.3 \\
\hline Dec. $19-31 \ldots$ & 395 & 15 & $-\cdots+-$ & 44 & 18 & 24 & 2.9 & 189 & 0 & 77 & 7.1 \\
\hline \multicolumn{12}{|l|}{1966} \\
\hline Jan. 1-15 & 438 & 16 & ---- & 47 & 12 & 24 & 3.5 & 183 & 0 & 56 & 5.3 \\
\hline Jan. 16-31 & 414 & 15 & $\ldots$ & 46 & 18 & 28 & 3.3 & 183 & 0 & 87 & 5.3 \\
\hline Feb. 1-12.... & 448 & 14 & $\ldots$ & 45 & 13 & 23 & 3.1 & 171 & 0 & 64 & 4. 3 \\
\hline Feb. $13-19 \ldots$ & 401 & 15 & $\ldots \ldots$ & 47 & 13 & 23 & 3.1 & 177 & 0 & 69 & 5.3 \\
\hline Feh. $20.28 \ldots$ & 474 & 15 & ----- & 44 & 13 & 24 & 3.1 & 168 & 0 & 67 & 3. 5 \\
\hline Mar. 1-13 _..... & 415 & 18 & $\ldots$ & 43 & 13 & 24 & 2.0 & 159 & 0 & 63 & 7.1 \\
\hline Mar. 14-31_..... & 376 & 15 & $\ldots$ & 43 & 13 & 32 & 2.0 & 171 & 0 & 76 & 7. 1 \\
\hline Apr. 1-7..... & 533 & 15 & $-\ldots-\ldots$ & 34 & 14 & 26 & 1.4 & 155 & 0 & 60 & 4. 6 \\
\hline Apr. 8-14 & 141 & 14 & $\ldots-\ldots$ & 48 & 17 & 43 & 1.5 & 186 & 0 & 114 & 5.3 \\
\hline Apr. $15-30 \ldots$ & 236 & 13 & $---\cdots$ & 37 & 16 & 33 & 1.0 & 165 & 0 & 82 & 4. 6 \\
\hline May $1-\tau_{-} \ldots \ldots$ & 341 & 19 & $\ldots \ldots$ & 40 & 13 & 24 & 2.5 & 165 & 0 & 68 & 3. 5 \\
\hline May 8-14 $\ldots . . .$. & 1,250 & 15 & $\ldots-\ldots$ & 24 & 8.9 & 12 & 1. 7 & 113 & 0 & 31 & 1. 8 \\
\hline May $15-31 \ldots$ & 246 & 15 & --- & 26 & 9.8 & 19 & 1.3 & 122 & 0 & 45 & 2.8 \\
\hline Jume $1-10 \ldots$ & 280 & 12 & --- & 28 & 6.0 & 22 & 1.5 & 107 & 0 & 52 & 2.5 \\
\hline June 11-19. .... & 246 & 13 & $\ldots$ & 30 & 6. 4 & 23 & 1.5 & 116 & 1 & 48 & 4.3 \\
\hline June $20-30 \ldots$ & 445 & 14 & $-\ldots-\ldots$ & 27 & 6.4 & 17 & 1.3 & 110 & 0 & 37 & 3.5 \\
\hline July $1-9 \ldots$ & 171 & 13 & $-\ldots-$ & 36 & 10 & 38 & 2.3 & 149 & 0 & 65 & 14 \\
\hline July 10-Aug. 9-- & 346 & 11 & 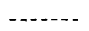 & 27 & 7.8 & 24 & 1.7 & 122 & 0 & 38 & 7.1 \\
\hline Aug. 10-Sept. 14_ & 190 & 10 & $\ldots-\cdots$ & 49 & 8.1 & 43 & 2.2 & 162 & 0 & 109 & 6. 7 \\
\hline Sept. $15-30 \ldots$ & 308 & 16 & ----- & 49 & 7.9 & 43 & 2.9 & 179 & 0 & 95 & 5.3 \\
\hline
\end{tabular}

See footnotes at end of table. 
TABLE 7.-Chemical analyses of

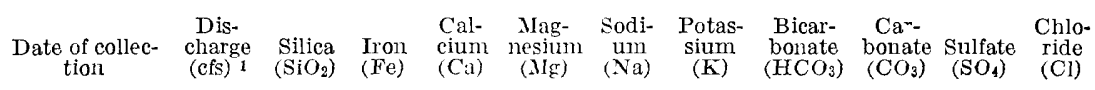

6-2355 ${ }^{2}$ Little Wind River near Riverton, Wyo.

1965

\begin{tabular}{|c|c|c|c|c|c|c|c|c|c|c|c|}
\hline Oct. $1-20$ & 503 & 8.5 & -.... & 62 & 31 & 50 & 2.8 & 159 & 0 & 249 & 9.9 \\
\hline Oct. 21-31 $\ldots$ & 387 & 6.3 & 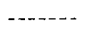 & 63 & 35 & 48 & 2.9 & 171 & 0 & 253 & 8.5 \\
\hline Nov. 1-15_... & 338 & 5.5 & $\ldots \ldots$ & 74 & 33 & 55 & 3.5 & 190 & 0 & 259 & 9.9 \\
\hline Nov. $16-30 \ldots$ & 301 & 7. 2 & $-\cdots+n$ & 78 & 36 & 59 & 3. 6 & 196 & 0 & 293 & 10 \\
\hline Dec. 1-13 _.... & 222 & 8.7 & ----+ & 69 & 37 & 55 & 3.1 & 186 & 0 & 267 & 8.9 \\
\hline Dec. 14-18 & 197 & 10 & $--\infty-\infty$ & 76 & 36 & 66 & 3.8 & 210 & 0 & 283 & 11 \\
\hline Dec. $19-31 \ldots$ & 234 & 12 & 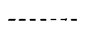 & 74 & 39 & 61 & 3.2 & 210 & 0 & 291 & 8.9 \\
\hline \multicolumn{12}{|l|}{1966} \\
\hline Jan. 1-10..... & 233 & 11 & --n- & 68 & 38 & 58 & 3.3 & 192 & 0 & 274 & 11 \\
\hline Jan. 11-27...... & 198 & 12 & 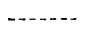 & 73 & 32 & 52 & 3.0 & 192 & 0 & 249 & 11 \\
\hline Jan. 28-Feb. 5_- & 193 & 11 & ------ & 70 & 29 & 47 & 3.5 & 186 & 0 & 218 & 8.9 \\
\hline Feb. $2-20 \ldots$ & 189 & 11 & -....- & 76 & 35 & 56 & 3.2 & 198 & 0 & 260 & 11 \\
\hline Feb. 21-28 & 214 & 11 & ----- & 76 & 32 & 54 & 3.5 & 186 & 0 & 255 & 12 \\
\hline Mar. 1-10 _ _...- & 198 & 11 & $-\cdots--$ & 76 & 38 & 62 & 2.5 & 186 & 0 & 294 & 16 \\
\hline Mar. 11-18_-_-- & 272 & 12 & $-\cdots--$ & 78 & 49 & 110 & 5.5 & 165 & 0 & 455 & 18 \\
\hline Mar. 19-31...... & 264 & 11 & 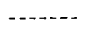 & 80 & 45 & 79 & 3.5 & 189 & 0 & 361 & 16 \\
\hline Apr. 1-16...... & 298 & 11 & --- - - & 75 & 33 & 68 & 4. 0 & 188 & 0 & 294 & 18 \\
\hline Apr. $17-30 \ldots$. & 304 & 9.2 & $\ldots \ldots$ & 85 & 47 & 116 & 4. 0 & 198 & 0 & 463 & 19 \\
\hline May 1-7_.....- & 337 & 7.2 & $\ldots---$ & 61 & 27 & 54 & 1. 4 & 162 & 0 & 230 & 13 \\
\hline May 8-15_...-. & 805 & 7.8 & $\rightarrow-\cdots$ & 42 & 12 & 30 & 1.0 & 116 & 0 & 116 & 6.4 \\
\hline May $16-31 \ldots$ & 475 & 4.8 & 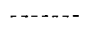 & 46 & 16 & 33 & 1.1 & 133 & 0 & 138 & 6. 7 \\
\hline June 1-10 & 612 & 8.5 & $-\cdots-$ & 54 & 18 & 41 & .6 & 128 & 0 & 183 & 7.1 \\
\hline June $11-30 \ldots$ & 659 & 8.0 & $\ldots \ldots$ & 54 & 23 & 40 & 1.5 & 134 & 0 & 186 & 7.1 \\
\hline July $1-15 \ldots$ & 297 & 8.8 & $\rightarrow-\infty$ & 77 & 33 & 68 & 1.4 & 192 & 6 & 289 & 11 \\
\hline July $16-31 \ldots$ & 115 & 12 & $\ldots \ldots$ & 95 & 37 & 94 & 2.0 & 222 & 0 & 384 & 16 \\
\hline Aug. 1-20 & 102 & 12 & $\cdots+$ & 99 & 42 & 99 & 3.0 & 238 & 0 & 411 & 17 \\
\hline Aug. 21-Sept. $10_{-}$ & 182 & 9.2 & $---\infty$ & 98 & 40 & 95 & 2. 6 & 226 & 0 & 397 & 15 \\
\hline Sept. 11-30 & 219 & 8.9 & $-\ldots-$ & 90 & 36 & 89 & 2.7 & 203 & 0 & 363 & 17 \\
\hline
\end{tabular}

1 Discharge subject to revision.

2 Official station number.

${ }^{3}$ In solution at time of analysis. 


\begin{tabular}{|c|c|c|c|c|c|c|c|c|c|c|c|c|}
\hline \multirow{3}{*}{$\begin{array}{l}\text { Fluo- } \\
\text { ride } \\
\text { (F) }\end{array}$} & \multirow{3}{*}{$\begin{array}{c}\mathrm{Ni}- \\
\text { trate } \\
\left(\mathrm{NO}_{3}\right)\end{array}$} & \multirow{3}{*}{$\begin{array}{c}\text { Boron } \\
\text { (B) }\end{array}$} & \multicolumn{4}{|c|}{ Dissolved solids } & \multirow{3}{*}{$\begin{array}{l}\text { Hard- } \\
\text { nrss as } \\
\mathrm{CaCO}_{3}\end{array}$} & \multirow{3}{*}{$\begin{array}{c}\text { Noncar- } \\
\text { bonate } \\
\text { hard- } \\
\text { ness as } \\
\mathrm{CaCO}_{3}\end{array}$} & \multirow{3}{*}{\multicolumn{3}{|c|}{$\begin{array}{lc}\text { dsorp- (micro- } \\
\text { tion- mhos per } \\
\text { ratio } & \mathrm{cm} \mathrm{at} \\
& \left.25^{\circ} \mathrm{C}\right)\end{array}$}} & \multirow{3}{*}{$\mathrm{pH}$} \\
\hline & & & \multirow{2}{*}{$\begin{array}{l}\text { Calcu- } \\
\text { lated }\end{array}$} & \multicolumn{3}{|c|}{ Residue at $180^{\circ} \mathrm{C}$} & & & & & & \\
\hline & & & & $\begin{array}{l}\text { Parts } \\
\text { per } \\
\text { million }\end{array}$ & $\begin{array}{l}\text { Tons } \\
\text { per } \\
\text { acre- } \\
\text { foot }\end{array}$ & $\begin{array}{l}\text { Tons } \\
\text { per } \\
\text { day }\end{array}$ & & & & & & \\
\hline
\end{tabular}

6-2355 2 Little Wind River near Riverton, Wyo.-Continued

\begin{tabular}{|c|c|c|c|c|c|c|c|c|c|c|c|c|}
\hline 0.6 & 0.0 & 0.12 & 493 & 544 & 0.74 & 738 & 284 & 154 & 27 & 1.3 & 743 & 8. 0 \\
\hline .4 & .7 & .09 & 502 & 500 & .68 & 522 & 301 & 161 & 26 & 1. 2 & 762 & 8.2 \\
\hline .7 & .2 & .10 & 534 & 572 & .78 & 523 & 320 & 164 & 27 & 1. 3 & 800 & 7.9 \\
\hline .7 & .6 & .11 & 584 & 602 & .82 & 490 & 340 & 179 & 27 & 1.4 & 862 & 7.9 \\
\hline .5 & .0 & .10 & 534 & 570 & .78 & 343 & 322 & 169 & 27 & 1.3 & 836 & 7.8 \\
\hline .5 & .1 & .11 & 589 & 628 & .85 & 332 & 340 & 168 & 29 & 1. 6 & 897 & 7. 9 \\
\hline .5 & .2 & .10 & 594 & 624 & .85 & 395 & 344 & 172 & 28 & 1.4 & 874 & 7.8 \\
\hline .5 & 1.4 & .04 & 559 & 600 & .82 & 379 & 328 & 171 & 28 & 1.4 & 838 & 8.0 \\
\hline .5 & 1.0 & .00 & 528 & 544 & .74 & 291 & 312 & 155 & 26 & 1. 3 & 804 & 8.0 \\
\hline .5 & 1.1 & .10 & 480 & 502 & .68 & 260 & 295 & 142 & 25 & 1.2 & 754 & 7.9 \\
\hline .5 & 1. 1 & .11 & 551 & 582 & .79 & 296 & 331 & 169 & 27 & 1. 3 & 844 & 7.7 \\
\hline .5 & 2.0 & .10 & 537 & 564 & .77 & 327 & 320 & 168 & 27 & 1.3 & 825 & 7.8 \\
\hline .5 & 1.1 & .09 & 592 & 634 & .86 & 338 & 345 & 193 & 28 & 1.5 & 894 & 8.0 \\
\hline .5 & 8.2 & .11 & 817 & 874 & 1.19 & 642 & 396 & 261 & 37 & 2.4 & 1.180 & 7.8 \\
\hline .5 & 1.8 & .10 & 691 & 762 & 1.04 & 545 & 386 & 231 & 31 & 1.7 & 1,040 & 8.0 \\
\hline 1.0 & .0 & .06 & 590 & 604 & .82 & 485 & 323 & 169 & 31 & 1.6 & $8 i^{2}$ & 8.0 \\
\hline .7 & 2.5 & .08 & 843 & 872 & 1.19 & 718 & 405 & 243 & 38 & 2.5 & 1,180 & 8.0 \\
\hline .5 & .1 & .03 & 474 & 498 & .68 & 455 & 265 & 132 & 31 & 1.4 & 726 & 7.3 \\
\hline .3 & .1 & .05 & 273 & 390 & .39 & 623 & 156 & 61 & 29 & 1. 0 & 445 & 7.5 \\
\hline .3 & .1 & .04 & 307 & 340 & .46 & 433 & 181 & 80 & 28 & 1.1 & 509 & 7.3 \\
\hline .3 & .9 & .07 & 376 & 394 & .54 & 655 & 208 & 103 & 30 & 1.2 & 588 & 7.0 \\
\hline .3 & .5 & .10 & 386 & 406 & .55 & 719 & 228 & 118 & $2 \vec{\imath}$ & 1.1 & 604 & 6.9 \\
\hline .5 & .8 & .12 & 590 & 616 & .84 & 495 & 330 & 163 & 31 & 1. 6 & 876 & 8.3 \\
\hline .6 & .8 & .14 & 751 & 780 & 1.06 & 242 & 390 & 208 & 34 & 2.0 & 1,090 & 8.0 \\
\hline 6 & .5 & .18 & 801 & 842 & 1.15 & 233 & 420 & 223 & 34 & 2.1 & 1,100 & 8. 2 \\
\hline .6 & .5 & .20 & 769 & 716 & .97 & 350 & 410 & 225 & 33 & 2.0 & 1,070 & 8.1 \\
\hline .6 & .6 & .18 & 708 & 748 & 1.02 & 443 & 372 & 206 & 34 & 2.0 & 997 & 8.2 \\
\hline
\end{tabular}




\section{INDEX}

[Italic page numbers indicate major references]

A

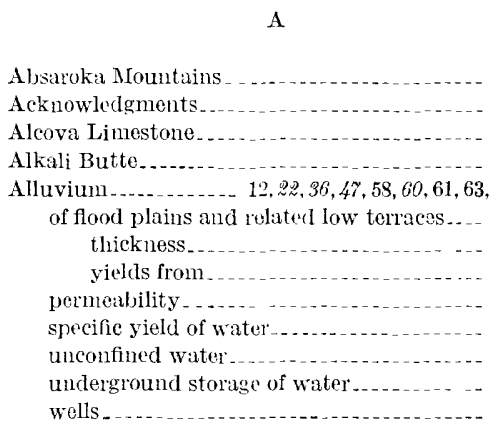

Altitudes

Amsden Formation..

Aquifer characteristies.

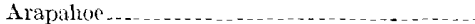

Arapalioe area...... _...

Arapahoe Indians ..........................

Artesian water. . . . . . . . . . . . . . . . . . . .

Aycross Formation.

\section{$\mathrm{B}$}

Beatl and others, cited

Beaver Creek valley

36,47

Bighorn Basin

Bighonn Dolomite

Biehorn River.

Boysen Reservoir.

Burris

\begin{tabular}{r|} 
Page \\
I 8 \\
4 \\
18 \\
41.42 \\
6.4 .67 \\
19 \\
49 \\
49 \\
68 \\
67 \\
23 \\
66 \\
68 \\
8 \\
19 \\
23 \\
54,63 \\
11 \\
9 \\
64 \\
14,46 \\
\hline
\end{tabular}

\section{(1)} D $\begin{array}{lr}\text { D } & \text { Page } \\ \text { Darby Formation } & \text { I 19,39 } \\ \text { Darwin Sandstone Wember. } & 19 \\ \text { Dinwoody Formation } & 18 \\ \text { Discharge of ground water. } & 12 \\ \text { Dissolved solids in water: } & \end{array}$

Aycross. Tepee Trail, and Wiggins Fornations - ............. alluvium of flood plains and ro'ated low terraces.................... 49

alluvium in stream valleys ........... 47

Fivenile Creek_......................... 55

Fort Union Formation .......... 48

Indian Meudows Formation._......... 42

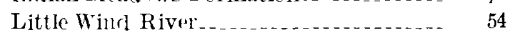

Lower Ifsozoic rocks................ 49

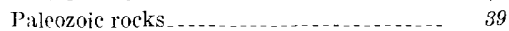

Preambrian rocks_._._._. 38

terraces and pediment deposits....... $46^{2}$

upper Meserzoic rocks................. $4 t$

Wint River.............................. 54

Wind River Formation _......... 45

rainage........ 8

Drainage, methods tor improving ........... 57 ,

$59,60,61,62,63,64,65$

classification and evaluation _.......... 58

in underfit stream valleys........... 63

Coolider System, Little Wind nuit _.- 65

Ray System, Littlo Wind unit...... 64

in Wind Rivis Irrigation Project _....... 56

oll flood plains _....... 58

Coolige system, Little Wind unit..... 61

Jolnstown unit ................. 59

Loft-Hand unit........ 58

Sub-Agercy System, Little Wind unit ... 61

Lprer Wind unit .

on teriaces _.

Ray System, Little Wind unit ....... 63

Sul-Agency System, Little Wind unit _ $\quad 63$

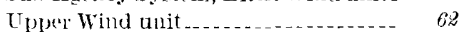

outsike Wind River Irrigation Project... 56

slopes _... 6.5

Draintage problems, mothods for reduring ... $66^{\circ}$

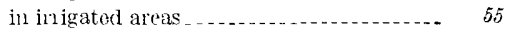

transitional areas..... 66

J rainage studies, previous

Dry Creek . . . 63

Dubois ............ 49,54

E

Cottonwood Creek _.......

Crow Creek valley _._._._._._._._._._._._. 49

Crow Mountain Sandstone $\ldots \ldots \ldots$ 18, 40

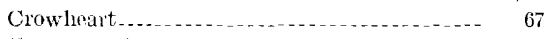

Crowheart terace $\ldots \ldots \ldots \ldots 2,63$

Eaton, F. M., cited _................... 51

Ethete _...... 11,61,67

Etlete area $\ldots \ldots \ldots \ldots$ 
Fieldwork

Fivemile Creek drainage $\ldots \ldots$

Fivemile valley . ........................... 36

Flathead Sandstone.................. 20

Flood plains, drainage-problem areas....... 58

Fort Union Formation.

thickness............................. 41

yields of water . ..................... 42

Fort Washakie _....... 11,37

Frontier Formation.

G

Gallatin Limestone .

Geographic setting .

Geologic map

Geologic setting .............

Geologic units and potential water supply....

Geologic units in relation to ground water.... 35,64

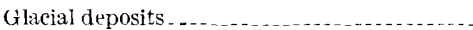

Gros Ventre Formation.... . . . . . . . .

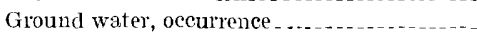
quality

Gypsum Spring Formation

$\mathrm{H}$

Hardness in water, defined

History of irrigation.

Hudson.

Hydrographs of water-level fluctuations

Page

Ickee, J. E., cited _......................... 51,54

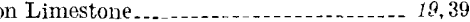

Meeteetse Formation . ................... 16,41

Mesaverde Formation . .................. 16,41

Mesozoic rocks, lower.................. $\quad 39$

lower, yields of water................... 40

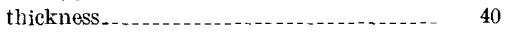

upper......... 40

yields of water....... 41

Mill Creek

Mill Creek School_...

Mill Creek valley $\ldots \ldots \ldots \ldots 2,63,65,67$

Morrison Formation.................... 17, 41

Mowry Shale_._.

Nuddy Creek . . . .

Muddy Creek valley ....................... 36

North South Fork Little Wind River........ 64

Nugget Sandstone...................... 17,40

Oil fields. . . . _.

Other Tertiary rocks, thickness _....._._. 46

yields from

Owl Creek Irrigation District............. 56

Owl Creek Mountains _..._._._._._. 8, 9, 38, 39,40,41

Owl Creek valley ........... $10,49,55,66$

Ownership of land............. 9

\section{I}

Indiau Meadows Formation thickness...

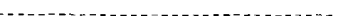
yields from chemical character of water

classification of water.

history

quality of water in alluvium

\section{$\mathrm{J}, \mathrm{K}$}

Johnson, E. E., Inc., cited

Johnstown canal . . . . . . . . . . . . . . . . . Johnstown unit, drainag s-probjem areas _..... Kirl,y Draw valley

\section{L}

Lance(?) Formation.

15,41

Lander.

Landslide and steep-slope colluvial deposit..

Laramide deformation.

Left-Hand Canal.

Left-Hand unit, drainage-problem arass

Little Wind River. $8,11,45,55,62,64,66$

Little Wind River valley. 37,63

Location and extent of area

Lower Eocene Wind River Tormation

Lowry, M. E., cited.

\section{$\mathrm{P}$}

leozoic rocks

gases and oil in water............ 39

thickness.

Pavillion _._._. 11

Permian rocks............ 18

Physiography ........................... 8

Popo Agie Formation

Popo Agie River.

Population .... 9

Potential use of underground storage . . ....... 66

Precambrian rocks . . . 38

dissolved solids in

65 Present development of ground water . . . . 10

Previous investigations.................. 4

Pumping tests, wells in alluvium ......... 30,36

Wind River Fornation............ 27

Purpose of investigation................. 2

Quality of ground water.

Quality of surface water. ................... 54

Quaternary age, unconfined water in alluvium....... 23

Quaternary rocks

Ray system, Little Wind unit, drainage-prob-

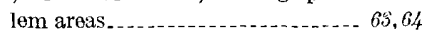

Recharge of ground water ..............

Records of wells and springs.............. 72

Red Peak Formation

Riverton._._.

Riverton Irrigation Project__._._._. 4, 9, 10,54,55

11 Riverton-Le Clair Irrigation District . . . _ _ 55,56

39 Riverton well field _.......... 12, 23,98,45 
Sampling stations .

Scotield, C. S., cited .

Scope of investigation supply

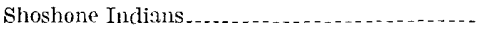

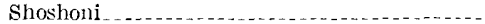

Shotgun Butte . . .

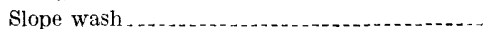

Slope wash and alluvium, thickness. ....... yiclds from

Slopes, drainace-problem areas.

South Fork Little Wind River............. 11,64

Specific-capacity data, wells in alluvium...... wells in Wind River Formation

Specific yield of water in alluvium.......... springs, records

Stratigrapliy

Structural basin, downfolded.

Sub-Ageney system, Little Wind unit, drainage-problem areas.

Summary _...

Sundance Formation _................... 1\%, 40

Surface water, quality................ 54

Susquehanna-Western, Inc................ $\quad 28$

$\mathrm{T}$

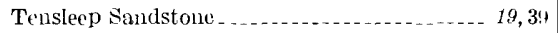

Tepee Trail Formation _................. 14,46

Terminology ..................... 5

Terrace and pediment deposits ............ 13,46

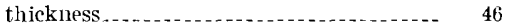

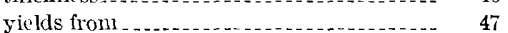

Terraces, drainage-problem areas _..._._... 62

Tertiary rocks...................................

Test drilling

3,58

Thermopolis Slrale. . .................... 17, 41

Travertine deposits _............... 13

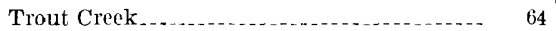

Trout Creek valley

\section{U}

Underint-stream valleys, drainage-problem

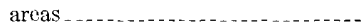

Upper Wind unit, drainage-problem areas _._. 60,62

U.S. Bur. of Indian Affairs, cited........ . 9, 58,66

U.S. Bur. of Reclamation, cited ............ 55

U.S. Public Health Service, quoted . . . . . . . .

U.S. Salinity Lab. Staff, cited
Washakie Mountains.

I 64

Water, yields, alluvium of flood plains and related low terraces............ 49

yields, Fort Union Formation............. 42

Indian Meadows Formation......... 42

lower Mesozoic rocks................ 40

other Tertiary rocks.................. 46

upper Mesozoic rocks . ............. 41

slope wash and alluvium ............ 47

terrace and pediment deposits....... 47

Wind River Fornation

Water-level fluctuations . ................... 22

Water levels, in rocks of Wind River Forniation. $\quad 22$

in wells . . . . .

Water-quality criteria, agricultural use ........ 51

domestic and numicipal use _............ 50

industrial use ............................. 54

Water-table fluctuations.................. 60

Water-supply potential, geologic units ....... 13

Well-numbering system . . . . .

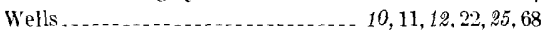

in alluvium, pumping tests_.......... 30,36

specifie-eapacity data.............. 37

in Wind River Formation............. 45

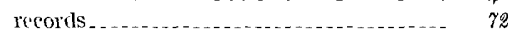

water levels . . . .

A1-1-34h, bh .... _.

A1-2-6aaa . .

A3-6-15bch _......................... 28

A1-4-31dec........ 87,59

B4-4-2cda . . .

B4-4-22al)a.......................... 37

D1-1-15ece. . . . .

D1-1-32dcb . .

D1-4-cdd . . .

D1-5-11ace......................... 28

Wiggins Formation .......... 13,46

Wind River _.

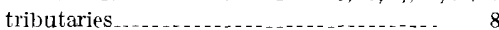

Wind River Basin................ 8, 39, 40

Wind River Formation ....... 12

$14,22,250,88,4^{2}, 44,59,60,61,62$ facies in permeability of water-hearing sandstonc. $\quad 68$

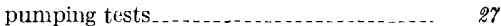
thickness water levels in rocks ................ 22 wells specific-capacity data.............. 39 yields of water . . . . . . . . . . . . . . . 45

Wind River Mountains ... $8,9,11,36,38,39,40,41,46$ Wind River valley . . .

50 Wolf, H. W., cited ....... 51,54

52 Wyoming No. 2 canal .................... 55 


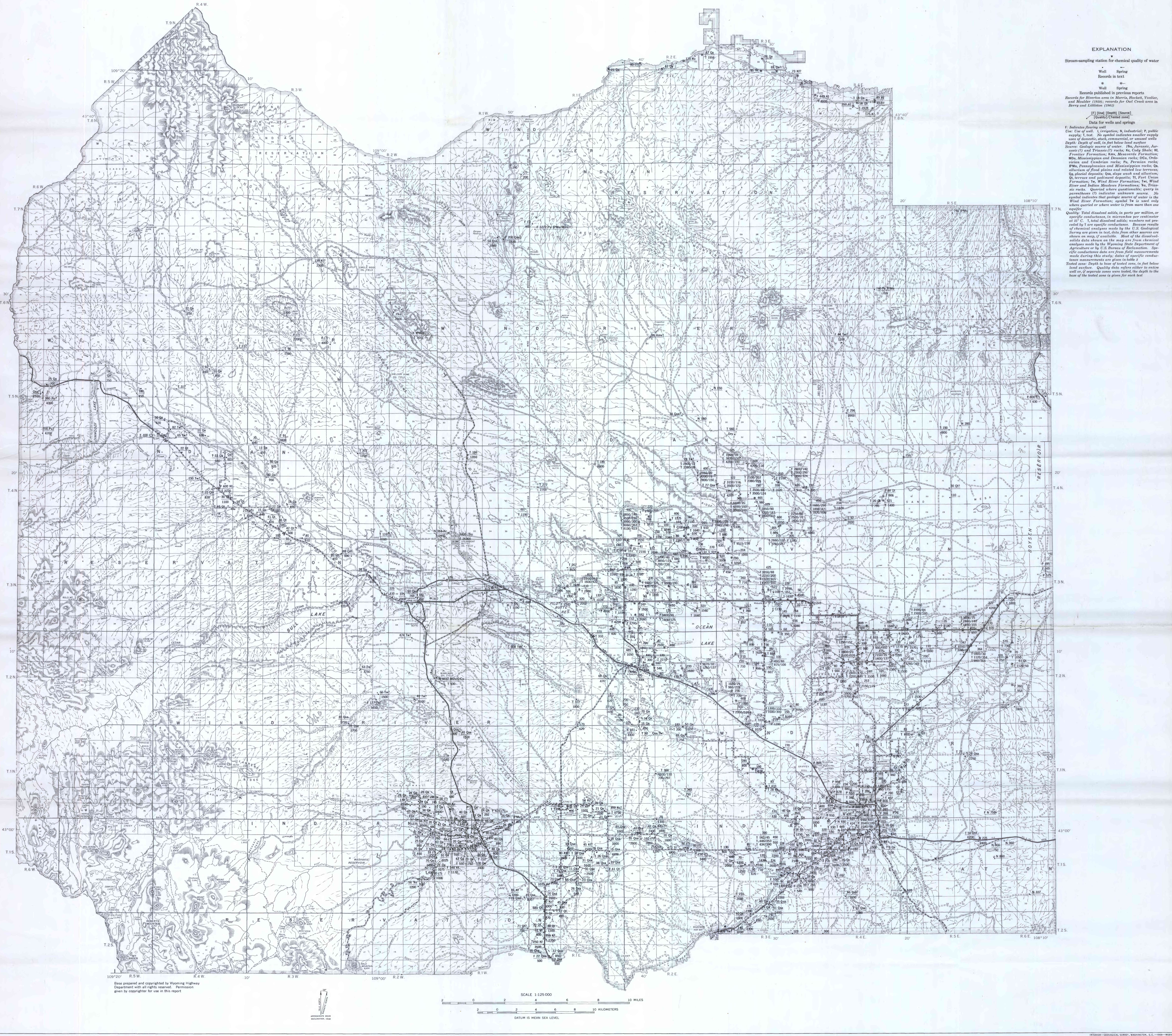



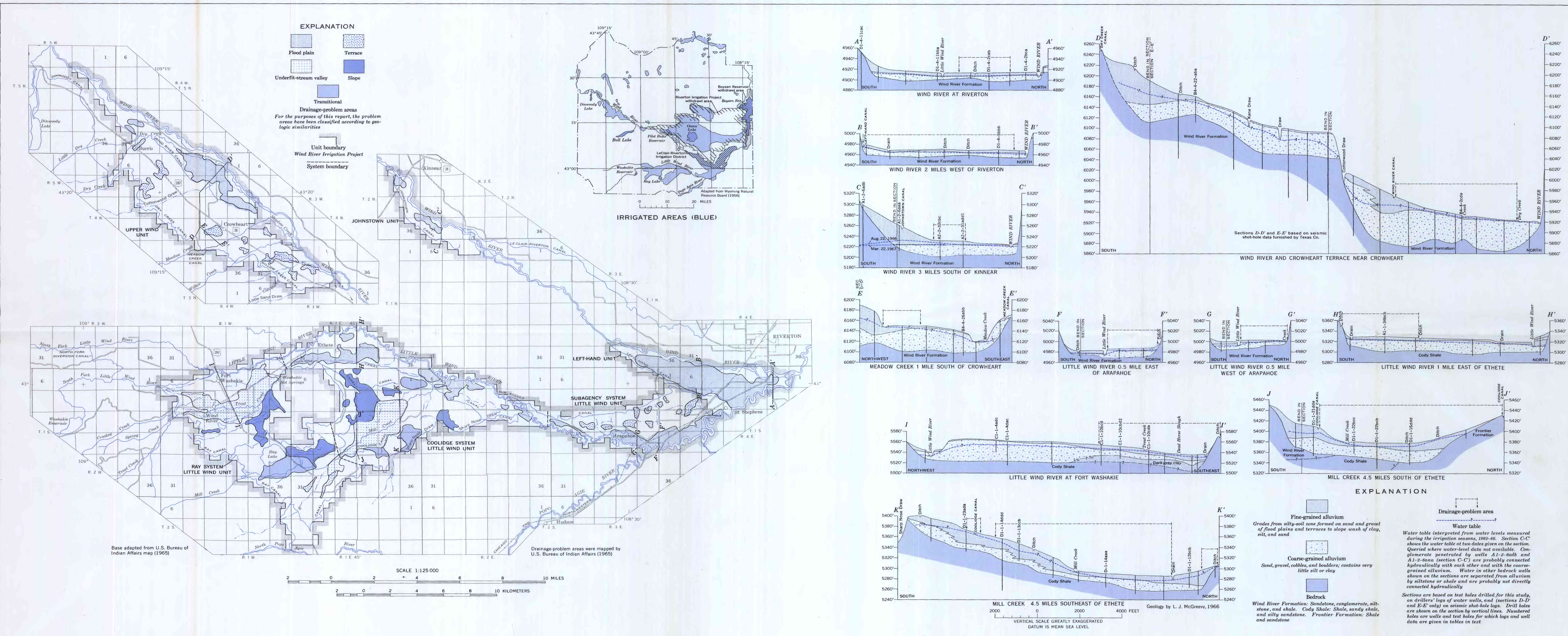

MAP AND SECTIONS SHOWING DRAINAGE-PROBLEM AREAS IN THE WIND RIVER IRRIGATION PROJECT, WIND RIVER INDIAN RESERVATION, WYOMING 